\title{
ileel EDVFU
}

\section{Letras \& Letras}

O Pirotécnico Murilo Rubião

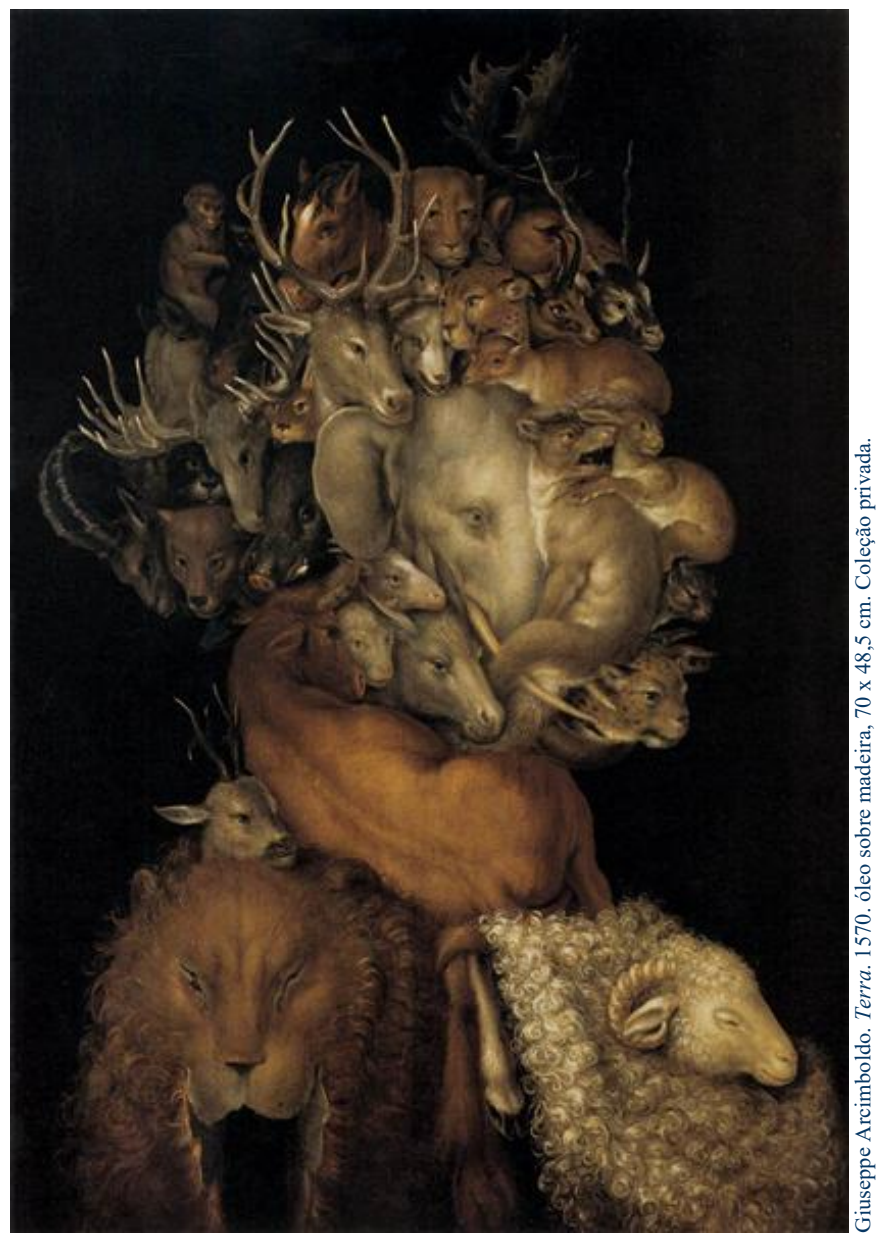

Organização:

Profa. Dra. Marisa Martins Gama-Khalil

Profa. Dra. Maria João Simões

Profa. Dra. Adelaide Caramuru Cezar

$2^{\circ}$ Semestre 2018

Volume 34, número 2

ISSN:1981-5239 


\title{
Expediente
}

\section{Universidade Federal de Uberlândia}

\author{
Reitor \\ Prof. Valder Steffen Júnior \\ Vice-Reitor \\ Prof. Orlando César Mantese \\ Diretor da EDUFU \\ Prof. Guilherme Fromm \\ Diretor do Instituto de Letras e Linguística \\ Prof. Ariel Novodvorski
}

\begin{abstract}
EDUFU - Editora e Livraria da Universidade Federal de Uberlândia Av. João Naves de Ávila, 2121 - Bloco 1S - Térreo - Campus Santa Mônica

CEP: 38.408-144 - Uberlândia - MG

Telefax: (34) 3239-4293

E-mail:vendas@edufu.ufu.br|www.edufu.ufu.br
\end{abstract}

\section{Editoração: Prof. Igor A. Lourenço da Silva}

Dados Internacionais de Catalogação na Publicação (CIP)

Sistema de Bibliotecas da UFU, MG, Brasil.

\footnotetext{
Letras \& Letras, v. 34, n. 2, jul/dez 2018, Uberlândia,

Universidade Federal de Uberlândia, Instituto de Letras e Linguística, 1985-

Semestral.

Modo de acesso: http://www.seer.ufu.br/index.php/letraseletras

Editoração: Igor A. Lourenço da Silva.

Organização: Marisa Martins Gama-Khalil, Maria João Simões,

Adelaide Caramuru Cezar.

Diagramação: Igor A. Lourenço da Silva.

Revisão Inglês: Igor A. Lourenço da Silva.

ISSN: 1981-5239

1. Língua. 2. Literatura-Crítica. 3. Linguística.

1. Universidade Federal de Uberlândia. Instituto de Letras e Linguística.
}

CDU: 801(05)

Todos os artigos desta revista são de inteira responsabilidade de seus autores, não cabendo qualquer responsabilidade legal sobre seu conteúdo à Revista, ao Instituto de Letras e Linguística ou à Edufu. 


\section{Letras \& Letras}

\section{Diretor}

Igor A. Lourenço da Silva (UFU)

\section{Conselho Consultivo}

Israel de Sá (UFU)

Luisa Helena Finotti (UFU)

Carlos Augusto de Melo (UFU)

\section{Conselho Editorial}

Adriana Cristina Cristianini (UFU); Alceu Dias Lima (UNESP-CAr); Antônio Fernandes Júnior (CACUFG); Betina Rodrigues da Cunha (UFU); Carlos Augusto de Melo (UFU); Carlos Piovezani Filho (UNESP-CAr); Carmen Lúcia Hernandes Agustini (UFU); Cleudemar Alves Fernandes (UFU); Daniel Alves (UFPB); Dilma Maria de Mello (UFU); Douglas Altamiro Consolo (UNESP-IBILCE); Eduardo de Faria Coutinho (UFRJ); Elaine Cristina Cintra (UFU); Eliana Dias (UFU); Eliane Mara Silveira (UFU); Elisabeth Brait (PUC-SP); Elzimar Fernanda Nunes (UFU); Emília Mendes (UFMG); Enivalda Nunes Freitas e Souza (UFU); Ernesto Sérgio Bertoldo (UFU); Félix Bugueño Miranda (UFRGS); Fernanda Costas Ribas (UFU); Fernanda Mussalim G. L. Silveira (UFU); Flavio Benites (UFMS); Guilherme Fromm (UFU); Ida Lucia Machado (UFMG); Ingedore V. Koch (UNICAMP); Ismael Ângelo Cintra (UNESP-CAr); Ivã Carlos Lopes (UNESP - IBILCE); Ivan Marcos Ribeiro (UFU); Iza Quelhas (UERJ); Jair Tadeu da Fonseca (UFSC); Joana Luíza Muylaert de Araújo (UFU); João Antônio de Moraes (UFRJ/SJRP); João Bôsco Cabral dos Santos (UFU); Joaquim Alves de Aguiar (USP); John Milton (USP); José Guillermo Milan Ramos (UNINCOR); José Luiz Meurer (UFSC); José Olimpio Magalhães (UFMG); José Sueli de Magalhães (UFU); Juliana Santini (UNESP); Kênia Maria de Almeida Pereira (UFU); Krzysztof Migdalski (University of Wroclaw); Leila Bárbara (PUC-SP); Leonardo Francisco Soares (UFU); Luciana Borges (UFG); Luciana Moura Colucci de Camargo (UFTM); Luciene Almeida de Azevedo (UFBA); Luiz Carlos Travaglia (UFU); Luiz Gonzaga Marchezan (UNESP-CAr); Luzmara Curcino Ferreira (UNESP-CAr); Márcio Roberto Soares Dias (UESB); Marco Antônio Villarta-Neder (UNITAU); Margarita Correia (Universidade de Lisboa); Maria Aparecida Caltabiano M. B. da Silva (PUC-SP); Maria Aparecida Resende Ottoni (UFU); Maria Cecília de Lima (UFU); Maria das Graças Fonseca Andrade (UESB); Maria do Rosário Valencise Gregolin (UNESP-CAr); Maria Helena de Paula (UFG-CAC); Maria Imaculada Cavalcanti (UFG-CAC); Maria Inês de Almeida (UFMG); Maria Inês Vasconcelos Felice (UFU); Maria Ivonete Santos Silva (UFU); Maria José Rodrigues Faria Coracini (UNICAMP); Maria Luiza Braga (UFRJ); Maria Suzana Moreira do Carmo (UFU); Marisa Martins Gama-Khalil (UFU); Maura Alves de Freitas Rocha (UFU); Mike Scott (Universidade de Liverpool); Moacir Lopes de Camargos (UNIPAMPA); Nélia Scott (Universidade de Liverpool); Nilton Milanez (UESB); Orlando Nunes de Amorim (UNESP-IBILCE); Orlando Vian Júnior (UFRN); Oziris Borges Filho (UFTM); Paulo Fonseca Andrade (UFU); Rauer Ribeiro Rodrigues (UFMS); Regina Igel (University of Maryland College Park); Regma Santos (UFG/CA); Roberto Acízelo de Souza (UERJ); Roxane Helena Rodrigues Rojo (UFRJ); Sérgio Ifa (UFAL); Simone Azevedo Floripi (UFU); Simone Tiemi Hashiguti (UFU); Solange Fiuza Cardoso Yokozawa (UFG-CAC); Stéfano Paschoal (UFU); Susana Borneo Funk (UFSC); Suzi Frankl Sperber (UNICAMP); Tania R. S. Romero (UFLA); Valeska Souza (UFTM); Vera Follain de Figueiredo (PUC/RJ); Vera Lúcia Carvalho Casa Nova (UFMG); Walcir Cardoso (Concordia University); Waldenor Barros Moraes Filho (UFU); William Mineo Tagata (UFU). 
Participaram desta edição como pareceristas ad hoc:

João Carlos Biella

Julio França

Jurema José de Oliveira

Maria Celeste Tommasello Ramos

Maria Elisa Rodrigues Moreira

Regina da Costa Silveira

Regina Silva Michelli

Rita de Cássia Dionísio Santos

Rita de Cássia Silva Soares

Rosana Cristina Zanelatto Santos

Sonia Maria Gomes Sampaio 


\section{Sumário}

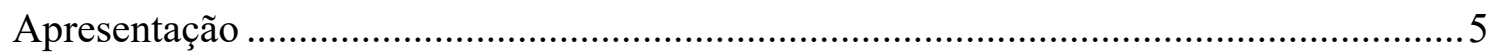

O pirotécnico Murilo Rubião: apontamentos introdutórios ...............................................

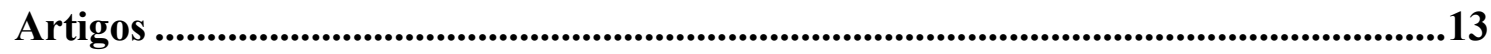

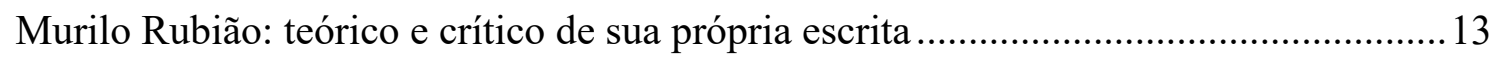

O processo criativo de Murilo Rubião: a busca do sentido perdido.................................. 32

"Petúnia", de Murilo Rubião, e o diálogo com os contos populares................................4 44

Histórias de uma fila: “A fila” (1974), de Murilo Rubião, e o Brasil dos anos de

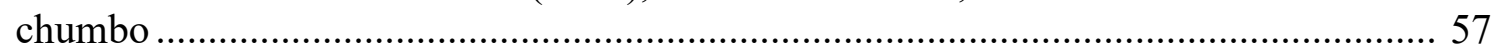

Armação de mundo possível e processos de composição de personagens insólitos em "O pirotécnico Zacarias”, de Murilo Rubião................................................................. 70

Sob os domínios do animal: um estudo do conto "Os dragões”, de Murilo Rubião ........91

Os lados do círculo em “Os três nomes de Godofredo”, de Murilo Rubião ................... 102

Os insólitos corpos de Murilo Rubião: uma leitura de "Bárbara" e "As unhas"............ 124

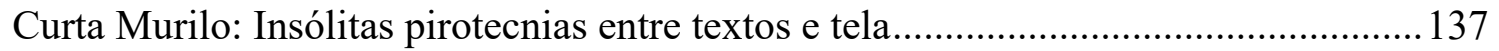

Murilo Rubião e José J. Veiga e a oposição ao racionalismo nos contos "O lodo" e "Os Cascamorros": breves considerações 


\title{
Apresentação
}

\section{O pirotécnico Murilo Rubião: apontamentos introdutórios}

\author{
Nessa hora os homens compreenderão que, mesmo à \\ margem da vida, ainda, vivo, porque a minha existência \\ se transmudou em cores e o branco já se aproxima da \\ terra para exclusiva ternura dos meus olhos. \\ (Murilo Rubião)
}

O fantástico instaura na ficção um efeito de estranheza que nos prende e nos desperta a curiosidade, instigando-nos à leitura ou à visão das imagens propostas na literatura, no cinema, nos filmes de animação, nas novelas gráficas e histórias em quadrinhos, enfim, em todo espaço estético no qual o insólito se planteia.

Porque procuramos e gostamos dessa estranheza? Como a recebemos e quais as emoções que nos desperta? Que tipo de emoções aqui se trata: reais, fingidas, imaginadas? Como se suscitam os efeitos de fantástico? Quais as estratégias acionadas para gerar o fantástico? Que estruturas e elementos fantásticos podemos reconhecer na ficção fantástica?

Essas são algumas de entre muitas outras perguntas que se poderiam levantar, as quais os investigadores e teóricos do fantástico tentam responder. E, como todo o fenômeno cultural é movente e dinâmico, também o fantástico vai procurando novas fórmulas e formas, tornando necessário não só procurar respostas, mas também ir levantando outras perguntas que se considerem pertinentes e possam contribuir para o estudo e o conhecimento do fantástico nas suas diferentes modalidades de apresentação.

O fantástico coloca em causa a forma convencional do nosso entendimento do espaço e do tempo, brinca com espaços irreais, joga com diferentes temporalidades, ativa conexões improváveis, propõe o impossível, ou seja, o fantástico vai para além dos limites do real, como ressalta David Roas (2011). Nesse sentido, quer a transgressão, quer a subversão constituem elementos basilares do fantástico, conduzindo o seu leitor a interrogar-se sobre o que conhece ou pensa.

Daí que esse teórico catalão, entre muitos outros, considere a transgressão um elemento fundacional do fantástico. Por seu turno, esse ingrediente conduz a um outro sentido que 
também é fundamental: o sentido subversivo. Ao colocar em causa uma lógica natural e ao sugerir nexos impensados, o fantástico obriga a repensar o conhecimento adquirido e convencional, introduz perplexidades e orienta para interrogações várias.

O conjunto de textos aqui reunidos pretende investigar alguns desses aspetos, aplicar conceitos e teorias à análise concreta de textos fantásticos e inferir sentidos relevantes a partir da interpretação de elementos e estratégias identificadas nos textos abordados. O foco de seleção do presente dossiê é a obra do escritor mineiro Murilo Rubião, cuja maestria das técnicas e estratégias ficcionais do insólito é sumamente reconhecida, fazendo com que a sua obra figure como referência para os críticos, os estudiosos e mesmos para os escritores de literatura fantástica.

O jornalista e contista Murilo Eugênio Rubião nasceu no primeiro dia de junho de 1916, em uma cidade situada no sul do Estado de Minas, naquela época chamada Silvestre Ferraz e hoje conhecida como Carmo de Minas. Em 1935 concluiu o Bacharelado em Humanidades, no Colégio Arnaldo, em Belo Horizonte, e em 1942, nessa mesma cidade, formou-se em Direito pela Universidade de Minas Gerais. É na capital de Minas Gerais que desenvolveu sua principal atividade remunerativa profissional, o jornalismo, tendo sido nomeado, em 1942, Diretor da Associação de Jornalistas Profissionais de Minas Gerais. Em relação às atividades desenvolvidas, ele relata: "Comecei a ganhar a vida cedo. Trabalhei em uma baleira, vendi livros científicos, fui professor, jornalista, diretor de jornal e de uma estação de rádio. Hoje sou funcionário público" (RUBIÃO, 2018). Na Espanha, em sua breve estadia, exerceu várias funções, como chefe do Escritório de Propaganda e Expansão Comercial do Brasil, adido junto à Embaixada Brasileira, membro da delegação brasileira no Congresso de Cooperação Intelectual. Em 1966 foi responsável pela criação do Suplemento literário de Minas Gerais, publicação de enorme relevo no campo da Literatura no Brasil. Essa publicação, que circula bimensalmente encartada nas edições do Jornal Minhas Gerais, da Imprensa Oficial, ficou famosa por ter desencadeado a "Geração Suplemento", que, ao longo da segunda metade do século XX, reuniu diversos autores nacionais e internacionais, como Luiz Vilela, Jaime Prado Gouvêa, Sérgio Sant'Anna, Bueno de Rivera, Fernando Sabino, Dalton Trevisan, Paulo Mendes Campos, Carlos Drummond de Andrade, Clarice Lispector, Júlio Cortázar e Jorge Luis Borges.

De todas as atividades exercidas por Murilo Rubião foi o ofício literário que o projetou como um dos maiores escritores do século XX na América Latina. Murilo Rubião pode ser considerado o precursor da tradição do insólito não só em terras brasileiras, como também merece reconhecimento como instigador da obra de escritores responsáveis pelo boom da literatura latino-americana, como confessa Julio Cortázar, conforme relato de Remy Gorga 
Filho (apud SILVEIRA, 2012): "Ele dizia que o mineiro Murilo Rubião foi o primeiro autor do fantástico latino-americano, antes mesmo dele, Cortázar".

No ano de seu falecimento, 1991, a Secretaria de Cultura de Belo Horizonte implantou o projeto Memória viva, destinado ao estudo e à divulgação de sua obra.

Seus contos foram traduzidos para várias línguas e frequentam editoras, bibliotecas e livrarias de vários espaços do mundo, como Estados Unidos, Tchecoslováquia, Espanha, Alemanha, Venezuela, França, Polônia, dentre outros.

Antonio Candido, um dos maiores nomes da crítica literária brasileira, ressalta, em "A nova narrativa", o valor da obra de Murilo Rubião no cenário da literatura no Brasil, porquanto esse autor mineiro conseguiu arquitetar contos insólitos em um momento estético "de predomínio do realismo social, propondo um caminho que poucos identificaram e só mais tarde outros seguiram" (CANDIDO, 2006, p. 252). Candido denomina como "ficção do insólito absurdo" a escrita muriliana. Em carta datada de 1967, Candido reitera o caráter precursor dos contos de Murilo Rubião e procura definir o efeito literário gerado pelo insólito ali instaurado: "um insólito despreocupado que suprime qualquer farol e nos faz sentir como se as leis do mundo estivessem normalmente refeitas. Uma naturalidade admirável, feita de supernaturalidade" (CANDIDO, 2018).

Como podemos compreender a configuração estética dessa categoria de insólito ("insólito absurdo") planteada por Candido sobre a obra de Rubião? Seguindo a compreensão empreendida por Gama-Khalil (2016) em "Murilo Rubião nos arredores do mito e do real maravilhoso", pautamo-nos, em primeiro lugar, pela noção de insólito acionada pela orientanda de Antonio Candido, Lenira Marques Covizzi, que defende a capacidade evidenciada pelo insólito de deflagrar, quer no plano da narrativa, quer no plano da recepção o "sentimento do inverossímel, incômodo, infame, incongruente, impossível, infinito, incorrigível, incrível, inaudito, inusitado, informal" (COVIZZI, 1978, p. 26 - ênfase da autora citada), uma vez que o insólito é potencializado por meio de um acontecimento que não sói ocorrer, não encontra, portanto, existência aparente no cotidiano prosaico. Para a compreensão da noção de "absurdo", Gama-Khalil aciona um diálogo com Albert Camus, em O mito de Sísifo, uma vez que, nesse livro, o absurdo é entendido como a "densidade e a estranheza do mundo", como "esse malestar diante da desumanidade do próprio mundo, essa incalculável queda diante da imagem daquilo que somos, essa 'náusea"' (CAMUS, 2013, p. 29). A junção das duas noções articuladas por Antonio Candido parece ser suficiente para explicar o grau de estranheza gerado pelos contos de Murilo Rubião: 
[...] o que o leitor encontra nesses contos é esse sentimento inusitado que advém de uma estranheza não especificamente do fantástico que surge nas narrativas, mas de perceber que esse inusitado, esse insólito, permeia o seu dia-a-dia aparentemente tão real, contudo ao mesmo tempo tão desumano e marcado por náuseas e estranhezas. (GAMA-KHALIL, 2016, p. 49)

Alguns críticos insinuam a influência de Franz Kafka sobre a escrita de Rubião, já que a escritura de Kafka também faz irromper o insólito em meio ao estupidamente prosaico. Contudo Murilo Rubião contesta, uma vez que teve o primeiro contato com a obra do escritor tcheco apenas em 1943, ano posterior à escrita da maior parte dos contos do livro $O$ ex-mágico. Afinal quem seria precursor de quem (suscitamos aqui um diálogo irônico com o ensaio de Borges)? Rubião fala-nos desses mágicos diálogos intertextuais em sua obra e na de Kafka:

Acredito que Kafka, como eu, tenha sido influenciado pelo Velho Testamento e pela mitologia grega. O que é a Metamorfose e Teleco senão a reinvenção do mito de Proteu, pastor do rebanho marinho de Netuno, que por detestar predizer o futuro, dom que lhe fora concedido, transforma-se em animais para não o fazer. (RUBIÃO, 1986, p. 4-5)

Ainda que muitos críticos não tenham afirmado sobre a influência de Kafka em sua ficção, quase todos reconhecem a afinidade das narrativas kafkianas com as murilianas, como é o caso de Mário de Andrade (In: MORAES, 1995, p. 32): “o mais estranho é o seu [de Murilo Rubião] dom forte de impor o caso irreal. O mesmo dom de um Kafka: a gente não se preocupa mais, e preso pelo conto, vai lendo e aceitando o irreal como si fosse real, sem nenhuma reação mais".

Murilo Rubião reconhece algumas importantes vertentes dialógicas de sua obra: "Minha opção pelo fantástico foi herança de infância, das intermináveis leituras de contos de fadas, do Dom Quixote, da História Sagrada e das Mil e Uma Noites”. (RUBIÃO, 1986, p. 4). Em todos esses livros Rubião encontrou elementos que o auxiliaram na elaboração estética do insólito em sua curta mas altamente significativa obra. São ao todo trinta e três contos considerados por ele "prontos" para a publicação; entretanto o seu labor ficcional consistia na incansável reescrita desses contos. Audemaro Taranto Goulart, autor de um dos ensaios deste dossiê, em seu livro O conto fantástico de Murilo Rubião, trata assim do processo de reescritura muriliano: "Tudo quanto se cria transforma-se em algo aberto, que está constantemente exigindo novas recriações" (GOULART, 1995, p. 16).

Davi Arrigucci Jr. (1987), em Enigma e comentário, traz a noção de experiência dos apontamentos teóricos de Walter Benjamin para analisar obras de vários escritores latino- 
americanos do século XX e dedica espaço privilegiado a reflexões sobre a escrita literária muriliana. Partindo do processo metamórfico de algumas de suas personagens (recordemo-nos, por exemplo, do emblemático Teleco), Arrigucci Jr. explica que as metamorfoses ocorrem na obra de Murilo Rubião não apenas no plano temático, mas ela acontece especialmente no plano da criação: uma escrita que é criada e recriada, assumindo novas facetas, inusitadas formas, metamorfoseando-se continuamente.

Sobre o processo metamórfico de sua escrita, Murilo Rubião assim se posiciona:

Sempre aceitei a literatura como uma maldição. Poucos momentos de real satisfação ela me deu. Somente quando estou criando uma história sinto prazer. Depois é essa tremenda luta com a palavra, é revirar o texto, elaborar e reelaborar, ir para a frente, voltar. Rasgar. (RUBIÃO apud GOULART, 1995, p. 16)

O movimento de ir, voltar e rasgar-se faz-nos lembrar do estilo defendido pelo defunto-autor Brás Cubas, criado por Machado de Assis, autor por quem Rubião nutria profunda admiração literária. Recordemos o estilo de Brás Cubas: "e este livro e o meu estilo são como os ébrios, guinam à direita e à esquerda" (ASSIS, 1985, p. 80).

Flávio Carneiro metaforiza o ato da reescrita por meio da imagem de uma "parede da finitude" e, nesse sentido, consegue explicar muito sobre a escritura muriliana:

Na obra de Murilo Rubião, a reescritura aparece como mais uma volta na espiral projetad pelo autor e reflete a capacidade do texto de se superar a cada linha, buscando o espaço que aparentemente se esconde atrás da parede da finitude. Reescrever é tentar de novo a derrubada dessa parede, que outra vez se reergueu aos olhos do autor incansável. A cada surgimento do limite, o texto se realimenta. A parede existe para ser destruída parece dizer o texto, não existe para ser vista ou justificada, mas apenas para ser destruída - para, novamente parede, ser de novo ruínas. (CARNEIRO, 2013, p. 89).

Podemos definir a arte literária desse autor mineiro como uma escrita que se reinventa por todos os caminhos possíveis do insólito. Em carta a Murilo Rubião o escritor memorialista Pedro Nava (2018) escreve: “[...] agradeço a remessa de O pirotécnico Zacarias. Conto ou poesia? Poesia - porque só ela permite tanta supressão (e retomada) do Tempo e do Espaço e o uso que você faz do absurdo nosso de cada dia...”. Nava põe em relevo um aspecto singular dos contos murilianos: a conjunção fortuita entre narrativa e poesia, que, em nossa leitura, nasce de um jogo entre o dito e o não dito, entre o revelado e o encoberto, entre silêncios e palavras. Rosalba Campra, ao tratar dos territórios da literatura fantástica, dedica um capítulo aos desafios do silêncio e afirma: "Dormências oportunas. Escuridões. [...] Tematizações e 
interrupções do discurso são formas do silêncio com que o texto constrói seu sentido fantástico" (CAMPRA, 2016, p. 123). Por isso ela defende que a literatura fantástica é uma poética dos vazios, visto irromper por meio muito mais dos espaços lacunares do que dos espaços dos ditos.

O dossiê aqui apresentado reúne textos que, a partir de variadas perspectivas, deslindarão a poética desse contista de valor ímpar no cenário da literatura fantástica mundial. $\mathrm{O}$ artigo Murilo Rubião: teórico e crítico de sua própria escrita propõe pensar o fantástico a partir das reflexões realizadas pelo próprio Murilo Rubião, apontando que o fantástico não se alterou ao longo do século XX, mas o que há é a irrupção de uma nova forma de conceber a literatura fantástica marcada pelas mudanças socioculturais de nossa contemporaneidade. $O$ processo criativo de Murilo Rubião: a busca do sentido perdido traz a lume o procedimento literário inscrito na obra de Murilo Rubião, apontando elementos subjacentes ao texto literário e mostrando que o dizer e a produção de sentidos ultrapassam o plano das palavras. A autora de "Petúnia", de Murilo Rubião e o diálogo com os contos populares impulsiona um diálogo profícuo entre o conto "Petúnia" e os mitos e contos de fadas tradicionais, demonstrando como algumas temáticas são recorrentes na tessitura contística de Murilo Rubião. No artigo Histórias de uma fila: A fila" (1974), de Murilo Rubião, e o Brasil dos anos de chumbo, os autores ponderam sobre o momento autoritário da ditatura no Brasil a partir da narrativa fantástica de Murilo Rubião, demonstrando como é possível pensarmos nossa realidade a partir do fantástico. Em Armação de mundo possível e processos de composição de personagens insólitos em "O pirotécnico Zacarias”, de Murilo Rubião, emerge a discussão acerca da composição dos mundos possíveis e insólitos na obra de Rubião, revelando como tal composição impulsiona a deflagração de uma multiplicidade de sentidos na leitura das narrativas. O artigo intitulado Sob os domínios do animal: um estudo do conto "Os dragões", de Murilo Rubião, discute as fronteiras entre imaginação e realidade a partir dos personagens animais no conto "Os dragões" do autor mineiro, marcando a potencialidade do caráter fantástico dos contos contemporâneos. Já em Os lados do círculo em "Os três nomes de Godofredo” de Murilo Rubião reflete-se sobre a narrativa de Rubião, colocando em relevo a figura geométrica do círculo e ressaltando como ela permite a inserção do leitor no texto literário. O artigo Os insólitos corpos de Murilo Rubião: uma leitura de "Bárbara" e "As unhas" permite questionar a ordem social e suas imposições, a partir da irrupção das transformações corporais insólitas que são configuradas nas narrativas do autor em foco neste dossiê. O texto Curta Murilo: Insólitas pirotecnias entre textos e tela demonstra a importância da obra de Murilo Rubião e a irrupção do insólito em suas narrativas a partir da análise de um de seus contos e da sua transposição em outras mídias, como a animação de Olímpio Costa. Por fim, o artigo Murilo Rubião e José J. Veiga e a oposição ao 
racionalismo nos contos "O lodo" e "Os Cascamorros": breves considerações reflete acerca do realismo mágico em contraposição ao racionalismo, apontando determinadas condutas e padrões ditados pelos mecanismos de poder na contemporaneidade.

A imagem de pirotécnico que escolhemos para figurar no título do dossiê que aqui se apresenta advém de um dos seus contos - "O pirotécnico Zacarias" -, e com ela pretendemos evocar a ideia de uma obra explosiva, que destronou alguns paradigmas estéticos em seu tempo e ainda vem iluminando novas perspectivas no campo da literatura fantástica. Nesse sentido, este dossiê seleciona e apresenta trabalhos que demonstram as muitas veredas insólitas e fantásticas que os contos murilianos encerram.

\author{
Marisa Martins Gama-Khalil (UFU/CNPq) \\ Maria João Simões (Universidade de Coimbra) \\ Adelaide Caramuru Cezar (UEL) \\ (Organizadoras)
}

\title{
Referências
}

ARRIGUCCI JR., Davi. Enigma e comentário: ensaios sobre literatura e experiência. São Paulo: Companhia das Letras, 1987.

ASSIS, Machado de. Memórias póstumas de Brás Cubas. Rio de Janeiro: Tecnoprint, 1985.

CAMPRA, Rosalba. Territórios da ficção fantástica. Rio de Janeiro: Dialogarts, 2016.

CANDIDO, Antonio. A nova narrativa. In: A educação pela noite. Ouro sobre Azul: Rio de Janeiro, 2006, p. 241-260.

CANDIDO, Antonio. Carta. Disponível em: <http://www.murilorubiao.com.br>. Acesso em: 22 nov. 2018.

CARNEIRO, Flávio. Escrever é escrever de novo: a escrita infinita em Murilo Rubião. In: GARCÍA, Flavio; BATALHA, Maria Cristina (Org.). Murilo Rubião: 20 anos depois da sua morte. Rio de Janeiro: EDUERJ, 2013.

COVIZZI, Lenira Marques. O insólito em Guimarães Rosa e Borges. São Paulo: Editora Ática, 1978.

GAMA-KHALIL, Marisa Martins. Murilo Rubião nos arredores do mito e do real maravilhoso. Literartes, n. 6, p. 46-70, dez. 2016.

GOULART, Audemaro Taranto. O conto fantástico de Murilo Rubião. Belo Horizonte: Lê, 1995. 
MORAES, Marco Antonio de (Org.). Mário e o pirotécnico aprendiz: cartas de Mário de Andrade e Murilo Rubião. Belo Horizonte: Ed. UFMG; São Paulo: Giordano, 1995.

NAVA, Pedro. Carta. Disponível em: <http://www.murilorubiao.com.br>. Acesso em: 22 nov. 2018.

ROAS, David. Tras los límites de lo real: Una definición de lo fantástico. Madrid: Páginas de Espuma, 2011.

RUBIÃO, Murilo. Autoretrato. Disponível em: $<$ http://www.murilorubiao.com.br>. Acesso em: 22 nov. 2018.

RUBIÃO. Murilo. Entrevista a J. A. de Granville Ponce. In : O pirotécnico Zacarias. São Paulo: Ática, 1986.

SILVEIRA, Nubia. Julio Cortázar, um homem amável que gostava de escrever cartas. Disponível em: $<$ http://www.sul21.com.br/jornal/2011/07>. Acesso em: 26 nov. 2012. 


\section{Artigos}

\section{Murilo Rubião: teórico e crítico de sua própria escrita Murilo Rubião: Theoryzing and criticizing his own writings}

Fábio Lucas Pierini*

\begin{abstract}
RESUMO: Quando lemos os contos de Murilo Rubião à luz de suas próprias reflexões sobre o fantástico, descobrimos que o autor tinha plena consciência teórica e crítica sobre sua escrita. Entretanto, comparando suas declarações de natureza crítica e teórica com a abordagem sociocognitiva do fantástico, percebemos que o autor brasileiro não pratica o fantástico, pois esse remete à defesa de um sistema de crenças em vias de extinção pela revolução industrial do século XIX. Também, dentro da mesma abordagem sociocognitiva, é possível afirmar que o fantástico não se transformou no decorrer do século XX: o que ocorreu, do nosso ponto de vista, é que um novo gênero narrativo se consolidou diante das novas condições socioculturais impostas pela guerra fria. Enquanto o fantástico buscava incutir no leitor a dúvida sobre a realidade de um acontecimento, esse novo gênero, o insólito, questiona o próprio conceito de realidade.
\end{abstract}

PALAVRAS-CHAVE: Fantástico. Insólito. Abordagem sociocognitiva.

\begin{abstract}
When we read Murilo Rubião's short stories in the light of his own reflections about the fantastic, we discover that the author had total critical and theoretical understanding of his own writings. However, by comparing his critical and theoretical statements with the social and cognitive approach to the fantastic, we perceive that the Brazilian writer does not deal with the fantastic, which is related to the defense of a belief system about to be extinguished by the $19^{\text {th }}$-century industrial revolution. Also from a social and cognitive approach, it is possible to say that the fantastic did not change over the 20th century: what happened, from our point of view, was that a new genre appeared in a context of new social and cultural conditions imposed by the cold war. While the fantastic intended to cast doubt on the reality of an event, this new genre, the insolitus, challenges the very concept of reality.
\end{abstract}

KEYWORDS: Fantastic. Insolitus. Socialcognitive approach.

Muitas são as abordagens da literatura fantástica desde o trabalho pioneiro de Charles Nodier (Du fantastique en littérature, 1830). Basicamente, discute-se se o fantástico é um gênero à parte, constituído no século XIX a partir da obra de E.T.A. Hoffmann, ou se é um recurso literário, uma figura de pensamento ou modo narrativo existente desde o princípio dos

\footnotetext{
* Com pós-doutorado em Estudos Literários pela Unesp FCL/CAr, é Doutor em Estudos Linguísticos, Literários e Tradutológicos em Francês pela Universidade de São Paulo (USP) e mestre em Estudos Literários pela Unesp FCL Araraquara, leciona Língua e Literatura Francesas na Universidade Estadual de Maringá (UEM) com ênfase em Teoria e Crítica da Literatura Fantástica no programa de Pós-graduação em Letras; Tradução e Interpretação no curso de Graduação em Secretariado Executivo Trilíngue; e Didática do Ensino de Língua Francesa no curso de Graduação em Letras. Desenvolve atualmente um projeto de pesquisa docente sobre a Sociocrítica da Literatura Fantástica a partir das narrativas finisseculares de Jean Lorrain e suas ligações com ETA Hoffmann et Franz Kafka. Orienta em nível de Iniciação Científica e de Mestrado em Literatura Fantástica, Insólito, Realismo Mágico e Conto Maravilhoso.
} 
tempos. A nosso ver, a figura de pensamento, materializada no sobrenatural, é algo totalmente distinto do gênero narrativo consolidado no decorrer do século XIX. Porém, enquanto o sobrenatural é independente do gênero em que se manifesta, o fantástico depende dele para existir enquanto tal.

Sabemos haver tanto receio quanto indiferença no uso do termo "sobrenatural" para falar de narrativas de ficção, mas, desde que se limitem as fronteiras de seu significado à sua aplicação na análise do texto literário, é possível empregá-lo de forma relativamente segura. Assim também foi por herança da crítica de língua francesa nos estudos literários brasileiros que surgiram as dificuldades de se entender o fantástico como sendo um gênero narrativo propriamente dito independentemente de o sobrenatural ocorrer de fato ou por engano de percepção.

O problema terminológico do fantástico em função da língua francesa ocorre por duas razões elementares. A primeira delas, comentada por Scheneider (1985), Ponnau (1997) e Mellier (1999) é que Loève-Veimars, tradutor de Hoffmann para o francês, traduziu o título da coletânea de contos do autor alemão Phantasiestücke in Callots Manier (1814) como Contes fantastiques, em 1829. Como o termo "fantástico" em francês tinha uma conotação muito vaga, sendo muitas vezes sinônimo de fantasia ou imaginação, ganhou a posição de termo literário para designar obras de ficção escritas à moda de Hoffmann. O mesmo ocorre na Rússia alguns anos antes, onde Hoffmann é traduzido e celebrado por vários autores, que também atribuem a suas obras a classificação de fantásticas. Segundo Fournier-Kiss (2007), o próprio Dostoievski denominava seu método de escrita de "realismo fantástico". Ainda no caso da Rússia, Tomachevski (apud Todorov, 2010) faz algumas considerações sobre o fantástico em seu livro Teoria da literatura (1925) dentro da mesma ótica.

A segunda razão pela qual encontramos um problema terminológico nos estudos do fantástico em função da língua francesa é justamente a obra mais difundida nesse campo, Introdução à literatura fantástica (TODOROV, 2010), originalmente publicada em 1969. No segundo capítulo do citado trabalho, Todorov alega o seguinte:

Num mundo que é exatamente o nosso, aquele que conhecemos, sem diabos, sílfides nem vampiros, produz-se um acontecimento que não pode ser explicado pelas leis deste mesmo mundo familiar. Aquele que o percebe deve optar por uma das duas soluções possíveis; ou se trata de uma ilusão dos sentidos, de um produto da imaginação e nesse caso as leis do mundo continuam a ser o que são; ou então o acontecimento realmente ocorreu, é parte integrante da realidade, mas nesse caso esta realidade é regida por leis desconhecidas para nós. Ou o diabo é uma ilusão, um ser imaginário; ou então existe realmente, exatamente como os outros seres vivos: com a ressalva de 
que raramente o encontramos [...] O fantástico ocorre nesta incerteza; ao escolher uma ou outra resposta, deixa-se o fantástico para se entrar num gênero vizinho, o estranho ou o maravilhoso. $O$ fantástico é a hesitação experimentada por um ser que só conhece as leis naturais, face a um acontecimento aparentemente sobrenatural. (TODOROV, 2010, p. 30-31)

Antes, porém, de acusarmos Todorov de ter transferido uma dúvida que era para ser de personagem e leitor para os críticos e estudiosos do fantástico, façamos justiça à sua intenção. Logo em seguida do trecho citado, afirma que "conceito de fantástico se define, pois, com relação aos de real e de imaginário" (idem, p. 31) e que tal relação será discutida no último capítulo do livro.

No referido capítulo, Todorov divide as funções do sobrenatural em literária e social. No caso da função social, o autor explica que o fantástico normalmente lida com assuntos proibidos e condenados pela sociedade e por isso "a introdução de elementos sobrenaturais é um recurso para evitar esta condenação [...] a função do sobrenatural é subtrair o texto à ação da lei e com isto mesmo transgredi-la" (ibidem, p. 168). Mas, com o advento da psicanálise, o fantástico se tornou inútil para esse fim, pois os temas proibidos tratados indiretamente pelo sobrenatural eram agora objeto de investigação científica: “O psicanalista tem aí uma atitude análoga à do narrador de um conto fantástico afirmando que existe uma relação causal entre fatos aparentemente independentes" (TODOROV, 2010, p. 170).

Com relação à função literária, Todorov distingue três funções:

A função pragmática: o sobrenatural emociona, assusta ou simplesmente mantém em suspense o leitor. Uma função semântica: o sobrenatural constitui sua própria manifestação, é uma autodesignação. Enfim, uma função sintática: ela entra, dissemos, no desenvolvimento da narrativa. (TODOROV, 2010, p. 171)

Tal função sintática do sobrenatural na narrativa fantástica seria um recurso narrativo por meio do qual o autor pode "desembargar" o andamento da narrativa. Se por qualquer razão o enredo encontra-se num ponto sem perspectiva de progresso por meios verossímeis, o autor lança mão de um elemento sobrenatural que lhe dê um novo rumo. Todorov conclui, portanto, que tanto na vida social quanto no interior de uma narrativa, o sobrenatural é uma transgressão da lei: "a intervenção do elemento sobrenatural constitui sempre uma ruptura no sistema de regras preestabelecidas e nela encontra justificação" (idem, p. 174). 
Dando continuidade a essa reflexão, Todorov aventa a tese de que o fantástico não existe mais a partir do século XX, argumentando que "a literatura fantástica deixa-nos entre as mãos duas noções, a da realidade e a da literatura, ambas insatisfatórias" (ibidem, p. 176) e que

[o] século XIX vivia, é verdade, numa metafísica do real e do imaginário, e a literatura fantástica nada mais é do que a má consciência deste século XIX positivista. Mas hoje, não se pode mais acreditar numa realidade imutável, externa, nem em uma literatura que não fosse senão a transcrição desta realidade. As palavras ganharam uma autonomia que as coisas perderam. A literatura que sempre afirmou esta outra visão é sem dúvida um dos móveis da evolução. A literatura fantástica, ela mesma, que subverteu ao longo de todas as suas páginas, as categorizações linguísticas, recebeu com isto um golpe fatal; mas desta morte, deste suicídio nasceu uma nova literatura. (TODOROV, 2010, p. 176-177)

Embora se trate de uma teoria elegante e de fácil assimilação - provável razão pela qual foi quase imediatamente traduzida para vários idiomas poucos anos após sua primeira edição e ainda recebe reedições -, Todorov restringiu o estudo do fantástico em dois níveis: no terminológico e no ideológico.

No caso da restrição terminológica, o trabalho de Todorov aprofundou as dificuldades já iniciadas pelo caso Phantasiestücke, pois várias novas nomenclaturas foram criadas para lidar com narrativas de ficção que poderiam comodamente ser consideradas fantásticas. Por se basear na definição de Tomachevski, tão limitada quanto à dos franceses do século XIX, o estudioso búlgaro atribui a uma manifestação ideal, visto que seu corpus é restrito e seu objetivo é descobrir um mecanismo interno da narrativa fantástica e não fazer um levantamento sistemático e exaustivo que comprove sua tese.

A restrição ideológica é a de que o sobrenatural é exclusivamente uma questão literária e resta a impressão de que todos os leitores são intelectuais preocupados com os aspectos formais do texto ficcional, sendo eles, por sua vez, totalmente desprovidos de crenças. Todorov simplesmente trancou a questão dentro dos domínios do texto e mesmo quando ele fala em "função social do sobrenatural" trata desta apenas como sendo um recurso narrativo que os autores usam para escapar da lei. Dessa forma, o fantástico seria apenas um exercício estético da parte do autor para uma apreciação estética do leitor.

Entretanto, sabemos que o leitor do fantástico em geral não é um intelectual versado em teorias literárias, especialmente se considerarmos sua popularidade e sua apreciação pelas mais variadas camadas socioculturais da população leitora. E para que o sobrenatural, no caso da 
narrativa fantástica, faça sentido para o leitor, é preciso que ele saiba o que é o sobrenatural de um ponto de vista verossímil e não como produto exclusivo da linguagem ${ }^{1}$.

Dessa forma, podemos nos apoiar em Lovecraft (2008), que alega o seguinte em Horror sobrenatural em literatura:

Embora a zona do desconhecido venha se contraindo regularmente há milhares de anos, um reservatório infinito de mistério ainda engolfa a maior parte do cosmo exterior, enquanto um vasto resíduo de associações poderosas herdadas se agarra a todos os objetos e processos que um dia foram misteriosos, por melhor que hoje possam ser explicados. E, mais que isso, existe uma fixação fisiológica real dos velhos instintos em nosso tecido nervoso que os tornaria misteriosamente operantes mesmo se a mente consciente fosse purgada de todas as fontes de assombro. (LOVECRAFT, 2008, p. 15)

Essa fixação fisiológica que tornaria nossos velhos instintos operantes provavelmente seria o sentimento do inquietante (Das Unheimlich), conceito ressignificado por Freud em seu artigo homônimo de 1919, em que o pai da psicanálise analisa o complexo de castração no conto $O$ homem da areia (1815) de E.T.A. Hoffmann. No entanto, o artigo, que demonstra claros interesses psicanalíticos, revela-se esclarecedor no que concerne à narrativa fantástica e a sua relação com o leitor. O sentimento de inquietação surge basicamente do conflito entre consciência e percepção, provocando uma sensação de familiaridade junto a um objeto ou situação estranha, bem como outra sensação de estranhamento diante de elementos e fatos familiares. Tal sentimento é desencadeado por duas situações: pelos estados alterados de consciência (o sonho, o uso de drogas, a loucura) ou pelas coincidências fortuitas.

Eis então como a mente humana pode considerar o sobrenatural algo plausível: sua capacidade inata de perceber a ação de forças desconhecidas sobre o próprio destino. Por questões evolucionárias, atribuímos correntemente a responsabilidade por eventos de causa desconhecida a seres sobrenaturais, já que a personalização é uma forma de tornar um evento compreensível, pois o coloca em termos humanos (LAKOFF E JOHNSON, 1980). É dessa maneira que a leitura de uma narrativa fantástica se torna uma experiência significativa: por atender a nossa necessidade inata de atribuir agência ${ }^{2}$ a fenômenos de causa desconhecida. Com

\footnotetext{
${ }^{1}$ Consideramos aqui verossimilhança não uma técnica narrativa, mas uma competência de leitura, uma capacidade humana de verificar mentalmente a plausibilidade de um evento narrado, seja ele ficcional ou não.

${ }^{2}$ Segundo Scott Atran (2002), agência é uma capacidade inata de detectar agentes no meio ambiente, normalmente predadores, presas e aliados. Entretanto, como subproduto dessa capacidade, surge a faculdade de reconhecer ou mesmo criar um agente como desencadeador de uma sequência de eventos de causa desconhecida. Esse princípio
} 
o tempo, a cultura, representada pelo conto popular, os contos de fadas e o folclore, assim como mitos, lendas e mesmo a religião, deu forma e nome a esses fenômenos, dando origem aos seres sobrenaturais que hoje conhecemos.

O fantástico, portanto, é uma narrativa de ficção situada na realidade referencial em que ocorre um fenômeno sobrenatural que remete à necessidade sociocognitiva de atribuir agência a fenômenos de causa desconhecida do mundo real. Trata-se, nessa perspectiva, da defesa de um sistema de crenças contra as forças massificadoras da revolução industrial, cujo êxito dependia (e ainda depende) de consumo e produtividade, ou seja, instâncias incompatíveis com esse modo de vida arcaico e tradicional. Sendo assim, essa narrativa sempre fará sentido enquanto a necessidade sociocognitiva existir e, considerando a produção literária contemporânea, a despeito das afirmações de Todorov, o fantástico ainda persiste, mesmo sem a sofisticação e a complexidade dos autores do século XIX.

Depois desse percurso ${ }^{3}$, cabe a seguinte questão: é isso o que Murilo Rubião faz em suas narrativas? Defende um sistema de crenças calcado no imaginário popular? Vejamos o que o próprio autor diz em entrevista a Elizabeth Lowe, publicada na revista Chasqui em 1978, quando perguntado sobre uma definição literária do fantástico:

Acho que a definição estruturalista de Todorov do fantástico é muito precária. O fantástico em nosso século, cujo maior precursor é Kafka, e aqui no Brasil é Machado de Assis, é muito diferente daquele do século XIX. No século passado, o fantástico era mais trágico e sombrio, como vemos nos contos de Edgar Allan Poe ou de Hoffmann. Hoje nós não temos a mesma relutância em aceitar o fantástico que teve o leitor do século passado. Este aquele sempre pensava que havia no fundo um certo realismo, que o fantástico não era uma irrealidade completa. No fantástico moderno há uma necessidade do escritor impor a sua irrealidade como se fosse real a ponto de o leitor, terminando a leitura, ficar numa certa dúvida se a realidade em que vive não será falsa, e se a realidade verdadeira não será aquela da ficção. Os tempos, as histórias, obrigam o escritor a tomar uma posição diferente daquela dos séculos anteriores. Não caberiam mais os contos de fadas, o fantástico sombrio, porque o leitor moderno não os aceitaria, se bem que os contos de fadas ainda sejam obras do melhor realismo fantástico, no sentido moderno ou antigo da expressão. (RUBIÃO, 1978, p. 27)

permite compreender desde a eficiência de figuras de linguagem como a personificação até a criação de seres sobrenaturais. Para maiores informações, ver páginas 59-79.

3 Para uma discussão mais detalhada e aprofundada sobre essa questão, referir-se ao artigo Uma abordagem sociocognitiva da narrativa fantástica, de nossa autoria, recentemente aceito para publicação na revista Abusões, da UERJ, ainda a ser publicado no segundo semestre de 2017. 
Diferentemente do que sentencia Todorov, para Rubião, o fantástico não morreu, apenas se transformou. Entretanto, é preciso compreender que Rubião não se preocupa com nomenclaturas dos estudos literários, considerando "fantástico" abertamente como uma categoria geral de textos em que o sobrenatural ocorre. Em entrevista a Alexandre Marinho e Francisco de Morais Mendes, publicada no Correio Braziliense de 27 de agosto de 1989, o autor alega aceitar com tranquilidade a classificação de sua obra tanto como "realismo mágico" quanto como "realismo fantástico".

Contudo, cabe notar que Rubião considera o efeito do texto literário sobre o leitor. Ao alegar que o fantástico do século XX é diferente daquele do XIX em função da aceitação do leitor, o escritor mineiro mostra consciência tanto como autor quanto como leitor. Essa consciência surge de vários aspectos, mas para os objetivos deste trabalho podemos limitá-los à sua visão agnóstica do mundo e à sua formação intelectual como leitor de literatura fantástica. Em sua última entrevista à Folha de S. Paulo, em 05 de outubro de 1991, poucos dias antes de morrer, Rubião declara ser cético e agnóstico, mas com um sentimento religioso profundo, mesmo alegando não acreditar em vida após a morte, porque, se a eternidade existisse, isso seria um castigo. Essa religiosidade, resultado de sua formação judaico-cristã, é aparentemente uma forma de gratidão e reconhecimento pela formação que a leitura da Bíblia lhe deu e que se reflete na escolha das epígrafes que invariavelmente abrem seus contos.

O uso de epígrafes, analisado detalhadamente por Schwartz (1981), é uma forma de ligar o texto de Rubião a uma tradição literária sobrenatural de cunho profético e violento, composta de obras escritas por homens que, segundo o próprio Rubião em entrevista à revista Chasqui, temiam a um deus violento, pouco compreensivo, mas autêntico. Como intelectual que conviveu com o poder - Rubião foi secretário de Juscelino Kubitschek quando este foi governador do Estado de Minas Gerais, chefe do escritório de propaganda e expansão comercial do Brasil em Madrid, na Espanha nos anos 1950 - ele conheceu os meandros da política local e internacional e o terror da guerra fria, trazendo para seus textos a tendência apocalíptica da ficção urbana:

Debaixo dessa sombra da bomba atômica, estamos sempre sob o terror de que a cidade possa ser destruída. Os profetas pediram ou profetizaram a destruição de Sodoma e Gomorra e de outras cidades, evidentemente pensando em construir um mundo novo, uma vida nova, cidades novas. Mas a minha geração e a geração de hoje, não tem esperanças de que da destruição da cidade surjam outras. A destruição será total. (RUBIÃO, 1978, p. 29) 
Essa falta de esperança e a descrença num além sobrenatural levaram o autor a viver num círculo entre a recusa da morte em vida e a da eternidade. Consequentemente, conforme entrevista a Walter Sebastião, na Tribuna de Minas de 03 de junho de 1988, Rubião diz não acreditar também na existência da fantasia, pois a ficção, por mais irreal que seja, está imbuída das contradições do real:

Acho que a fantasia não existe. Às vezes a vida dá a impressão de ser absolutamente irreal e, mesmo, que a normalidade está é nesses textos da chamada literatura fantástica. A literatura fantástica é muito mais normal do que a vida. Esta irrealidade da vida é um dado muito concreto. De vez em quando, a gente fica espantado com as coisas do cotidiano. Acontecem coisas estranhíssimas. Basta abrir um jornal e conferir. (RUBIÃO, 1988, s/p)

Mesmo evitando impor um sentido moral às suas narrativas, dando liberdade à interpretação do leitor, Rubião alega que a história em si acaba por ter uma moral dentro de um fato social. Dessa forma, é possível entender que sua obra envereda pelo que ele entende ser o fantástico não apenas por sua visão de mundo, que enxerga o irreal no real cotidiano, mas também por sua formação como leitor:

O mágico do meu trabalho é resultado de uma série de coisas, fatos da vida, de minha vivência e, principalmente, influência de leituras. Na minha infância eu fui muito ligado às histórias de fadas. As leituras que mais entusiasmaram foram aquelas ligadas ao fantástico europeu [...] Como ninguém consegue fazer uma coisa absolutamente original, nos meus textos trago influências dessas leituras, amadurecidas e trabalhadas, que vão dar origem a esse tipo de texto [...] Um autor que teve uma influência enorme sobre o meu trabalho foi o [Adelbert] von Chamisso, um naturalista alemão, que escreveu histórias para crianças com influência das narrações do folclore alemão. Ele tem um texto chamado "O homem que perdeu a sombra" [A maravilhosa história de Peter Schlemihl, 1814] que é estranhíssimo. Ele realizava, ainda no final do século passado, esta literatura do tipo do Kafka. (RUBIÃO, 1988, s/p)

Neste ponto é preciso fazer algumas considerações sobre a opinião crítica de Rubião, especialmente no que diz respeito às afinidades entre sua obra e a kafkiana. Chamisso é contemporâneo de Hoffmann e A maravilhosa história de Peter Schlemihl é publicado um ano antes de $O$ homem da areia (1815), conto pelo qual Hoffmann é mais lembrado. Trata-se dos primórdios da narrativa fantástica como a conhecemos e é fundamental lembrarmo-nos da presença do diabo no conto de Chamisso: Peter Schlemihl não perde sua sombra, ele a vende ao diabo em troca de uma bolsa de moedas cujo conteúdo jamais acabe. Existem mais ou menos cem anos de diferença entre Chamisso e Kafka e, embora a intuição de Rubião acerca das linhas 
gerais do fantástico e do papel do sobrenatural na narrativa de ficção coincida com nossas pesquisas, o desconhecimento de uma história organizada do fantástico o levou a enxergar uma afinidade kafkiana onde ela não poderia existir. A simples presença do diabo na narrativa, principalmente com relação ao pacto diabólico, remete à existência de um além sobrenatural, coisa que a ficção kafkiana não admite, pois, para Kafka, assim como para Rubião, não há transcendência deste mundo para outro.

Rubião tem afinidades com Kafka - especialmente por causa da ausência de transcendência, mas também por causa do sobrenatural enquanto materialização da contradição entre uma realidade discursiva e outra referencial -, mas não teria sido por ele influenciado, pois, segundo alega, na mesma entrevista à Tribuna de Minas, só soube da existência de Kafka após mandar alguns contos para Mário de Andrade e este tê-lo alertado sobre as semelhanças. Rubião comenta que tais afinidades teriam surgido certamente de leituras em comum e que ambos poderiam ter lido o Velho Testamento, o fantástico alemão e o francês e Poe.

Em suas entrevistas existe também a referência ao Don Quixote de la Mancha. Sempre lidando com a questão do fantástico e da dissociação entre discurso e vivência, Rubião alega que esse conflito está presente não apenas no enredo da narrativa, mas também na sensibilidade do autor:

Evidentemente, a presença do fantástico é capital na minha obra. Todo escritor, depois de certa época, vive plenamente a literatura que faz, a ponto de não saber se ele está sendo influenciado pelo que escreve ou se está fazendo um tipo de literatura de acordo com a sua tradição, com o meio ambiente, com a realidade em que ele vive. A minha maior convivência foi sempre, desde a infância, com o fantástico. Talvez tenha sido a leitura dos contos infantis, dos contos de fada, a leitura do D. Quixote, uma leitura em que eu acredito plenamente. Dom Quixote e Sancho Panza (sic) eram para mim figuras absolutamente reais, aliás o Dom Quixote era sempre para mim mais real que o Sancho Panza, se bem que ele também tenha alguma coisa de fantástico. Mais tarde li uma série de pensadores que levam a gente a pensar em outra realidade, que não é essa que nós vivemos. Isso também foi um convite para o fantástico. (RUBIÃO, 1978, p. 26)

Ainda que Rubião apresente um texto enxuto e um estilo direto do narrador permitem, paradoxalmente, múltiplas possibilidades de interpretação. O desafio seria, portanto, encontrar a expressão que melhor comunicasse essa dificuldade de separar o real do irreal ou de entender como eles se relacionam:

O desafio principal é exatamente a dificuldade que o escritor tem de impor uma possível realidade como sendo realidade, o suprarreal dado em termos 
claros e normais. Como se a convivência cordial com os seus dragões, seus monstros, tivesse a maior naturalidade. Então o escritor tem primeiro é que conviver com o mistério. Depois de certa convivência ele passa a tratar o suprarreal como se fosse a realidade. Se ele cai na fantasia, no fantástico gratuito, ele não consegue impor o seu mistério. (RUBIÃO, 1978, p. 27)

Novamente o termo "fantasia" é empregado pelo autor com conotação negativa, ou seja, como sinônimo de "fantástico gratuito" ou, como já tratamos anteriormente, como um elemento desprovido de qualquer ligação com o real, sem a possibilidade de encontrar um referente correspondente. Além disso, Rubião usa o termo "suprarreal" para se referir não a uma realidade superior, mas a uma realidade oculta, o que é perceptível no uso da palavra "mistério", como algo com o que o autor precisa saber conviver e depois impor ao seu texto.

Essa realidade misteriosa que ocorre além do real não estaria nas coisas em si, conforme Rodrigues (1986) postula ao tratar da verossimilhança no fantástico:

Produzir uma arte verossímil, ou seja, operar a mimese, segundo os ideais aristotélicos, consistia em agir sobre a physis, criando, a partir de um trabalho artístico (techne), uma nova realidade feita de palavras (a literatura) [...] Nas modernas interpretações do texto aristotélico fica claro que a physis a que ele se refere não é uma natureza feita, o dado, o real empírico, que a arte "imitaria" e sim uma physis dinâmica, a capacidade da natureza de produzir seres completos. Physis como uma força estruturante. A característica mais marcante da arte, ou seja, da mimese artística, seria a sua capacidade de criar formas de existência com leis próprias (desde que tenham a necessária coerência e organicidade internas) através dos mecanismos de expressão, a saber: a metáfora, a metonímia, a alegoria, o símbolo, etc. (RODRIGUES, 1986, p. 20)

Nossa hipótese acerca do que Rubião chama de suprarreal é a de que ele está se referindo à physis, que não é um objeto ou um ser, mas uma força, um processo. Como já comentamos anteriormente no caso do fantástico nascido no século XIX, sua função era a de defender um sistema de crenças que originalmente personificou fenômenos de causa desconhecida. Com o passar do tempo, a cultura e a história incorporaram essas figuras de linguagem não como a personalização de processos, mas como entidades autônomas, desvinculadas do evento original que as produziu.

$\mathrm{O}$ que acontece em autores que utilizam elementos sobrenaturais em suas narrativas do século XX é que, embora eles tenham lido e se apropriado dos recursos narrativos de seus precursores, não o fazem pelas mesmas razões. O que os autores do século XIX e XX faziam e que muitos do XXI ainda fazem se parece com o fantástico hoffmanniano. Porém não é a mesma coisa que outros autores dos mesmos séculos XX e XXI, como Kafka e Rubião fizeram. Não é 
porque uma história se passa em nossa realidade referencial e nela se dá um fenômeno sobrenatural que estamos no domínio do fantástico. E não é porque os autores de escrita mais complexa e sofisticada não praticam o fantástico como em seu período clássico que ele morreu.

Dessa forma, podemos entender que, assim como criaturas sobrenaturais ou eventos também sobrenaturais como metamorfoses ou duplicações, entre outros elementos, são materializações de linguagem que permitem a delimitação de fenômenos de causa desconhecida ao nível da compreensão humana, o sobrenatural seria uma figura de pensamento transversal aos mais variados gêneros narrativos. Por essa razão, o estudo do texto literário precisa de uma abordagem mais ampla, que considere tanto os aspectos socioculturais, nos quais o autor esteve ou está imerso, bem como sua formação intelectual e tendências ideológicas, associados aos recursos de linguagem mobilizados para exercer efeito sobre a capacidade de compreensão do leitor.

Portanto, nenhum gênero narrativo desaparece nem obrigatoriamente se transforma para se adequar às condições contemporâneas às quais o autor é submetido. Qualquer gênero pode ser "ressuscitado" a qualquer momento, bastando que o escritor o domine suficientemente, ou abandonado, se não houver quem o pratique. O que ocorre é que a expressão por meios indiretos é uma eterna necessidade humana, pois só podemos entender o que não vivenciamos por meio da linguagem e, não havendo uma correspondência perfeita entre linguagem e realidade, nem mesmo uma total igualdade de vivências entre todas as pessoas vivas, é preciso recorrer a analogias. Algumas delas são mais fáceis de entender porque são recorrentes a um maior número de pessoas e por isso têm maior alcance. Outras se referem a experiências tão raras que são praticamente impossíveis de se compreender sem um cuidadoso trabalho de pesquisa.

No caso de Murilo Rubião, vemos contos em que o sobrenatural está presente, mas em outros não. E aí se coloca o problema: que fantástico é esse que pode prescindir do sobrenatural? Vejamos o que diz Jorge Schwartz:

Os elementos ficcionais reais e irreais compactuam dentro de sua realidade linguística e temática; consequentemente a finalidade não é mais despertar determinadas emoções, mas fazer coexistirem, através do artifício verbal, realidades de praxe incompatíveis, que fazem com que o leitor ultrapasse o nível ingênuo da leitura, levando-o a uma visão conotativa do texto [...] $\mathrm{O}$ elemento fantástico em Murilo Rubião dilui as relações tradicionais do texto com o receptor, instauradas pela narrativa de suspense, integrando o leitor dentro de um universo alicerçado num absurdo verossímil. (SCHWARTZ, 1981, p. 68-69) 
Com relação a elementos extraliterários que possibilitassem uma visão mais acessível da obra de Rubião, Schwartz (1981) levanta três aspectos: o religioso cristão, mais especificamente em relação ao sacrifício do inocente; o social, como uma crítica à burocracia e ao absurdo das leis; e o existencial, sobre o absurdo do estar-no-mundo. Considerando a entrevista à Elizabeth Lowe em que Murilo critica duramente a ditadura civil militar de 19641985, bem como um comentário de Rubião sobre a recepção do livro $O$ ex-mágico da taverna Minhota, publicado no jornal A manhã de 11 de dezembro de 1949, podemos fazer uso dessas informações para tornar nossas intenções mais transparentes:

Os meus heróis são apenas homens tristes, que não conseguiram entender as traições da amizade, não acharam sentido na fortuna ou não tiveram, ao menos, a companhia de um cão. Neles vive a solidão, a busca incessante da infância irrecuperável, o culto incompreendido do amor e uma silenciosa humildade frente ao mistério, que eles aceitam sem indagações, como se curvam diante dos irrecorríveis castigos a que estão sujeitos os escolhidos para serem mansos. A atmosfera irreal ou sobrenatural, que muitos julgam cercar as suas ações, existe somente para os que vivem à margem da vida, amealhando cruzeiros [moeda brasileira corrente na época] especulando com a falta de transportes, com a alta dos imóveis ou com as aberrações da inflação. Jamais sentiram o lirismo de colher seixos brancos, sem a mortal preocupação do colecionador. Homens sem esperança, incapazes de compreender, como o meu Pirotécnico, que, ás vezes, é preciso morrer para se ter uma vida autêntica. (A MANHÃ, 1949, s/p, apud SCHWARTZ, 1981, p. 96)

Basicamente, Rubião acusa seus "difamadores" de não entenderem suas narrativas por não terem tido uma vivência que as tornasse uma experiência significativa. Mesmo que as análises de Schwartz privilegiem o aspecto formal do texto de Rubião em detrimento de seu sentido, sua conclusão teórica é muito próxima da nossa tese e bastante distante das características que elencamos sobre o fantástico propriamente dito:

O simbolismo da linguagem fantástica em Murilo Rubião desvenda-se ao leitor como um sistema poroso que filtra constantemente os elementos sociais do texto. São raros os momentos na obra do autor em que o elemento insólito, ou mesmo o sobrenatural, não se converte em trampolim metafórico de uma crítica social [...] A possibilidade de conotação social enriquece o signo narrativo, permitindo que ele se projete além do fenômeno meramente ficcional. O elemento social é veiculado pela imagética fantástica, mimese inverossímil do universo. (SCHWARTZ, 1981, p. 77)

A obra de Rubião desconcerta por possuir uma coesão e coerência internas sem ser totalmente tributária das obras que ele próprio leu, como por exemplo, Quixote, contos de fadas, Hoffmann, Chamisso e Machado de Assis. O que podemos entender de sua obra em função das 
leituras feitas por Rubião é que o escritor percebeu no sobrenatural um meio de expressão para lidar com o real e torná-lo assimilável para seu público. Na já referida entrevista a Elizabeth Lowe, ele mesmo alega que o autor não pode descambar para o panfletário, mesmo que a militância seja inevitável.

Isso significa que os contos de Rubião, embora não sejam fantásticos na acepção clássica do termo, compartilham algumas características com o fantástico e exigem uma leitura alegórica para sua decifração. Bem sabemos a reticência com que pesquisadores do fantástico lidam com a alegoria, mas considerando a leitura que Viegnes (2006) faz do postulado de Todorov (2010) a respeito do assunto, aquele afirma que

Se concebermos a alegoria como uma sobreposição de níveis de sentido, nada impede então o funcionamento da narrativa alegórica enquanto narrativa fantástica [...] uma alegorização apoiada demais da narrativa que tendesse a um alegorismo destruiria qualquer efeito fantástico, mas um simbolismo sutil cria uma espécie de halo sugestivo ao redor dos fatos sem alterar seu poder de sideração [...] É quase evidente demais que vários motivos fantásticos podem ser lidos em dois níveis; de resto, a crítica de inspiração freudiana nos acostumou a buscar nas narrativas, assim como nos sonhos, o "conteúdo latente" por trás do "conteúdo manifesto". Sem entrar nos meandros da psicanálise, é fácil, por exemplo, desvendar as conotações eróticas do vampirismo sem que o sentido imediato do ato vampiro seja contestado. (VIEGNES, 2006, p. 20-21. Tradução nossa ${ }^{4}$ )

No entanto, a narrativa de Rubião não apresenta um simbolismo sutil. São narrativas que implicam um sentido segundo para serem compreendidas, pois estão bastante distantes das técnicas narrativas usadas pelos autores do fantástico. Ambas as características por nós apontadas, um sobrenatural desvinculado de um sistema de crenças e a necessidade de uma leitura alegórica, comprovam que Rubião não praticou o fantástico, mas o insólito, um gênero narrativo que se consolidou no contexto da guerra fria como sintoma de um mal estar diante do bombardeio de informações veiculadas de forma tendenciosa. Além da guerra fria, não nos esqueçamos de que Rubião escreveu durante o Estado Novo de Getúlio Vargas (1939-1945) e a ditadura civil-militar (1964-1985), governos que fizeram uso da censura aos meios de comunicação e intelectuais em geral, além da propaganda política e ideológica maciça.

\footnotetext{
4 Mais si l'on conçoit l'allégorie comme une superposition de niveaux de sens, rien n'empêche alors le fonctionnement du récit allégorique en tant que récit fantastique [...] une allégorisation trop appuyée du récit, qui tendrait à l'allégorisme, détruirait tout effet fantastique, mais un symbolisme subtil crée comme un halo suggestif autour des faits, sans altérer leur pouvoir de sidération [...] Il est presque trop évident que nombre de motifs fantastiques peuvent se lire à deux niveaux; du reste, la critique d'inspiration freudienne nous a habitués à chercher dans les récits, comme dans les rêves, le "contenu latent" derrière le "contenu manifeste". Sans entrer dans les méandres de la psychanalyse, il est facile, par exemple, de déceler les connotations érotiques du vampirisme.
} 
O insólito, assim como o fantástico foi no passado, é hoje considerado uma categoria de narrativas que exploram elementos não miméticos. Talvez nossa maior dificuldade não seja detectar novos gêneros narrativos, mas encontrar uma nomenclatura que seja genérica e comum a todos eles. Pierini (2017), faz um percurso teórico que traz à tona o histórico do uso do termo insólito para uma categoria de narrativas de ficção que, mesmo aparentando-se ao fantástico e até ao maravilhoso ou ao feérico, eram de difícil classificação para os editores das revistas literárias americanas e francesas dos anos 1950.

Nos anos 1950 e 1960, três autores refletiram sobre o insólito enquanto gênero narrativo específico, apartado tanto do fantástico quanto das demais narrativas não miméticas. O primeiro de todos foi Michel Guiomar, cujo artigo L'insolite foi originalmente publicado em 1957 na Revue d'Esthétique e depois republicado como capítulo do livro Principes d'une esthétique de la mort em 1968. O segundo foi Jacques Goimard, conforme relato em capítulo de Critique du fantastique et de l'insolite (2003) específico sobre o insólito, trata do uso do termo para fins de catalogar narrativas fora da classificação prévia da revista Fiction (versão francesa da revista homóloga estadunidense) e também como rótulo comercial, pois o termo "fantástico" na época era considerado relativo a histórias para velhos e crianças, o que afastava o público jovem, maior leitor e comprador da revista. Por fim, a terceira reflexão acerca do termo vem do livro Histoire de l'insolite (1964), do artista plástico Robert Miquel, sob o pseudônimo Romi. Para ele, o insólito é a manifestação do desejo humano de explorar o desconhecido.

Segundo Guiomar (1957 apud KOMANDERA, 2010), diferentemente do fantástico, o insólito é uma impressão coletiva, seja de um pequeno grupo, cidade ou país, pois se manifesta através de uma concepção de código cultural. Por surgir de uma desregulação das leis admitidas, existe apenas enquanto leitura não racional dos fatos, resultando na falta de hesitação e de angústia. O que ocorre é a manutenção da estrutura de uma realidade que não existe mais, por mudança na sua significação, provocando uma metamorfose da interpretação que fazemos dos fatos. Nesse caso, os seres e coisas ascendem a um novo estado: o inanimado se anima, o animal torna-se humano e o humano transcende para uma realidade cósmica e tudo ganha o poder de transmitir uma mensagem. Guiomar conclui que uma característica fundamental do insólito é o texto indecidível. Não se trata de hesitação, pois esta pressupõe opções sobre as quais decidir. Trata-se exatamente do que Rubião (1978) chama de deixar a obra "em aberto".

Considerando tais reflexões de Guiomar, podemos entender que a diferença elementar entre o fantástico e o insólito é que o primeiro questiona a realidade de um fato, já o segundo questiona o próprio conceito de realidade. O princípio fundamental para o questionamento do conceito de realidade reside na dissociação entre vivência e discurso. Ou seja, conforme já 
discutimos no caso do fantástico e do conflito entre percepção e consciência, criamos uma realidade paralela por meio da linguagem e acreditamos nela justamente pela nossa incapacidade de testemunhar e vivenciar todos os eventos da experiência humana. Esse “acreditar" depende de nossa competência natural para detectar o verossímil, que é limitada por sua vez à nossa vivência. Porém, na medida em que o fantástico usa a linguagem para tornar visível uma realidade invisível, o insólito exacerba a realidade visível de maneira a evidenciar a falta de sentido que acomete as relações humanas. E não há manifestação de linguagem que mais apresente dissociação entre discurso e vivência do que a lei.

Goimard (2003), divisa alguns elementos que se encadeiam nas narrativas do insólito no que diz respeito à lei, concluindo, em consonância com Sartre (2005), que se violam as leis quando se busca cumpri-las e estas são cumpridas quando se tenta violá-las. Num mundo em que a linguagem é mais forte do que o testemunho direto dos fatos e do que a vivência pessoal, fazendo dos meios fins em si mesmos, autores como Rubião buscaram subverter as regras da própria linguagem de maneira a denunciar essa contradição.

Em primeiro lugar, ainda conforme Goimard, os autores buscam a inovação e a originalidade a todo custo, mesmo que para isso distorçam completamente nosso senso do verossímil. Narrando de maneira fria, como o próprio Rubião alega fazer, esses autores desencadeiam uma sensação de falta de sentido: certamente porque sua técnica narrativa parodia a relação de sentido entre discurso e vivência, dando a impressão de estarmos lidando com uma mensagem sem conteúdo, nem meio, tampouco emissor. Em seguida, para cumprir esse objetivo, os autores lançam mão de recursos alegóricos, mas não da forma tradicional, que é associando um sentido segundo a uma figura primeira, mas fazendo com que o sentido segundo se torne real, concreto, se manifeste objetivamente no texto. Assim, deixa claro para o leitor que, embora aquela situação narrada só seja possível por meio da linguagem, pode-se vivenciar algo semelhante não como fato, mas como interpretação do fato. O leitor percebe haver ali uma denúncia, um alerta, mas não uma lição de moral.

Ao parodiar a relação de sentido entre a vivência e o discurso que a regula, o autor chega ao limite da criação textual, uma narrativa que depende, para ser compreendida, de uma vivência compartilhada e do conhecimento funcional das narrativas de ficção. Ou seja, mais uma vez, diferentemente do fantástico, que pode ser compreendido intuitivamente porque trata das reações primordiais da mente humana, o insólito depende de uma educação formal que inicie o leitor aos seus códigos. A principal delas é entender que a narrativa ficcional do insólito não é composta por um texto único que lida com duas realidades, mas dois textos disputando a hegemonia por uma única realidade. 
Vergopoulos (2010), ao discutir o insólito como gênero narrativo jornalístico típico da cultura francesa, fornece-nos dois conceitos fundamentais para entendermos o insólito como gênero narrativo, explicando todo o encadeamento de técnicas narrativas que foi exposto até aqui. Trata-se dos conceitos de "hipertexto" e "hipotexto" como duas faces de um mesmo texto. Entretanto, o hipotexto só pode ser suposto a partir do hipertexto. O hipertexto, que é a voz dominante, reporta a falta de lógica e de bom senso da voz dominada, o hipotexto. Para se sobrepor ao hipotexto, o hipertexto se apresenta como representante da ordem, acusando o hipotexto de ser um desvio da norma ou portador da desordem. Essa estrutura tem por objetivo manter o mistério, desenvolvendo uma tensão entre o dizer e o reter, o que produz conotações que se chocam com o senso comum. Dessa forma, a significação do insólito só pode ser encontrada nos não ditos do texto, nos choques estéticos produzidos, nos vazios e silêncios que excitam a imaginação do leitor em busca de uma imagem que materialize o não narrado.

O hermetismo ao qual o texto pode chegar torna-se a força autoral da subjetivação, resultando na imposição do ponto de vista do autor, um gesto sobre o mundo que redunda na apropriação do próprio mundo e da existência nele. E isso só é possível por meio da apresentação simultânea de duas lógicas que se regulam mutuamente: o "anódino" e o "extraordinário".

O anódino está presente na própria construção do tempo e do espaço na narrativa do insólito. A história se passa num tempo e num espaço que são aparentemente contemporâneos a autor e leitor, mas privados de referências mais precisas. É um mundo que se parece com o nosso, mas seus elementos concretos e seus referentes reais são extremamente depurados a ponto de se descaracterizarem culturalmente, dificultando uma leitura simbólica ou alegórica tradicional, evidentemente porque os elementos conotativos tornaram-se denotativos e qualquer vínculo com uma realidade extralinguística é muito difícil de estabelecer. Já o extraordinário (seja ele sobrenatural ou não) é um fenômeno coerente com a falta de lógica da narrativa, pois é previsível, mas inaceitável: o extraordinário nas narrativas do insólito simboliza a revelação de uma verdade que deveria ter sido mantida em segredo, pois sustenta não só o equilíbrio da realidade social como também a sanidade dos personagens.

O insólito nasce, portanto, da conscientização do poder da linguagem sobre a consciência do indivíduo. Revela-se no mundo da linguagem para revelá-lo como tal e torná-lo inteligível, configurando-se como um dispositivo do saber. 


\section{Conclusão}

Embora tenhamos desde sempre classificado as obras de Murilo Rubião como pertencentes a uma "vertente" do fantástico, essa nomenclatura não é possível à luz de uma abordagem que considere as próprias reflexões feitas pelo próprio autor acerca de seu processo de criação. Enquanto o fantástico se consolida no século XIX como forma de defender um sistema de crenças que sustentava um modo de vida originado no neolítico contra a força esmagadora da revolução industrial, Murilo Rubião produz, em pleno século XX, uma narrativa de ficção que denuncia as contradições entre discurso e vivência, ou seja, o insólito. Esse gênero narrativo não questiona a realidade de um evento, mas questiona o próprio conceito de realidade, o que é extremamente diferente.

O insólito nasce da percepção de haver um discurso acerca da realidade que não coincide com a impressão que o indivíduo tem dele. Considerando a sensibilidade artística que procura evitar o panfletarismo direto sem renunciar ao engajamento, os autores do século XX, que tiveram sua formação de leitores dentro de uma poética fantástica, reaproveitam o que o fantástico tinha de mais característico, o sobrenatural, fazendo dele não a personificação de um evento de causa desconhecida, mas a materialização do sentido segundo de uma alegoria ou metáfora estendida. Então, mais do que uma denúncia velada a um sistema político e ideológico indutor de determinados comportamentos à sociedade, esses escritores fazem uso de técnicas narrativas que emulam as contradições entre a realidade percebida pela população e o discurso oficial disseminador de uma interpretação enviesada dos fatos.

Essas narrativas constituem um desafio hermenêutico, pois exigem do leitor o conhecimento de mundo e uma noção de gêneros textuais que permitam entender quando um texto ficcional depende da decodificação de seus não ditos para ser compreendido. Num mundo em que os meios tornaram-se fins em si, não dependendo de uma finalidade que justifique sua existência, narrativas com enredo simples apenas divertem, ao invés de propor uma visão de mundo que, muitas vezes diferente daquela do leitor, o leve a questionar sobre sua condição e, por sua vez, impor sua vontade ao mundo, ao invés de render-se à produtividade e ao consumo.

O leitor do insólito não precisa necessariamente achar as correspondências simbólicas entre o que está no texto com aquilo que está no mundo em que ele vive porque o próprio texto é a materialização no mundo real da contradição entre vivência e discurso. Entender que o que importa não é o enredo propriamente dito, mas sim o fato de uma pessoa ter usado seu tempo e recursos para publicar esse texto é o que justifica o insólito. Quando o leitor for capaz de entender que o enredo do insólito não diz respeito a fatos, mas ao que pensamos deles como se 
esse pensamento tivesse naturalmente nascido em nossas mentes quando na verdade foi furtivamente plantado lá, ele terá chegado ao âmago do insólito.

Não à toa Rubião eivou seus contos de referências a profecias. A profecia é um discurso que só pode ser compreendido depois do ocorrido, quando ele já não tiver mais o valor de alerta, e sim tornar-se a cicatriz de uma inação. É muito pertinente afirmar que na obra de Rubião o que mais encontramos são personagens arrependidos ou em vias de se arrepender por não terem sabido interpretar os sinais de que algo de trágico ocorreria futuramente. Personagens que se deixam levar pelo fluxo narrativo sem nunca romper com a força de um código social que os impede de tomar o controle de suas vidas também são extremamente recorrentes.

O sobrenatural (quebra das leis físicas) e o absurdo (quebra das leis sociais, morais ou até mesmo psíquicas) nada mais são do que a consequência do pecado original: a desobediência. Porém, nos contos de Rubião, não se trata da desobediência à lei arbitrária de um deus autoritário; trata-se da recusa em buscar o conhecimento do bem e do mal e se responsabilizar pelos próprios atos. É a recusa da oportunidade de viver em liberdade.

\section{Referências}

ATRAN, S. In gods we trust. Nova Iorque: Oxford University Press, 2002.

BARONIAN, J.-B. Panorama de la littérature fantastique de langue française. Paris: Table Ronde, 2007.

BOYD, B. On the origin of stories. Cambridge/Londres: The Belknap of Harvard University Press, 2009.

BOZZETTO, R. L'obscur objet d'un désir. Fantastique et science-fiction: deux littératures de l'imaginaire. Aix-en-Provence: Presses Universitaires de Provence, 1992.

BOZZETTO, R.; HUfTIER, A. Les frontières du fantastique. Approches de l'impensable en littérature. Valenciennes: Presses Universitaires de Valenciennes, 2004.

FABRE, J. Le mirroir de sorcière. Essai sur la littérature fantastique. Paris: José Corti, 1992.

FOURNIER-KISS, C. La ville européenne dans la littérature fantastique au tournant du siècle (1860-1915). Paris: L'Âge d'homme, 2007.

FREUD, S. O inquietante. In: FREUD, S. Obras completas (1917-1920). São Paulo: Companhia das Letras, v. 14, 2010. p. 328-376.

GOIMARD, J. Critique du fantastique et de l'insolite. Paris: Pocket, 2003.

GUIOMAR, M. L'insolite. Revue d'Esthétique, Paris, v. 10, p. 113-144, 1957. 
KOMANDERA, A. Le conte insolite français au XXe siècle. Katowice: Wydawnictwo Universytetu Slaskiego, 2010.

LAKOFF, G.; JOHNSON, M. Metaphors we live by. Chicago/Londres: University of Chicago Press, 1980.

LOVECRAFT, H. P. Horror sobrenatural em literatura. São Paulo: Iluminuras, 2008.

MELLIER, D. L'écriture de l'excès. Fiction fantastique et poétique de la terreur. Paris: Honoré Champion, 1999.

MIQUEL, R. Histoire de l'insolite. Paris: Pont Royal, 1964.

PIERINI, F. L. Do insólito como um gênero narrativo. In: FERREIRA, C. C.; MIRANDA, C.V.M. Dimensões do insólito ficcional: Perspectivas teórico-analíticas sobre formas de narrar. Campinas: Pontes, 2017. p. 13-42.

PIERINI, F. L. Da lanterna mágica ao fantascópio: por uma sociocrítica do fantástico. In: SENA, A. D. Literatura fantástica em Pernambuco e outras histórias. Recife: Editora UFPE, 2015. p. 329-351.

PONNAU, G. La folie dans la littérature fantastique. Paris: Éditions du CNRS, 1997.

RODRIGUES, S. C. O fantástico. São Paulo: Ática, 1986.

RUBIÃO, M. Entrevista con Murilo Rubião. Revista Chasqui 07, no 03, Quito, 1978. 24-33.

RUBIÃO, M. As façanhas de um escritor mágico. Correio Braziliense, Brasília, 27 agosto 1988. s/p.

RUBIÃO, M. Sedutora profecia do contemporâneo. Tribuna de Minas, Belo Horizonte, 03 junho 1988. $\mathrm{s} / \mathrm{p}$.

RUBIÃO, M. A última entrevista. Folha de S. Paulo, São Paulo, 05 outubro 1991.

SARTRE, J.-P. Aminadab ou do fantástico considerado como uma linguagem. In: SARTRE, J.-P. Situations I. São Paulo: Cosac Naify, 2005. Cap. 2, p. 135-149.

SCHNEIDER, M. Histoire de la littérature fantastique en France. Paris: Fayard, 1985.

SCHWARTZ, J. Murilo Rubião: a poética do uroboro. São Paulo: Ática, 1981.

TODOROV, T. Introdução à literatura fantástica. São Paulo: Perspectiva, 2010.

VERGOPOULOS, H. Réponse à la question: qu'est-ce l'insolite? Communication et langages, p. 03$15,2010$.

VIEGNES, M. Le fantastique. Paris: Flammarion, 2006. 


\title{
O processo criativo de Murilo Rubião: a busca do sentido perdido The creative process in Murilo Rubião: In search for the lost sense
}

\author{
Audemaro Taranto Goulart*
}

\begin{abstract}
RESUMO: Este texto pretende focalizar o processo criativo do contista Murilo Rubião, partindo da singularidade que o autor demonstra de reescrever seus textos a cada nova publicação. A crítica tem visto essa disposição como um arranjo perfeccionista que faz parte da personalidade do escritor, mas a abordagem que se propõe intenta ir além dessa mera constatação. Reconhecendo que a linguagem não consegue dar conta da inteireza do real, a abordagem procura descobrir os elementos subsumidos no texto que apenas se insinuam e que caracterizam o mais-dizer de um texto que, na sua completude, está irremediavelmente perdido. Para tanto, trabalha categorias da narrativa como a fábula, o enredo e o discurso, procurando mostrar que para além do que está escrito proliferam sugestões que indicam a possibilidade de um dizer que decorre de uma projeção inconsciente e que torna mais aguda a intenção do escritor, ultrapassando a superfície gráfica do enredo. A análise procurará, então, descobrir o que aciona esse dizer, como é o caso da dimensão do trágico que subjaz oculta na narrativa que se escolhe para exemplificar a abordagem.
\end{abstract}

PALAVRAS-CHAVE: Murilo Rubião. Processo criativo. Discurso. Inconsciente. Trágico.

\begin{abstract}
This text focuses on the creative process of Brazilian writer Murilo Rubião by building on his singular rewriting of his own texts in each new publication. The criticism has seen this disposition as a perfectionist feature of the writer's personality, but the present approach intends to go beyond that. In recognizing that language cannot account for the the real in its entirety, it seeks to discover the elements subsumed in the text, which are only hinted at and characterize the further-saying of an irremediably lost text. To this end, it draws on such narrative categories as fable, plot and speech, seeking to show that beyond what is written are proliferating suggestions that indicate the possibility of a saying that stems from an unconscious projection and that enhances the writers' intention beyond the graphic surface of the plot. The analysis seeks to unveil what triggers that saying, as is the case of the tragic dimension that underlies and hides in the narrative choosen to illustrate the present approach.
\end{abstract}

KEYWORDS: Murilo Rubião. Creative process. Speech. Unconscious. Tragic.

\footnotetext{
* Possui graduação e licenciatura em Letras Anglo-germânicas pela Pontifícia Universidade Católica de Minas Gerais (1963-1964), Mestrado em Literatura Brasileira pela Universidade Federal de Minas Gerais (1985) e Doutorado em Teoria Literária e Literatura Comparada pela Universidade de São Paulo (1993). Atualmente, é professor titutlar nos cursos de graduação e de pós-graduação da Pontifícia Universidade Católica de Minas Gerais. Atua na área de Letras, com ênfase em Teoria da Literatura, Literatura Brasileira, Crítica Literária, Literatura e Filosofia e Literatura Comparada.
} 
Pode parecer estranho o título deste texto. Espero viabilizar seu entendimento ao longo do artigo mas, para que as coisas não fiquem pairando no ar, coloco uma afirmação de Octavio Paz, poeta e crítico mexicano, que pode trazer algum aclaramento: "O valor das palavras reside no sentido que ocultam. Ora, este sentido não é senão um esforço para alcançar algo que não pode ser alcançado realmente pelas palavras. Com efeito, o sentido aponta para as coisas, assinala-as, mas não as alcança jamais. Os objetos estão mais além da palavras” (1972, p. 43).

Feita a ressalva, inicio dizendo que a obra de Murilo Rubião está marcada por traços e aspectos singulares: a completa inserção no universo do fantástico, a presença de personagens emparedados a quem se nega qualquer concessão, o absurdo de situações que desafiam a lógica do cotidiano, a ausência de heroísmos na caracterização de personagens, presença de epígrafes em todos os contos, a incursão dos personagens no universo do trágico e uma compulsão de Murilo Rubião em republicar seus contos, reescrevendo-os a cada republicação.

É sobre este último aspecto que quero me deter: o notável número de republicações que Murilo Rubião fez ao longo de sua vida de escritor. Realmente, chama a atenção o fato de que 94 contos foram publicados, em vida do autor, mas desses, apenas trinta e três são rigorosamente originais, uma vez que, com o passar do tempo, Murilo fez nada menos que 61 republicações, quase o dobro da quantidade de textos originais.

Os números falam por si. O primeiro livro, O ex-mágico, publicado em 1947, trouxe 15 contos. O segundo, A estrela vermelha, de 1953, foi uma edição especial, com apenas 4 contos, numa tiragem de 110 exemplares destinados, praticamente, a ofertas da editora. Já no terceiro livro, Os dragões e outros contos, de 1965, começam as republicações, uma vez que dos 20 contos, oito já tinham saído no primeiro livro e quatro no segundo. Em 1974, sai o último livro inédito de Murilo Rubião, trazendo os nove contos de $O$ convidado. Daí para frente, só se têm republicações: O pirotécnico Zacarias, também de 1974, com seus oito contos, A casa do girassol vermelho, de 1978, com nove contos, Murilo Rubião - Literatura comentada, de 1982, com 19 contos, O homem do boné cinzento, de 1990, com nove contos, e um conto perdido, “A diáspora", que fora esquecido num táxi e que Murilo não conseguiu recuperar, o que o obrigou, bem de acordo com o mundo fantástico de seus contos, à surreal situação de reescrever um texto que nem fora publicado.

A crítica da obra muriliana tem falado desse vezo do autor de escrever e reescrever os seus textos. Veja-se que, dos 33 contos, apenas dois jamais foram reescritos. Trata-se de "Petúnia" e "O lodo", ambos de $O$ convidado. Aí está, inclusive, um bom exercício de atividade comparatista com os demais textos, que procuraria refletir sobre essa negativa de Murilo Rubião em relação aos dois contos. 
As explicações da crítica e de estudiosos para essa insólita reescrita dos contos desenvolve, na maior parte das vezes, a tese de que tudo se deve a um anseio perfeccionista de Rubião, como se pode ver na passagem abaixo em que o escritor refere-se ao seu processo criativo, dizendo o que a literatura lhe oferecia de prazer e de sofrimento:

Sempre aceitei a literatura como uma maldição. Poucos momentos de real satisfação ela me deu. Somente quanto estou criando uma história sinto prazer. Depois é essa tremenda luta com a palavra, é revirar o texto, elaborar e reelaborar, ir para frente, voltar. Rasgar. (RUBIÃO, 1981, p. 5)

Configura-se na passagem o modo como Murilo lidava com seus textos. De um começo prazeroso, o trabalho evoluía para um angustiante debruçar-se sobre o que fora escrito, espécie de um Narciso que não se vê na limpidez das águas do lago mas no turvo e misterioso poço da linguagem, tal como dá a ver uma frenética busca de um mais-dizer impossível. Impossível exatamente porque o mecanismo de que o escritor dispõe - a linguagem - é insuficiente para apreender o real sobre que se lança. Ainda assim, o escritor está sempre na esperança de alcançar aquele mais-dizer e é isso que imanta sua vida e seu desejo e que torna angustiante o seu trabalho.

Clarice Lispector já se referiu a essa angústia quando afirmou que as palavras escritas, na verdade, ocultam outras, as verdadeiras, que se escondem à consciência e à visão do escritor mas que, de alguma forma, estão ali, ciciando sua presença na grafia de outras palavras, denunciando o sofrimento que é a busca pelas palavras que existem mas que não se podem capturar. A referência às palavras de Clarice Lispector aponta uma notável afinidade com a afirmação de Octavio Paz, feita no início do artigo.

Essa luta do escritor no encalço da palavra perfeita está no nível do desejo, motivo por que seria oportuno recorrer às formulações freudianas em que se observa que o desejo está marcado por uma indestrutibilidade que traz consigo a persistência de uma insatisfação que jamais desaparece. Além do mais, o desejo mostra-se também como algo que nunca será alcançado uma vez que ele se caracteriza pela perda do objeto materno, uma perda definitiva que se dá com o nascimento e que configura a chamada falta, lacuna que se abre no sujeito ao se separar do complemento materno.

É nota dominante na caracterização do desejo o movimento de uma busca que se faz através de constantes transformações do objeto, autênticas operações metafóricas com que se busca a realização do desejo, naquela infrutífera tentativa de suprimir a falta. 
Como se pode ver, o processo de reescrita de Murilo Rubião ajusta-se perfeitamente a essas formulações psicanalíticas, na tentativa que o escritor empreende no sentido de encontrar um texto que, entretanto, está para sempre perdido.

Aliás, a preocupação de Murilo é a mesma de qualquer escritor: fisgar o leitor de seu texto e, para isso, é preciso aperfeiçoar cada vez mais o que está escrito. Nesse compasso, ele ilustra bem as colocações de Roland Barthes sobre essa especialíssima relação entre autor e leitor: "O texto que o senhor escreve tem de me dar prova de que ele me deseja. Essa prova existe: é a escritura. A escritura é isto: a ciência das fruições da linguagem, seu kama-sutra (desta ciência, só há um tratado: a própria escritura)" (1977, p. 11).

Esse desafio é responsável pela febricitante busca de Rubião pelo texto perfeito num exercício de sofrimento que parece não ter limites. Essa, ansiedade, aliás, está bem perto de outras colocações de Barthes que vislumbra um quociente neurótico bastante intenso na obra de Georges Bataille. Vista como a busca do impossível, tal como se vê em Bataille, a neurose tem lá seu tanto de paradoxal, na medida mesma em que se coloca como uma condição única que permite o escrever e o ler. Daí o caráter contraditório da neurose que faz investimentos na instância emocional do sujeito-escritor que parece tudo fazer para se pôr contra a frustrante busca de um tudo que é, ao mesmo tempo, um nada. É aí que se tem o paradoxo, tal como diz Barthes (1977, p. 10): “Os textos, como os de Bataille - ou de outros - que são escritos contra a neurose, do seio da loucura, têm em si, se querem ser lidos, esse pouco de neurose necessário para a sedução de seus leitores". Nessas considerações pode-se entrever, perfeitamente, a figura de Murilo Rubião.

Mas isso não é tudo que se pode dizer da agonia do escritor no processo de escreverreescrever-cortar-voltar-rasgar. É necessário ir além da palavra escrita, do texto grafado, da voz enunciada, do acontecimento tramado. É necessário ultrapassar o presumido e buscar traços que de alguma forma denunciam a inquietação. Para tanto, impõe-se uma razoável compreensão de alguns elementos importantes. Certamente haverá outros mais, além dos que aqui recorto, mas quero deter-me em dois que fazem parte de um processo técnico na composição da narrativa a fábula e a trama - e em um outro que retira suas forças da instância do inconsciente: o discurso.

No caso dos elementos técnicos, quero apenas sumarizar alguns aspectos que são desenvolvidos por Umberto Eco (1994) em seu livro Seis passeios pelos bosques da ficção.

Assim, o erudito italiano afirma que a fábula nada mais é que a história que se conta. Também chamada de estória, na fábula fazem-se presentes os fatos e acontecimentos que têm lugar numa narrativa que se põe em circulação. Desse modo, a história ou a fábula é que traz 
ao leitor um conjunto de acontecimentos nos quais se envolvem os personagens e esse parece ser aquele primeiro momento prazeroso de que fala Murilo Rubião ao construir suas narrativas.

O segundo elemento seria o enredo, que é o modo como a história é contada. São, portanto, os arranjos que o narrador utiliza para fazer a história chegar ao leitor, nada mais que um modo de colocar a história em movimento. É um aspecto importante, uma vez que é através do enredo que o narrador consegue captar o interesse do leitor e, para tanto, ele utiliza algumas estratégias como desfazer a linearidade da narrativa para que o leitor seja levado a organizar os fatos, ocultar dados que chamem a atenção do leitor pelo inusitado dos acontecimentos, o que também exige uma boa reflexão de quem está lendo, assim como ocorre quando o narrador interpola a sequência normal dos capítulos, exigindo uma disposição do leitor para reorganizálos no nível dos acontecimentos narrados.

Além desses aspectos, um mundo de sugestões é posto à disposição do leitor para que ele vá, paulatinamente, desenhando a história. É por essas razões que o enredo é também chamado de trama e de intriga. No aceno que tais palavras fazem ao leitor, está presente a ideia de enredar, tramar e intrigar, aspectos que, como se pode ver, sugerem um envolvimento muito grande de quem lê.

Delineia-se, desse modo, o trabalho artesanal do escritor que precisa lidar com um material em estado bruto para transformá-lo em originais e insinuantes situações da narrativa. Nem seria preciso dizer que, nesse cenário, o trabalho na linguagem é de vital importância. Aí estão, pois, algumas situações que atormentariam a produção das histórias murilianas, o que justifica aquela "tremenda luta com a palavra", de que fala o escritor, aquele "revirar o texto, elaborar e reelaborar, ir para frente, voltar. Rasgar".

Pode-se deduzir do exposto que o enredo tem a clara intenção de alcançar o leitor, despertando sua atenção e seduzindo-o para que ele se ligue à narrativa que se desenvolve. Não seria demasiado lembrar que a própria forma que Murilo Rubião acolheu para fazer seus contos - a narrativa do fantástico - também funciona como elemento agenciador do interesse do leitor na busca de um entendimento mais claro daquilo que ele vê como uma subversão do real.

Uma outra afirmação de Umberto Eco, importante na caracterização dos mecanismos da fábula e do enredo, diz respeito ao fato de que as histórias infantis, dirigidas a leitores que ainda não têm a experiência de leituras aprofundadas, trabalham apenas a história, sem a preocupação com as maquinações que são postas pelo enredo. Isso significa que o leitor infantil quer saber apenas o que aconteceu e o que vai acontecer, sem fazer reflexões que procurem descortinar o modo como o narrador conta a história. Nessas reflexões, fica clara outra afirmação de Eco, esclarecendo que se pode ter uma narrativa apenas com a história, sem um 
enredo, mas é impossível que se tenha uma narrativa sem história. Afinal, não tem como compor um enredo se não se tem o material que vai ser trabalhado nessa composição, ou seja, se não se tem a história.

Finalmente, destaco o terceiro elemento desse jogo de contrafaces que se projetam na narrativa e que será, sem dúvida, um dos mais importantes operadores da leitura. Refiro-me ao discurso, esse manancial de menções, processos sugestivos e falas segredadas soturnamente que se espalham pelo texto.

O conceito de discurso é amplo, podendo ser focalizado tanto na área dos estudos linguísticos quanto na dos estudos literários. Assim, pode-se falar que o discurso é o resultado de um conjunto de enunciados que se articulam visando à constituição de um todo significativo, podendo-se também conceituá-lo, como Benveniste (apud REIS; LOPES, 1998, p. 110), para quem o discurso é o mecanismo através do qual se produz a comunicação entre as pessoas. Desse modo, quando alguém opera um ato de comunicação com um destinatário, está-se diante de um discurso que emergiu no instante em que um sujeito falante se apropriou da língua.

Como manifestação literária, pode-se dizer que o discurso é uma instância articulada à história e ao enredo, uma vez que resulta da enunciação de um narrador que conta uma história dirigida a um receptor que pode ser o leitor, ou a outro ser dentro da narrativa mas que se limita, quase sempre, a ouvir, sem esboçar qualquer ação ou reação, que é denominado narratário. Segundo Carlos Reis e Ana Cristina Lopes, no discurso ocorrente num texto literário, trata-se "não só de explicar a articulação orgânica dos vários componentes que integram o nível discursivo, mas também de entender a sua projeção semântica, em função da específica história que o discurso representa, a qual solicita o privilégio de determinados signos narrativos, em detrimento de outros" (1998. p. 112).

É importante destacar nessa formulação o anúncio de que o discurso literário privilegia determinados signos narrativos em detrimento de outros, o que se aproxima significativamente da afirmação de Octavio Paz, citada no início deste artigo, para quem "o valor das palavras reside no sentido que ocultam. Ora, este sentido não é senão um esforço para alcançar algo que não pode ser alcançado realmente pelas palavras. Com efeito, o sentido aponta para as coisas, assinala-as, mas não as alcança jamais. Os objetos estão mais além das palavras” (1972, p. 43). Têm-se aí duas coisas importantes que caracterizam o discurso literário: o fato de o valor das palavras residir no sentido que ocultam e o esforço vão das palavras para alcançar, pelo sentido, as coisas.

O que se pode verificar nas afirmações acima é a condição de o discurso literário caracterizar-se como um jogo em que os significantes deslizam, articulando-se para promover 
uma significação que, na ânsia de dizer o impossível, acaba ultrapassando o dito para aninharse no especial lugar das sugestões. Assim, o discurso se compõe a partir de signos que dão a ver significações de modo claro em determinadas situações e, em outras, se insinuam para sugerir significações apenas implícitas, numa formulação que processa o privilégio de alguns signos em detrimento de outros, tal como colocado por Reis e Lopes. E é exatamente no poder insinuador da sugestão que o discurso busca superar as barreiras que insistem em distanciar a linguagem das coisas.

É importante entender que o discurso, justamente porque, algumas vezes, mostra significações claras e, em outras, esconde significações mais evidentes, consegue operar um jogo e um poder de dizer que só o leitor atento, ligado nos escaninhos do texto, consegue detectar a partir das sugestões que ele, discurso, coloca à disposição de quem lê.

Todas essas colocações procuram mostrar que o autor do texto, ao operar o discurso, busca fazer escolhas que querem alcançar aquele mais-dizer que está no seu horizonte criador. Entretanto, como a linguagem sempre insiste em se mostrar avessa a uma completude de significação, muitas vezes o texto escrito fica prenhe de sentidos que mal deixam trair o que atormentava o autor na busca de uma significação contundente. E esse parece ser, à perfeição, o caso de Murilo Rubião na sua angustiante busca do texto perfeito. É nesse caso que os elementos inconscientes, fazendo investimentos no ato de escrever, conseguem, quando não dizer, pelo menos sugerir e é neste momento que o leitor competente pode dar-se conta da aludida significação contundente.

Mas é hora de operacionalizar toda essa teoria, buscando fazê-la emergir de um conto de Murilo Rubião. Tomo, então, “A fila”, narrativa publicada em O convidado. Sua fábula, ou sua história, é simples. Pererico, o personagem central, vem do interior para fazer uma entrevista com o gerente de uma fábrica. Ao chegar ao local, percebe que terá de enfrentar uma longa fila. Quem o recebe e lhe dá instruções é o negro Damião, "elegante, ligeiramente grisalho nas têmporas e de maneiras delicadas" (RUBIÃO, 1974, p. 39). Pererico volta à fábrica várias vezes e sempre encontra a fila enorme, além de notória implicância do atendente que, a cada vez, lhe entrega uma ficha com número mais alto que o das anteriores. Isso o leva a brigar com Damião, mas logo percebe que é preciso reaproximar-se dele, para conseguir falar com o gerente. Nesse meio tempo, conhece Galimene, uma prostituta que se compadece de sua sorte adversa e acaba levando-o para a pensão onde ganha a vida, alimentando-o, assistindo-o, pois o dinheiro de Pererico acabara. Desesperado para voltar ao interior, Pererico deixa de ir todos os dias à fábrica, como fizera até então, relaxa na sua determinação de falar com o gerente até que um dia, lá chegando, encontra o pátio vazio. É o momento em que Damião o fulmina com 
a terrível notícia de que o gerente morrera. Para tornar ainda mais aguda sua perplexidade e sofrimento, pergunta se muitos haviam ficado sem falar com o gerente, tendo como resposta seca: “- Somente você. Nas duas últimas semanas, vendo a aproximação da morte, atendeu a todos que apareceram" (RUBIÃO, 1974, p. 54).

No epílogo da narrativa, vê-se que o personagem, inteiramente desiludido, anulado interiormente, volta a sua cidade. No trem, "olhava a paisagem através da janela. E se alegrou quando viu surgir nas encostas das montanhas os primeiros rebanhos" (RUBIÃO, 1974, p. 56). Consolo derradeiro para um ser emparedado e destruído.

A crítica tem destacado nesse texto a questão da burocracia de que uma fila é sempre um símbolo preciso. Fila é sinônimo de espera, de (im)paciência, de desatenção para com o outro, de mau atendimento e de leniência, sobretudo no serviço público onde ela parece encontrar o seu locus mais expressivo. Murilo Rubião, que foi durante toda uma vida um servidor público, fez várias críticas em sua obra ao caráter moroso do trabalho desenvolvido nas repartições estatais, umas mais veladas e outras bastante contundentes como a que se observa no conto "O ex-mágico da Taberna Minhota", de seu primeiro livro.

Assim, a fabulação de "A fila" ganha ingredientes muito fortes, justamente porque sua trama é composta para mostrar como o domínio de um outro - no caso do conto, o domínio de um ente estatal - representado por indivíduos mal preparados, pode levar à anulação do sujeito, fechando-lhe portas, postergando-lhe contatos e atendimento, desconhecendo o ser humano que tem seus direitos substituídos por favores. E, diga-se, como Murilo Rubião soube fazer isso. Sua trama, bem urdida, é o enredamento do leitor que se vê espelhado no personagem, sentindolhe as angústias e sofrimentos.

Entretanto, é preciso dizer que esse desconforto do leitor, a sua identificação com as atribulações do personagem, provém de algo que está além da narrativa enquanto trama ou enredo. Esse algo além está situado no nível do discurso que, como já se disse, é pródigo na oferta de sugestões. Quer dizer, os significantes que se exibem no nível da fábula ou do enredo deslizam incessantemente, atingindo aquela zona crepuscular em que as significações só são percebidas na forma de indícios, sinais ou vestígios cujo entendimento compete ao leitor produzir. Isso significa que esse dizer ensombrado é, na verdade, aquele mais-dizer a que me referi, que se dá naquela zona nebulosa em que a língua se torna precária, justamente por não conseguir dar conta da realidade exuberante, o que a faz calar-se, só restando produzir um mostrar que se situa no plano da alusão, da sugestão.

É importante dizer que a situação do leitor diante do texto não é de alheamento completo porque, de alguma forma, ele capta aquelas emanações que brotam do escrito. Desse modo, 
mesmo que o leitor nem saiba dos detalhes operativos da língua, ainda que ele não se dê conta das reviravoltas do discurso para tentar dizer o que é impossível, reviravoltas que se manifestam na aludidas formas de sugestões e insinuações, ele acaba sendo alcançado por um dizer que não se manifesta na superfície do texto, mas que está ali, ciciando uma significação que mesmo não sendo apreendida na sua inteireza consegue, no mínimo, provocar um mal-estar que incomoda o leitor, numa espécie do sintoma psicanalítico que se manifesta porque está em busca de uma significação.

Esse dizer que não se mostra na sua inteireza, isto é, que não aparece na materialidade da letra, é algo semelhante ao que se passa no nível do mito, essa narrativa misteriosa que esconde, nos escaninhos de suas fábulas, persuasivas moções de equilíbrio emocional que alcançam o sujeito pela via do inconsciente.

No caso do conto "A fila”, pode-se perceber o mal-estar que sai do personagem e alcança o leitor, na forma de uma angústia que vai gradativamente aumentando de intensidade para pôr à mostra um sujeito que caminha na direção de uma situação inevitável. E isso é acentuado, sobretudo, porque, em nenhum momento, são oferecidas explicações ao leitor. Este não sabe quem é Pererico, de onde ele vem, o que veio conversar com o gerente da fábrica, qual a natureza de sua missão, que outros indivíduos ou interesses estariam envolvidos na questão e, afinal, por que razões ele insiste em não dizer ao atendente Damião o assunto que queria tratar com o gerente. Esse cenário misterioso é mecanismo decisivo para acionar a angústia do leitor.

Procuro, então, fazer uma reflexão que possa explicar esses aspectos apenas insinuados pelo texto, aspectos que, na verdade, constituem o mais-dizer que se coloca além do que está escrito na narrativa. A propósito, diga-se que esse é o papel do crítico ou do analista a quem cabe analisar o discurso para desentranhar dele o que foi apenas sugerido ou insinuado. Sua função é, pois, de colaborar para tornar claro ao leitor aquilo que ele, leitor, sentiu sem conseguir identificar ou nomear.

Destaco, logo de início, que o tom que percorre a narrativa de Murilo Rubião está nitidamente marcado pelo timbre do trágico. Johnny Mafra mostra que o conflito trágico caracteriza-se por "ações que, por fazer prevalecer a vontade sobre situações convencionais, levam o homem à desgraça, porque, mesmo movidas pela vontade, são ações de um ser limitado" (2010, p. 70). Essa é a nota dominante do animal trágico que é o homem: o confronto que se estabelece entre a sua limitação e a superioridade das forças cósmicas que o dirigem. Quer dizer, o homem está envolvido por uma condição que o coloca à mercê dos deuses, marcado por um destino contra o qual não se pode lutar porque não há forças que possam modificá-lo. 
Essa dimensão tem presença marcante na tragédia grega em que as ações dos personagens evoluem no sentido de passarem pelo reconhecimento de uma situação inusitada e desconhecida, do que decorre a peripécia, a mudança de seu destino no contrário daquilo que até então tinha lugar. Daí à catástrofe é um pequeno salto.

Essa atmosfera acompanha toda a narrativa de "A fila". A sonegação de informações tem um duplo destaque no conto: inicialmente, ela se dá com o personagem que não consegue qualquer avanço em sua pretensão de falar com o gerente da fábrica, sobretudo porque o recepcionista Damião lhe subtrai qualquer esclarecimento. Em segundo lugar, vem a grande sonegação, a que ocorre no enredo e que envolve o leitor, pois não deixa nada claro quanto aos acontecimentos. Assim, a impotência trágica alcança todos os espaços da narrativa, apontando para um porvir inimaginável e amedrontador. É esse espírito que envolve o leitor e o torna uma espécie de parceiro do personagem na angústia e no sofrimento.

Os mecanismos do reconhecimento e da peripécia têm ocorrência rápida e simultânea na narrativa. Pererico passa do ignorar ao conhecer quando, ao chegar certo dia à fábrica, encontrando os pátios vazios e a situação de abandono, toma conhecimento de que o gerente morrera e que ele acabou sendo o único que não fora atendido. A devastação que o atinge é a própria peripécia. Afinal, o personagem, de alguma forma, ainda alimentava a esperança de ter a tão sonhada entrevista, sobretudo depois do amparo e dos estímulos de Galimene, mas a morte do gerente era o sepultamento de toda e qualquer expectativa. A sorte de Pererico estava definitivamente selada.

Para caracterizar mais objetivamente os recursos usados por Murilo Rubião na produção do conto, quero lembrar que, no nível do enredo, o escritor trabalha a sutileza de alguns mecanismos como a já mencionada sonegação de informações que, aparentemente importante para o personagem, é essencial para alcançar o leitor e torná-lo sujeito desconfortado diante de fatos que exigiam esclarecimentos para sua elucidação. O relaxamento a que o personagem se entregou - deixando de comparecer diariamente na fábrica - é outro ingrediente que faz o maior sentido diante de uma realidade de negações que lhe desenham claramente sua condição de ser submisso, emparedado e derrotado. É como se Pererico chegasse à compreensão de que pouco adiantaria lutar contra um ente inalcançável que só se mostrava através de prepostos radicais e insensíveis. Para além do personagem, tudo isso contribui para ir trabalhando o desconforto do leitor e para minar as suas esperanças quanto à superação que ele esperava de um ser humano subjugado. Aliás, diga-se que é o nível do leitor que o escritor quer alcançar, razão pela qual o jogo especular personagem-leitor é o ingrediente que aciona os mecanismos do trágico que, indiscutivelmente, se faz presente no nível do discurso. Aqui, inclusive, cabe a observação de 
que nem se deve indagar se o escritor tinha consciência de que trabalhava tais aspectos, pelo fato mesmo de que a pergunta é absolutamente irrelevante. É até mais provável que Murilo Rubião nem tenha pensado em inserir tais elementos em sua narrativa mas o fato é que eles estão lá, sobretudo porque eles fazem parte não apenas de um arcabouço cultural que estrutura as preocupações e sofrimentos humanos mas, principalmente, porque se inserem no ser humano que está marcado por um terrível registro que o autentica como ser precário, que pode ser traduzido na inafastável angústia do "viver para morrer". Fazendo parte desse universo, todos subsumimos que estamos à mercê de acontecimentos inesperados, que não precisam se anunciar e que são absolutamente inevitáveis.

Desse modo, os elementos inconscientes que, ininterruptamente, fazem investimentos em todas nossas ações e procedimentos, agem de maneira soberana, tornando-nos presas de manifestações que, muitas vezes, nem conseguimos explicar. Hoje, é possível saber que as coisas se passam assim, desde que um médico vienense retirou o homem do centro de si mesmo para mostrar-lhe que há forças poderosas que brotam do seu interior e conduzem seu destino. Vejam-se, a respeito, as palavras do psicanalista Antônio Teixeira (2015, s.p.):

Ao se alterar a configuração discursiva do mundo, podemos fazer existir maximamente o que antes não estava reduzido a nada, ao mesmo tempo em que notamos reduzir-se a quase nada o que antes tinha máxima existência. É o que fez Freud, como vocês sabem, com a psicologia de seu tempo. A consciência que antes tinha intensidade existencial máxima, na fenomenologia de Husserl e Jaspers, apaga-se na mesma medida em que Freud vem iluminar o campo das formações do inconsciente.

É por isso que os investimentos inconscientes têm tanta importância na produção da obra literária. Através deles, o escritor diz muito do que quer mas, sobretudo, do que nem desconfia estar dizendo. E é também através deles que consegue tocar tão profundamente o seu leitor, na medida em que alcança dimensões imprevistas que só podem ser ditas quando um universo de sugestões flui na escrita, num querer dizer o texto impossível mas que, mesmo assim, acaba transferido ao leitor pela via do inconsciente. É exatamente isso que me parece ocorrer com “A fila”. Murilo Rubião, conscientemente ou não, inoculou em seu texto indeléveis traços do trágico, numa configuração que consegue, inclusive, transformar aquele aparente final agradável quando, no trem, de volta para casa, o personagem "olhava a paisagem através da janela. E se alegrou quando viu surgir nas encostas das montanhas os primeiros rebanhos" (RUBIÃO, 1974, p. 56). Por tudo que se vê no conto, é lícito supor que as palavras finais são uma espécie de lembrança encobridora daquela catástrofe que está próxima de acontecer: a 
derrocada do sujeito irremediavelmente abatido pelas forças de um destino que ele ousou desafiar.

\section{Referências}

BARTHES, Roland. O prazer do texto. Tradução de. J. Guinsburg. São Paulo: Editora Perspectiva, 1977.

ECO, Umberto. Seis passeios pelos bosques da ficção. Tradução de Hildegard Feist. São Paulo: Companhia das Letras, 1994.

MAFRA, Johnny José. Cultura clássica grega e latina: temas fundadores da literatura ocidental. Belo Horizonte: Editora PUC Minas. 2010.

PAZ, Octavio Paz. Signos em rotação. Tradução de Sebastião Uchoa Leite. São Paulo: Perspectiva, 1972.

REIS, Carlos e LOPES, Ana Cristina M. Dicionário de narratologia. Coimbra: Livraria Almedina, 1998.

RUBIÃO, Murilo. Entrevista a J. A. de Granville Ponce. In: Paulo: Ed. Ática, 1981. O pirotécnico Zacarias, São

TEIXEIRA, Antônio. "A verdade extra-moral de Nietzsche a Freud". Conferência no II Colóquio Internacional Nietzsche, Pessoa, Rosa, Freud, Belo Horizonte: PUC Minas, 2015. 


\section{"Petúnia", de Murilo Rubião, e o diálogo com os contos populares "Petúnia", by Murilo Rubião, and its dialogue with popular tales}

\begin{abstract}
RESUMO: É incontestável a contribuição de Murilo Rubião para a literatura brasileira, em específico quando tratamos da literatura fantástica. Rubião nos insere em um universo insólito, impulsionando-nos a pensar e repensar sobre como sua literatura é impactante para os leitores e também para aqueles que a estudam. Nesta proposta, analisaremos o conto "Petúnia", do referido escritor mineiro, trazendo diálogos possíveis com os mitos e com os contos de fadas tradicionais, de Charles Perrault, Irmãos Grimm, Hans Christian Andersen, Joseph Jacobs e também com os contos populares, como "A menina enterrada viva". Esses diálogos são embasados pela noção de intertextualidade, especialmente, a tratada pela estudiosa Júlia Kristeva. Ademais pretendemos demonstrar como Murilo Rubião transgride com a literatura por meio da irrupção do fantástico, e como tal irrupção sugere a transgressão dos padrões sociais.
\end{abstract}

PALAVRAS-CHAVE: Literatura fantástica. Murilo Rubião. Intertextualidade. Transgressão. Contos populares.

\begin{abstract}
Murilo Rubião's contribution to the Brazilian literature is undeniable, in particular when we talk about the fantastic literature. Rubião introduces us to an unusual universe, leading us to think and rethink about how his literature is impressive to both readers and scholars os his work. In this article, we analyze his tale "Petúnia," alluding to possible dialogues with myths and fairy tales by Charles Perrault, the Brothers Grimm, Hans Christian Andersen, and Joseph Jacobs as well as with popular tales, such as "A menina enterrada viva." Such dialogues are supported by the notion of intertextuality, especially as defined by Julia Kristeva. In addition, we show how Murilo Rubião transgresses the literature through the irruption of the fantastic, and how this irruption suggests the transgression of social standards.
\end{abstract}

KEYWORDS: Fantastic literature. Murilo Rubião. Intertextuality. Transgression. Popular tales.

Como obra de arte, não se podia encontrar nada de mais admirável do que a pintura em si. (Edgar Allan Poe)

\section{Primeiras palavras}

Ao pegarmos em nossas mãos o livro intitulado Murilo Rubião: obras completas (2010) editado pela Companhia de Bolso, sentimos a necessidade de perguntar: como um autor

\footnotetext{
* Doutoranda em Estudos Literários na Universidade Federal de Uberlândia - UFU, com início no ano de 2017. Mestre em Estudos Literários pela Universidade Federal de Uberlândia - UFU. Especialista pela Universidade Federal do Triângulo Mineiro - UFTM (2009) no curso de Pós Graduação "Lato Sensu" Especialização em Crítica Literária e Ensino de Literatura. Graduada em Letras, com licenciatura pela em Português/Inglês e suas respectivas literaturas pela Universidade Federal de Uberlândia - UFU (2007). Vice-líder do Grupo de Pesquisas em Espacialidades Artísticas/CNPq e integrante do grupo de estudo Nós do insólito: vertentes da ficção, da teoria e da crítica - UERJ. Estudos com ênfase no espaço literário, narrativa fantástica, com interesse especial sobre a obra do escritor Graciliano Ramos.
} 
aclamado pela crítica literária brasileira pode ter escrito somente 33 contos ao longo de toda a sua vida? "Inocência" à parte, Murilo Rubião não precisaria ter escrito mais contos do que aqueles que escreveu para ser aclamado e considerado o precursor da literatura fantástica brasileira. Antonio Candido em seu ensaio "A Nova Narrativa", que faz parte de seu livro $A$ educação pela noite (1989), já nos dizia quem é o escritor Murilo Rubião:

Com o livro de contos $O$ ex-mágico (1947), (Murilo Rubião) instaurou no Brasil a ficção do insólito absurdo. Havia exemplos anteriores de outros tipos de insólito, sobretudo de cunho lírico, haja vista o admirável conto "O iniciado do vento", de Aníbal Machado, um dos escritores mais finos da nossa literatura moderna, formado no Modernismo e se expandindo a partir dos anos 40 (CANDIDO, 1989, p. 207).

A grandiosidade da obra deixada por Murilo Rubião não está na quantidade da mesma e sim no fascínio criado pelas suas narrativas em nós, leitores. Esse fascínio é impulsionado por sentimentos de estranhamento, não-lugar, indefinição, e, como nos afirmou Candido, as narrativas de Rubião são permeadas pelo sentimento do absurdo. Não sabemos onde estamos "pisando" quando se trata da obra de Murilo Rubião.

Pensando nesse campo minado que é a literatura de Murilo Rubião, ousamos neste texto trabalhar os diálogos possíveis entre o conto "Petúnia" e alguns contos de fadas tradicionais, como "Barba Azul” de Charles Perrault, "Rapunzel”, dos Irmãos Grimm, "João e o pé de feijão" de Joseph Jacobs, além da narrativa popular “A menina enterrada viva”, que faz parte do livro Contos tradicionais do Brasil de Câmara Cascudo.

De acordo com J.R.R.Tolkien: "o reino dos contos de fadas é amplo, profundo e alto, cheio de muitas coisas: lá se encontram todos os tipos de aves e outros animais; oceanos sem praias e estrelas sem conta; uma beleza que é encantamento e um perigo sempre presente; alegria e sofrimento afiados como espadas" (TOLKIEN, 2013, p. 3). Tolkien, em seu ensaio "Sobre contos de fadas", mostra-nos que os contos de fadas vão além das características das tradicionais narrativas nas quais, em sua maioria, apresentam a marcação frásica "Era uma vez" iniciando as mesmas, como podemos constatar nos contos de Charles Perrault: "Cinderela", "Pele de Asno", "O pequeno Polegar", "Barba Azul”; nos dos Irmãos Grimm: "Branca de Neve", "Chapeuzinho Vermelho", "Rapunzel”, de Hans Christian Andersen: “A princesa e a ervilha", de Joseph Jacobs: “João e o pé de feijão" e "A história dos três porquinhos". Além disso, Tolkien elucida que um conto de fadas não precisa ter necessariamente as figuras das fadas madrinhas, princesas em perigo e príncipes corajosos e dispostos a salvar belas princesas. Para Tolkien, a principal característica de um conto de fadas é a magia. 
Pode-se dizer que há uma magia presente no conto "Petúnia" de Murilo Rubião, uma magia que nos insere em um mundo permeado pelo insólito, mas que nos faz refletir sobre a nossa realidade prosaica, conforme afirma a estudiosa Gama-Khalil ao tratar de uma das narrativas rubianas: "o que o leitor encontra nesses contos é esse sentimento inusitado que advém de uma estranheza não especificamente do fantástico que surge nas narrativas, mas de perceber que esse inusitado, esse insólito, ao mesmo tempo tão desumano é marcado por náuseas e estranhezas" (GAMA-KHALIL, 2016, p. 49).

\section{"Petúnia": nos fios da trama}

O conto "Petúnia narra a história de um homem chamado Éolo que nunca havia se interessado em casar: "Éolo não tinha planos para casamento" (RUBIÃO, 2010, p. 184). Éolo é criado por uma mãe que podemos caracterizar como uma mulher muito protetora e controladora das atitudes de seu filho e, sendo assim, ela possuía esperança de vê-lo casado, dando-lhe netos, para que eles fizessem bom proveito do dinheiro que ela iria deixar após sua morte: "Sou rica e só tenho você. Não admito que minha fortuna vá para as mãos do Estado. Quero que ela fique com os meus netos!” (RUBIÃO, 2010, p. 184).

Dona Mineides - mãe de Éolo - promove constantes festas para o filho conhecer alguma moça que o interesse e assim casar-se com ela. De tanto insistir no casamento do filho, Dona Mineides resolveu escolher ela mesma a esposa para o seu filho:

- É ela. Não se lembraria em seguida de ter ouvido o nome de Cacilda, talvez por surpresa do encontro. O rubor subiu-lhe à face, ele que de ordinário mostrava-se seguro de si ou indiferente no trato com as mulheres. Ficou a contemplar em silêncio os olhos castanhos e grande, os lábios carnudos, os cabelos longos da desconhecida. Vagaroso, aproximou-se dela e a tomou-a nos braços. (RUBIÃO, 2010, p. 185)

Éolo enfim se apaixona pela escolhida de sua mãe - Petúnia - com quem teve três filhas. As três filhas aparecem inesperadamente mortas. Éolo, vendo-se preso nessa teia de incongruências, pois a mulher afirma que foi o retrato da sogra que havia matado suas filhas, acaba matando sua esposa e enterrando-a, juntamente com suas filhas no quintal de sua casa.

\section{Era uma vez o fantástico rubiano}

O conto "Petúnia" de Murilo Rubião intriga-nos, logo no início, pelo seu título. Quem é Petúnia? Uma flor? Uma mulher com nome Petúnia? O jogo semântico realizado por Rubião já nos insere no campo do insólito assim que nos deparamos com o conto em nossas mãos. 
Petúnia é a mulher com a qual se casa Éolo. Ao longo do conto essa mulher muda de nome, passando a se chamar Cacilda: “- Chamo-me Cacilda. Nenhuma delas se chama Petúnia gritava a mulher" (RUBIÃO, 2010, p. 183). Se buscarmos compreender o significado da flor petúnia e sua simbologia, vamos constatar que se trata de uma planta híbrida, de cor vermelha, que é simbolicamente conhecida por ser uma flor da transformação e da sabedoria. Logo, cumprindo seu papel simbólico, a mulher Petúnia se transforma em Cacilda e será essa mulher a responsável pelos acontecimentos insólitos e mórbidos que permeiam a narrativa.

Com relação ao nome Cacilda, buscou-se compreender a origem do nome e descobriuse que há uma santa do cristianismo importante com esse nome. De acordo com a tradição, Cacilda visitava doentes e presos cristãos, levando sempre uma cesta de pães para eles. A tradição ainda afirma que, quando Cacilda era parada por guardas, os pães transformavam-se em flores e, quando Cacilda entrava na cadeia, as flores se transmutavam novamente em pães. Por causa de sua crença - cristianismo - Cacilda foi condenada à prisão a pedido de seu próprio pai e morta. Como podemos observar, a transformação está presente na história da Santa Cacilda, fato esse que vai ao encontro da transformação da personagem de Rubião: Petúnia para Cacilda. Petúnia, nesse sentido, assinala sua figuração metamórfica desde o nome.

Relevante apontar que o escritor de literatura fantástica, Robert W. Chambers, publicou em 1895 o livro $O$ rei de amarelo, uma narrativa permeada pelo gótico e que nos apresenta como uma de suas personagens a Rainha Cassilda. É oportuno dizer que Murilo Rubião era conhecido por ter sido um grande leitor, o que pode tê-lo instigado a dar o nome de sua personagem de Cacilda ao rememorar do livro de Chambers, aproveitando-se de toda atmosfera gótica nele existente, como veremos adiante.

Enquanto é nomeada como Petúnia, a personagem assume características de uma mulher boa, afetuosa, compreensiva, disposta a agradar o marido Éolo em todos os seus desejos, tanto que aceita ter o retrato da sogra exposto em seu quarto e de Éolo:

A mãe não presenciou o casamento. Antes de morrer, manifestou o desejo de ver seu retrato transferido da sala de jantar para os aposentos que iriam abrigar o casal. Petúnia apressou-se em concordar, enquanto Éolo, consciente dos motivos que levaram a moribunda a expressar o estranho pedido, hesitava em dar sua aquiescência. (RUBIÃO, 2010, p. 185)

Vendo que o marido Éolo havia perdido a mãe tão cedo, Petúnia não hesita em ser uma boa pessoa e mulher, atendendo ao pedido de sua sogra, tanto que essa postura pode ser averiguada pelo verbo "apressar". Petúnia nem ao menos cogita em recusar o pedido da sogra 
morta e nem o do marido, ela é compreensiva e parece que jamais sairia dessa sua postura passiva.

Essa mesma postura passiva e compreensiva pode ser verificada no conto "Cinderela ou O sapatinho de vidro" de Charles Perrault, quando temos a descrição da Gata Borralheira:

A pobre menina suportava tudo com paciência. Não ousava se queixar ao pai, que a teria repreendido, porque era sua mulher quem dava as ordens na casa. Depois que terminava seu trabalho, Cinderela se metia num canto junto à lareira e se sentava no meio das cinzas. Por isso, todos passaram a chama-la Gata Borralheira. Mas a caçula das irmãs, que não era tão estúpida quanto a mais velha, começou a chamá-la Cinderela. (PERRAULT, 2010, p. 19-20)

Assim como Petúnia, a Cinderela é compreensiva apesar de todos os trabalhos domésticos que precisa fazer a mando de sua madrasta, mesmo com todas as humilhações e pedidos mais impróprios e descabidos. Nos contos de fadas tradicionais, é muito comum, então, termos a postura passiva das personagens femininas e Petúnia, no início do conto segue esse estereótipo.

Toda a atitude tranquila e paciente de Petúnia começa a se modificar quando o retrato da sogra pendurado em seu quarto começa a se desfazer em uma determinada noite:

\footnotetext{
Alguns dias após o último parto, aterrorizada, Petúnia acordou o marido:

- Olha, olha o retrato!

Éolo demorou a entender por que fora despertado de maneira tão repentina. Finalmente compreendeu a razão: a maquilagem da mãe se desfazia no quadro, escorrendo tela abaixo. Levantou-se resmungando. Com a ajuda de batom e cosméticos retocou o rosto de dona Mineides.

- Pronto - disse. O sorriso demonstrava sua satisfação pelo trabalho realizado. Petúnia fez uma cara de nojo e virou-se para o canto.

Custou a reencetar o sono interrompido. Por mais que tentasse esquecer a cena, tinha o pensamento voltado para o retrato da sogra a derreter-se a moldura e o assoalho. (RUBIÃO, 2010, p. 186)
}

É no momento em que o retrato da mãe de Éolo começa a se desfazer na tela que Petúnia começa a se transformar em Cacilda, porque é Cacilda que não aceita a intervenção da sogra em sua vida conjugal, apesar de ter sido a sogra quem a havia escolhido como esposa de Éolo.

Se, antes em vida, dona Mineides queria controlar todos os passos de seu filho, morta, ela não deixa de agir e sua ação começa com a necessidade de seu retrato ser sempre retocado pelo seu filho. Acreditamos que o fato de o quadro de Mineides desfazer-se implica o sentido de que ela, mesmo morta, exige atenção por parte do filho e da nora, mantendo-os subservientes, como escravos seus. 
Essa constante intrusão de mães e madrastas na vida dos filhos é uma temática recorrente nos contos de fadas tradicionais, como podemos constar anteriormente em "Cinderela" e também em "João e Maria” e "A princesa e a ervilha". Vejamos a seguir:

\begin{abstract}
"Ouça-me", sua mulher respondeu. "Amanhã, ao romper da aurora, vamos levar as crianças até a parte mais profunda da floresta. Faremos uma fogueira para elas e daremos uma crosta de pão para cada uma. Depois vamos tratar dos nossos afazeres, deixando-as lá sozinhas. Nunca entrarão o caminho de volta para casa e ficaremos livres delas. (GRIMM, 2010, p. 161).
\end{abstract}

Uma noite, uma tempestade terrível desabou sobre o reino. Raios chispavam, trovões roncavam e chovia a cântaros - realmente pavoroso! Inesperadamente, ouviu-se uma batida no portão da cidade, e o rei em pessoa foi abri-lo. Havia uma princesa parada lá fora. Mas valha-me Deus! Que figura ela era debaixo daquele aguaceiro, sob um tempo daqueles! A água escorria pelo seu cabelo e suas roupas. Jorrava pelas pontas dos sapatos e entrava de novo pelos calcanhares. E, mesmo assim, ela insistiu que era uma verdadeira princesa.

"Bem, isso é o que vamos ver, daqui a pouco!" pensou a rainha. (ANDERSEN, 2010, p. 247-248)

A madrasta de João e Maria, assim que surgiu a oportunidade, sugeriu que as crianças fossem deixadas na floresta e, assim, ela e o marido ficariam sem "o peso" de criá-los. A rainha, mãe do príncipe na história de Andersen, duvida que qualquer mulher seja boa o suficiente para seu filho, até mesmo uma verdadeira princesa. Ela fará de tudo para testar essa princesa e ver se ela é realmente a pessoa certa para casar com seu filho, o príncipe. Essas duas figuras maternas dos contos de fadas tradicionais muito se assemelham à mãe de Éolo no conto de Murilo Rubião. Todas querem decidir a vida de seus filhos conforme suas crenças, valores. Relevante apontarmos como a construção daquilo que compreendemos hoje por "ser sogra" foi sendo paulatinamente construído ao longo dos séculos e como essas características foram moldadas, transformadas e, de certa forma, expandidas para o imaginário das pessoas. Conforme explica Foucault (2000, p. 112), “um enunciado tem sempre margens povoadas de outros enunciados" e Rubião propicia que seu conto transborde de enunciados em um movimento intertextual e reatualize sentidos.

O fato de o retrato de dona Mineides constantemente desconfigurar-se e necessitar de retoques foi instigando a transformação de Petúnia em Cacilda:

A repetição do fato nas noites subsequentes aumentou, o desespero dela. Suplicava ao esposo que retirasse o quadro da parede. Éolo fingia-se desentendido. Pacientemente recompunha sempre a pintura da velha.

Houve um momento em que Petúnia descontrolou-se:

- Como é possível amar, com essa bruxa no quarto? 
As relações entre os dois, aos poucos, tornavam-se frias, sem que deixassem de compartilhar a mesma cama. Quase não se falavam, os corpos distantes, nunca se tocando. Cacilda lhe dava as costas e entediada lia um livro qualquer. Também descuidava das filhas e muitas vezes as evitava. (RUBIÃO, 2010, p. 186)

Se antes Petúnia, sem hesitar ou questionar, aceitou o pedido da sogra de ter o seu retrato pendurado no quarto do casal, agora, ela não quer mais vivenciar essa desconfigurarão do rosto de dona Mineides. Há um desconforto, uma angústia e até um desespero de ver a cena de decomposição do retrato da sogra. O retrato projeta-se ficcionalmente como continuação da intervenção da sogra na vida de filho; é um retrato que se decompõe assim como o casamento de Éolo, tanto que sua amada não é mais Petúnia e sim Cacilda. É Cacilda quem ele encontra sentada no quarto do casal, desconsolada com a morte de suas três filhas pequenas:

Éolo acabava de entrar em casa, vindo da cidade, quando sentiu o corpo tremer; afrouxarem-lhe as pernas, a náusea chegando à boca: jogadas no sofá, as três Petúnias jaziam inertes, estranguladas. Cambaleante, deu alguns passos. Depois retrocedeu, apoiando-se de encontro à parede. Transcorridos alguns minutos, superou a imensa fadiga que se entranhara nele e pôde observar melhor as filhas. Quis reanimá-las, endireitar-lhes os pescocinhos, firmar as cabecinhas pendidas para o lado.

Percebeu a inutilidade dos seus esforços e rompeu-se num pranto convulsivo. Não entendia por que alguém poderia ter feito aquilo. De repente tudo se aclarou e saiu à procura de Cacilda. Encontrou-a sentada na cama, segurando a cabeça nas mãos. (RUBIÃO, 2010, p. 186-187)

Como se percebe no excerto anteriormente citado, Éolo encontra suas três filhas mortas, estranguladas no sofá e sua primeira suspeita do crime é sua esposa Cacilda. Enquanto isso, Cacilda culpa o retrato da sogra: “- Foi ela, a megera. - A voz era inexpressiva, sumida. O dedo apontava o retrato da velha a se desmanchar na tela" (RUBIÃO, 2010, p. 187).

Quem matou as três meninas? Cacilda? O retrato de sua sogra? Cacilda poderia ter matado as próprias filhas para culpar o marido, para que ele desse mais atenção a ela em vez de ficar dando atenção ao retrato da sogra toda vez que ele se desfizesse. As três meninas também poderiam ter sido mortas pelo retrato da avó, uma vez que ele tem a capacidade de desfigurarse, saindo até mesmo da moldura do quadro, ou seja, o quadro teria poderes mágicos. Quem poderia afirmar que um retrato que se desfaz e se recompõe por meio de uma simples maquiagem não poderia matar? Permanecemos no campo da indefinição, da incerteza e além do mais, tendemos a hesitamos. De acordo com Todorov, em seu livro Introdução à literatura fantástica (2008), “o fantástico ocupa o tempo da incerteza” (TODOROV, 2008, p. 15), e uma das primeiras condições para que haja a irrupção do fantástico é a hesitação: "a vacilação do leitor é pois a primeira condição do fantástico" (TODOROV, 2008, p. 19). 
Nesse momento da morte das três filhas de Éolo e Cacilda, podemos fazer um paralelo com o conto "O pequeno Polegar" de Perrault, quando o ogro mata suas sete filhas após confundi-las com o Pequeno Polegar e seus irmãos:

Em seguida foi até a cama das filhas, onde apalpou os gorrinhos dos meninos: "Ah! Aqui estão eles, os marotos. Não vamos pensar duas vezes." Dizendo estas palavras, cortou sem vacilar o pescoço das sete filhas. Muito satisfeito, voltou a se deitar ao lado da mulher. (PERRAULT, 2010, p. 71)

O Pequeno Polegar, muito esperto, pensando que o ogro não aguentaria ver os seus irmãos e ele dormindo em sua casa sem comê-los, troca os gorros das filhas do ogro de lugar para a sua cabeça e as de seus irmãos, e assim eles conseguem sair vivos da casa do ogro. $\mathrm{O}$ ponto que queremos destacar refere-se à temática da morte dos filhos, a qual é utilizada por Murilo Rubião e transformada para a atualidade em que escreve seu conto. Outro aspecto que se delineia na leitura de Rubião: Será que a possível autora da morte das crianças, Cacilda, queria realmente matar suas filhas? O ogro do conto de Perrault cometeu um erro devido ao desejo incontrolável de comer Polegar e seus irmãos; quanto a Cacilda, ela poderia ter matado as filhas devido ao desejo por atenção do esposo.

Após a morte das filhas, Petúnia é Cacilda definitivamente, não mais retorna ao que fora anteriormente quando do início de seu encontro com Éolo: "Éolo ignorou a pergunta, já convencido de que sempre amara Petúnia, porque na sua frente estava Petúnia" (RUBIÃO, 2010, p. 185). Nunca mais Éolo viu Petúnia, agora em sua vida, somente há Cacilda. Cacilda se transformou em um outro sujeito, não mais submisso, humilde e não mais acatava os desejos de Éolo: "Cacilda retornou tarde. Não deu explicações do que se passara, nem justificou sua ausência; Daí por diante, Éolo habitou-se às constantes fugas da esposa, que saía de manhã e só regressava com o sol-posto" (RUBIÃO, 2010, p. 187).

A figura do que é ser feminino ganha outra dimensão no conto de Rubião, a partir do momento em que ele altera a personalidade de Petúnia para Cacilda, ele reestrutura todas as concepções do que compreendemos como o sujeito feminino delineado pelos contos de fadas tradicionais e pela cultura ocidental: delicado, submisso, cordeiro. Cacilda tem opinião, não quer mais o retrato da sogra no quarto, chamando-a de bruxa, é capaz, talvez, de matar suas próprias filhas para ser o centro da atenção do marido.

Enquanto Cacilda agora "ganha" a ruas, sai de sua casa em "constantes fugas", sem dar explicação onde vai e com quem vai sair, é Éolo que fica preso dentro de sua casa e mais que isso: Éolo é vigiado pelos cavalos-marinhos. A casa vira sua torre. Éolo seria a Rapunzel de 
Rubião: "Por muito tempo Éolo se absteve de sair de casa, temeroso da fúria dos cavalosmarinhos. Impossibilitado de saber o que se passava lá fora, através das janelas hermeticamente trancadas, vagava pelos quartos, afogava-se na tristeza" (RUBIÃO, 2010, p. 187). E somente uma fuga é o que tira Éolo de dentro de sua torre vigiada.

Murilo Rubião brinca com os gêneros, subverte padrões e nos permite ir além do que reconhecemos como contos de fadas. Podemos dizer que ele caminha lado a lado com Tolkien, porque ambos constroem as suas próprias percepções de mundo, um mundo em que a irrupção do fantástico exagera, hiperboliza a realidade prosaica e nos permite caminhar em outros mundos, mundos em que Petúnias são também Cacildas.

Éolo não aguenta mais viver preso em sua casa, fugindo quando os cavalos-marinhos não o estão vigiando. Enfim, busca se libertar matando Cacilda:

Mesmo contra a sua vontade, não conseguia abandonar o leito sem descobrir o corpo da esposa, muito menos desviar os olhos da flor. Na impossibilidade de livrar-se daquela presença obcecante, procurou a faca com que decepara a flor negra da primeira vez e enterrou-a em Cacilda. (RUBIÃO, 2010, p. 188)

Infeliz, encarcerado em sua própria casa, Éolo mata sua esposa Cacilda, uma pessoa na qual ele não consegue mais enxergar a Petúnia que ele tanto amara e que era a mulher mais perfeita que conhecera.

Éolo, ao ficar encarcerado em sua própria casa, remete-nos intertextualmente à própria narrativa mítica de Eolo, deus dos ventos:

Homero e Virgílio estabelecem a morada dos ventos nas ilhas Eólias, entre a Sicília e a Itália. Como rei lhes dão Éolo, que os retém em profundas cavernas. [...]

$\mathrm{Na}$ Odisséia, ele comete a imprudência de encerrar uma parte dos Ventos em barris que manda a Ulisses; ao abri-los os companheiros do herói, uma tempestade se desencadeia e se submergem os navios.

Na Eneida, Éolo, para agradar a Juno, entreabre com um golpe de lança o flanco da montanha sobre a qual repousa o seu trono. Assim que descobrem essa saída, os ventos se escapam e agitam o mar. Mas Éolo não tem tempo de se aplaudir: Netuno, que desdenha de castigar os Ventos, reenvia-os ao seu senhor, em termos cheios de desprezo, e os encarrega a eles próprios de lembrar a Eolo a sua insubordinação. (COMMELIN,1983, p. 97, grifos do autor)

Por meio da citação supracitada, podemos afirmar, embasados em Júlia Kristeva (2005), que todo texto é um mosaico de citações, ou seja, que um "significado poético a outros significados discursivos, de modo a serem legíveis no enunciado poético vários outros discursos" (KRISTEVA, 2005, p. 185). 
Ainda pela citação anterior do conto de Rubião, não podemos deixar de propor um diálogo com conto "Barba Azul", uma das narrativas mais emblemáticas quando se trata do assassinato de esposas pelos seus maridos. Nesse conto, Barba Azul possui o costume de matar suas esposas e depositar o corpo das mesmas em um quartinho trancado com uma chave mágica. A temática se assemelha, mas em condições de produção diferentes e suscitando questões também diferentes. Barba Azul parece ter prazer em matar suas esposas, enquanto Éolo se vê em um jogo, em que a jogada final seria matar sua esposa. No conto de Barba Azul, a mulher é a vítima e o homem seu algoz, mas no conto de Rubião não se tem a certeza de quem seria de fato a vítima. Assim, essa intertextualidade mostra ser uma "absorção de uma multiplicidade de textos (e sentidos) na mensagem poética, que sob outros ângulos, apresentaria como focalizada por um sentido" (KRISTEVA, 2005, p. 185).

Éolo fica preso em um labirinto grotesco e pérfido criado inicialmente por sua mãe e esposa, culminando em seu próprio desespero, o qual acaba transformando-o em um assassino. Nesse labirinto, Éolo precisa esconder o corpo da esposa, desenterrar as filhas, que agora dançam no jardim, e maquiar o quadro desfigurado do retrato de sua mãe.

O labirinto de Éolo é sem saída, porque ele precisa constantemente refazer todas as suas ações, sendo as mesmas infinitas. Nesse instante, podemos vislumbrar um diálogo intertextual com o mito grego de Sísifo, que foi retomado em uma série de ensaios de Albert Camus (2010). Sísifo é condenado a levar uma pedra até o alto da montanha, porém, todas às vezes, que chega ao topo da montanha, a pedra rola montanha abaixo, e Sísifo precisa recomeçar sua tarefa. É um ciclo sem fim.

Assim, acreditamos que Éolo está em um labirinto das aparências, pois não pode deixar nenhum de seus vizinhos descobrir que seu casamento faliu, que suas filhas e esposa estão mortas e que sua mãe ainda o domina mesmo depois de morta. É o labirinto das aparências sociais.

Ainda em relação à experienciação desse labirinto de repetições vivido por Éolo, podemos trazer a lume o conto popular "A menina enterrada viva":

Em cima da sepultura da órfã nasceu um capinzal bonito. O dono da casa mandou que o empregado fosse cortar o capim. O capineiro foi pela manhã e quando começou a cortar o capim, saiu uma voz do chão, cantando:

Capineiro de meu pai!

Não me cortes os cabelos...

Minha mãe me penteou,

Minha madrasta me enterrou,

Pelo figo da figueira

Que o passarinho picou... 
Chô! Passarinho!

O capineiro deu uma carreira, assombrado, e foi contar o que ouvira. O pai veio logo e ouviu as vozes cantando aquela cantiga tocante. Cavou a terra e encontrou uma laje. Por baixo estava vivinha, a menina. O pai chorando de alegria abraçou-a e levou-a para casa. (CASCUDO, 1986, p. 197-198)

Nesse conto, temos a repetição do arquétipo da madrasta má, que maltrata a enteada, fazendo-a fazer todas as atividades domésticas da casa, além renegá-la a um espaço específico da casa em que vive. Podemos fazer a leitura também da semelhança existente dessa narrativa com o conto "Cinderela", uma vez que neste temos a presença da madrasta que maltrata a enteada. A diferença consiste no fato de que no conto popular "A menina enterrada viva" a garota é morta pela madrasta. $\mathrm{O}$ fato de a menina ser morta é o que pode ter acontecido com as filhas de Cacilda e Éolo, porque conforme sinalizamos não fica explícito na narrativa se foi a mãe delas quem as matou ou se foi o retrato da sogra no quadro. Além disso, podemos observar que o conto de Rubião faz remissão direta ao aspecto do pai desenterrar a filha e ela ainda estar viva, tanto que em "Petúnia", as filhas saem dançando assim que o pai - Éolo - as desenterra.

Relevante ainda apontar que a temática abordada por Murilo Rubião em seu conto "Petúnia" é marcadamente amalgamada pelo gótico, conforme elucida David Roas (2006): d“interés estético por lo sobrenatural coincide (y no por casaulidad) com el desarrollo del gusto por lo horrendo y lo terrible, una nueva sensibilidade - lo sublime - que tomaba el horror como fuente de deleite e de beleza" (ROAS, 2006, p. 59). O sobrenatural que se instaura no conto de Rubião parte do cotidiano, de ações casuais, e acaba proporcionando um desconcerto das relações instauradas entre os personagens, assim como a subversão das mesmas. Com isso podemos afirmar que "na narrativa gótica aparecem figuras e elementos estereotipados que encarnam e evocam as angústias de uma cultura" (BOTTING apud CESERANI, 2006, p. 90). Logo, os estereótipos que Murilo Rubião traz em sua tessitura narrativa, como mãe/madrasta, sogra, homem, esposa, ao serem trabalhados em sua malha narrativa, ganham novos contornos, instigam novas maneiras de ver esses sujeitos e os contextos sociais e discursivos em que os mesmos foram instaurados. Por isso, emerge o sentimento da angústia, não somente porque a narrativa impulsiona o instável, o incongruente e sim também porque incita novas leituras de um mundo que está sendo pintado por Rubião.

\section{O sonho de Rubião, de Éolo e do leitor}

Rubião termina seu conto da seguinte maneira: "Não dorme. Sabe que os seus dias serão consumidos em desenterrar as filhas, retocar o quadro, arrancar as flores. Traz o rosto 
constantemente alagado pelo suor, o corpo dolorido, os olhos vermelhos, queimando. O sono é quase invencível, mas prossegue" (RUBIÃO, 2010, p. 189).

Estaria Éolo dormindo e consequentemente sonhando? Tolkien exclui as narrativas que usam do mecanismo do sonho quando se trata dos contos de fadas:

Em seguida, depois das histórias de viajantes, eu também excluiria, ou consideraria inadequada, qualquer história que use o mecanismo do Sonho, do sonho do sono humano real, para explicar a aparente ocorrência de suas maravilhas. Pelo menos, mesmo que sob outros pontos de vista o próprio sonho relatado fosse um conto de fadas, eu condenaria o todo como algo gravemente falho, tal como um bom quadro numa moldura deturpadora. (TOLKIEN, 2013, p. 13-14)

Se concordássemos com Tolkien teríamos que apagar da história dos contos de fadas narrativas como Alice no país das maravilhas, de Lewis Carroll, A terra dos meninos pelados de Graciliano Ramos e $O$ mágico de $\mathrm{Oz}$, de L. Frank Baum. Pensamos que o recurso do sonho pode ser potencializador de sentidos nas narrativas, sejam elas de fadas ou não. Em vista disso, acreditamos que Murilo Rubião utiliza-se, do mecanismo do sonho para nos fazer refletir: Será que Éolo não estaria sonhando desde o início? Será que tudo não passaria de um sonho e quando ele acordasse estaria em umas das festas entediantes de sua mãe? Rubião não nos deixa pistas do que aconteceria caso Éolo acordasse, mas deixa impresso na última página de seu conto a frase "O sono é quase invencível, mas prossegue". Um sono permeado por sonhos? Talvez. Éolo sonha, Rubião sonha, transgride, pinta o quadro de uma sociedade, subvertendo padrões. E, juntamente com Éolo e Murilo Rubião, também vamos sonhando, o sonho daqueles que não sabem se estão dormindo ou se estão acordados.

\section{Considerações finais}

No conto "Petúnia", de Murilo Rubião, conseguimos averiguar a sua maestria enquanto um dos expoentes da literatura fantástica do Brasil; por intermédio da análise, foi possível realizamos paralelos entre o conto rubiano, os mitos, os contos de fadas tradicionais, apontando como as temáticas são recorrentes e como as mesmas são absorvidas, adaptadas para o contexto de produção de uma determinada época. Ademais, vislumbramos que o modo como Rubião trabalha o seu enredo nos faz pensar a concepção de J.R.R. Tolkien acerca dos contos de fadas, uma vez que, assim como Tolkien, Murilo Rubião constrói a sua própria percepção do mundo real, mas, primordialmente, a sua imagem de como a magia/fantástico deve irromper no texto literário. 
Mágico, hiperbólico, exagerado, Murilo Rubião nos apresenta um conto que parte do mundo real, de circunstâncias prosaicas e acaba nos fazendo sonhar, sonhar com outros mundos, outros seres, com uma outra realidade em que os papeis sociais são subvertidos.

\section{Referências}

CAMUS, Albert. O mito de Sísifo. Rio de Janeiro: Record, 2010.

CANDIDO, Antonio. A nova narrativa. In: Paulo: Editora Ática, 1989. . A educação pela noite e outros ensaios. São

CASCUDO, Luis da Camara. Contos tradicionais do Brasil. Belo Horizonte: Editora Itatiaia Limitada, 1986.

CESERANI, Remo. O fantástico. Tradução de Nilton Cezar Tridapalli. Curitiba: Ed.UFPR, 2006.

COMMELIN, P. Nova mitologia grega e romana. Belo Horizonte: Editora Itatiaia Limitada, 1983.

CHAMBERS, Robert W. O rei de amarelo. Tradução de Edmundo Barreiros. Rio de Janeiro. Editora Intrínseca, 2014.

FOUCAULT, Michel. A arqueologia do saber. Tradução de Luiz F. Baeta Neves. 6. ed. Rio de Janeiro: Forense Universitária, 2000.

GAMA-KHALIL, Marisa Martins. Murilo Rubião nos arredores do mito e do real maravilhoso. Literartes, n. 6, p. 46-70, 2016.

RUBIÃO, Murilo. Obra completa. São Paulo: Companhia das Letras, 2010.

ROAS, David. El nacimiento de lo fantástico. In: . De la maravilla al horror. Los inicios de lo fantástico em la cultura española (1750-1860). Pontevedra: Mirabel, 2006, p. 59-69).

KRISTEVA, Julia. Introdução à semanálise. Tradução de Lúcia Helena França Ferrari. São Paulo: Perspectiva, 2005.

PERRAULT, GRIMM, ANDERSEN \& OUTROS. Contos de fadas. Apresentação de Ana Maria Machado; tradução Maria Luiza X. de A. Borges. Rio de Janeiro: Zahar, 2010.

POE, Edgar Allan. O retrato ovalado. In: . Histórias extraordinárias. Seleção, apresentação e tradução José Paulo Paes. São Paulo: Companhia das Letras, 2008.

TODOROV, Tzvetan. Introdução à literatura fantástica. São Paulo: Editora Perspectiva, 2008.

TOLKIEN, J.R.R. Árvore e folha. Tradução de Ronald Eduard Kyrmse. São Paulo: Editora WMF Martins Fontes, 2013. 


\section{Histórias de uma fila: “A fila” (1974), de Murilo Rubião, e o Brasil dos anos de chumbo Stories of a row: “A fila” (1974), by Murilo Rubião, and Brasil's years of lead}

Wilberth Salgueiro * Josiani Fernandes Rocha**

\begin{abstract}
RESUMO: Este trabalho empreende uma leitura do conto "A Fila", de Murilo Rubião, incluído no livro O Convidado, publicado em 1974. A burocracia parece o tema central da narrativa, mas a partir desse núcleo se podem vislumbrar aspectos fundamentais da história do Brasil autoritário de então, ainda que sob a capa de uma narrativa de cunho fantástico. A análise busca apoio em estudos murilianos de Davi Arrigucci Jr. e Jorge Schwartz, de Ricardo Piglia para a definição do duplo, bem como de teóricos do campo da História e da Sociologia, como Nadine Habert e Max Weber.
\end{abstract}

PALAVRAS-CHAVE: Murilo Rubião. Narrativa e ditadura. Ficção brasileira - anos 1970.

\begin{abstract}
This article undertakes a reading of Murilo Rubião's short story “A Fila," published in the 1974 book $O$ convidado. While bureaucracy seems to be the central motif of the narrative, one can glimpse at fundamental aspects in the history of authoritarian Brazil, albeit under the guise of a fantastic narrative. The analysis seeks support in studies of Rubião by Davi Arrigucci Jr. and Jorge Schwartz, Ricardo Piglia's definition of the double, as well as critics in the field of History and Sociology, such as Nadine Habert and Max Weber.
\end{abstract}

KEYWORDS: Murilo Rubião. Narrative and dictatorship. Brazilian fiction -1970s.

\section{Considerações iniciais}

Ao final de um ensaio publicado em 1987, Davi Arrigucci Jr. lança uma provocadora pergunta: "é possível falar dos contos fantásticos de Murilo Rubião sem se repetir? Parece que não" (ARRIGUCCI, 1987, p. 165). O que não nos parece possível é não renovar o debate em relação à obra do autor mineiro, pois trata-se, afinal, de um mundo que "não é e é" (p. 145) o nosso mundo ao mesmo tempo, mundo que se metamorfoseia a todo instante.

Os heróis dos contos de Murilo ainda existem por aqui. Hoje, transmudados de uma maneira que se possa apontá-los como desdobramentos dos heróis que antes foram, pois o mundo já não é aquele de 1947 (quando publicou seu primeiro livro, $O$ ex-mágico), embora em

\footnotetext{
* Doutor. Programa de Pós-Graduação em Letras da Universidade Federal do Espírito Santo (Ufes). Pesquisador do CNPq.

** Graduada em Letras-Português. Departamento de Línguas e Letras da Universidade Federal do Espírito Santo (Ufes).
} 
tantos aspectos permaneça bem parecido. Quantos ex-mágicos não devem estar neste momento pondo em prática a sua dose de suicídio lenta e diária em alguma sala rodeados de papéis, homens e falta de sentido? Quantos Caribas não são detidos diariamente sem nem mesmo saber o porquê, sem ao menos ter uma chance de defesa? Quantos Telecos e Alfredos, perdidos em suas próprias metamorfoses ora buscando se aproximar dos homens, ora buscando se afastar e proteger? São muitos os solitários e melancólicos personagens murilianos.

O conto "A fila" concentra várias questões que se reiteram na obra de nosso autor, como: (a) a burocracia, que é formulada como denúncia e pode ser vista de forma semelhante em "A Cidade", de 1947; (b) a repetição e a hipérbole, as quais Jorge Schwartz, em Murilo Rubião: a poética do uroboro (1981), caracterizou como os principais processos retóricos e formais da poética do autor; (c) a metamorfose, que se configura como um dos elementos típicos dos textos murilianos; (d) a tendência ao infinito, como na multiplicação dos fetos no conto “Aglaia”, de 1974, ou na construção sem limites de um arranha-céu em “O edifício", de 1965.

Publicada originalmente em 1974, a narrativa “A fila” elabora um estreito diálogo com a sociedade brasileira da época, jogando luz, em forma ficcional, em muitos aspectos sombrios de então. $\mathrm{O}$ conto traz o tema central da burocracia, também observado em outros contos do autor (como "A cidade" e "Botão-de-rosa"). Aqui, Murilo Rubião faz do tema um pano de fundo para denunciar também outras questões pertinentes à época, como a corrupção, a violação de direitos, o clientelismo, o patrimonialismo, o machismo e o racismo. Questões que ainda ecoam em um Brasil que já não é mais o de 1974, mas que ainda - sob tantos ângulos, já no século XXI - o é. A análise do conto contará com estudos de Ricardo Piglia (2004) a respeito do duplo, salientando as noções de narrativa aparente e narrativa cifrada, sob as quais vemos a questão da burocracia estender-se como a visível/aparente e outras questões como secretas/cifradas. Também lançaremos mão de textos de Davi Arrigucci Jr. e Jorge Schwartz, estudiosos da obra do autor de $O$ pirotécnico Zacarias, assim como de reflexões de Nadine Habert e Max Weber. 


\section{Primeiros passos: “Ao sobrevir-lhes de repente a angústia, eles buscarão a paz, e não haverá" (Ezequiel, VIII, 25) ${ }^{1}$}

Tratando-se de um escritor com tantas peculiaridades, cabe trazer algumas formulações a respeito do livro no qual se encontra o conto em foco.

Publicado pela editora Quíron, em 1974, e em 1978 pela Ática, O Convidado, terceiro - e último ${ }^{2}$ - livro totalmente inédito de Murilo Rubião, possui uma atmosfera temática que se coloca como o oposto daquela tratada em seus primeiros contos, atmosfera que Jorge Schwartz definiu como uma visão radicalizada do absurdo:

Assim, as policromias iniciais (arco-íris e outros signos conotativos da esperança) desaparecem totalmente na última coletânea de contos. Se as metamorfoses continuam, nunca mais, no entanto, surgem ternas figuras como Teleco. [...] o bestiário inicial deixa de existir, cedendo lugar ao homem despojado - agora, como antes, herói central -, sem fazer apelo à metáfora animal ou ao recurso da magia. Desnudado de máscaras, ele se confronta consigo mesmo e com o seu contexto. (SCHWARTZ, 1981, p. 93)

Entre essas duas obras, a estreia de Murilo e o lançamento de sua última coletânea de contos inéditos, está a elaboração do conto “O Convidado", que começou a ser escrito em 1945 e só veio a ser lançado na coletânea homônima de 1974, ou seja, um tempo de 26 anos para dar a público uma nova história (Humberto Werneck [1986] dizia que o mineiro "murilava" seus textos). O fato é que é difícil não relacionar a trajetória deste conto à trajetória angustiante do próprio protagonista, José Alferes, que é convidado para uma misteriosa festa à fantasia e, na preocupação de chegar até lá, entra por um caminho do qual não consegue jamais desvencilharse, nem achar o caminho de volta. A julgar pela epígrafe, que, neste caso, faz jus ao conto na ficção e na vida do próprio conto: "Vê, pois, que passam os meus breves anos, e eu caminho por uma vereda pela qual não voltarei” (RUBIÃO, 2010, p. 197).

Os fogos de artifício de um pirotécnico ou as cores esperançosas de um ex-mágico vão deixando de pertencer a esse caminho tanto mais se torna impossível a concretização da volta; os animais, metamorfoseados ou não, em constante aproximação ou afastamento dos homens elevam isto a um tão elevado nível de execução que restam, por fim, pois, apenas homens. No livro $O$ Convidado, cada vez que aparece uma flor é apenas para que se possa arrancar-lhe de

\footnotetext{
${ }^{1}$ Epígrafe que abre o livro $O$ Convidado.

${ }^{2}$ Dos nove livros publicados em vida, três deles seriam, de fato, de contos originais $(O$ ex-mágico, $A$ estrela Vermelha e $O$ Convidado), tratando-se os outros lançamentos de republicações; com destaque, entre estas, para o livro Os Dragões e outros contos, que possuía, dos vinte, quatro contos originais.
} 
onde quer que insista em nascer, ou fazer-lhe brotar direto da lama só para que possa sumir e novamente brotar, como uma ferida sem cura, e a tentativa de aproximação aos animais e à natureza só pode existir com felicidade em pensamento. Quando concretizada na realidade dos personagens, essa aproximação causa a destruição e o remorso.

É neste contexto que se encontra o conto "A Fila" (2010), cuja narrativa se desenvolve na cidade, palco da entrega dos homens às “máquinas infernais", lugar onde máquinas trituram homens, e também homens que controlam essas máquinas trituram outros homens. É o lugar de onde pensa-se ter fugido o mistério, no qual acontecem coisas que - teoricamente inexplicáveis - somos instados a aceitar ${ }^{3}$.

Uma fila incrível: "E eles te instruirão, te falarão, e do teu coração tirarão palavras" (Jó, VIII, 10) ${ }^{4}$

$\mathrm{O}$ conto trata de um homem vindo do interior em direção à cidade a fim de cumprir uma missão: falar com o gerente de uma Companhia. Este homem chama-se Pererico e a Damião - que é quem o recebe e ao qual Pererico atribui, inicialmente, as funções de porteiro - diz tratar-se de assunto sigiloso, de terceiros. É nesse momento que o nosso protagonista recebe a primeira ficha de outras tantas, cujas numerações cada vez mais elevadas o colocarão mais distante a cada vez do seu objetivo, contrariando, assim, a sua vontade de regressar depressa à sua terra.

As fichas que recebe correspondem ao seu lugar em uma fila aparentemente infinita, que se multiplica através das salas e corredores e escadas tomando também o pátio da Companhia. A fila aumenta à medida que aumenta o conto, bem como a desconfiança de Pererico em relação ao "negro elegante [...] e de maneiras delicadas" (RUBIÃO, 2010, p. 76), que ali o recebeu pela primeira vez, Damião, cuja oferta em ajudar vinha sempre acompanhada de um capricho.

Com o passar do tempo, a difícil situação financeira de Pererico se acentua e ele se vê sem condições de seguir a seu modo nesse percurso, é forçado a abandonar o hotel e passa a dormir nos bancos dos jardins públicos. Então conhece Galimene, uma prostituta que aparecia às tardes no pátio da fábrica, e com ela inicia um relacionamento a princípio áspero, mas depois,

${ }^{3}$ É o que disse Murilo Rubião em entrevista a Elizabeth Lowe (1979) quando da pergunta sobre a importância do contexto urbano para a literatura fantástica. Ver: LOWE, Elisabeth (1979).

${ }^{4}$ Epígrafe do conto “A Fila”. 
a muito custo, ameno, visto o seu caráter indispensável para sua permanência na cidade. É ela quem alimenta as suas necessidades físicas, fisiológicas e também psicológicas.

A trajetória de Pererico chega ao final quando ele toma conhecimento, através de Damião, da morte do gerente, tendo restado apenas ele como o único ao qual o Gerente deixou de atender.

A presença do fantástico aparece, aqui, materializada no absurdo da condição de Pererico, que se vê completamente impossibilitado de cumprir um objetivo aparentemente simples devido às complexidades advindas de um sistema cujo funcionamento se mostra igualmente absurdo.

A reiteração e a hipérbole, tidas como principais processos retóricos e formais utilizados por Murilo, como apontou Jorge Schwartz, aqui se efetivam na retomada contínua de um lugar na fila sem nunca avançar. Pelo contrário, Pererico vê-se cada dia mais distante de alcançar seu objetivo, ao passo que a dimensão hiperbólica é constatada na observação dessa fila aparentemente infinita, que toma conta das salas, corredores e do pátio da Companhia, o que, segundo Schwartz, é mimetizado pelo próprio ato narrativo: a fila cresce à medida que cresce o conto, e a volta indefinida do personagem a ela se assenta como a redundância formal do discurso. $\mathrm{O}$ que nos coloca frente a um dos temas mais frequentes da obra muriliana: a tendência ao infinito. A repetição desse processo esvazia seu sentido, pois não leva o personagem a lugar algum. Dessa maneira, o meio (a fila) transforma-se em seu próprio fim.

Não à toa, nos lembraremos agora da rebelião dos meios contra os fins citada por Sartre (1968) em seu ensaio sobre o que ele chamou de fantástico moderno. Como afirmou o filósofo francês em relação a $O$ Processo (1925) e a Aminadab (1942), também o herói de nosso conto percorre os corredores da Companhia ávido por concretizar o fim que o trouxera àquele meio. Também a exclusão da natureza como característica desse mundo descrito por Sartre se manifesta neste conto, onde sua aparição serve apenas para atormentar as lembranças de Pererico sobre sua terra, enquanto ele se debate em meio à asfixiante cidade, pela qual não demonstra nenhuma afeição:

- Por que não aproveita o sol da manhã para ir à praia? Hoje ela fica cheia de belas mulheres.

- Não faz sentido dentro dos meus objetivos.

- Você conhece o mar?

- Nunca vi um!

- É pena. - prosseguia, contando uma porção de histórias marítimas que conhecia bem, sendo filha de marinheiro, nascida nas docas.

Cansados do mar a conversa caía no jardim zoológico, incentivando Pererico a contar proezas de animais ferozes de um circo americano que vira anos atrás. 
Deles voltava aos cavalos, vacas, galinhas e cabritos, o rosto transfigurado por alegres reminiscências.

$[\ldots]$

- Agora que você não tem obrigação de ir à fábrica, por que não fica? Poderia conseguir emprego.

- Odeio esta cidade. (RUBIÃO, 2010, p. 86-88)

Nesse mundo invertido ao qual Sartre definiu pertencer o fantástico moderno, não há espaço para a natureza, os personagens não encontram mais do que corredores e escadas que não levam a nenhum lugar, números indicando posições que não dizem da posição exata que, por alguma lógica existente, deveria ocupar, letreiros que encimam portas e não dizem o que dali se consegue ler, levando-os, assim, a outras portas.

Aqui, uma mensagem para a qual supõe-se um remetente, um mensageiro e um destinatário - e que, a princípio, figura-se como o tema central da trama - não consegue chegar a seu fim. Pererico (mensageiro) tem um assunto a tratar (mensagem) com o gerente (destinatário) da Companhia, assunto de terceiros (remetente), mensagem de cujo conteúdo jamais saberemos - pois o personagem o mantém em sigilo até o fim da narrativa - e cujo fim jamais se efetiva - pois o gerente, a quem destinava-se a mensagem, morre.

Sartre fala de homens-utensílios, imersos em atividades fatigantes e ininteligíveis, sendo o homem nada mais do que um meio em si mesmo: "Procede sempre de modo que trates o humano em ti mesmo e na pessoa dos outros como um meio e nunca como um fim." (1968, p. 117). Daí os personagens de "A Fila" se relacionando sempre à beira da incapacidade de relacionar-se afetivamente. $\mathrm{O}$ desejo do/no outro está sempre ligado a algo material ou que falta. A ponte tenta erguer-se sempre como uma forma de vampirização do outro.

Este quadro mostra-se de forma cíclica: Pererico quer chegar ao gerente, porém, para isto, precisa passar por Damião que, por outro lado, tenta a todo custo saber de que trata assunto tão sigiloso, e que inferniza a vida do interiorano com vistas a alimentar o próprio ego e vaidade. Pererico, com o tempo, vê-se fracassando, e é nesse momento de desânimo que lhe aparece Galimene, quem renova suas forças e "virilidade", e que, em contrapartida, avista em Pererico possibilidades de uma vida diferente da que a profissão de prostituta lhe reservara.

Assim, fica evidente o modo como cada um caracteriza o outro como um meio para um fim que se encontra em sua vontade própria. Isto confirma o prognóstico da incapacidade de relacionamento afetivo entre as personagens, já apontada por Schwartz como uma característica que não se limitaria ao conto em questão, mas que se estende por toda a obra muriliana. 
Em "Do fantástico como máscara", ao fazer uma analogia com O Castelo (1926), em que o personagem K. não consegue nunca chegar ao lugar em questão, Jorge Schwartz (2001) afirmou tratar-se "A Fila" de uma evidente crítica à burocracia e à degradação do homem oprimido por tal sistema, relação apontada também em artigo citado de Davi Arrigucci Jr. É este o tema que delineia o que poderemos chamar aqui de estrutura aparente do conto. Trata-se de um relato visível que escamoteia, aos olhos ingênuos, um segundo enredo do qual irrompem questões outras que, neste caso, corroboram e ampliam tal visão. Ricardo Piglia diz, em "Teses sobre o conto", que "um conto sempre conta duas histórias", de modo que "um relato visível esconde um relato secreto, narrado de um modo elíptico e fragmentário" (PIGLIA, 2004, p. 88). $\mathrm{O}$ escritor argentino alude a autores como Hemingway, Poe, Kafka, Borges. Sobre "O grande rio dos dois corações", conto de Hemingway, assinala que parece a descrição trivial de uma peixaria de tanto que o autor cifrou a história 2, que seriam os efeitos da Guerra em Nick Adams.

A crítica a um sistema burocrático se performatiza de modo bastante evidente no conto de Rubião. O próprio título, "A Fila”, confirma a temática principal da narrativa. Filas podem ser comumente associadas a ambientes formais, que dispõem de algum tipo de organização hierárquica, divisão de trabalho e até mesmo impessoalidade - já que se caracteriza pela disposição sequencial de pessoas ou coisas -, traduzindo, assim, algumas das principais características da burocracia segundo Max Weber (2016). Nesse sentido, tais elementos remontam respectivamente à posição de Damião em relação ao secretário da Companhia e deste em relação ao Gerente, bem como às respectivas funções que ali desempenham e, por fim, à descrição rasa, quando não nula destes.

O encaminhamento de uma leitura que se pauta nos elementos apresentados acima, tratando da burocracia e seus desvios na sociedade, pode ser sustentada de forma satisfatória a julgar-se apenas pela figura de Damião e suas ações ao longo da narrativa, as quais desdobramse em elementos que vão pouco a pouco deixando entrever a grande máquina burocrática à qual verdadeiramente serve. A postura que assume enquanto funcionário da Companhia resume-se a obstruir o caminho que pode levar Pererico ao gerente da fábrica. Ao valer-se de sua condição superior em relação a Pererico, que dele depende, Damião, "podendo" e não "querendo" ajudálo, deixa à mostra uma faceta em que vaidade e capricho colocam-se em primeiro plano, evidenciando numa relação de interesses um jogo sujo e já tão conhecido de nossa sociedade chamado "troca de favores":

Começou por cumprimentá-lo discretamente. Depois vieram as frases convencionais, evoluindo para um elogio ao bom gosto do negro na escolha das gravatas e roupas. Damião sorria satisfeito, a aguardar um 
pronunciamento formal de Pererico sobre suas intenções, o que finalmente aconteceu:

- Bem sei que em mais de uma ocasião fui grosseiro com você. É que eu me enraivecia com a sua insistência em saber minúcias de um assunto sigiloso. Faço-lhe agora um apelo para que me consiga, sem condições e fora da fila, uma audiência com o gerente.

Sentia-se envergonhado pelo discurso enquanto o crioulo aproveitava a oportunidade para exibir falsa modéstia:

- Há um pouco de exagero na sua confiança com relação ao meu prestígio. Quem marca esse tipo de audiência é o secretário da Companhia. Vamos lá pedindo-lhe que o acompanhasse. (RUBIÃO, 2010, p. 82-83)

Damião manifesta, assim, muitos dos elementos apresentados como disfunções burocráticas por Robert K. Merton (2016), ao tratar do poder nesse tipo de organização: exibição de sinais de autoridade; apego exagerado a regras e regulamentos; conflito entre as regras formais e informais; abuso da posição hierárquica na decisão de processos; ritualismo.

A noção de duplo foi estudada também por Eliane Mury em sua tese Machado de Assis e Murilo Rubião: as múltiplas possibilidades do duplo (2001). A autora se dedica a quatro contos de Murilo Rubião, valendo-se da teoria de Ricardo Piglia, e afirma que a história visível (superficial) varia de conto para conto, enquanto a história enigmática (profunda) seria a da "visão do homem como verdadeiro absurdo, a impossibilidade de se aceitar o humano como normal" (p. 79-80), sendo este o traço constante que uniria as quatro narrativas escolhidas como corpus em seu trabalho. No caso deste conto de Murilo, o relato que se subjaz ao visível não se trata propriamente de um relato "escondido", "secreto". Sua existência apenas se relaciona com esta maneira "secreta" no sentido de evocar o teor político que pairava sobre o Brasil à época de sua publicação: 1974 .

Embora uma análise que recaia somente sob o aspecto da figura de Damião como um representante fiel das práticas "burocracistas" presentes na narrativa - expondo, dessa maneira, que a Companhia e seu (des)funcionamento desvelam o modelo de organização burocrática se mostre relevante, há dados que permitem avançar nesta análise para o contexto histórico mais amplo que a envolve.

A questão da burocracia aliada à data de publicação do conto (1974) já permitiria localizar um provável período histórico a que Murilo estivesse, talvez, aludindo. Somados estes dois elementos, recaímos em um quadro triste de nossa memória, que muitos hoje ainda teimam resgatar. Este quadro ganha força e presença na narrativa à medida que saltam aos olhos palavras duras como: "ficha de metal", “escada de ferro", "portões do edifício", "portão dos fundos", "portões da fábrica" e "grades" (esta última remontando aos portões, atestando, assim, a sua composição dura, de metal). 
$\mathrm{Na}$ esteira da história contada na superfície visível, em um trecho que certamente passaria ao largo dos olhos do leitor comum - afinal está situado já no fim da narrativa, com toda a trajetória de Pererico dada por finalizar -, encontramos um dado histórico que permitiria confirmar essa possível alusão:

- Cansados do mar a conversa caía no jardim zoológico, incentivando Pererico a contar proezas de animais ferozes de um circo americano que vira anos atrás. Deles voltava aos cavalos, vacas, galinhas e cabritos, o rosto transfigurado por alegres reminiscências. (RUBIÃO, 2010, p. 86, grifos nossos)

Ora, em tal trecho nos fala brevemente o narrador sobre este "circo americano" - mas não tão breve a ponto de esquecer-se da valentia dos animais dali -, como se fosse algo assim desimportante na narrativa. Deve ser lido com os olhos de quem não desconhece a grande influência que teve Machado de Assis sobre Murilo Rubião. Com efeito, a menção de um circo americano no Brasil remonta a uma tragédia ocorrida em Niterói em 1961, com mais de quinhentos mortos - fato amplamente referido em pesquisas na internet ${ }^{5}$. Data capaz de situar temporalmente na História o nosso protagonista, por se tratar de um espetáculo visto "anos atrás”, entre os tempos difíceis da ditadura militar.

O trecho acima traduziria, assim, uma tirada irônica, artifício de que tanto valia-se Machado em seus textos. Aqui, tanto quanto nos textos de Machado, esse artifício dá força à ideia de registro histórico por meio da literatura, à ideia de que o modo como se conta uma história é também História. É nos detalhes que Murilo Rubião deixa entrever o teor de censura da época aludida. É no detalhe sutil da aparente irrelevância da menção a esse episódio trágico que Murilo funda os principais temas que essa narrativa traz.

A década de 1970, no Brasil, foi marcada pelo governo da ditadura militar, que teve nesse período o seu momento de glória e ruína, respectivamente através do dito "milagre brasileiro" e da crise do petróleo. Nas palavras de Nadine Habert, em "A década de 70: Apogeu e crise da ditadura militar brasileira",

Quando a década de 70 começou, vivia-se no Brasil o período mais duro da ditadura militar implantada em 64. Eram os anos do governo do general Garrastazu Médici (1969-1974). A censura estava institucionalizada, a tortura aos presos políticos corria solta. (HABERT, 1992, p. 7)

\footnotetext{
${ }^{5}$ Ver, por exemplo: https://pt.wikipedia.org/wiki/Trag\%C3\%A9dia_do_Gran_Circus_Norte-Americano. Acesso em: 27 abr. 2016.
} 
Murilo Rubião não estabelece com exatidão o espaço onde se desenvolve essa narrativa, sabe-se apenas que é na cidade, lugar posto como oposição ao campo - e pelo qual Pererico não esconde seu desgosto. Essa oposição campo x cidade vai além do contraste mencionado pelo próprio Murilo em entrevista citada (sobre o fato de o campo estar menos propenso a uma escravização da sociedade de consumo). No campo, ademais, ocorreram - tal como na cidade - tensões, conflitos, batalhas, guerrilhas durante a ditadura:

O processo de capitalização no campo, com a mecanização da produção, o predomínio do trabalho assalariado e a concentração da propriedade da terra, foi acompanhado por violenta expropriação e expulsão de milhões de pequenos proprietários e trabalhadores rurais das terras e das fazendas e pelo intenso êxodo para as cidades. (HABERT, 1992, p. 17)

Esse quadro relativo ao campo, que o conto delineia, caracteriza também uma crítica à modernização, ao (desenfreado) progresso do Brasil, que tinha esse momento representado por termos como "Brasil Grande", "Boom" e "Gigante da América Latina".

Em relação ao espaço, ainda, o autor deixa explícito tratar-se de um bairro operário, no qual o corpo de Galimene "não rendia muito" (RUBIÃO, 2010, p. 82). A palavra "operário" aparece apenas uma única vez em toda a narrativa, enquanto a menção à "fábrica/Companhia" ocorre quatorze vezes. Isto chama atenção para a questão do movimento sindical no período a que nos referimos. Greves, lutas por melhorias salariais e condições de trabalho foram duramente combatidas pela repressão, ocasionando intervenção nos sindicatos, invasão das fábricas e prisão dos grevistas:

\footnotetext{
Nos primeiros anos da década de 70, o movimento sindical viveu o período de maior desmobilização desde 1964. Mais do que nunca o movimento operário estava desarticulado e os trabalhadores submetidos a um pesado controle nos locais de trabalho. A estrutura e a legislação sindicais funcionavam como verdadeiras camisas-de-força e praticamente todos os sindicatos estavam controlados por diretorias imobilistas e pelegas. (HABERT, 1992, p. 35)
}

Também o tempo em "A Fila" se mostra vinculado a esse contexto pós-64. A passagem do tempo, na narrativa, não obedece a uma linearidade propriamente dita, demonstrando certo destempero, inconstância. A arbitrariedade assumida pelo narrador ao pular de um para seis meses no relato da trajetória de Pererico pode remeter - a partir de uma perspectiva alegórica às arbitrariedades ocorridas durante o governo ditatorial: os atos institucionais, a censura, as torturas e assassinatos, as prisões e cassações, a violação de direitos humanos e democráticos. 
Há uma constante transição da voz narrativa. O narrador flutua entre onisciente e observador, sempre que lhe é conveniente assumir uma ou outra posição. Traço inerente do oportunismo, tão característico da atuação daqueles que ocupam alguma função no interior de uma hierarquia institucional. Assim, recaímos novamente na figura de Damião, desta vez alinhando suas ações não mais pela narrativa visível, somente, mas como parte da narrativa profunda.

O papel que desempenha como gestor da fila, no plano superficial da narrativa, desdobra-se em papel de gestor das relações de poder na história que é contada por baixo desta, aludindo ao autoritarismo da época. Nesse sentido, o tema da burocracia, bem como o próprio Damião como personagem, figuram como elementos que "têm dupla função e são empregados de maneira diferente em cada uma das duas histórias" (PIGLIA, 2004, p. 91). Na história que se constrói na superfície, Damião é um funcionário cujas ações permitem entrever os males e os podres provenientes do sistema burocrático; já na história "secreta", a burocracia se torna a protagonista, sendo o meio pelo qual se efetivou a manutenção de um (E)estado de exceção que durou vinte e cinco anos, e Damião a personificação desse poder autoritário que atuou na forma também de garantir a manutenção desse Estado.

\section{Considerações finais}

O peso que o aparato burocrático teve no governo iniciado em 1964 alcançou gradativamente níveis altíssimos durante os anos do regime militar. A criação de órgãos como o SNI (Sistema Nacional de Informações) sustentou a ação do governo autoritário, funcionando como uma verdadeira "ilha de poder", como explicita Sonale Oliveira em "A ditadura militar e o insulamento burocrático: o SNI, um estudo de caso" (2012). A corrupção desenfreada da época se deve, em partes, a essa administração pautada na manutenção do regime. Os casos que podiam provocar grande escândalo ou comprometer o pessoal da ala militar eram silenciados para que o governo não passasse uma visão negativa que fosse de encontro à que era exibida pelos meios de comunicação. O SNI alcançou uma autonomia tão elevada entre os governos Costa e Silva e Médici, na década de 1970, que é possível figurá-lo como exemplo máximo de disfunção burocrática. Com efeito, a criação de um Ministério da Desburocratização, chefiado por Hélio Beltrão em 1979, aconteceu no sentido de justamente reduzir o impacto do aparato burocrático na sociedade brasileira.

Investigando o nome "Damião", encontramos novamente uma possível referência a Machado de Assis. Damião é também o nome do personagem de um famoso conto de Machado, “O caso da vara" (1997), publicado originalmente em 1891, em que o autor trata também de 
temas bastante caros à sua época, valendo-se igualmente de fina ironia ao narrar os acontecimentos.

A aproximação dos dois personagens vai além da coincidência do nome: do grego Damianós, Damião quer dizer “domar”, “vencer”, “subjugar”. Ambos expressam uma relação de poder sobre outros personagens, no nível de uma relação hierárquica - característica própria da burocracia. Enquanto o Damião gestor da fila exerce poder sobre Pererico (e este por Galimene), o Damião do conto de Machado, fugido do seminário, exerce algum poder sobre Sinhá Rita, e esta, por sua vez, sobre João Carneiro, padrinho do menino, estando essas redes ligadas, portanto, por uma estreita relação de interesses. Ambos sustentam, ainda, uma pose disciplinada, dócil, até, tendo sempre em mira o alcance de seus objetivos na narrativa. Assim como Damião nega-se a ajudar Pererico a chegar ao gerente no conto de Murilo, o menino Damião no conto de Machado não intervém para ajudar a pequena Lucrécia, escrava de Sinhá Rita que Damião havia prometido apadrinhar.

É através da figura de Damião que se fundam os temas principais da narrativa, que remontam ao contexto vivido pelo Brasil no período pós-64. Clientelismo, patrimonialismo, violação de direitos, corrupção, machismo e racismo são temas caros à época de Murilo e caríssimos à nossa época. Quarenta anos depois e as mesmas questões rondam o cenário da política brasileira, da sociedade brasileira. Houve resistência e luta, sim, durante os vinte e cinco anos do regime; há resistência e luta hoje, sim. Não nos encontramos especificamente em um regime fechado e ditatorial de governo, claro, mas é possível observar marcas silenciosas dessa época arrastando-se cada vez menos lentamente em nossa direção. As administrações públicas continuam valendo-se da burocracia como aparato capaz de mobilizar uma ou outra questão a fim de garantir os interesses mais obscuros. Conhecer o passado é uma forma de seguir no presente de olhos abertos, e atentos, a fim de que não se repitam os mesmos erros.

\section{Referências}

ARRIGUCCI, Davi. Minas, assombros e anedotas (Os contos fantásticos de Murilo Rubião). In: __ Enigma e Comentário. São Paulo: Companhia das Letras, 1987. p. 141-165.

ASSIS, Machado de. O caso da vara. In: . Páginas Recolhidas. São Paulo: Globo, 1997. p. 3-10.

HABERT, Nadine. A década de 70: apogeu e crise da ditadura militar brasileira. São Paulo: Ática, 1992. 
LOWE, Elisabeth. A opção do fantástico. Revista Escrita, São Paulo, ano IV, n. 29, 1979.

MERTON, Robert K. Poder da burocracia nas organizações. Disponível em: $<$ www.moodle.fgv.br/cursos/motivacao organizacoes ocw/pag_modulo1/1 6 4.htm $>$ Acesso em: 05 jun. 2016.

MURY, Viviane. Machado de Assis e Murilo Rubião: as múltiplas possibilidades do duplo. 2001. 144 f. Tese (Doutorado em Letras Vernáculas) - Universidade Federal do Rio de Janeiro. Rio de Janeiro, 2001.

OLIVEIRA, Sonale Diane. A ditadura militar e o insulamento burocrático: o SNI, um estudo de caso. Em tempos de História, Brasília, n. 20, jan-jul. 2012.

PIGLIA, Ricardo. Teses sobre o conto. In: Formas breves. Tradução de José Marcos Mariani de Macedo. São Paulo: Companhia das Letras, 2004. p. 87-94.

RUBIÃO, Murilo. Murilo Rubião - Obra Completa. São Paulo: Companhia das Letras, 2010.

SARTRE, Jean Paul. Aminadab, ou do fantástico considerado como uma linguagem. In: Situações I. Tradução de Rui Mauro Gonçalves. Lisboa: Europa-américa, 1968. p. 108-126.

SCHWARTZ, Jorge. A poética do Uroboro. São Paulo: Ática, 1981.

WEBER, Max. O que é a burocracia. Brasília: CFA, s/d. Disponível em: <www.cfa.org.br/servicos/publicacoes/o-que-e-a-burocracia $>$. Acesso em: 29 maio 2016.

WERNECK, Humberto. No vigor dos 70. Isto é. Novembro, 1986. Disponível em: <www.murilorubiao.com.br/imprenssa.aspx?id=5> . Acesso em: 20 maio 2016. 


\title{
Armação de mundo possível e processos de composição de personagens insólitos em "O pirotécnico Zacarias", de Murilo Rubião Framing of a possible world and composition processes for uncommon characters in "O pirotécnico Zacarias" by Murilo Rubião
}

\author{
Flavio García* \\ Luciana Morais da Silva**
}

\begin{abstract}
RESUMO: Os processos de composição de personagens com matizes insólitos não respeitam a lógica racional e aristotélica expectável nos mundos referenciais de base a que o ficcionista tem acesso, senão que a arranham, fissuram, fraturam ou, mesmo, rompem, instaurando o incomum e inesperado ao tensionar crenças e percepções. Os mundos possíveis armados a partir de procedimentos arquiteturais que instauram o incomum e inesperado são mundos que fazem crescer suas sensações de uma só vez, impregnados pela essência de um relato que se dá pela construção do insólito, como observou Edgar Allan Poe acerca de um conto insólito e horrorífico de Hawthorne, "Twice-told tales". Nesse mesmo universo, o conto fantástico, conforme Julio Cortázar, leva o leitor a mergulhar nas margens de um mundo insólito e a vivenciá-lo em sua amplitude de sentidos. "O pirotécnico Zacarias", de Murilo Rubião, encena um mundo possível cuja personagem central configura-se, dubiamente, como um cadáver adiado, transitando entre estados de existência. A narrativa ilustra noções de níveis físico e metafísico transbordados pela aparente possibilidade de o morto manter-se vivo, experienciando sensações com seus coadjuvantes, em um mundo nada natural ou ordinário.
\end{abstract}

PALAVRAS-CHAVE: Murilo Rubião. O pirotécnico Zacarias. Mundos possíveis. Figuração de personagem. Insólito ficcional.

\begin{abstract}
The composition processes for characters of uncommon shades do not respect the rational, Aristotelian logic expected in the referential worlds to which the fictionist has access, they rather scratch, crack, fracture, or even break such logic, instituting the unusual and unexpected by increasing tension in beliefs and perceptions. The possible worlds framed through architectural procedures that establish the unusual and unexpected are worlds that grow their sensations in the reader at once, impregnated by the essence of an account based on a construction of the uncommon, as Edgar Allan Poe once noticed about an uncommon, horrifying tale by Hawthorne, "Twice-told tales." In this same universe, the fantastic tale, according to Julio Cortázar, takes the reader to dive in the margins of an uncommon world and to experience it in its amplitude of senses. "O pirotécnico Zacarias", by Murilo Rubião, enacts a possible world whose central character configures, dubiously, as a deferred corpse and a usual man, transiting between states of existence. The narrative illustrates notions of physical and metaphysical levels overflowed by the apparent possibility of the dead to remain alive, experiencing sensations with their supporting characters, in an world that is anything but natural or ordinary.
\end{abstract}

KEYWORDS: Murilo Rubião. O pirotécnico Zacarias. Possible worlds. Character figuration. Fictional uncommon.

\footnotetext{
* Professor Associado da UERJ, atuando na graduação no PPG Letras, Teoria da Literatura e Literatura Comparada. Doutorado em Literatura Comparada.

** Iniciou, em maio de 2018, Pós-Doutorado em Letras - Estudos de Literatura - na Universidade do Estado do Rio de Janeiro (UERJ). Doutora em Letras - Teoria da Literatura e Literatura Comparada - pela UERJ e Doutora em Letras - Literatura de Língua Portuguesa - pela Universidade de Coimbra, em regime de cotutela (2016).
} 
Quando, na literatura brasileira, fala-se de fantástico, no sentido lato, ou seja, refere-se ao gênero literário ou ao modo discursivo sem aprisionamento à perspectiva teórica defendida por Tzvetan Todorov $(1992)^{1}$, que se tornou um paradigma necessário para a crítica coetânea ou posterior a ele ${ }^{2}$, tem-se como inevitável e inequívoca a referência à obra de Murilo Rubião (1917-1991). É importante, contudo, ressaltar, logo de início, que, no caudaloso percurso da crítica ou da historiografia literárias produzidas em torno da diminuta obra do contista ${ }^{3}$, verificam-se diferentes conceituações que, de um modo geral, poder-se-iam facilmente inscrever sob a abrangente denominação de "insólito ficcional"4. Aliás, nesse sentido, Antonio Candido (1918-2017) já observara que, com a publicação do "livro de contos $O$ ex-mágico (1947), Murilo Rubião inaugurou no Brasil a ficção do insólito absurdo" (1987, p. 208). Para este crítico e historiador, a predominância do insólito na literatura brasileira, a partir da década de 1970, com José J. Veiga e Roberto Drummond, em que se verifica o “insólito no texto e no contexto [...] [,] teve nos contos do absurdo de Murilo Rubião seu precursor” (1987, p. 208).

Jorge Schwartz, em trabalho cujo recurso é imprescindível quando se pretende estudar o projeto de construção ficcional de Murilo Rubião, portanto, sua armação de mundos possíveis e, consequentemente, os processos de composição de personagens que emprega, ao comentar as estratégias empregadas por Rubião em "A lua", adverte que "este modo narrativo (invariante na poética do Autor) opõe-se à teoria do fantástico formulada por Tzvetan Todorov, onde a dúvida é assumida como condição sine qua non para definir o gênero narrativo em questão"

\footnotetext{
${ }^{1}$ Para Todorov, “A expressão 'literatura fantástica' refere-se a uma variedade da literatura ou, como se diz comumente, a um gênero literário" (1992, p. 7). Ele entende que "os gêneros existem a diferentes níveis de generalidade e que o conteúdo dessa noção se define pelo ponto de vista escolhido" (1992, p. 9), Assim, "Toda descrição de um texto, pelo próprio fato de ser com a ajuda das palavras, é uma descrição de gênero" (1992, p. 11). O crítico búlgaro adverte que os gêneros correspondem a um "sistema de categorias" que os fundamenta e do qual eles dependem para se constituírem (1992, p. 12), e "uma obra pode, por exemplo, manifestar mais de uma categoria, mais de um gênero" (1992, p. 26). Daí que seja bastante plausível desaprisionar-se da restritiva definição do fantástico por ele proposta (1992, p. 29-46) e admitir a ampla noção de modo sugerida por Filipe Furtado, aproximando-se de Rosemary Jackson (1981), ao defender que "o modo fantástico abrange [...] a maioria do imenso domínio literário e artístico que, longe de se pretender realista, recusa atribuir qualquer prioridade a uma representação rigorosamente 'mimética' do mundo objetivo" (2017). Para este estudioso, a concepção modal "Recobre [...] uma vasta área a muitos títulos coincidente com a esfera genológica usualmente designada em inglês por fantasy" (2017).

${ }^{2} \mathrm{Na}$ opinião de Furtado, “é com Introduction à la littérature fantastique de Tzvetan Todorov [, publicado em 1970,] que a crítica do género atinge de certo modo a mioridade" (1980, p. 14).

${ }^{3}$ Quantitativamente, a obra autorizada pelo autor é consideravelmente pequena, restrita a contos, dos quais, apenas 33 foram publicados. "O escritor mineiro deixou uma obra bastante singular, composta de 32 narrativas curtas já publicadas, uma ainda inédita e numerosos tetos em fase de produção - rabiscados, rascunhados, inacabados” (GARCÍA, 2013, p. 11).

${ }^{4}$ A propósito, veja-se GARCÍA, 2012.
} 
$(1987 \text {, p. } 67-68 \text { - grifo do autor })^{5}$. Assim, torna-se nítido que Schwartz opta por vincular o fantástico rubiano à concepção modal, não à genológica como Todorov a circunscreve.

Procurando delimitar "o universo fantástico" (SCHWARTZ, 1987, p. 54-82) sob a perspectiva da linguagem, Schwartz destaca a transgressão, a partir da "norma extra-textual definida pela tradição cultural" (1987, p. 54), como procedimento básico dessa vertente ficcional. Para sustentar sua hipótese, ele elenca três categorias constitutivas. Primeiramente, “o sólito, que sói acontecer, e que representa a vigência da norma" (1987, p. 54 - grifo do autor). A seguir, "o insólito, que não sói acontecer, opondo-se assim à norma, apontando para o estranho" (1987, p. 54 - grifo do autor). Por fim, “o sobrenatural propriamente dito, que não tem possibilidade alguma de acontecer no universo real, apontando na ficção para o 'fantástico' e o "maravilhoso"” (1987, p. 54 - grifo do autor).

É muito clara a correlação que Schwartz estabelece entre o mundo possível armado pelo ficcionista e o mundo referencial de base a que este recorre para ordenar sua proposta de compreensão da poética rubiana no nível da linguagem. Dessa forma, pode-se entender que ele considere que Rubião se "recusa [a] atribuir qualquer prioridade a uma representação rigorosamente 'mimética' do mundo objetivo" (FURTADO, 2017). Logo, justifica-se sua escolha por aproximar a obra do escritor mineiro não ao fantástico genológico, como circunscrito por Todorov (1992), mas ao fantástico modal, ainda que, em sua argumentação, não chegue a tratar do fantasy, distante, ainda, do escopo conceitual atribuído por Furtado ao modo fantástico.

Admitindo-se como possível esse percurso crítico e historiográfico que se vem, desde há muito, desenvolvendo sobre a obra de Murilo Rubião, chega-se, com bastante conforto metodológico, à fundamentação necessária à verificação de como o escritor arma seus mundos possíveis e a que processos de composição de personagens recorre a fim de instaurar cenários insólitos. Pode-se, ainda, para melhor instrumentalizar a leitura de "O pirotécnico Zacarias", objeto de leitura aqui proposto, valer-se da embrionária sistematização dos "elementos da

\footnotetext{
${ }^{5} \mathrm{Na}$ visão de Todorov, no fantástico, “A ambiguidade se mantém até o fím da narrativa” (1992, p. 30). Ele postula a premissa de que "CCheguei quase a acreditar' [...] [seja] a fórmula que resume o espírito do fantástico" (1992, p. 36), Para ele, “A hesitação do leitor é [...] a primeira condição do fantástico. Mas será necessário que o leitor se identifique com uma personagem particular" (1992, p. 37). E advoga que "o fantástico é um caso particular da categoria mais geral da "visão ambígua"” (1992, p. 39). Enfim, em sua ótica, “O fantástico [...] dura apenas o tempo de uma hesitação: hesitação comum ao leitor e à personagem, que devem decidir se o que percebem depende ou não da 'realidade', tal qual existe na opinião comum" (1992, p. 47-48). Logo, caso dissipada a dúvida, a narrativa encaminha-se ou para o maravilhoso, se sua natureza insólita é aceita e admitida, ou para o estanho, caso esta seja explicada racional e logicamente. O fantástico é, na visão desse crítico búlgaro, um gênero sempre evanescente, cuja natureza encontra-se ameaçada por seus domínios contíguos.
} 
discursivização" apresentada pelo semiótico boliviano Renato Prada Oropeza, distribuídos em “temporalização", "espacialização", “actorialização" e "níveis de relação 'pragmática”" (2006, p. 58-60).

Prada Oropeza considera a manifestação do insólito como sendo o elemento central e característico da configuração semiótica do fantástico (2006, p. 56), pois, segundo ele, se há um gênero que, em sua estruturação semionarrativa, propõe o insólito como seu elemento central e característico, este gênero é o fantástico (2006, p. 56). Para ele, os discursos fantásticos elaborados a partir da segunda década do Século XX apresentam, como marca própria e distintiva, o insólito, emergindo em um clima de aparente normalidade (2006, p. 57). Essa emersão se daria pela composição incongruente, em relação à lógica racional e aristotélica, de qualquer das categorias básicas da narrativa - personagens (actorialização), espaço (espacialização) e tempo (temporalização) -, isoladamente ou não, ou, ainda, por procedimentos discursivos que inter-relacionam o objeto texto e os sujeitos autor e leitor (níveis de relação pragmática), em correlações com o mundo acessível, tomado por base referencial pelo ficcionista.

A obra de Rubião, produzida basicamente entre o segundo e o terceiro quartel do Século $\mathrm{XX}^{6}$, encontra-se consoante com os "novos discursos fantásticos" como pensados por Prada Oropeza (2006). Nesse enquadramento sugerido pelo semiólogo boliviano, entrariam aquelas narrativas cujo elemento central e caracterizador fosse o insólito, a despeito de haver ou não a tal hesitação apontada por Todorov como essencial ao gênero. As narrativas de Rubião representariam, dessa maneira, aquele outro e novo fantástico prenunciado por Todorov ao aludir à obra de Franz Kafka, em que "o acontecimento sobrenatural não provoca mais hesitação pois o mundo descrito é inteiramente bizarro, tão anormal quanto o próprio acontecimento a que serve de fundo" (TODOROV, 1992, p. 181). Aliás, "já [...] em 1947, data da publicação de [...] O ex-mágico [...], o crítico Álvaro Lins estabelecia uma proximidade entre o estilo de Rubião e o do escritor tcheco Franz Kafka”(ANDRADE, 1999, p. 275).

\footnotetext{
${ }^{6}$ Faz-se mister destacar que, no geral, a obra conhecida de Murilo Rubião foi originalmente produzida entre as décadas de 1940 e 1970, não havendo perfeita isonomia entre o momento da escrita e o da publicação. Fora isso, ao longo dos tempos, muitos de seus textos foram republicados sem alterações ou com modificações desde as mais pontuais até algumas demasiado radicais. Como observou Vera Lúcia Andrade:
}

Murilo tinha uma maneira muito peculiar de escrever. Além de reelaborar, constantemente, a linguagem de seus contos, ele costumava refazê-los sempre, mesmo após terem sido publicados. Além de modificar parágrafos inteiros, ele alterava o final de suas histórias e até mesmo o título dos textos, como ocorreu com o conto "Bruma", publicado originalmente sob o título de "A estrela vermelha". (1999, p. 274) 
Os "elementos de discursivização" de que fala Prada Oropeza ao tratar dos procedimentos que levam à instauração do insólito, traço característico e distintivo dos "novos discursos fantásticos", correspondem, efetivamente, às categorias básicas da narrativa personagem, espaço e tempo - e à efabulação - processo narrativo que envolve as inter-relações do objeto texto com os sujeitos autor e leitor, implicando a própria enunciação em si. A instauração do insólito nesses elementos se daria, segundo ele, pela manifestação de traços incoerentes na sua composição, tendo em vista a lógica racional e aristotélica que o sistema semionarrativo realista toma por referência de base para sua elaboração. Sempre que, na composição de qualquer desses elementos discursivos, arranha-se, fissura-se, fratura-se ou rompe-se aquela lógica esperável, tem-se, por produto discursivo, o insólito.

Via de regra, ainda que a tal não aluda, Prada Oropeza está, de fato, com essa sua proposta de abordagem do texto, tangenciando a teoria dos mundos possíveis, que são armados intensionalmente, no plano do discurso, com imagens representativas dos referentes extensionalmente acessados nos mundos de base a que o autor do texto recorre, pois,

a intensão textual é resultado da configuração linguística da extensão textual [...]. O referente ou conjunto referencial é parte da realidade exterior ao texto. [...] os elementos correspondentes ao conteúdo do texto estão contidos em um nível cotextual que é semântico-intensional, (ALBALADEJO MAYORDOMO, 1998, p. 45 - tradução nossa)

Esses mundos de base correspondem aos mundos objetivos de vivência experienciável pelos seres humanos em seu quotidiano regular, sendo os mundos de cada indivíduo, isoladamente, ou dos coletivos, comunitariamente. De um modo geral, estes mundos se nutrem da noção de real de cada tempo histórico, transmutando-se diacronicamente conforme as modificações naturais por que toda sociedade perpassa, variando ao longo cronotopicamente, já que, "Como objeto linguístico, o texto literário possui uma estrutura profunda que é comunicável graças ao significante textual; dita estrutura profunda do texto literário responde ao referente que é parte da realidade que dito texto expressa" (ALBALADEJO MAYORDOMO, 1998, p. 45 - tradução nossa).

Os mundos possíveis textuais se constituem pelos seres, estados, processos e ações buscados referencialmente nos mundos objetivos de base que o autor acessa. Esses elementos vêm ao texto balizados por valores lógicos de existência e não existência dos seres, e de verdades e falsidade dos estados, processos e ações. Os valores semânticos desse balizamento estão subordinados a um conjunto de regras que reproduzem a capacidade do receptor do texto 
de decodificar as informações nele contidas (ALBALADEJO MAYORDOMO, 1998, p. 52). Por isso, todo "texto [...] manifesta e contém um complexo de mundos que está situado no espaço extensional relativo a ele mesmo (ALBALADEJO MAYORDOMO, 1998, p. 56 tradução nossa).

O complexo de mundos que constitui o mundo possível de um texto equivale a conjuntos de submundos macroestruturalmente organizados, formando espaços intersecionais ou não. Os mundos possíveis textuais são, portanto, emaranhados de seções de mundo, de partes de mundo, “com a correspondente indicação de valor lógico" (ALBALADEJO MAYORDOMO, 1998, p. 56 - tradução nossa). Daí que "A estrutura de conjunto referencial que o texto expressa seja um mundo parcial ou parcela de mundo, que se comunica linguisticamente" (ALBALADEJO MAYORDOMO, 1998, p. 69 - tradução nossa).

As seções ou parcelas de mundo, submundos que arquiteturalmente se articulam para garantir a unidade do mundo possível textual, estão intimamente coligadas aos indivíduos que participam desse complexo de mundos do texto. "Na estrutura referencial de um texto [...] há um submundo de cada pessoa; [e,] se se trata de um texto literário[,] para cada uma das personagens se constitui um submundo" (ALBALADEJO MAYORDOMO, 1998, p. 70 tradução nossa). A vinculação de cada um dos submundos de um texto ao sistema narrativo realista ou ao não realista depende do valor semântico dos seres, estados, processos e ações semiotizados (ALBALADEJO MAYORDOMO, 1998, p. 70-74)7.

Logo, focalizando mais detidamente a literatura, seara em que inscreve a obra de Murilo Rubião, tem-se que "O texto narrativo é a conjugação e o suporte do mundo ficcional criado pela fantasia do autor e o elemento de projeção estético-comunicativa de dito mundo"

\footnotetext{
${ }^{7}$ As tendências majoritárias da teoria e da crítica tendem, no geral, a distinguir entre ficção mimética e ficção não mimética, alocando o fantástico nesta última partição. Todavia, como bem deixa entrever Filipe Furtado, não se trata de a ficção fantástica ser ou não mimética, mas de recursar-se a "atribuir [...] qualquer prioridade a uma representação rigorosamente "mimética' do mundo objetivo" (2017).

Sem verossimilhança não há como qualquer narrativa ser minimamente compreensível e decodificável, e:

a verossimilhança é uma qualidade inerente à mímeses, de tal forma que toda construção mimética é verossímil, ao menos em sua relação com a realidade, mas não é exclusiva a ela, pois o verossímil não sendo somente semelhante ao verdadeiro, senão que tem aparência de ser verdade, podendo haver verossimilhança nas construções ficcionais não miméticas, como é o caso da literatura de ficção científica e da literatura gótica ou de terror, em que a construção dessa aparência de verdade é imprescindível para que o leitor perceba exatamente o efeito que o autor pretende conseguir (RODRÍGEZ PEQUEÑO, 2008, p. 126-127)
}

Todorov já havia sinalizado que "não é possível definir o fantástico como oposto à reprodução fiel da realidade" (1992, p. 42). Para ele, "No interior do gênero fantástico, é verossímil a ocorrência de reações "fantásticas"” (1992, p. 52). 
(ALBALADEJO MAYORDOMO, 1992, p. 66 - tradução nossa). O mundo - ou os mundos possíveis - semiotizado no texto narrativo ficcional emana (d)o imaginário de seu produtor, implicando uma intensão imagética interna, em relações de extensionalidade referencial externa. Sua compleição semântica dependerá do que o autor pretenda com seu texto, sempre subordinado aos contornos sócio, histórico e cultural que o envolvem, seja no ato de produção, seja nos diferentes atos de leitura. Dessa forma, "O mundo do texto ficcional é, portanto, um mundo que, mesmo mantendo conexão com o mundo real efetivo, é independente deste enquanto está sustentado pelo texto em que é intensionalizado" (ALBALADEJO MAYORDOMO, 1992, p. 67 - tradução nossa).

A partir dessas observações mais gerais, que tratam dos textos narrativos, ficcionais ou não, achegando-se mais especificamente ao texto literário, há que se considerar, com maior atenção e cuidado, a intensionalidade do autor, que pode tanto pretender a armação de um mundo de matiz realista, quanto a de um mundo não realista. Esse aspecto deve condicionar a leitura do texto, sendo necessária "a distinção entre o modelo de mundo real e o modelo de mundo fantástico, separados pela transgressão" (RODRÍGEZ PEQUEÑO, 2008, p. 128 tradução nossa). Tal transgressão seria resultado das fissuras, ranhuras, fraturas, rupturas no plano semântico da lógica racional e aristotélica, instaurando incoerências na composição de qualquer das categorias básicas da narrativa ou no seu processo efabulativo.

Para refletir sobre a obra de Murilo Rubião, é valiosa a metodologia operativa da teoria dos mundos possíveis, oferecendo, com nitidez, a separação entre literatura realista e literatura fantástica (RODRÍGEZ PEQUEÑO, 2008, p. 128), a partir das discussões acerca da verossimilhança, da mímeses e da ordenação de tipos de modelo de mundo referencial de base. Não se pode fugir ao fato de que "o fantástico é uma seção da ficção determinada pela infração, pela ruptura, pela transgressão" (RODRÍGEZ PEQUEÑO, 2008, p. 129 - tradução nossa). E o que se percebe, genericamente, nas narrativas de Rubião, é “o tipo de literatura que manifesta uma quebra da coerência do universo, quebra produzida pela irrupção insólita do extranatural no mundo quotidiano" (RODRÍGEZ PEQUEÑO, 2008, p. 131 - tradução nossa).

Nem todos os trinta e três contos de Murilo Rubião conhecidos pelo público em geral ${ }^{8}$ podem, sem reparos, ser inscritos no fantástico genológico ou modal, havendo aqueles que

\footnotetext{
${ }^{8}$ Esses trinta e três contos envolvem apenas aqueles que o autor considerou "prontos para publicação". Há, no entanto, outros que estão em seu espólio. Desses, “As unhas", datado de 1950, encontra-se publicado à parte pelo Suplemento Literário de Minas Gerais em novembro de 1994, durante as comemorações de três anos de morte do escritor. Em 2013, em livro rememorativo de seus vinte anos de morte, publicou-se um ensaio sobre este conto (GARCÍA, 2013) e, ao final do exemplar, uma versão baseada naquela antes divulgada pelo Suplemento Literário (RUBIÃO, 2013).
} 
transbordam qualquer das delimitações que se possam aplicar a essa heterogênea vertente literária. Mas o autor é, a despeito disso, apontado como a mais expressível figura representativa do fantástico literário brasileiro. Talvez porque "Para que uma obra seja fantástica não é necessário que [...] apresente todo um mundo fantástico conformado, com todos os seus elementos; não é necessário tampouco que todos os elementos dessa obra pertençam ao modelo de mundo fantástico" (RODRÍGEZ PEQUEÑO, 2008, p. 136 - tradução nossa). Ainda que o fantástico, em sua plenitude, não se encontre reconhecível em todas narrativas de Rubião, “A presença de um elemento estranho, maravilhoso, sobrenatural adscreve [sua] obra ao gênero" (RODRÍGEZ PEQUEÑO, 2008, p. 136 - tradução nossa), já que "a natureza fantástica de uma obra lhe é conferida pela inclusão em sua macroestrutura de alguns elementos da estrutura de conjunto referencial que supõem uma ruptura das regras do mundo real objetivo" (RODRÍGEZ PEQUEÑO, 2008, p. 137 - tradução nossa), e tal se dá na contística rubiana.

Enfim,

\begin{abstract}
o que marca o pertencimento ou não de um texto ao gênero fantástico é a relação de sua estrutura de conjunto referencial com a realidade empírica, mais exatamente se os seres, objetos, ações, estados, processos, ideias... daquela transgridem as leis do mundo real objetivo, porque, inclusive no caso, admissível, de que a irresolúvel falta de nexos entre distintos elementos do real seja a base do fantástico, no sentido de que sem essa zona de indeterminação nunca apareceria o fantástico na mente do leitor, o que faz este leitor, para considerar essa obra fantástica, é incorporar à primitiva estrutura de conjunto referencial seres, objetos, ideias, processos, ações... que a completam, de tal modo que, assim, na nova e mais ampla estrutura de conjunto referencial, exista algum elemento que transgride as leis do mundo real. (RODRÍGEZ PEQUEÑO, 2008, p. 138 - tradução nossa)
\end{abstract}

A armação de mundos possíveis pode ocorrer pela encenação da ficcionalidade, permitida por um contrato de ficção (REIS; LOPES, 2011, p. 160), tratado por Umberto Eco como "pacto ficcional", em que "a obra de ficção nos encerra nas fronteiras de seu mundo e, de uma forma ou de outra, nos faz levá-la a sério" (1994, p. 84). Desse modo, o que é narrado tende a parecer, por meio da verossimilhança, ter realmente acontecido. Nas palavras de Carlos Reis e Ana Cristina M. Lopes, "o fator primeiro da ficcionalidade é a colocação ilocutória do autor e o seu intuito de construir um texto na base de uma atitude de fingimento" (2011, p. 160 - grifo do autor).

Nos mundos possíveis ficcionais, construídos pela encenação da ficcionalidade no âmbito narrativo, tem-se a composição de múltiplos traços de configuração, desde dispositivos elaborados para experienciar no texto a vivência quotidiana, promovendo uma tentativa de transposição do mundo possível, dos seres de carne e osso, até a formulação de estratégias 
discursivas desencadeadoras da ruptura com a expectativa derivada da experiência em relação ao mundo dos seres de carne e osso.

As rupturas desencadeadas nos mundos possíveis ficcionais podem ser denominadas insólitas, inusitadas, surpreendentes porque geram uma subvertem na sequenciação efabulativa esperada. O insólito pode, portanto, ser produto de "um desdobramento do real ou sua multiplicação em formas que o negam como tal, na lógica do ilógico" (JOSEF, 2006, p. 202). De acordo com Lenira Marques Covizzi, o insólito pode ser caracterizado genericamente "como [...] um fenômeno de inadequação essencial entre as partes de um mesmo objeto, entre origem e fim, constituição e fim, utilidade e fim, ou sua especial significação e o contexto em que se insere" (1978, p. 26). Mas, para Prada Oropeza, o insólito seria, exatamente, o "incoerente" que surge, irrompe, em meio ao universo racional das coisas (2006, p. 58), produzindo certo desequilíbrio na narrativa.

Na construção desse universo de significações múltiplas, em que as certezas podem-se evadir, alguns "efeitos de índole fantástica, lúdica ou bizarra" (REIS, 2006, p. 18) seriam empregados a partir de processos instrucionais contidos em determinadas estratégias narrativas com a finalidade de garantir o efeito da suspeição. Assim, nos mundos possíveis do insólito ficcional, os seres - figuras - figurariam como eixos centrais da constituição de um mundo que, em geral, se autoquestiona.

A incerteza presente em narrativas do insólito ficcional "não afeta apenas a personagem, mas também, e principalmente, o leitor, ou, mais exatamente, o narratário" (RODRÍGUEZ PEQUEÑO, 2008, p. 133 - tradução nossa). Tais narrativas são formuladas por uma estrutura de conjunto referencial de elementos fantásticos, mas verossímeis (RODRÍGUEZ PEQUEÑO, 2008, p. 114), que estabelecem uma reafirmação do contrato ficcional. Para Reis, o insólito merece ser estudado em função dos processos de figuração que ele motiva (2014, p. 58), levando, com isso, a percepção acerca dos modelos e estratégias passíveis de serem usados na concepção de uma personagem figurada por traços do insólito.

Como adverte Reis, consonante ao que assinalam Albalejo Mayordomo e Rodríguez Pequeño, bem como outros teóricos dos mundos possíveis, em atitude pós-estruturalista, ultrapassadas as fases mais convencionais da narratologia e assumindo as tendências mais contemporâneas dos estudos narrativos, nos "universos ficcionais, as personagens ocupam lugar de destaque" (2006, p. 17), correspondendo àquela "categoria sem a qual não há relato que se sustente" (REIS, 2014, p. 49-50). Esse posicionamento se justifica uma vez que "cada um dos mundos de indivíduo (submundos) da estrutura de conjunto referencial é suscetível de ser dividido em submundos de acordo com as diferentes atitudes de experiência de ditos 
indivíduos em conexão com a temporalidade" (ALBALADEJO MAYORDOMO, 1998, p. 71 - tradução nossa) e com a espacialidade também. Logo, a macroestrutura de um mundo possível textual comporta tantos submundos quantas sejam as personagens que nele atuem, subdividindo-se, em múltiplos submundos de diversos submundos de cada personagem. Daí que a personagem - figura - seja vista com a categoria narrativa que determina os processos de armação dos mundos possíveis textuais, e, "se se trata de um texto literário, para cada uma das personagens se constitui um submundo" (ALBALADEJO MAYORDOMO, 1998, p. 70 tradução nossa).

Enfim, “em cada submundo do texto, ou seja, em cada submundo de indivíduo, há, por sua vez, vários submundos, que se estabelecem por meio das atitudes de experiência" (ALBALADEJO MAYORDOMO, 1998, p. 71 - tradução nossa) de suas personagens. "Essas atitudes de experiência podem ser de diversas classes: conhecimento, fingimento, desejo, temor etc.” (ALBALADEJO MAYORDOMO, 1998, p. 71-72 - tradução nossa). É por isso que a figuração ${ }^{9}$ das personagens, implicada em seus papéis na narrativa, acaba por ser o fator determinante na armação constelar do mundo possível ficcional, e as personagens ocupam, em razão disso, função essencial e predominante no processo efabulativo. Conforme Reis,

Sendo um processo ou um conjunto de processos, a figuração é dinâmica, gradual e complexa. Isto significa três coisas: que normalmente ela não se esgota num lugar específico do texto; que ela se vai elaborando e completando ao longo da narrativa; e que, por aquela sua natureza dinâmica, a figuração não se restringe a uma descrição, no sentido técnico e narratológico do termo, nem mesmo a uma característica, embora esta possa ser entendida como seu componente importante. $\mathrm{O}$ que [...] leva a realçar o seguinte: a figuração não é simplesmente um outro modo de entender a convencional caracterização, sendo antes um processo mais amplo, englobante e consequente. (2014, p. 53 - grifo nosso)

Não só as descrições física e psicológica interferem na figuração, mas, também, o nome, a alcunha, os predicativos, pois, como comenta Reis, tudo isso "funciona como dispositivo discursivo de figuração, às vezes com sugestão comportamental” (2014, p. 60). As ações que as personagens exercem ou sofrem, os espaços e dos tempos da história em que transitam, bem como suas crenças, vontades, seus sonhos, desejos, afetos, ódios, medos contribuem para a

\footnotetext{
${ }^{9}$ O termo "figuração" tem sido empregado e difundido, amplamente, por Carlos Reis e, segundo ele, "o conceito de figuração designa um processo ou conjunto de processos constitutivos de entidades ficcionais, de natureza e de feição antropomórfica, conduzindo à individualização de personagens em universos específicos, com os quais essas personagens interagem" (2014, p. 52 - grifo nosso).
} 
figuração. Portanto, são os processos de figuração das personagens que determinam os procedimentos da efabulação narrativa, sempre subordinada à lógica íntima das personagens (REIS, 2014, p. 49 - grifo do autor). Resumidamente, os processos compositivos da personagem envolvem, em linhas gerais:

a nomeação e ações da personagem, a sua relação com o espaço e o tempo, a forma e a frequência de esta gerir os seus diálogos e monólogos, bem como níveis e tiques de linguagem usados constituem procedimentos que, de forma implícita, caracterizam a personagem. (VIEIRA, 2014, p. 126)

No texto ficcional, em que o mundo possível armado se constitui como imaginário estruturado pelo autor para comunicar sua intenção, "a figuração, no que toca sobretudo aos dispositivos retórico-discursivos, requer atos de semiotização, ou seja, solicita a articulação de um discurso que produz sentidos e que gera comunicação, com efeitos pragmáticos" (REIS, 2014, p. 56 - grifo nosso). O universo textual é produto das relações extensionais com os referentes que fornecem elementos para a imagem vislumbrada pelo ficcionista.

É com base nesse legado que, por exemplo, as pausas descritivas, para caracterização alargada em regime omnisciente, são operadores discursivos da figuração, às vezes construindo retratos de personagem com apreciável potencial mimético (no sentido de Phelan, 1989:2). O mesmo afirmamos acerca dos movimentos temporais que reiteram traços físicos, culturais e temperamentais, como se vê na chamada personagem-tipo, dotada de acentuada feição temática e social (cf. Phelan, 1989:2-3), como se observa sobretudo na ficção realista do século XIX. (REIS, 2014, p. 56 - grifo nosso).

Como destaca Jens Eder, “as personagens nem são signos 'no texto' nem representações mentais subjetivas 'na cabeça' mas construtos intersubjetivos" (2014, p. 74 - tradução nossa), portanto, fruto da subjetividade criativa e receptiva. Sob essa perspectiva, Reis observa que a personagem bem caracterizada e inserida numa hierarquia estruturada, revela, em certo sentido, coerência e previsibilidade, com "pouca margem para o inusitado. A não ser, é claro, que esse inusitado esteja desde logo inscrito (e, portanto, previsto) no código genético da figura em desenvolvimento" (2015, p. 80).

No caso do conto de Murilo Rubião, "O pirotécnico Zacarias", em que a figura central aparece referida no título, com sua nomeação - Zacarias - e um predicativo que lhe atribui certo mister laboral - pirotécnico -, é inconteste que: 
a figuração não se restringe a uma descrição, no sentido técnico e narratológico do termo, nem mesmo a uma caracterização, embora esta possa ser entendida como seu componente importante [...] a figuração não é simplesmente um outro modo de entender a convencional caracterização, sendo antes um processo mais amplo, englobante e consequente. (REIS, 2014, p. 53)

Um pirotécnico é alguém que "trabalha em fogos-de-artifício ou de guerra" ( $<$ https://www.priberam.pt/dlpo/pirotécnico $>$, acessado em 3 set. 2017). Zacarias significa "lembrado por Deus", nomeando "vários personagens bíblicos, destacando-se entre eles o que é mencionado no Antigo Testamento como um dos doze profetas, autor do livro 'Zacarias', e o pai de João Batista, que ficou mudo até escolher o nome do seu filho e aparece no Novo Testamento" (https://www.dicionariodenomesproprios.com.br/zacarias/, acessado em 3 set. 2017). Poder-se-ia, em outro estudo, correlacionar esses elementos intervenientes na figuração da personagem protagonista do - nome e predicação - com muitas das epígrafes utilizadas por Rubião em seus contos, que remetem a textos sagrados de uma maneira geral.

A armação de mundos e submundos de personagens na literatura de Murilo Rubião constrói-se de modo singular e, particularmente, antecipador de uma ideia de produção crítica e profundamente irônica que só viria a ser percebida em seus múltiplos matizes mais tarde. $\mathrm{O}$ autor, como observa David Arrigucci Júnior, teria uma posição de precursor, pois há uma quase completa ausência de antecedentes brasileiros para o tipo de sondagem construída pelo mineiro (1993, p. 6-7). Em um arguto percurso pelo humano, o escritor confronta em suas narrativas a fragilidade do homem, tensionando os limites do imaginário, dando possibilidade aos seres ficcionais de transitarem entre o mundo dos mortos e dos vivos - "Petúnia" (RUBIÃO, 1974, p. 13-23) -; permitindo-lhes metamorfosearem-se em vários seres, inclusive em um ser humano - “Teleco, o coelhinho" (1993, p. 21-27); ou, ainda, deixando-os definhar em meio aos seus iguais, desafiado a não se tornarem autômatos diante da replicação do quotidiano - "Os Comensais" (RUBIÃO, 1974, p. 57-71).

$\mathrm{O}$ escritor traz à cena a magia, rompendo com a fixidez das certezas, principalmente ao produzir mundos possíveis ficcionais acessíveis, comuns, para corrompê-los por meio de uma verossimilhança alicerçadora na exceção. $\mathrm{O}$ exagero presente em algumas de suas personagens leva-as a questionar sua própria condição de existência antes de serem transformadas pela irrupção do insólito em seu quotidiano. Nessa construção marcada pela centralização no sujeito, Rubião transborda o aparente limite físico imposto ao conto, elaborando seres textuais tão complexos e, por vezes, ironicamente, adensados pelos vazios discursivos. 
Os processos de figuração de personagens são armados desde a definição do título dado a determinada narrativa, conforme se percebe a partir de Reis. Algumas personagens são elaboradas por conjuntos de marcas, quer físicas, quer não, bebidas nas entrelinhas narrativas, pois, sem uma apresentação formal, vão sendo geradas pelas lacunas de seu renascimento. Caso, por exemplo, da figuração em "O Pirotécnico Zacarias” (RUBIÃO, 1993, p. 11-19). Zacarias, o pirotécnico, ou seja, aquele que trabalho com fogos de artifício, provavelmente levando alegria aos outros, é o sujeito central do conto, tendo seu nome e profissão, ou ocupação, enunciado já no título.

O título de uma narrativa pode ser considerado, ele mesmo, um texto (REIS; LOPES, 2011 , p. 416 - grifo dos autor), por vezes condensado, mas capaz de evocar sentidos para o que o seguirá. É, portanto, o título o primeiro contato do leitor com um texto. De acordo com Reis e Lopes, “a relação do título com a narrativa estabelece-se muitas vezes em função da possibilidade que ele possui de realçar, pela denominação atribuída ao relato, uma certa categoria narrativa, assim desde logo colocada em destaque" (2011, p. 416 - grifo dos autor). Na narrativa de Rubião é exatamente a categoria personagem que ganha destaque, sugerindo, em certo sentido, nesse micro-texto - o título -, que se tratará da história de Zacarias.

Os mundos possíveis ficcionais que constituem a personagem são formulados pela exceção, principalmente pelo lapso temporal claramente identificável já no início da narrativa. A personagem inicia sua atuação questionando sua própria existência diante da interpretação das conversas de amigos, e diz: "raras são as vezes que, nas conversas de amigos meus, ou de pessoas das minhas relações, não surja esta pergunta. Teria morrido o pirotécnico Zacarias?” (RUBIÃO, 1993, p. 13). É, então, por meio dessa configuração que o discurso da própria personagem já se torna questionável, pois como pode um morto falar? A condição post-mortem não o impediria, por exemplo, de trocar experiências com amigos, portanto.

Na sequência, a personagem comenta:

\begin{abstract}
a esse respeito as opiniões são divergentes. Uns acham que estou vivo - o morto tinha apenas alguma semelhança comigo. Outros, mais supersticiosos, acreditam que a minha morte pertence ao rol dos fatos consumados e o indivíduo a quem andam chamando Zacarias não passa de uma alma penada, envolvida por um pobre invólucro humano. Ainda há os que afirmam de maneira categórica o meu falecimento e não aceitam o cidadão existente como sendo Zacarias, o artista pirotécnico, mas alguém muito parecido com o finado. (RUBIÃO, 1993, p. 13)
\end{abstract}

A ideia de um mundo possível ficcional, em que um morto é capaz de atribuir valores para os julgamentos em torno de sua própria morte, configura-se pela suspeição do discurso da própria 
personagem - narrador autodiético -, completamente envolvida com os acontecimentos que narra. A personagem de Rubião é, por conseguinte, o morto, mas vivo, que convive com as posições divergentes de pessoas de suas relações, nesse sentido, um alguém não excluído socialmente, apesar de talvez ser "uma alma penada, envolvida por um pobre invólucro humano".

Os processos de figuração dessa personagem vão, então, sendo traçados pelos muitos elementos que se constroem sob o olhar atento dela. Zacarias, o pirotécnico Zacarias, ou mesmo aquele que não tem mais nome, é capaz de vivenciar o quotidiano de seus amigos, conhecidos, trocando, inclusive, informações sobre sua vida ou vida de morte. Seria, com isso, um ser construído a partir de sua própria sobrevida, constituída, aparentemente, após uma morte prematura. O morto-vivo ou vivo-morto é, assim, formulado como ser de entre-lugar, afinal, não é comum alguém passar os dias a tratar das informações sobre sua própria morte.

O discurso narrativizado - "onde as palavras da personagem aparecem como um evento diegético entre outros" (REIS; LOPES, 2011, p. 318-319 - grifo dos autor) - constrói-se pela naturalidade da personagem ao tratar de sua morte. A narrativa, paulatinamente, vai adensando os sentidos dessa insólita vida, principalmente ao torná-lo o único capaz de revelar detalhes sobre como morreu. E ele questiona:

uma coisa ninguém discute: se Zacarias morreu, o seu corpo não foi enterrado. A única pessoa que poderia dar informações certas sobre o assunto sou eu. Porém estou impedido de fazê-lo porque os meus companheiros fogem de mim, tão logo me avistam pela frente. Quando apanhados de surpresa, ficam estarrecidos e não conseguem articular uma palavra.

Em verdade morri, o que vem ao encontro da versão dos que creem na minha morte. Por outro lado, também não estou morto, pois faço tudo o que antes fazia e, devo dizer, com mais agrado do que anteriormente. (RUBIÃO, 1993, p. 14)

A morte confronta, em certo sentido, a articulação da personagem que se coloca como mais ativo e, talvez, feliz que antes da morte. Fato é que Zacarias, como diz, morreu, porém é um morto mais vivo que antes da morte. E, assim, em "uma noite escura. Melhor, negra" (RUBIÃO, 1993, p. 15), o Simplício Santana de Alvarenga retorna à chamada escolar e lembrase de lições da infância ao sentir chegar à luz branca. O mundo de Zacarias mudara em uma noite escura. A personagem transita, então, por cores e sem enxergar os faróis e nem ouvir a buzina do automóvel passa a cadáver.

Na "Estrada do Acaba Mundo" (RUBIÃO, 1993, p. 15), a narrativa constrói-se pela transição da vida à morte. A figuração é elaborada por um processo dinâmico, gradual e 
complexo (REIS, 2014, p. 53), dotando a personagem de uma capacidade de perceber o tempo e o espaço em seu entorno. O mundo possível habitado pelos muitos mundos que compõem a personagem é formulado por traços insólitos e, poder-se-ia dizer, pertencentes ao plano do horror e do terror. A descrição da estrada, por exemplo, com seu nome incomum, curvas e "mais sombras que silêncio" (RUBIÃO, 1993, p. 15) denuncia a composição de um espaço estranho, por que claramente formulado para transparecer o choque entre o branco da morte e a escuridão da noite, reiterado pela personagem: "quando tudo começava a ficar branco, veio um automóvel e me matou" (RUBIÃO, 1993, p. 14); e depois: "simplesmente porque não seria naquela noite que o branco desceria até a terra" (RUBIÃO, 1993, p. 15).

As multicores visualizadas pela personagem são indícios da experiência pré-morte relatada por ela, principalmente por cessarem antes do derradeiro branco, o qual talvez o levasse ao fim. Ao contrário do esperado, ao enxergar os faróis do carro e cair sob a terra, o possível cadáver mune-se de sua confiança na faculdade de convencer seus adversários (RUBIÃO, 1993, p. 17) e põe-se em contato direto com os atropeladores para garantir a manutenção de sua sobrevida. A renovação do cadáver diante da discussão acerca de seu futuro próximo garantelhe nova disposição que, como o próprio destaca, teria adquirido após o atropelamento (RUBIÃO, 1993, p. 14).

A personagem-narrador, um “cadáver ensanguentado" (RUBIÃO, 1993, p. 16), conta passo a passo os desdobramentos pós-acidente, mencionando, inclusive, a solução, para si, mais inconveniente, que seria ser lançado ao precipício. Como diz,

discutiram em seguida outras soluções e, por fim, consideraram que me lançar ao precipício, um fundo precipício, que margeava a estrada, limpar o chão manchado de sangue, lavar cuidadosamente o carro, quando chegassem a casa, seria o alvitre mais adequado ao caso e o que melhor conviria a passíveis complicações com a polícia, sempre ávida de achar mistério onde nada existe de misterioso. (RUBIÃO, 1993, p. 17)

As demais personagens teriam por meta livrar-se do flagrante e, por conseguinte, da prova, o morto. Contudo, a construção insólita da personagem, nesse momento, já está consolidada, pois o atropelado, ensanguentado, e consciente de sua condição pós-vida, posiciona-se e afirma: “- Alto lá! Também quero ser ouvido” (RUBIÃO, 1993, p. 17). Era, portanto, o cadáver o mais preocupado, já que não teria sua morte estampada nem nas manchetes de jornal ou, ao menos, "no necrológio no principal matutino da cidade" (RUBIÃO, 1993, p. 17). Importava-lhe, então, mais a fama e a assunção de seu nome, mesmo que morto, que a continuação de sua vida. 
É, como se pode notar, uma personagem caracterizada não por um conjunto de elementos delimitadores de sua condição física e ou psíquica, e sim uma entidade fíccional elaborada para criticar a rigidez dos regulamentos para a vida e para a morte. Suas marcas vão, paulatinamente, sendo denunciadas por atitudes diante dos problemas decorrentes de seu atropelamento. Trata-se de um ser vaidoso e comum que, ao transpor da condição de vivo para defunto, vê sua percepção do mundo ser modificada, já que sente mais vivas as cores e os mundos em que se insere, antes e depois de sua transição. Criticamente, Rubião constrói uma personagem, incluída como morto entre os humanos agonizantes, porém excluída de sua antiga condição de pirotécnico, portanto, um cadáver que desfruta da vida, mas a partir de uma condição diferenciada, principalmente por sua não aceitação pelos conhecidos.

Depreende-se, assim, que a personagem rejeita a ideia de morrer tendo apenas um “improvisado túmulo" (RUBIÃO, 1993, p. 17), sem jamais ser descoberto. Seria um defunto que, como destaca, "não perdera nenhum dos predicados geralmente atribuídos aos vivos" (RUBIÃO, 1993, p. 17), e, também, por sua capacidade argumentativa, dotado de uma imensa vaidade. Se não bastasse a vitalidade presente no morto, este se integra ao grupo que o atropelara, ocupando a vaga de um dos companheiros, deixando o estatuto de morto para trocar de roupa com Jorginho (RUBIÃO, 1993, p. 18), o frágil colega desmaiado.

Rubião, em sua narrativa, traça fios de mundos e submundos emaranhados para compor um ser convivente entre dos planos divisórios de mundos, o dos mortos e o dos vivos, fazendo dialogar a física e a metafísica, ao possibilitar um corpo cadavérico poder caminhar, falar, emitir opiniões e, por fim, flertar com uma das moças. Como é comum ao percurso arquitetônico de armação de mundos rubianos, o homem ou o morto, a personagem, deseja e impulsiona-se pela possibilidade de realização.

Nessa continuidade, o defunto, agora um membro do grupo, exulta diante das mudanças permitidas por sua prematura morte e observa:

a bebida que antes da minha morte pouco me afetava, teve sobre o meu corpo defunto uma ação surpreendente. Pelos meus olhos entravam estrelas, luzes cujas cores ignorava, triângulos absurdos, cones e esferas de marfim, rosas negras, cravos em forma de lírios, lírios transformados em mãos. E a ruiva, que me fora destinada, enlaçando-me o pescoço com o corpo transmutado em longo braço metálico. (RUBIÃO, 1993, p. 18)

O vaidoso cadáver percebe as mudanças geradas pela experiência do atropelamento, confrontando seu próprio saber acerca da morte. A personagem desperta de sua semiletargia, almeja saltar no cemitério, e é impedido pelo horário de funcionamento. Mais uma vez a 
burocracia é evidenciada em narrativas de Murilo, pondo em relevo, de certo modo, as imposições sociais existentes. A impossibilidade de ficar até mesmo no cemitério coloca a personagem mais uma vez no entre-lugar, pois qual seria, de fato, a morada do atropelado? A semiletargia cede espaço para o desequilíbrio presente no defunto, que sentia medo pela morte ter penetrado em seu corpo (RUBIÃO, 1993, p. 19), ao mesmo tempo em que buscava elucidar o mistério que cercava seu falecimento (RUBIÃO, 1993, p. 19).

A personagem-narrador relata seu intenso sofrimento por frustrar-se ante a dificuldade de "convencer os amigos que [o] Zacarias que anda pelas ruas da cidade é o mesmo artista pirotécnico de outros tempos, com a diferença que aquele era vivo e este, um defunto" (RUBIÃO, 1993, p. 19). O que mais incomoda a personagem não é refletir sobre os motivos de sua morte ou sobre sua condição como vivo, ao contrário, a perturbação que acaba por prejudicar a compreensão da personagem é a não aceitação dos outros, ou seja, não ter enquanto morto o reconhecimento que tinha como vivo. A vida, segundo a personagem, ganha novas cores, contudo, não há como voltar para sua antiga existência, pois seus amigos já não o reconhecem como o pirotécnico Zacarias.

Os mundos e submundos armados por Rubião encaixam-se como um quebra-cabeça, permitindo a percepção de um mundo verossimilhante e, em certo sentido, com traços incontestáveis do mundo possível dos seres de carne e osso. A estrada escura, o mistério em torno da chegada do automóvel e, ainda, a falta de atitude do atropelado diante da impossibilidade de fugir da frente do carro deixam transparecer marcas essenciais da fragilidade humana. Sem poder impedir o inesperado choque, o atropelado, na noite escura, é a testemunha de sua própria transcendência.

Há, na narrativa do pirotécnico Zacarias, a construção de mundos que se entrecruzam, formando a exceção, visto que não se conhecem os limites entre vida e morte presentes no texto. No mundo possível ficcional elaborado, Zacarias cruzou a linha entre morte e vida, sendo o cadáver, o defunto, adiado ao sobreviver e ganhar uma existência mais colorida. Nesse sentido, o mundo sombrio, silencioso e misterioso de sua pré-morte é substituído pela variedade de cores de sua vida. No entanto, o defunto, capaz de caminhar entre os vivos, não pode voltar a seu ofício, uma vez que se tornou outro.

As muitas nuances da personagem, construídas por um percurso reiteradamente colocado em xeque, tornam sua história suspeita. Assim, os muitos elementos que compõem a personagem ganham novas proporções, gestando um ser ficcional não humano, marcado por extrapolar os sentidos comuns, corriqueiros. O cadáver, diferente e amigável, sente-se o mesmo, 
ainda que não seja percebido ou perceba o mundo à sua volta da mesma maneira. De acordo com a personagem:

Só um pensamento me oprime: que acontecimentos o destino reservará a um morto se os vivos respiram uma vida agonizante? E a minha angústia cresce ao sentir, na sua plenitude, que a minha capacidade de amar, discernir as coisas, é bem superior à dos seres que por mim passam assustados. (RUBIÃO, 1993, p. 19 - grifo nosso)

A angústia externada pelo ente ficcional ressignifica sua existência, questionando a ideia da monstruosidade que cerca o cadáver que anda e fala. No decorrer do tempo, a divisão entre morte e vida foi definindo que a inércia presente na morte e a palidez associada à falta de vida seriam componentes irrevogáveis da composição do monstro maléfico, o vampiro ou o cadáver comedor de cérebros, principalmente por trazer em si a conjugação do corpo onde já não existe mais ânimo ou anima. Entretanto, o defunto rubiano não é construído pela condição do ser cadavérico ou mesmo em decomposição, ao contrário, o mundo vivido pelo morto é menos agonizante e com um sol que pode nascer claro, "brilhando como nunca brilhou" (RUBIÃO, 1993, p. 19).

$\mathrm{Na}$ construção rubiana, a personagem compreende-se como à margem da vida, mas ainda vivo, pois imbuído de ternura. Dessa forma, o homem outrora comum capacita-se a vivenciar uma nova maneira de estar no mundo. A personagem, nessa narrativa, seria constituída pela possível superação do humano, gestando uma condição supra-real, em que sua existência pós-morte condiciona a arquitetura de um mundo de sensações mais vibrantes. Nessa perspectiva, as muitas composições dessa entidade ficcional deixam transparecer os muitos possíveis que subjazem sua natureza.

Trata-se, portanto, de uma personagem figurada por muitos traços humanizados, como o medo, o sofrimento, a angústia etc., mas supra-humano por transcender a fragilidade presente no ser humano, já que capaz de reviver após o acidente. A percepção de que a morte o tocou seria, ainda, mais um traço dessa não humanização de Zacarias que, por sua vez, torna-se outro em meio aos seus iguais, sentindo de modo diferente e, mesmo, não sendo mais reconhecido pelos companheiros. É uma personagem de múltiplas significações e marcada pelo olhar crítico e irônico para o mundo que a cerca, principalmente por perpetuar sua sobrevida por meio de um talento resguardado de sua humanidade, ou seja, o poder da argumentação.

A literatura de Murilo Rubião, apesar de inaugural, no que tange à construção do fantástico e em seu tom irônico, permaneceu por anos nas sombras, vivendo à margem de um 
cânone da literatura brasileira, seja por não ser uma produção que transite por vários gêneros, seja por sua ruptura com os modelos instituídos. Fato é que a contística de Murilo Rubião, nos últimos anos, mais que antes, ganhou nova expressão e receptividade, sendo reconhecida, principalmente, por seu caráter inaugural. Há, inclusive, a valorização da obra, também, pela necessidade de reescrita do autor.

Os mundos possíveis do insólito ficcional, território em que há a busca pela não fugacidade da experiência do inesperado, seriam os mundos em que se constituem, em geral, as histórias contadas por Rubião. Mundos estes formulados por um conjunto de estratégias capazes de inaugurar a experiência do não humano no quotidiano de uma simples personagem. A passagem do comum para o incomum instaura uma nova percepção de vida, hábil a explicitar traços da composição dos mundos e submundos possíveis existentes na configuração da personagem principal do conto rubiano.

A assunção após a queda, a construção da "divindade" depois da prematura morte, convida à reflexão sobre as estratégias imbricadas nos processos de figuração utilizados por Murilo Rubião. Em mundos possíveis ficcionais verossímeis e completamente comuns, as personagens têm suas vidas dedilhadas por uma continua presença das angústias e da produção de conflitos.

Não há descrições físicas e/ou psicológicas na narrativa, mas nomes, alcunhas, predicativos, ou seja, "dispositivos discursivos de figuração" (REIS, 2014, p. 60), que, em certo sentido, funcionam como sugestão comportamental. Cada elemento narrativo, como escolhas, diálogos, capacidade argumentativa etc., interfere na figuração da personagem. Zacarias, que empresta seu nome ao conto, com seus medos, angústias, sua capacidade argumentativa, é composto por um conjunto de elementos que desencadeiam o efeito do insólito. É, portanto, uma figura que transgride o espaço do humano ao não se autorreconhecer como igual aos companheiros, transgredindo a normalidade estabelecida no próprio conto. Assim, os mundos possíveis do insólito ficcional são construídos em Rubião pelas estratégias engendradas na produção de uma personagem tão insólita como os efeitos que produz.

Desde a epígrafe bíblica, Rubião, ao escrever: "e quando te julgares consumido, nascerás como a estrela-d'alva (Jó, XI, 17)” (RUBIÃO, 1993, p. 13), produz um efeito de leitura, visto que a consumação do corpo pela prematura morte levam a personagem experienciar outros sentidos e, assim, transitar de um plano a outro. Ao finalizar o conto, o autor, extrapolando ainda mais a possibilidade de assunção humana, permite à sua personagem a mudança quando essa diz: "a minha existência se transmudou em cores e o branco já se aproxima da terra para exclusiva ternura dos meus olhos" (RUBIÃO, 1993, p. 19). Seria, talvez, 
a aproximação da "estrela d'alva" ou a completa subida do ente caído, pertinente a leitura e interpretação bíblica? São muitas as questões que se colocam diante da leitura de uma narrativa como “O pirotécnico Zacarias” (RUBIÃO, 1993, p. 11-19).

\section{Referências}

ALBALADEJO MAYORDOMO, T. Semántica de la narración: la ficción realista. Madrid: Taurus Universitaria, 1992.

ALBALADEJO MAYORDOMO, T. Teoría de los mundos posibles y macroestructura narrativa. Alicante: Universidad de Alicante, 1998.

ANDRADE, V. L. As metamorfoses de Rubião. In: RUBIÃO, M. Contos reunidos. 2. ed. São Paulo: Ática, 1999. p. 273-276.

ARRIGUCCI JÚNIOR, D. O mágico desencantado ou as metamorfoses de Murilo. In: O pirotécnico Zacarias. São Paulo, 1993. p. 6-7.

CANDIDO, A. A nova narrativa. In: Paulo: Ática, 1987. p. 199-215. Educação pela noite e outros ensaios. São

COVIZZI, L. M. O insólito em Guimarães Rosa e Borges. São Paulo: Ática, 1978.

ECO, U. Seis passeios pelos bosques da ficção. São Paulo: Companhia das Letras, 1994.

EDER, J. “Analyzing characters: creation, interpretation, and cultural critique". Revista de Estudos Literários, Coimbra, n. 4, p. 69, 2014.

FURTADO, F. A construção do fantástico na narrativa. Lisboa: Livros Horizonte, 1980.

FURTADO, F. Fantástico (modo). In: CEIA, Carlos (Coord.). E-Dicionário de Termos Literários (EDTL). <http://edtl.fcsh.unl.pt/>. Acesso em: 26 ago. 2017.

GARCÍA, F. Aspectos dos discursos fantásticos contemporâneos, pegados "às unhas”, em um conto "não pronto para a publicação" de Murilo Rubião. In: GARCÍA, F.; BATALHA, M. C. (Org.). Murilo Rubião 20 anos depois de sua morte. Rio de Janeiro: EdUERJ, 2013. p. 1131.

GARCÍA, F. Quando a manifestação do insólito importa para a crítica literária. In: GARCÍA, F.; BATALHA, M. C. (Org.). Vertentes teóricas e ficcionais do insólito. Rio de Janeiro: Caetés, 2012. p. 13-29.

JACKSON, R. Fantasy: The Literature of Subversion. London: Routledge, 1981.

JOZEF, B. O espaço da representação. In: JOSEF, B. A máscara e o enigma. Rio de Janeiro: Francisco Alves, 2006. p. 166 
PHELAN, J. Reading People, Reading Plots. Character, Progresion, and the Interpretation of Narrative. Chicago and London: The Universit of Chicago Press, 1989.

PRADA OROPEZA, R. El discurso fantástico contemporáneo: tensión semântica y efecto estético. Semiosis, v. II, n. 3, p. 53-76, enero-junio de 2006.

REIS, C. Narratologia(s) e teoria da personagem. In: REIS, C. (Coord.). Figuras da ficção. Coimbra: Centro de Literatura Portuguesa, 2006. p. 9-23.

REIS, C. Pessoas de livro. Estudos sobre a personagem. Coimbra: Imprensa da Universidade de Coimbra, 2015.

REIS, C. Pessoas de livro: figuração e sobrevida da personagem. Revista de Estudos Literários, Coimbra, n. 4, p. 43-68, 2014.

REIS, C.; LOPES, A. C. M. Dicionário de narratologia. 7. ed. Coimbra: Almedina, 2011.

RODRÍGUEZ PEQUEÑO, J. Géneros literarios y mundos posibles. Madrid: Eneida, 2008.

RUBIÃO, M. As unhas. In: GARCÍA, F.; BATALHA, M. C. (Org.). Vertentes teóricas e ficcionais do insólito. Rio de Janeiro: Caetés, 2012. p. 125-130.

RUBIÃO, M. O pirotécnico Zacarias. In: . O pirotécnico Zacarias. São Paulo, 1993. p. 11-19.

RUBIÃO, M. Os Comensais. In: . O convidado. São Paulo: Quíron, 1974. p. 57-71.

RUBIÃO, M. Petúnia. In: . O convidado. São Paulo: Quíron, 1974. p. 13-23.

RUBIÃO, M. Teleco, o coelhinho. In: . O pirotécnico Zacarias. São Paulo, 1993. p. 21-27.

SCHWARTZ, J. Obra muriliana do fantástico como máscara. In: O convidado. São Paulo: Quíron, 1974. p. XIII- XXII.

SCHWARTZ, J. Murilo Rubião: a poética do uroboro. São Paulo: Ática, 1981.

TODOROV, T. Introdução à literatura fantástica. 2. ed. São Paulo: Perspectiva, 1992.

VIEIRA, C. Para uma nova tipologia da descrição da personagem narrativa. Revista de Estudos Literários, Coimbra, n. 4, p. 123-171, 2014. 


\title{
Sob os domínios do animal: um estudo do conto "Os dragões", de Murilo Rubião Under the animal rule: A study of the tale "Os dragões" by Murilo Rubião
}

\author{
Antonia Marly Moura Silva*
}

\begin{abstract}
RESUMO: Valendo-se da linguagem alegórica e simbólica, a literatura contemporânea tem prestigiado a representação de novos monstros e dramas humanos, invocando seu receptor para uma abertura dos horizontes de expectativa. Neste contexto, o valor atribuído aos personagens animais parece intensificar significações contidas na fronteira entre a imaginação e a realidade, afiançando o "sentimento do fantástico" a que se refere Roger Bozzetto (2001). No conto "Os dragões" (1965) de Murilo Rubião, animais expressam sentimentos e sensações tipicamente humanas, sustentando o efeito de estranhamento e de irrealidade da história narrada. Configurado com um caráter de fábula, o tom narrativo de Rubião potencializa a transgressão da realidade no movimento circular entre o normal e o anormal, o verdadeiro e o falso, o possível e o impossível, enaltecendo o estatuto da indecidibilidade que marca o fantástico contemporâneo. Sob tal perspectiva, este trabalho pretende analisar $o$ referido conto, dando destaque ao modo de figuração do fantástico à luz do pensamento de autores como Finné (1980), Julio Cortázar (1993), David Roas (2001, 2011, 2014), Remo Ceserani (2006) e Irene Bessière (2005).
\end{abstract}

PALAVRAS-CHAVE: Murilo Rubião. Conto fantástico. Metáfora do animal.

\begin{abstract}
Using allegorical and symbolic language, contemporary literature has seen the representation of new monsters and human dramas, invoking its interpreter for an opening of the horizons of expectation. In this context, the value given to the animal characters seems to intensify meanings that lie on the border between imagination and reality, securing the "feeling of the fantastic" referred to by Roger Bozzetto (2001). In Murilo Rubião's tale "Os dragões" (1965), animals express feelings and sensations that are typically human, supporting the strangeness and unreality effect of the story. With the status of a fable, Rubião's narrative tone enhances the transgression of reality in the circular movement between normal and abnormal, true and false, possible and impossible, exalting the position of undecidability that characterizes the contemporary fantastic. In this perspective, this work aims at analyzing the aforementioned tale, highlighting the figuration mode of fantastic, according to authors such as Finné (1980), Julio Cortázar (1993), David Roas (2001, 2011, 2014), Remo Ceserani (2006), and Irene Bessière (2005).
\end{abstract}

KEYWORDS: Murilo Rubião. Fantastic tale. Animal metaphor.

\section{Introdução}

Na modernidade, o encontro harmonioso entre literatura e imaginário e a evolução de procedimentos estéticos, formais e temáticos, alargaram o modo de desenhar o discurso

\footnotetext{
* Doutora em Letras pela Universidade de São Paulo (2001), Pós-Doutora pela Universidade de Coimbra-PT (2016-2017), Docente permanente do Progrma de Pós-Graduação em Ciências da Linguagem (PPCL), vinculada ao Departamento de Letras Vernáculas da Universidade do Estado do Rio grande do Norte (DLVqUERN).
} 
romanesco e protagonizar o irreal, ampliando ainda mais a discussão em torno da natureza da narrativa fantástica. Neste cenário, é oportuno sublinhar os desígnios do sobrenatural expresso em poéticas contemporâneas, cuja ênfase recai em aspectos da condição humana e em figurações localizadas no liame do possível e do impossível, do estranho e do familiar, distanciadas, pois, dos padrões e das formas épicas do passado.

No fantástico compreendido como contemporâneo, o caráter paradoxal da mimese torna possível o questionamento da oposição entre real e irreal. Pelo critério da transgressão, a literatura rompe com esse sistema binário de oposição, favorecendo a noção de que "o fíctício é uma realidade que se repete pelo efeito do imaginário, ou que o fictício é a concretização de um imaginário que traduz elementos da realidade" (BRANDÃO, 2013, p. 34).

Em termos teóricos, indagações a respeito da natureza do fantástico desembocam numa pluralidade de concepções que cercam a literatura voltada para a expressão do sobrenatural. No debate, a importância dada às fronteiras entre formas narrativas que se aproximam na expressão de realidades insólitas ensejou um argumento: a noção de que a literatura fantástica conjuga, pela força da alegoria e do símbolo, incertezas e enigmas da vida moderna imbricadas pelo extraordinário. Assim, cumpre valorizar o cotidiano e a realidade que se aproxima daquela vivida pelo leitor. Para tanto, o leitor deve ser guiado por uma lógica interna da narrativa e pelo “acordo ficcional" firmado com o autor, tal como defende Umberto Eco (1994, p. 83), pois o relato fantástico constitui-se como representativo da vida, um retrato da realidade que os seres ficcionais - e também o leitor - concebem como familiar. Propõe-se, assim, que se pense o fantástico segundo a lógica da fusão de realidades, quando o natural e o sobrenatural se misturam de modo harmonioso.

Entre os estudiosos do fantástico vamos encontrar uma definição básica: a noção de que o acontecimento insólito é o elemento desagregador da realidade ordinária, o responsável pela quebra das leis que regem o mundo real. Para Castex (1951, citado por Magalhães Júnior, 1972, p. 66), por exemplo, o fantástico se caracteriza "por uma intrusão brutal do mistério dentro dos quadros da vida real, e este geralmente ligado aos estados mórbidos da consciência, que nos fenômenos de pesadelo ou delírio, projeta diante dela própria as imagens de seus terrores e de suas angústias". Portanto, o fantástico ocorre quando um fenômeno de outra dimensão surge em um mundo semelhante ao nosso, esse fenômeno é o que configura o estatuto do sobrenatural. Tal concepção ganhou certa popularidade. Roas (2014) defende um ponto de vista que se aproxima da definição de Castex, para o espanhol o fantástico diz respeito, “[à]quilo que transgride as leis que regem o mundo real e não pode ser explicado porque não existe segundo essas leis (ROAS, 2014, p. 25). 
É, pois, importante considerar uma aliança entre o real e o sobrenatural, uma vez que o real é concebido como fundamental para a composição da atmosfera fantástica.

Uma outra abordagem ressalta o caráter relacional entre o literário e o social, tomando como referência o fato de que a realidade é construída histórica e culturalmente, e, sobretudo, que o fantástico evolui, tal como a literatura e a sociedade, pois conforme Jacques Finné (1980, p. 14) [c]omme tout genre littéraire, le fantástique n'est pas statique. Il a évolué, au cours de sa breve existence, à tel point qu'il mériterait non une thése, mais une série de théses". Assim, o estudioso francês nos chama a atenção para a concepção de literatura e, em particular, para o sentido de "fantástico".

Pode-se dizer, de um modo geral, que é próprio da narrativa fantástica a expressão de um cenário realista que assegure a confluência de realidades - a verossímil e a inverossímil. Poderíamos, assim, começar nos indagando sobre o estatuto da mimese ou sobre o "pacto ficcional", conforme Eco (1994) que é estabelecido com o leitor. O modo de expressão da realidade, portanto, parece determinar o caráter insólito da literatura, pois, é importante ressaltar: enquanto o realismo firma um contrato mimético com a realidade, o fantástico transgride essa realidade, pois, não tem compromisso com a verdade. Porém, para que o insólito se aloje, o relato deve ser crível, o que nos faz lembrar a posição oportuna de Ítalo Calvino (2011, p. 9):

O fantástico diz coisas que se referem diretamente a nós, embora estejamos menos dispostos do que os leitores do século passado a nos deixarmos surpreender por aparições fantasmagorias, ou melhor, estamos prontos a apreciá-las de outro modo, como elementos da cor da época.

Nesta perspectiva, consideramos que no conto “Os dragões” de Murilo Rubião o leitor encontra terreno fértil para uma reflexão sobre as potencialidades do ordinário e do extraordinário e, em particular, da relação entre homem e bicho. $\mathrm{O}$ conto oferece grandes possibilidades de análise dos aspectos fantásticos.

Num universo fabular que se opõe aos discursos mais racionalistas, o esfacelamento dos seres ficcionais funcionam como catalisador na apreensão de domínios poéticos que se aproximam do absurdo. No desenho da (ir)realidade, confere-se à história uma atmosfera anormal num mundo aparentemente normal. Assim, o absurdo e a fantasia cumprem a função de deflagrar uma nova noção de real, calcada num quadro de referências simbólicas que inscrevem a dimensão irônica e crítica do conto de Rubião. Esse modo romanesco de representar a realidade realça, por um lado, aspectos sobre a realidade social moderna, e, por 
outro lado, suscita reflexões sobre os dramas dos personagens, seres aparentemente normais em total descompasso com o mundo e, por isso, em situação de desequilíbrio em relação ao que enfrentam.

É, pois, seguindo tal pensamento, que faremos uma leitura do referido conto, buscando compreender traços do fantástico na arquitetura ficcional.

\section{Arredores do fantástico}

De natureza controversa por avizinhar-se de outras espécies de narrativas que rompem com os limites do real, a relação de contiguidade entre o real e o sobrenatural dividem os estudiosos da área na tentativa de definir as fronteiras, o sentido e o efeito do fantástico. $\mathrm{Na}$ tradição da literatura, a presença de eventos sobrenaturais demarcou o modo de figuração da realidade, definindo a natureza do contrato mimético - verossímil ou inverossímil.

A capacidade inventiva de figurar o natural e o sobrenatural, o ordinário e o extraordinário se converte em formas romanescas inusitadas reveladoras das mais diferentes situações. Tal como a literatura, o fantástico evolui de acordo com a sociedade, denota novas configurações da realidade e extrapola os limites do ficcional e do imaginário na tentativa de compor um desenho fabular atual da subjetividade e das experiências de vida. Tal perspectiva nos faz lembrar da afirmação oportuna de Irène Bessière (2009, p. 3):

O relato fantástico utiliza marcos sócio-culturais e formas de compreensão que definem os domínios do natural e do sobrenatural, do banal e do estranho, não para concluir com alguma certeza metafísica, mas para organizar o confronto entre os elementos de uma civilização relativos aos fenômenos que escapam à economia do real e do surreal, cuja concepção varia conforme a época.

Bozzeto (1992 apud Huftier, 2004, p. 37) por sua vez afirma:

Dans le fantastique antérieur, on rencontrait une Surnature connue, répertoriée, presente, solide, et - à la limite - disponible. [...] Dans le fantastique moderne, la Surnature n'apparaît pas comme telle. Quelque chose d'absurde, d'irrationnel se produit, certes, et n'est pas perçu comme irruption d'une ordre supérieur mais plutôt comme un ennui, une pertubation, un désastre qui s'insinue en d'infimes failles subvertissant les bases supposées normales de la quotidienneté.

Frente a isso, podemos dizer, à luz de Bozzeto, que a literatura fantástica mais recente demonstra uma predileção discursiva pelo desconhecido, pelo o estranho e pelo absurdo, 
essência da literatura fantástica que, segundo o escritor Calvino, reside na confluência de realidades. Sob tal enfoque, assim declara Calvino (2011, p. 9):

O problema da realidade daquilo que se vê - coisas extraordinárias que talvez sejam alucinações projetadas por nossa mente; coisas habituais que talvez ocultem sob a aparência mais banal uma segunda natureza inquietante, misteriosa, aterradora - é essa a essência da literatura fantástica, cujos melhores efeitos se encontram na oscilação de níveis de realidades inconciliáveis.

É nesse universo inquietante, extraordinário e mágico que "o sentimento fantástico", tal como concebe Roger Bozzetto (2001), se sustenta. O fantástico elimina a possibilidade de estar a serviço da razão e da ciência, visto que importa o caráter inverossímil da realidade e o fortalecimento do sobrenatural e dos eventos insólitos representados. Nesta perspectiva, é possível dizer, de acordo com Nodier (2005, p. 34), que as "questões sobre o fantástico são propriamente do domínio da fantasia". A natureza influente da fantasia é, pois, o elemento de nutrição do modo fantástico, uma vez que esse "exige à verdade uma virgindade de imaginação e de crenças" (NODIER, 2005, p. 22).

Sob tal viés, os relatos fantásticos lançam mão de ingredientes ficcionais que libertam a literatura do compromisso com um contrato mimético ou do caráter impositivo da verossimilhança para se instalar no entre-lugar da fantasia e da realidade, o que nos faz lembrar a declaração oportuna de Irène Bessière (2005, p. 2):

O relato fantástico provoca a incerteza ao exame intelectual, pois coloca em ação dados contraditórios, reunidos segundo uma coerência e uma complementaridade próprias. Ele não define uma qualidade atual de objetos ou de seres existentes, nem constitui uma categoria ou um gênero literário, mas supõe uma lógica narrativa que é tanto formal quanto temática e que, surpreendente ou arbitrária para o leitor, reflete, sob o jogo aparente da invenção pura, as metamorfoses culturais da razão e do imaginário coletivo.

É importante dizer que a celeuma em torno da natureza do fantástico não é nova. É com Tzvetan Todorov em 1970, particularmente com sua Introdução a literatura fantástica, que se deu a caracterização estruturalista do fantástico. Assim afirma Todorov (2008, p. 15):

Em um mundo que é o nosso, [...] se produz um acontecimento impossível de explicar pelas leis desse mesmo mundo familiar. [...]. ou se trata de uma ilusão dos sentidos, de um produto de imaginação, e as leis do mundo seguem sendo o que são, ou o acontecimento se produziu realmente, é parte integrante da realidade, e então esta realidade está regida por leis que desconhecemos. 
Na perspectiva todoroviana, a hesitação constitui condição sine qua non experimentada pelos seres ficcionais diante de um acontecimento sobrenatural. Segundo Todorov, esta é a marca definidora da narrativa fantástica. Tal pensamento amarra uma relação com a razão para delimitar fronteiras entre outras instâncias como o maravilhoso e o estranho. Na definição do fantástico, assim declara o estudioso (TODOROV, 2008, p. 15): “O fantástico ocupa o tempo desta incerteza. Assim que se escolhe uma das duas respostas, deixa-se o terreno do fantástico para entrar em um gênero vizinho: o estranho ou o maravilhoso".

$\mathrm{Na}$ atualidade, conforme ressalta Jesús Rodero (2006), embora reconhecendo a importância e o caráter precursor dos princípios teóricos formulados por Todorov, estudiosos pós-estruturalistas relacionam o fantástico com a transgressão de valores culturais. Segundo Rodero (2006, p. 2).

lo fantástico en literatura se presenta como indefinible, lo inasible, aquillo que cuestiona y transgrede nuestra concepción occidental, lógica y racional del universo, aquello que subvierte y resquebraja las normas de funcionamiento tanto de la realidad como de lo sobrenatural. Aquí encontramos ya varios de los términos que se repiten entre la critica reciente: cuestionamento, subversión, transgresión/subversion del sentido común y del racionalismo aristotélico.

É, pois, no entrecruzamento de realidades, na confluência do desconhecido com o conhecido e na diluição de fronteiras entre o estranho e o familiar que o fantástico se aloja. $\mathrm{O}$ efeito de irrealidade, portanto, depende do estatuto da realidade que acentua o caráter de ilusão. Daí a ocorrência de um fantástico “em que o sobrenatural permanece invisível, é mais 'sentido' do que 'visto', participando de uma dimensão interior, como estado de ânimo ou como conjectura" (CALVINO, 2011, p. 13).

Frente a indecidibilidade do modo fantástico quanto ao questionamento da coexistência entre o natural e o sobrenatural, o possível e o impossível, dentro e fora do texto, assim se posiciona Roas (2014, p. 103):

a diferença reside no fato de o fantástico problematizar os limites entre realidade e irrealidade (ou ficção), enquanto a narrativa pós-moderna (falando em um sentido muito geral) os apaga, harmonizando, portanto, aquilo que identificaríamos como real e aquilo que identificaríamos como imaginário.

Porém, é importante dizer ainda que o elemento sobrenatural é o traço definidor do relato fantástico, pois "La presença de lo sobrenatural o irreal (o lo que la convención social y 
cultural entiende por sobrenatural o irreal) en la realidad narrada es essencial par distinguir lo fantástico de esos otros modos narrativos mencionados" (RODERO, 2006, p. 3).

Conforme David Roas (2011, p. 14), o fantástico vai depender sempre da noção que temos de realidade, pois,

el relato fantástico sustituye la familiaridad por lo extraño, nos sitúa inicialmente en un mundo cotidiano, normal (el nuestro), que inmediatamente es asaltado por un fenómeno imposible - y, como tal, incomprensible - que subvierte los códigos - las certezas - que hemos diseñado para percibir y comprender la realidad. En definitiva, destruye nuestra concepción de lo real y nos instala en la inestabilidad y, por ello, en la absoluta inquietud.

Em outras palavras, fatos estranhos se confluem com aquilo que é considerado familiar e corriqueiro e, assim, não causam nenhuma surpresa nos seres ficcionais. Camuflado em aspectos cotidianos, o irreal não destoa uma vez que se integra à história como se pertencesse aos fatos ordinários e, por isso, naturalizados. Segundo Ceserani (2006, p. 71), o fantástico surge no "mundo familiar, aceitável, pacífico, para depois fazer disparar os mecanismos da surpresa, da desorientação, do medo". Esta situação contribui para que alguns teóricos contestem a hesitação apontada por Todorov como um dos aspectos determinantes do fantástico. Conforme Roas (2014, p. 53), o fantástico se instaura quando há a transgressão das leis que definem a realidade, pois "o objetivo fundamental de toda narrativa fantástica é questionar a possibilidade de um rompimento da realidade empírica".

\section{Bichos humanizados ou opostos complementos: o conto "Os dragões”}

Eleger a obra de Murilo Rubião para ilustrar aspectos do fantástico pode parecer um lugar comum, pois sua extensa e vasta fortuna crítica revela a dimensão do interesse da crítica pelo seu legado literário. Porém, é importante ressaltar, repetindo o que é dito no prefácio da obra completa do escritor, publicada pela Companhia das Letras (2010, p. 8), que "Embora seus livros tenham começado a ser publicados há mais de cinquenta anos e sido elogiados por importantes escritores e críticos, a obra de Murilo Rubião ainda é pouco conhecida por leitores brasileiros".

Murilo Eugênio Rubião (1916-1991), escritor, notadamente reconhecido pela engenhosidade no modo de narrar e, sobretudo, pela originalidade na transgressão do real, é apontado como o precursor do fantástico moderno na literatura brasileira. Mineiro, nascido no Carmo de Minas, iniciou o curso de direito, mas foi o jornalismo e a literatura que o fisgaram 
para uma vida dedicada ao exercício da escrita. Com uma obra pouco extensa e dedicada ao conto, ao todo trinta e três contos, meticulosamente escritos e reescritos ao longo de sua carreira, o escritor demonstrou o labor e a técnica com que compunha sua arte poética. Embora tendo iniciado como escritor na década de 30, somente estreou em 1947 com a obra $O$ ex-mágico e outros contos", considerado o marco inicial da literatura fantástica no Brasil. O escritor permaneceu desconhecido do grande público até 1974 com o lançamento de $O$ pirotécnico Zacarias, livro com o qual o escritor primeiro teve o reconhecimento da crítica latinoamericana.

O conto "Os dragões", inicialmente publicado no livro Os dragões e outros contos (1965), é o sétimo conto da coletânea Murilo Rubião, obra completa (2010). No relato, a humanização de personagens dragões converge, técnica e engenhosamente, para consolidar a atmosfera de realidade do relato. Figura emblemática em contos de fadas, no mito e na literatura, no conto de Murilo Rubião os dragões são seres com habilidades para o estudo e para o trabalho; falam, agem e vivem em sociedade como um ser humano disfarçado, configurando um desenho inverossímil da realidade.

Narrado em terceira pessoa, os dragões chegam a uma cidade, não nomeada, e, de imediato, não são aceitos pela comunidade, apenas as crianças, que não são ouvidas, concebemnos como simples dragões e companheiros para as brincadeiras. É o vigário quem provoca a controvérsia, pois, embora ciente da aparência dócil e meiga dos dragões, insinua que são enviados do demônio. O velho gramático, por sua vez, qualifica-os como “"coisa asiática de importação europeia"”(RUBIÃO, 2010, p. 47). Na ausência de um consenso e de objetivos práticos em relação a permanência dos intrusos na cidade, conforme o narrador o "cansaço e o tempo venceram a teimosia de muitos" (RUBIÃO, 2010, p. 47). Mas, é o padre quem encerra a discussão com a determinação de que eles receberiam nome e seriam batizados. Assim, os animais podem ser inseridos na cultura e na religião, assumindo direitos e deveres, ou seja, eles adquirem uma identidade jurídica e também os direitos de cidadania, pois firmam um contrato social, necessário para serem acolhidos, pois, para terem direito à hospitalidade, o animal precisa, antes, preencher as condições estabelecidas pela comunidade.

No conto, os dragões contraem doenças e morrem, somente dois deles - Odorico e João - sobrevivem. Na ação dos personagens, os animais são figurativizados como uma alegoria do homem mundano. Adeptos da vida noturna, boêmios e beberrões, são frequentadores assíduos de um botequim, daí a ressaca alcoólica e as noites mal dormidas que são motivos do constante mau humor dos dois. Odorico, o mais velho e mais libertino, é um mulherengo nato, apreciador de mulheres casadas. João, que permanece na cidade mais tempo, é dedicado ao estudo, às 
tarefas domésticas, mas também desperta a simpatia entre moças e rapazes do lugar. Logo, na primeira linha do conto, o narrador apresenta a chegada dos dragões, criando a expectativa no leitor de que outros viriam depois. "Os primeiros dragões que apareceram na cidade muito sofreram com o atraso dos nossos costumes" (RUBIÃO, 2010, p. 47). No decorrer da narrativa, a oposição nativo e forasteiro adquire uma atmosfera de normalidade em relação à convivência dos moradores do lugar com os "estrangeiros". A hospitalidade dos nativos cria a perspectiva de acolhimento, daí os sentimentos de aceitação e o desejo de pertencimento ao lugar na relação harmoniosa entre os humanos e os dragões.

depois disso muitos dragões têm passado pelas nossas estradas. E, por mais que eu e meus alunos, postados na entrada da cidade, insistamos que permaneçam entre nós, nenhuma resposta recebemos. Formando longas filas, encaminham-se para outros lugares, indiferentes aos nossos apelos. (RUBIÃO, 2010, p. 51)

O trânsito livre na cidade configura o local como um reduto dos animais, acentuando o caráter fortuito de banalização. Tudo isso serve para instaurar a perspectiva de realidade num cenário totalmente inverossímil. A congruência da realidade com a irrealidade se verifica no ato do dragão vomitar fogo, algo totalmente natural por tratar-se de um dragão. O gesto não surpreende o leitor, pelo contrário, a habilidade natural do animal "fez crescer a simpatia que gozava entre as moças e rapazes do lugar" (RUBIÃO, 2010, p. 50). A "proeza", assim referida pelo narrador, é naturalizada no cotidiano da cidade e logo adquire estatuto de brincadeira e oportunidade de trabalho no circo local.

$\mathrm{Na}$ narrativa, todas as habilidades do dragão são apontadas pelo narrador como uma qualidade, por isso "o prestigio que desfrutava na localidade" (RUBIÃO, 2010, p. 50). Mesmo assim, sujeito social e cidadão, o dragão empreende a fuga, desaparece como um errante que abandona o carinho e o acolhimento de todos pelo amor de uma trapezista, seduzido pelo jogo de cartas e pelo vício da bebida. Assim, se encerra o drama do dragão que teve, inclusive, a pretensão de ser prefeito do município.

De um modo geral, no conto "Os dragões" os animais são integrados à vida daqueles que os acolheram. O animal experimenta uma vida civilizada como humano, num cotidiano citadino e realista.

A naturalização do irreal, tal como é configurado no relato, parece constituir-se como mais uma forma de provocar um pacto com o leitor. Possivelmente, um modo de instigá-lo a refletir sobre a essência, a função e a natureza da literatura; de suscitar reflexões para além da 
imanência da obra, realçando a evolução de códigos estéticos e, sobretudo, a relação de contiguidade entre literatura e sociedade, passado e presente, literatura e mito, razão e desrazão.

\section{Referências}

BESSIÈRE, I. O relato fantástico: forma mista do caso e da advinha. Tradução de Biagio D’Angelo e Maria Rosa Oliveira. Fronteiraz, São Paulo, n. 101, p. 1-18, 2009.

BOZZETTO, R. Le fantastique dans tous ses états. Aix-en-Provence: Publications de L’Université de Provence, 2001.

BOZZETTO, R. L'obscur objet d'un savoir: fantastique et science-fiction, deux littératures de l'imaginaire. Publications de l'Université de Provence, 1992.

BOZZETTO, R.; HUFTIER, A. Les frontières du fantastique: approches de l'impensable em littérature. Paris: Presses Universitaires de Valenciennes, 2004.

BRANDÃO, L. A. Teorias do espaço literário. São Paulo: Perspectiva; Belo Horizonte: FAPEMIG, 2013.

CALVINO, I. Introdução. In: . Contos fantásticos do século XIX: o fantástico visionário e o fantástico cotidiano. São Paulo: Companhia das Letras, 2011. p. 9-18.

CESERANI, R. O fantástico. Curitiba: Editora UFPR, 2006.

ECO, U. Bosques possíveis. In: Companhia das Letras, 1994. p. 81-102. . Seis passeios pelos bosques da ficção. São Paulo:

FINNÉ, J. La littérature fantastique: essai sur l'organisation surnaturelle. Bruxelas: Ed. de l’Université de Bruxelles, 1980.

HUFTIER, A. Fantastique, fantastic, fantastiche, fantástica, fantástico... Derivas ocidentais de uma palavra. In: SIMÕES, M. J. (Coord). O fantástico. Coimbra: Centro de Literatura Portuguesa, 2007. p. 43-41.

HUFTIER, A. Les avatars d'une notion: le fantastique moderne. In. BOZZETTO, R.; HUFTIER, A. Les fronteires du fantastique: approches de l'impensable em littérature. Paris: Presses Universitaires de Valenciennes, 2004. p. 31-48.

MAGALHÃES JÚNIOR, R. O conto fantástico. In: . A arte do conto: sua história, seus gêneros, sua técnica, seus mestres. Rio de Janeiro: Bloch, 1972. p. 62-92.

NODIER, C. Do fantástico em literatura. Tradução de Osório, M. R. B. \& Meregalli, M. L. Organon, Porto Alegre, n. 19 (38/39), p. 19-35, 2005.

ROAS, D. Tras los limites de lo real: uma definição de lo fantástico. Madrid: Páginas de Espuma, S. L, 2011. 
ROAS, D. A ameaça do fantástico: aproximações teóricas. São Paulo: Editora da UNESP, 2014.

RODERO, J. La edad de la incertidumbre: um estudio del cuento fantástico del siglo XX en latinoamérica. New York: Peter Lang Publishing, 2006.

RUBIÃO, M. Obra completa. São Paulo: Companhia das letras, 2010.

TODOROV, T. Introdução à literatura fantástica. 3. ed. São Paulo: Perspectiva, 2008. 


\section{Os lados do círculo em "Os três nomes de Godofredo", de Murilo Rubião The sides of the circle in "Os três nomes de Godofredo" by Murilo Rubião}

Raul da Rocha Colaço*

\begin{abstract}
RESUMO: Este trabalho se pauta na investigação da figura geométrica do círculo no conto "Os três nomes de Godofredo", de Murilo Rubião. Para isso, dialogamos com diversas áreas do saber (Matemática, Artes Plásticas, Física, Psicologia, entre outras) e dividimos o trabalho nos seguintes tópicos: 1) Andando em círculos: o ciclo labiríntico do espaço, da ação e do tempo (abarca tanto as ações repetitivas dos personagens e os seus deslocamentos circulares, quanto o tempo que se aproxima do mítico, no qual passado, presente e futuro constituem um só tempo); 2) Circunferência retabular (resgate da ideia de "tudo ao mesmo tempo e agora", todos os eventos expostos num mesmo plano); 3) Círculo escrito, circunscrito (análise das menções às figuras circulares e a tudo o que remete a elas); 4) Circuito em série: a relação texto e epígrafe (abrange a influência recíproca entre as epígrafes e a narrativa abordada, num jogo circular infinito). Assim, nos foram úteis, principalmente, os estudos de Robert Cumming (1996), de Gotthold Ephraim Lessing (1998), de Carl Gustav Jung (2008) e de Jorge Schwartz (1981). No que concerne aos resultados, assinalamos que o círculo funciona como elemento norteador do conto ora analisado, na medida em que Rubião se aproveita do círculo para deformá-lo, abrindo, assim, fendas para a inserção do leitor no seu texto.
\end{abstract}

PALAVRAS-CHAVE: Geometria. Círculo. Circunferência. Murilo Rubião.

\begin{abstract}
This article aims to analyze the geometric figure of the circle in Murilo Rubião's short story "Os três nomes de Godofredo". To this end, we dialogue with different areas of knowledge (Mathematics, Plastic Arts, Physics, Psychology and others) in four topics: 1) Walking in circles: the labyrinth cycle of space, action and time (including both the characters' repeated actions and circular displacements and the time that approaches the mythical space where past, present and future are just as one; 2) The retable circumference (the rescue of the idea of "all at once and now," all the events on the same plan); 3) The written, circumscribed circle (na analysis of mentions to the circular figures and everything that refers to them); 4) Serial circuits: the text-epigraph relationship (including the reciprocal influence between epigraphs and the narrative in an infinite circular game). Studies by Robert Cumming (1996), Gotthold Ephraim Lessing (1998), Carl Gustav Jung (2008) and Jorge Schwartz (1981) were useful to the presente analysis. The findings point out that the circle works as a guiding element of the short story, inasmuch as Rubião takes advantage of the circle to deform it, opening up cracks for the introdution of the reader to his text.
\end{abstract}

KEYWORDS: Geometry. Circle. Circumference. Murilo Rubião.

\footnotetext{
* Mestrando do curso de Teoria da Literatura do Programa de Pós-graduação em Letras da Universidade Federal de Pernambuco (UFPE), onde realiza a pesquisa, sob orientação da Profa. Dra. Brenda Carlos de Andrade, "As ruínas circulares de Amilcar Bettega Barbosa e de Murilo Rubião", na qual se dedica a investigar a figura geométrica do círculo em ambos autores. E-mail: rauldarochacolaco@gmail.com.
} 
Traçou um círculo à superfície das águas, onde a luz confina com as trevas. As colunas do céu estremecem e assustam-se com a sua ameaça.

(Jó, XXVI, 10-11)

\section{Introdução}

Wadji Mouawad, no prefácio de sua obra Incêndios (2013), intitulado "Um consolo impiedoso", afirma retomar a questão da origem, que tanto o persegue. Essa preocupação também costuma importunar, com regularidade afiada, os envolvidos neste trabalho. E, após a leitura desse texto incendiário, o desconforto aumentou: deixou de chamuscar restritamente o ponto de partida da história dos que escrevem estas linhas para engolir, com fúria, o princípio da existência literária do seu autor predileto: o mágico de Carmo de Minas, o pirotécnico Murilo Rubião.

Apesar de figurar-se, no âmbito da literatura brasileira, como "antena da raça", no que diz respeito à literatura fantástica e, mais além, à ficcionalização do absurdo do cotidiano, o mágico Rubião nasceu, profisssionalmente, nos berços jurídicos. Ao duplicar-se entre estes dois palcos, o burocrático e o literário, o escritor mineiro extraiu da cartola o seu trunfo: a "busca desesperada pela clareza", como afirmara numa entrevista ${ }^{2}$.

Com relação a esse número artístico, damos destaque ao seu principal método: a reescrita. Para seduzir a plateia leitora, Murilo Rubião reescrevia seus textos à exaustão, retirando qualquer possível excesso - tão comum em âmbitos jurídicos —, para que sua linguagem funcionasse como um soco no estômago do leitor (situação inversa a de Harry Houdini, que recebia os socos dos espectadores para provar sua resistência) e levasse a pessoa golpeada a nocaute. ${ }^{3}$

\footnotetext{
${ }^{1}$ Denominação atribuída por Ezra Pound, na obra $A B C$ da literatura (2013), aos escritores, pois eles atuam como um alarme preditivo que aponta direções proveitosas para o seu povo, bem como um radar sensível às mazelas que poderão levar a comunidade à falência.

2 Jorge Schwartz, no posfácio de O pirotécnico Zacarias e outros contos (2006), afirma que o trecho entre aspas está presente na entrevista que Murilo Rubião concedeu a J. A. Granville Ponce em O pirotécnico Zacarias (1974). Contudo, ao fazermos a checagem desta informação, não encontramos o fragmento mencionado. Mesmo assim, preferimos manter a expressão, pois resume, em poucas palavras, um traço de suma importância para o entendimento da obra rubiana.

${ }^{3}$ Segundo afirma Julio Cortázar: "Um escritor argentino, muito amigo do boxe, dizia-me que nesse combate que se trava entre o texto apaixonante e o leitor, o romance ganha sempre por pontos, enquanto que o conto deve ganhar por knock-out" (CORTÁZAR, 2006, p. 152).
} 
Então, diante da investigação minuciosa da obra de Murilo Rubião, encontramos, para além dos estudos do fantástico em suas narrativas, um ponto de partida ainda pouco explorado: a utilização recorrente do círculo. Em outros termos, constatamos que esse autor se aproveita desse recurso geométrico para constituir os seus contos: seja por meio de uma sintaxe circular (sequência considerável de frases que envolvem um mesmo tema, com o intuito de contornar todo o assunto abordado); seja através de um enredo que sempre retorna ao início da fábula; seja pela apropriação de um tempo mítico e/ou circular ficcionalizado; seja pelos personagens que, muitas vezes, aparentam andar em círculos; seja no uso de nomenclaturas que remetam à essa figura etc.

Após essa descoberta, passamos ao levantamento da fortuna crítica do autor, com a intenção de se confirmar a relevância deste inquérito. Salvo pelo trabalho de Schwartz (1981), que se espraia pelo tema do uroboro e, assim, toca levemente na figura do círculo, não mapeamos nenhum trabalho que se inclinasse nessa linha. Em outras palavras, os materiais que abarcam a geometria circular e, por extensão, a geometria circunferencial de Murilo Rubião praticamente inexistem. Sendo assim, este trabalho visa a minimizar essa carência encontrada no âmbito da Crítica Literária de Língua Portuguesa e, para isso, abordaremos, detalhadamente, o conto intitulado "Os três nomes de Godofredo", de O ex-mágico (1947), livro de estreia do autor mineiro.

Além disso, é válido anunciarmos, de modo prévio, os flancos de abordagem adotados nesta pesquisa, na seguinte ordem: o labirinto circular do espaço, da ação e do tempo; o conto e a estrutura semelhante a um retábulo em formato circular; o emprego de termos que se relacionam com o círculo e/ou a circunferência; e a relação circular da epígrafe com o texto e do texto com a epígrafe.

\section{Andando em círculos: o ciclo labiríntico do espaço, da ação e do tempo}

Para uma discussão mais cristalina e mais detida, preferimos desmembrar este tópico em duas partes. A primeira delas se espraia sobre o espaço e a ação, enquanto a segunda se volta para o tempo. Entretanto, não desconsideramos, em nenhum momento, que todas essas instâncias se contaminam e se influenciam reciprocamente. 


\subsection{Lado Um: espaço e ação}

Para dar início à jornada que se estenderá pela circunferência mestra do conto "Os três nomes de Godofredo", fazemos um breve resumo dessa obra com o intuito de contextualizar o que será debatido neste tópico. Desse modo, dividimos a diegese em três partes. A primeira delas abarca o instante inicial da narrativa, em que Godofredo (que a esta altura é chamado por João de Deus) está num restaurante e uma mulher desconhecida se senta na mesma mesa em que ele se encontra; o homem decide trocar de mesa, para continuar jantando solitário, mas ela o acompanha; depois, essa mulher, que se chama Geralda, afirma ser a sua segunda esposa e lhe revela que ele assassinou a primeira; ao final da refeição, os dois vão para a mesma casa e dormem juntos por vários dias, até caírem na rotina e retornarem a tomar refeição no restaurante (sempre em silêncio); por fim, regressam, num dia qualquer, à residência em que vivem e João de Deus acaba enforcando-a.

O segundo bloco se ramifica em duas seções. A primeira se apresenta através primeiro ato executado por João de Deus após a morte de Geralda: retornar ao restaurante. Ao chegar nesse ambiente, o protagonista encontra uma mulher muito parecida com sua ex-esposa e se dirige a ela. Em pouco tempo de conversa, a mulher afirma ser a primeira esposa de João de Deus (que, para ela, chama-se Robério) e lhe relembra que ele acabou de matar a segunda num acesso de ciúmes. Surpreso com a notícia, Robério chama, instintivamente, a mulher pelo seu nome, Joana, e passar a gritar no recinto; em seguida, Joana lhe diz que o restaurante está vazio e que o pai dela o comprou para ele. Assustado com as revelações, sai correndo em direção a sua casa.

Agora, chegamos à segunda seção, que tem seu princípio no momento em que Godofredo chega em casa (e depara com uma mulher no corredor semelhante às outras duas esposas) e se encerra no instante em que o homem abraça a jovem, com tristeza, e a estrangula. Após esse assassinato, atracamos no último seguimento: ao sair do corredor e adentrar na sala de jantar, Godofredo encontra outra mulher. Desanimado, acha que essa mulher é a sua quarta esposa. Entretanto, a moça, chamando-o por João de Deus, explica-lhe que os dois ainda são noivos e que o casamento será na próxima semana. Em seguida, senta-se à mesa com ela e passa a pensar em sua vida, sentindo que seus crimes se repetirão incessantemente.

Após esse breve panorama, partimos para um detalhamento geométrico do conto. Ao dividirmos a narrativa em três blocos, traçamos um perfil circular em cada parte e, mais além, na narrativa como um todo. Assim, temos: 1) o círculo principal, que engloba toda a diegese (isto é, funciona como estrutura básica do conto), caracterizado nos seguintes passos: encontrar 
uma mulher - ir para casa - (re)encontrar uma mulher - cometer um assassinato; 2) o círculo secundário, que dá conta do primeiro bloco, ou seja: o protagonista encontra a segunda esposa no restaurante; depois vai para casa; reencontra Geralda e a mata; e, por fim, retorna ao ponto de partida do círculo, ao restaurante; 3) o círculo terciário, formado por duas semicircunferências que, juntas, formam um círculo completo: a) primeira semicircunferência: Godofredo encontra a primeira esposa no restaurante; volta para casa; b) segunda semicircunferência: encontra no corredor a terceira mulher e a mata; e o 4) círculo quaternário, também composto por duas semicircunferências: c) terceira semicircunferência: Godofredo encontra a sua noiva na sala; d) quarta semicircunferência: formada através de uma linha tracejada pelo leitor, que supõe que a história irá se repetir, completando o ciclo com a morte da noiva quando se tornar esposa.

Para que esse mapeamento circular fique ainda mais claro, recorremos à figura:

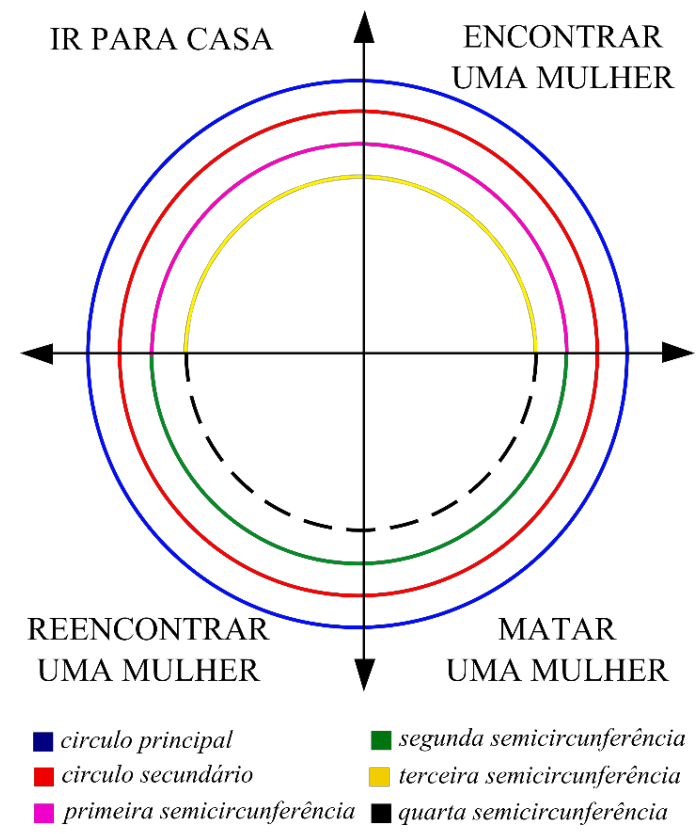

Figura 1: Mapa circular de "Os três nomes de Godofredo". Fonte: nossa elaboração.

Além dessa circularidade das ações, podemos apontar os deslocamentos circulares do protagonista, que se transfere do restaurante para a casa e da casa para o restaurante todo o tempo. Em certo sentido, essa circulação limitada entre os dois espaços e a repetição, praticamente mecânica, de ações nos remete à obra $A$ invenção de Morel (1968), de Adolfo Bioy Casares, na qual vários personagens têm suas imagens gravadas numa máquina e, através dessa gravação, estão a repetir seus atos e deslocamentos ad infinitum. Ademais, segundo 
Carlos Nejar, “o cosmos muriliano é arbitrário, move-se dentro de suas evidências irrefutáveis, circularmente, como em Dante" (NEJAR, 2011, p. 750). Em outros termos, de modo semelhante aos círculos infernais da Divina Comédia (2005), de Dante Alighieri, na medida em que trocamos de circunferência no conto de Rubião, os círculos parecem afunilarem-se, isto é, as ações ocorrem mais rapidamente. ${ }^{4}$

\subsection{Um Lado: tempo}

Além dos espaços circulares e das ações que se repetem num ciclo perpétuo, podemos apontar o tempo como outro fator relevante para referendar a estrutura circunferencial da narrativa. Em "Os três nomes de Godofredo", os tempos ${ }^{5}$ se alternam num rito circular, no qual o narrador autodiegético está "condenado a tentar decifrar o enigma de sua própria condição" (SCHWARTZ, 1981, p. 15). Para que esse mecanismo se torne mais nítido, vamos ao trecho inicial da história:

Ora, aconteceu que vislumbrei uma ruga na sua testa. De uma data que não poderia precisar, todos os dias, no almoço e ao jantar, ela sentava-se à minha frente, na mesa, onde por quinze anos fui o único e invariável ocupante.

Quando, uma tarde, por acaso, me certifiquei de sua presença, considerei o fato perfeitamente natural. A mesa não me pertencia por nenhum direito e, ademais, minha vizinha nada fazia que me importunasse. Nunca me dirigia a palavra e o seu comportamento durante as refeições era alheio a qualquer ruído ou atitude que despertasse atenção. (RUBIÃO, 1947, p. 143)

$\mathrm{Na}$ passagem acima, temos o momento em que Godofredo começar a narrar sua maldição. É a partir da "ruga" que enxerga no rosto da companheira de refeições que sua trágica história entra em andamento, ou seja, passa a ser contada. Desse modo, já é possível indicar que o momento da narrativa se dá anteriormente a todos os eventos narrados pelo protagonista, isto é, ao contar sua história, Godofredo já vivenciou tudo aquilo que conta. Nessa senda, todos os atos narrados estão marcados pelos verbos no passado porque já ocorreram (“aconteceu”,

\footnotetext{
${ }^{4}$ Em um primeiro momento, cogitamos adotar o conceito matemático de conjunto para a demonstração da estrutura circular deste conto. Entretanto, ao empregarmos esse conceito, partiríamos, obrigatoriamente, do círculo menor para o maior, ou seja, em vez de haver um afunilamento dos círculos (conforme encontramos nesta narrativa curta), teríamos um alargamento das circunferências. Por esse motivo, preferimos o modelo de círculos concêntricos de Dante Alighieri (2005), mais adequado ao texto literário analisado.

${ }^{5}$ Quando nos referimos aos tempos da narrativa, estamos abordando, apenas, a variação temporal dos eventos que são narrados. No que diz respeito ao tempo das epígrafes (presentes tanto no grupo narrativo "IV - Condenados", de $O$ ex-mágico, como também em versões posteriores do conto analisado), realizaremos uma discussão detalhada em tópico posterior.
} 
"vislumbrei”, "sentava-se" "fui", “certifiquei”, “considerei” etc.). Após perceber essa imperfeição na moça, Godofredo se incomoda com a presença dela e, por isso, a interroga:

— Você é minha convidada, não?

- Claro! E não o precisava ser para estar aqui.

- Como? indaguei estupefato.

- Ora, desde quando se tornou obrigatório ao marido convidar a esposa para jantar e almoçar?

— Mas você é minha mulher?

- Sim, sua segunda esposa. E preciso dizer-lhe que a primeira era loura e você a matou, num acesso de ciúmes?

— Não, não é necessário. (Ficara bastante abalado em saber que era casado e não queria que me criassem o remorso de um assassinato, do qual nenhuma lembrança tinha) (RUBIÃO, 1947, p. 145).

Nesse fragmento, há uma mudança temporal: para relatar ou resumir as ações ocorridas, o narrador emprega quase todos os verbos no passado; quando dialoga com as mulheres, elege o tempo presente, principalmente nos verbos de estado (como no caso de "é"), recurso que produz um efeito dinâmico à conversa. É importante salientar, ainda, a onisciência de Geralda (que se repetirá em outras duas mulheres): enquanto Godofredo está perdido e nada sabe sobre si mesmo, sua segunda esposa detém o conhecimento sobre o passado dele (assassinato da primeira esposa), sobre o presente (pois assegura que ambos estão casados) e, provavelmente, sobre o futuro, que a levará para o mesmo fim que a primeira esposa.

Esse poder profético é ainda mais claro no surgimento da primeira esposa na narrativa. ${ }^{6}$ Logo depois de matar a segunda esposa, Godofredo se dirige ao restaurante. Ao chegar no recinto, encontra sua primeira esposa. Em outras palavras, o evento insólito do conto ocorre nesse instante: em vez de primeiro aparecer a morte da primeira esposa para, em seguida, acontecer o assassinato da segunda, Rubião transgride a concepção cronológica do tempo, isto é, na ordem que se apresenta na narrativa, a primeira surge após a segunda, mesmo já estando morta.

Sendo assim, o aparecimento da primeira esposa na diegese instaura um tempo mítico e circular, que se converte em um tempo infinito, além de tornar Joana diferente das outras, pois lhe dá poderes especiais (visto que ela é a única que é representada numa ordem temporal transgressora) e, por esse motivo, torna-se portadora do anúncio da maldição, ao proclamar que “não lhe virá o esquecimento". Ademais, no diálogo com Joana, existem verbos que são

\footnotetext{
${ }^{6}$ Os trechos relacionados ao surgimento da primeira esposa estão transcritos no tópico seguinte. Para um entendimento mais detalhado, vale a consulta.
} 
empregados nos três tempos, o que indica a fusão temporal gerada pela presença anacrônica dessa figura na diegese.

Seguindo nesse fluxo, associamos o recurso de combinação de vários tempos num tempo sem fim, empregado por Rubião, com a indagação do narrador de Vicente Barbieri em "Dos veces el mismo rostro", quando questiona se "[...]¿es verdad aquello de que presente y futuro son simultáneos? ¿Algún encuentro en el vasto tiempo, que más tarde se repite ante nuestros ojos asombrados de no poder recordar?” (BARBIERI, 1960, p. 45). Dito de outro modo, a questão apresentada no conto argentino se materializa em "Os três nomes de Godofredo" com a sutil diferença de que ao presente e ao futuro também se acrescenta o passado; no mais, Godofredo (que, para a primeira esposa se chama Robério), vive o tempo todo a assombrar-se por não poder recordar suas relações amorosas e boa parte dos crimes cometidos em seu passado sombrio.

Então, ao fugir da primeira esposa depois de ouvir suas predições, Robério retorna a sua casa, conforme veremos a seguir:

E não perdi tempo em indagações inúteis por que fora parar no portão de casa. Fechei-o com o cadeado e tranquei, por dentro, a porta da entrada. Por um segundo, pensei no cadáver de Geralda e tive vontade de recuar. Demasiado tarde. Diante de mim estava uma mulher parecidíssima com as minhas esposas. Tinha os cabelos alourados, como Joana e se diferençava das duas por ter as sobrancelhas muito arqueadas e uma ametista no dedo anular. (RUBIÃO, 1947, p. 153)

Como Joana prognosticou, Godofredo não se esqueceu das mortes anteriores ao chegar em casa. Mesmo cismado, resolveu entrar e, de repente, surge outra mulher em sua frente. Sem muita reflexão, ele a estrangula, assim como fez com as outras. Em adição a isso, podemos destacar o retorno dos tempos verbais ao passado, ou seja, após a turbulência do evento insólito e da confusão de tempos, o curso narrativo aparenta retornar à normalidade, mas com uma leve mudança: mesmo não estando plenamente consciente dos motivos que o levam a cometer assassinatos, Godofredo agora sabe que esta é a sua sina e não poderá fugir dela, por mais que tente.

Em seguida, ele depara com a quarta mulher:

Vencido, sem coragem de intentar qualquer resistência, aproximei-me: Naturalmente você é a minha quarta esposa.

— Não, João de Deus. Ainda somos noivos. O casamento será na próxima semana - respondeu, convidando-me para sentar.

Aquiesci ao convite, certo de que não teria mais forças para enfrentar meus inimigos. (Que inimigos seriam eles?) (RUBIÃO, 1947, p. 153-154). 
Nesse último encontro, Godofredo (que volta a ser nomeado por João de Deus, vocativo que aponta para o reinício do ciclo) já está sem forças, pois tem certeza que seu destino está arruinado. Apesar dessa mulher lhe explicar que os dois ainda não se casaram, de nada adianta, porque João de Deus acredita que irá matá-la futuramente. Em acréscimo, percebemos o uso dos verbos no passado, indicando o fracasso das tentativas de escapar de suas desgraças (nesse caminho, são atos apodrecidos e infrutíferos), e do futuro trazido pela voz da noiva, que atrai a previsão de um devir funesto e estéril para Godofredo.

Em resumo, temos: o tempo dos eventos narrados (que é anterior ao tempo em que se realiza a narração), que desemboca no uso de verbos no passado quando se faz um relato ou resumo dos fatos; os verbos no presente no momento do diálogo com a segunda esposa; os verbos que oscilam entre presente, passado e futuro na conversa com a primeira esposa; o retorno ao passado ao se falar da terceira mulher; e a variação entre passado e futuro na conversação com a noiva. Logo, essa mobilidade dos tempos se constitui num constante ir e vir, através de um caminhar em círculos, até formar uma esfera de gelo unívoca, onde passado e futuro se fundem em um presente mecânico ${ }^{7}$, que está sempre a se repetir e a rodar, e no qual Godofredo está fadado a matar a mesma mulher eternamente. ${ }^{8}$

\section{Circunferência retabular}

Ao examinarmos, com cuidado, o conto do nosso corpus, notamos que a narrativa se assemelhava à estrutura de alguns retábulos medievais. Mais precisamente, o elo que une essas duas instâncias artísticas consiste na retratação de distintos momentos num único plano, o que causa a impressão, mesmo que momentânea, no espectador/leitor de que todas as ações ocorrem simultaneamente. No entanto, entre as duas artes existe uma sutil diferença: enquanto o pintor tem a possibilidade de apresentar, de fato, diversos eventos numa única tela de modo a fazer com que o observador tenha a visualização de todo o quadro numa única vista, o escritor

\footnotetext{
${ }^{7}$ Essa noção de tempo se assemelha à de Marco Aurélio, quando argumenta que "quem viu o presente viu todas as coisas: as que aconteceram no passado insondável, as que acontecerão no futuro" (apud BORGES, 1999, p. 437).

${ }^{8}$ Embora sejam quatro mulheres diferentes, todas possuem aparência semelhante e vivenciam o mesmo fim trágico, o que nos leva a interpretá-las como a mesma mulher. Essa compreensão é reforçada pelos vocativos relativos a Godofredo, que se dividem em três (João de Deus, Robério e Godofredo), mesma quantidade de nomes relacionados às mulheres.
} 
necessita esboçar a noção de simultaneidade de forma sucessiva ${ }^{9}$, isto é, o leitor só percebe a coexistência dos fatos narrados à medida em que segue a sequência das frases. ${ }^{10}$

Em acréscimo, apesar de boa parte desses retábulos não apresentarem em sua montagem um formato circular, o movimento do olho de quem as vê, certamente, fará um percurso que circundará as imagens. Em outras palavras, quando estamos contemplando uma obra de arte retabular (para fixarmos um exemplo, trouxemos abaixo $O$ retábulo de Isenheim ${ }^{11}$, de Matthias Grünewald) as retinas flutuam de um painel para o outro através de um rito circular, almejando uma compreensão da obra como um todo unívoco, ou seja, é necessário que contrastemos os painéis (e, por extensão, os tempos correspondentes a cada painel) para que, em seguida, alcancemos uma compreensão de unidade.

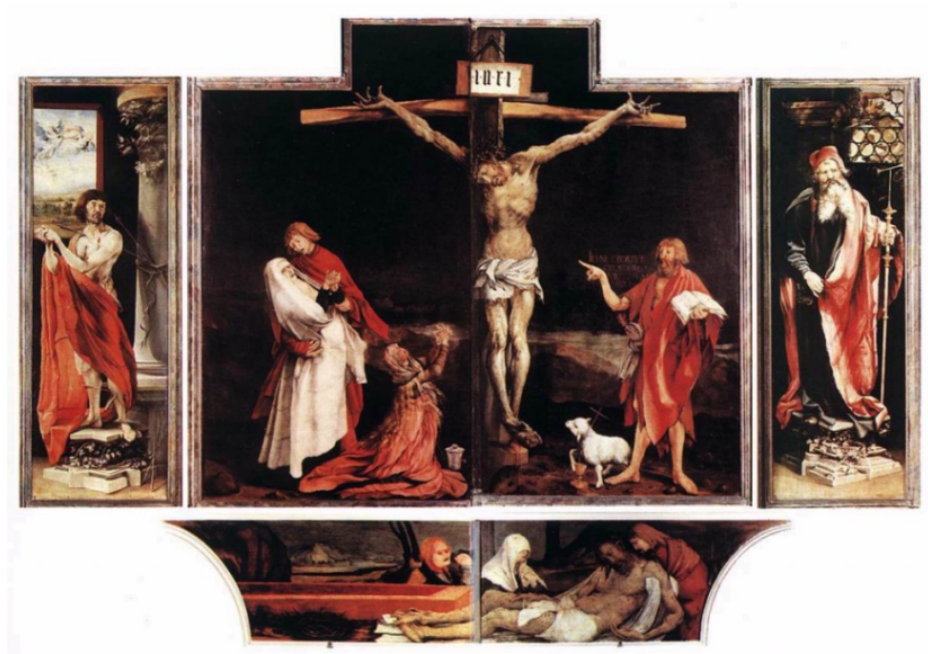

Figura 2: $O$ retábulo de Isenhein, de Matthias Grünewald.

Fonte: www.quasesertao.com/2012/03/o-altar-de-grunewald-exaltacao.html.

\footnotetext{
${ }^{9}$ Lessing, em seu Laocoonte ou sobre as fronteiras da poesia e da pintura (1998), discute acerca das semelhanças e das discrepâncias entre o pintor e o poeta. No capítulo XIV, ao comparar o historiógrafo com o poeta, o autor explica que "existem fatos pintáveis e não pintáveis e tanto o historiógrafo pode narrar os mais pintáveis igualmente não pictoricamente, como o poeta é capaz de expor os menos pintáveis de modo pictórico" (LESSING, 1998, p. 185). Dessa maneira, concluímos que apesar da simultaneidade não se configurar como um recurso favorável à escritura poética, o autor habilidoso poderá se apropriar desse conceito e aproximá-lo da técnica de pintura à sua maneira, como ocorre com Rubião.

${ }^{10}$ Essa "dificuldade" para narrar imagens presenciadas de forma simultânea também está presente no conto "El Aleph", de Jorge Luis Borges: "Lo que vieron mis ojos fue simultáneo: lo que transcribiré, sucesivo, porque el lenguaje lo es" (BORGES, 2000, p. 133).

11 “No centro do Retábulo de Isenheim há um 'relicário' de madeira entalhada mostrando Santo Antônio. Ele é rodeado por uma série de portas com dobradiças, que podem ser dispostas para mostrar a Anunciação, a Natividade e a Ressureição. Estas cenas são muito diferentes, no colorido e na atmosfera, da Crucifixão, que é a imagem pintada nas portas externas" (CUMMING, 1996, p. 35). A partir dessa breve explicação, temos ideia da variedade das cenas presentes numa mesma obra.
} 
Nessa senda, mais além da semelhança entre o conto e os retábulos, encontramos, também, um certo parentesco entre a narrativa abordada e a via sacra ${ }^{12}$. De forma mais precisa, descobrimos a relação próxima entre as estações da via crúcis e a numeração do conto dentro do livro que a compõe, assim como o avizinhamento do nome das estações com o que se passa nas narrativas. Essa "sincronicidade", conceito de Jung descrito por seus discípulos em $O$ homem e seus símbolos (2008), não é algo que deve ser desprezado, isto é, a "coincidência significativa" descoberta nesta análise não ocorre de forma gratuita, por mais que não haja uma relação de causa e efeito entre os fatos. Ainda segundo Jung, existem certos eventos que sentem necessidade de se agrupar a outros; desse modo, interpretamos a aproximação dos contos com a via sacra como um desses casos.

Portanto, reparamos que o conto "Os três nomes de Godofredo" se trata do número doze dos quinze contos presentes no livro $O$ ex-mágico. Esse número está associado a $12^{\text {a }}$ Estação, na qual temos a figura de Jesus morto na cruz. Esse sinal fúnebre é interessante porque se torna símbolo de todas as mortes ocorridas na diegese e, mais além, funciona como pré-figuração da ressureição das mulheres que acontecerá de forma repetitiva. Ademais, o livro em si comporta quinze contos, número que corresponde à $15^{\mathrm{a}}$ Estação, cuja representação dá conta da ressurreição de Cristo $^{13}$. Dito de outro modo, o número doze aponta para a morte de Cristo, bem como para a das mulheres na narrativa de Rubião, e carrega a promessa de ressureição desses mortos; enquanto o número quinze cumpre a promessa de ressureição de Cristo e sinaliza a ressureição das mulheres (que também são a mesma mulher), que sempre voltarão para atormentar Godofredo, gerando, assim, um ciclo perpétuo.

Para que isso fique mais claro, trazemos o trecho no qual a primeira esposa "volta à vida" e aparece para Godofredo:

Acabava de dar com a fisionomia de uma mulher que, não fossem os cabelos louros, juraria ser minha esposa. A sua semelhança com Geralda me assombrava. Os mesmos lábios, nariz, olhos e a mesma maneira de comer. Refeito do choque que me causara a sua presença, quis saber quem era.

- É você, não é Geralda? (Perguntei mais para iniciar uma conversa do que para receber uma resposta afirmativa. Geralda tinha os cabelos castanhos e um dente de ouro).

\footnotetext{
${ }^{12}$ Ademais, podemos salientar que o uso de epígrafes bíblicas por Murilo Rubião patenteia seu vínculo literário com a religião católica.

${ }^{13}$ Em boa parte das fontes pesquisadas sobre a via sacra, encontramos referências, apenas, a catorze estações e não a quinze. Por outro lado, também levantamos fontes que dão conta de quinze (como o site da Paróquia Sagrada Família Taquara e o site da editora Paulinas). Diante desse impasse, preferimos a segunda opção por melhor atender ao nosso corpus.
} 
— Não, respondeu ela. Sou a sua primeira mulher. A segunda, que, de fato, se chamava Geralda, você a matou, faz poucos instantes.

— Sim, já sei. Matei-a num acesso de ciúmes... acrescentei zombeteiramente.

- Tinha que ser assim. O ciúme sempre lhe corroeu a alma, meu pobre Robério. (RUBIÃO, 1947, p. 151-152)

Após estrangular a segunda esposa, Godofredo se encaminha ao restaurante. Assim que entra no local, percebe a presença de uma mulher parecidíssima com a que acabara de matar. Em seguida, ele inicia "uma conversa" com essa recém-chegada, no intuito de conhecê-la melhor. Logo depois, essa mulher se apresenta como a primeira esposa de Robério (que, cronologicamente, já se encontra morta), demonstrando, assim, ter conhecimento sobre o último assassinato cometido pelo protagonista. Como falado no tópico anterior, Joana aparece na fábula para quebrar com a linearidade temporal da narrativa e instaurar um tempo mítico/circular. Nesse caminho, preferimos interpretar Joana não como um fantasma ou alucinação, mas como alguém que retorna à vida com a missão de revelar o futuro (em certo sentido, de forma análoga a Cristo).

Além disso, semelhante ao que faz o protagonista de "O cavalo perdido", de Felisberto Hernández, para o qual “(...) não the é permitido recordar seu passado: ele tem de fazer o milagre de recordar na direção do futuro" (HERNÁNDEZ, 2006, p. 47), Joana relembra um fato que é posterior a sua existência, consistindo, assim, num paradoxo: ou ela realiza uma premonição do passado (isto é, ela sabe de um evento que, linearmente, ocorreu depois de sua morte, mas que, ao mesmo tempo, findou antes de sua aparição concreta na narrativa) ou ela executa uma lembrança do futuro (na medida em que rememora um fato anterior a sua aparição na diegese, mas que também se desenrolou após seu homicídio).

Todos esses argumentos se sustentam pelo caráter profético empregado por Joana, visto que ela possui tanto informações sobre o passado de Godofredo como sobre o futuro, conforme veremos a seguir: "Tentei recuperar a calma, a fim de desfazer um possível erro de minha interlocutora. / - Tudo já passou, Joana. Chamo-me Godofredo. / — Engana-se, Robério. Não lhe virá o esquecimento.” (RUBIÃO, 1947, p. 152). Sendo assim, Joana carrega em si os três tempos: foi o passado de Godofredo; o diálogo com ele se aproveita dos verbos no presente; e ela lança uma praga para o futuro, ao garantir que ele não se esquecerá das suas ações. Em suma: Joana é quem comporta o recurso da fusão de tempos num único tempo; sem ela, o tempo circular na narrativa seria inexistente.

Diante disso, reiteramos a proposta de "tudo ao mesmo tempo, e agora" empregada por Rubião nesse conto, que pode ser equiparada a uma pintura que contenha a hagiografia de algum santo (como o Retábulo de São Jorge, de Bernat Martorell). Em outros termos, da mesma forma 
que um pintor tem a capacidade de resumir os momentos mais importantes da vida de um ser santificado num único plano, Rubião também o faz, mas, obviamente, adaptando ao seu projeto estético. Dessa maneira, o autor mineiro não se interessa por retratar as fases da vida do protagonista responsáveis por sua canonização, mas sim por eternizar uma maldição, aprisionála num espaço-tempo circular (o qual se afasta de uma concepção euclidiana) rumo ao infinito.

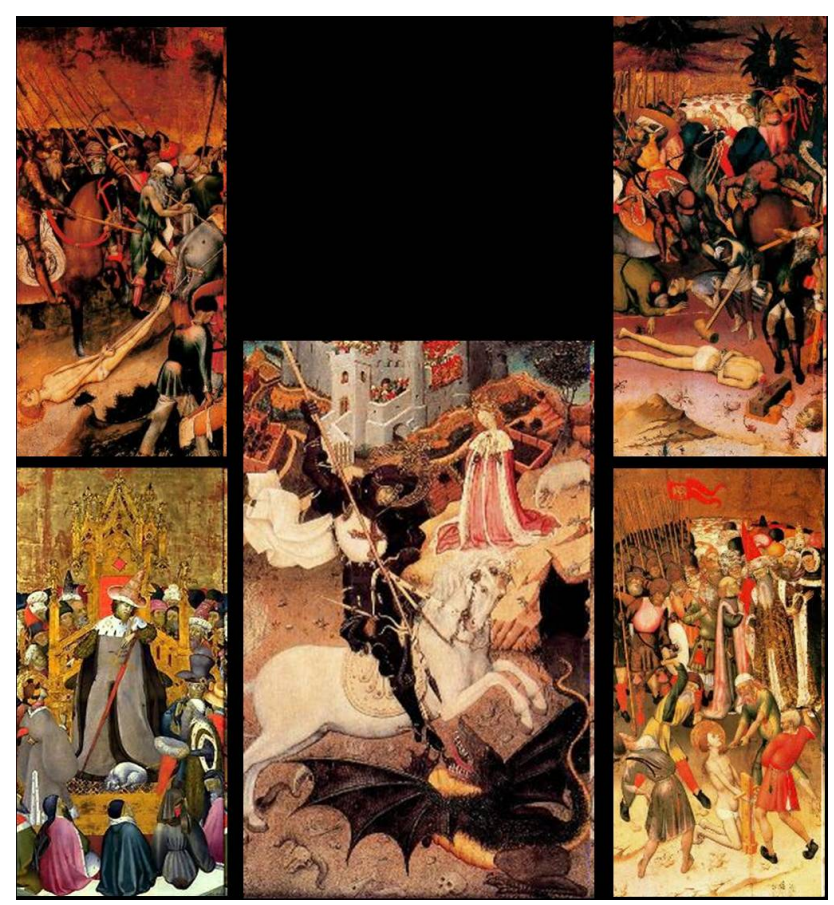

Figura 3: Retábulo de São Jorge, de Bernat Martorell.

Fonte: pt.wikipedia.org/wiki/Bernat_Martorell\#/media/File:Martorell-retaule_jordi.jpg.

\section{Círculo escrito, circunscrito}

Além da sua materialização na estrutura espaço-temporal das narrativas, assim como no enredo, o círculo também se faz presente na linguagem de Murilo Rubião. Nesse sentido, este tópico se encarrega de discutir as alusões feitas a essa figura geométrica no conto analisado.

Em primeiro lugar, podemos destacar a variação circular na nomeação de um personagem. No momento que inaugura a narrativa, isto é, quando o protagonista está no restaurante com a sua segunda esposa, esta utiliza o vocativo João de Deus; após o assassinato de Geralda e o encontro com Joana, a primeira esposa, o homem afirma chamar-se Godofredo, enquanto Joana o nomeia por Robério; quando ele retorna a sua casa, mata a terceira mulher e depois encontra sua noiva, esta o invoca por João de Deus e com isso voltamos ao ponto de 
partida do círculo. ${ }^{14}$ Nessa senda, retornar ao primeiro nome do protagonista indica um regresso à origem de seu flagelo e, por extensão, um reinício do ciclo narrativo, que perdurará indefinidamente. ${ }^{15}$

Outro momento em que ocorre a presença de um indício da figura do círculo está no trecho a seguir:

Eu agora falava muito e gostava de vê-la comer, aos bocadinhos, mastigando demoradamente os alimentos. Às vezes, Geralda interrompia os meus discursos com uma observação ingênua:

- Se a Terra roda, por que não ficamos tontos?

Longe de me impacientar, explicava-lhe uma porção de cousas graves. Ela arregalava os olhos e me lisonjeava com um exagerado elogio à minha cultura (RUBIÃO, 1947, p. 150).

Após vários dias em contato com a sua segunda esposa, Godofredo muda o seu comportamento em relação a ela, ou seja, nos primeiros momentos ele não sabia como agir e agora já interage com Geralda de forma mais dinâmica, dando liberdade para que ela faça diversas perguntas. Então, desembocamos na referência ao círculo, compreendida, aqui, através de duas significações. A primeira, mais superficial, relaciona-se ao movimento de rotação da Terra, isto é, ao perguntar sobre as voltas que o planeta dá, Geralda se refere ao movimento de rotação e, nesse caminho, podemos associar esse giro em torno do mesmo eixo ao caminhar da narrativa, que se move, mas, por outro lado, não sai do lugar. A outra possível interpretação está em contrapor o que foi dito por Geralda com a primeira conclusão: o fato de a Terra rodar e as pessoas que estão nela não ficarem tontas com essa ação é inverso ao que ocorre no conto, ou seja, enquanto a narrativa é lida (e com essa leitura, entra em movimento, roda), tanto o

\footnotetext{
${ }^{14}$ Essa variação é ressaltada se nos determos aos significados dos nomes. De acordo com Pându \& Pându (1999), João significa "Deus é gracioso", enquanto Godofredo quer dizer “paz de Deus". O nome Robério consiste numa fusão de dois nomes: Roberto ("brilhante na glória") e Rogério ("afamado na lança"). Sendo assim, ao mudar de nome, o personagem oscila entre duas condições: a sacra e a mundana. Essa oscilação funciona como uma pequena amostra do projeto estético de Murilo Rubião, que dialoga com as duas esferas: é mundano por ser literatura, isto é, algo feito por homens; e é sagrado por rivalizar (ou seja, disputar espaço) com as escrituras sagradas.

${ }^{15}$ Essa ciranda de nomes também é encontrada nos personagens femininos. São três mulheres nomeadas: Joana (feminino de João, que significa "Deus é gracioso"), Geralda (feminino de Geraldo, que significa “forte na lança”) e Isabel (derivado de Elisabete, “consagrada a Deus"). Nesse caminho, as mulheres podem realizar um duplo movimento (que reflete a dupla condição delas), a depender do observador: 1) o mesmo percurso de Godofredo, se tomarmos o curso cronológico (a primeira esposa é Joana, que aponta para o sacro; a segunda é Geralda, que deságua no mundano; e, a terceira, Isabel, que retoma o teor sagrado); ou 2) a ordem da narrativa (Geralda é a primeira mulher que surge na diegese, sinaliza o caráter mundano; depois vem Joana, que insere o sagrado; e Isabel, que mantém a atmosfera do sacro), trajetória oposta à executada pelo protagonista.
} 
protagonista, quanto os leitores ficam desnorteados com essa rotação, perdem a noção de equilíbrio.

Já a última menção que alude ao círculo também se relaciona com Geralda, no instante em que Godofredo se prepara para enforcá-la: "Uma tarde, olhei muito para os lados, sem nenhuma intenção aparente. Enxerguei uma corda dependurada num prego, na sala de jantar. Agarrei-a e disse para Geralda, que se conservava abstrata a tudo que se desenrolava em redor: — Ela lhe servirá de colar" (RUBIÃO, 1947, p. 150-151). Depois de saciada a curiosidade inicial, o casal entra numa rotina entediante até findarem sem trocar quaisquer palavras entre si. Esse martírio de ambos é encerrado no momento em que Godofredo visualiza uma corda e pensa em adorná-la, funestamente, no pescoço da mulher. Sendo assim, destacamos o percurso circular feito pela corda (pois, para servir "de colar", a corda tem que circundar o pescoço), que caracteriza o círculo como elemento responsável por asfixiar os personagens femininos. Isso será confirmado, ainda, pela terceira mulher morta, visto que, para alguém ser estrangulado, é necessário que outra pessoa faça um movimento circular com as mãos em volta do pescoço da vítima.

\section{Circuito em série: a relação texto e epígrafe}

Do Gênesis vem a última lição deste trabalho: "no suor do teu rosto comerás o teu pão, até que tornes à terra, porque dela foste tomado; porquanto és pó, e ao pó tornarás" (BÍBLIA, III, 19). Melhor dizendo, eis a profecia decifrada: da epígrafe viemos e à epígrafe retornaremos; que caiam mil círculos à nossa esquerda e dez mil à nossa direita: sempre seremos atingidos.

Nessa senda, o número final desta explanação reafirma o trajeto circular: ao lermos o texto a partir de sua epígrafe, fazemos uma determinada leitura, isto é, a epígrafe (e, por extensão, a obra de onde foi retirada) interfere diretamente na leitura do texto que a segue; por outro lado, ao término da leitura, costumamos voltar ao ponto de partida (a epígrafe), ressignificando-o, ou seja, a leitura do texto influencia a releitura da epígrafe e, mais além, do contexto no qual a epígrafe se insere.

Então, fica claro que essa releitura da epígrafe confere uma interpretação distinta da primeira leitura. Desse modo, entramos num circuito circular ininterrupto: a leitura da epígrafe demanda a leitura do texto; a leitura do texto requer a releitura da epígrafe; a releitura da epígrafe anseia pela releitura do texto e assim sucessivamente. 
Como se viu nos tópicos anteriores, o andamento circular da narrativa analisada se dá várias maneiras: seja pelo espaço, seja pela ação, seja pelo tempo, seja pela representação de variados eventos em um mesmo plano, seja pela alusão ao círculo. Para Schwartz, o uroboro (a figura circular de uma cobra que morde o próprio rabo) das narrativas rubianas é gerado pelas ações do protagonista, pois "o herói é vítima de um processo que ele mesmo, sem querer, desencadeia, e o qual não pode mais dominar" (SCHWARTZ, 1981, p. 38).

Essa postura se afasta da perspectiva adotada nesta investigação, que aponta a epígrafe como elemento instaurador da maldição circular dos personagens. Dito de outro modo, o protagonista não é responsável por desencadear a sua desgraça ao dar um passo em falso, mas sim o seu destino circula, já traçado antes mesmo de se iniciar o texto e anunciado, profeticamente, pela voz epigráfica. De certa forma, essa ideia se aproxima dos pensamentos de Jung, quando afirma que

O homem gosta de acreditar-se senhor da sua alma. Mas enquanto for incapaz de controlar os seus humores e emoções, ou de tornar-se consciente das inúmeras maneiras secretas pelas quais os fatores inconscientes se insinuam nos seus projetos e decisões, certamente não é seu próprio dono (JUNG, 2008, p. 83).

Em outros termos, o protagonista do conto apreciado se julga senhor do seu destino, acreditando que é dono dos seus atos e da repercussão destes. No entanto, existem elementos desconhecidos pelo personagem (neste caso, a voz premonitória da epígrafe), que regem a sua existência ficcional e, nesse curso, sobrepõem-se às vontades do indivíduo. Dessa maneira, concluímos que não importa o que Godofredo faça, não haverá saída: nunca conseguirá escapar da sina circular que lhe foi imposta.

Para dar seguimento à análise, recuperamos a ideia de conjunto matemático, no que diz respeito à ligação hierárquica existente entre cada conjunto numérico. Em outras palavras, observaremos o "conjunto epigráfico" menor e a sua relação com o "conjunto epigráfico" que o envolve. Por outro lado, para facilitar o entendimento de nossas explanações, exploraremos um percurso inverso ao empregado nas aulas de matemática (isto é, começaremos pelo conjunto maior para depois nos determos nos menores), tendo em vista uma melhor adaptação às necessidades do nosso objeto. E, de modo mais objetivo, para além da relação entre a epígrafe do livro inteiro e a epígrafe do capítulo em que o conto está inserido, serão discutidas, também, as epígrafes que acompanham a narrativa curta em edições posteriores - mais especificamente, nas obras Os dragões e outros contos (1965) e A casa do girassol vermelho (1974). 
Logo nas primeiras páginas de $O$ ex-mágico, encontramos a seguinte epígrafe, retirada do livro de Gênesis, referente à obra como um todo: "E quando eu tiver coberto o céu de nuvens, nelas aparecerá o meu arco.” (BÍBLIA apud RUBIÃO, 1947, p. 5). Esse versículo já prenuncia o destino circular dos personagens: no momento em que o "céu" das narrativas estiver nublado, ou melhor, nos instantes de maior adversidade para os protagonistas, veremos o arco da voz profética (neste caso, os mecanismos circulares empregados nos textos).

Além disso, podemos indicar outro movimento circular percebido nessa epígrafe (e, por extensão, nas outras empregadas por Rubião): a constante alteração de sentido proveniente da relação epígrafe-texto literário e da relação texto literário-epígrafe-obra de onde a epígrafe foi retirada.

Dito de outro modo, no texto bíblico, esse arco marca a aliança de Deus com Noé e com todos os outros seres que sobreviveram ao dilúvio, indicando que não haverá outra catástrofe de mesma natureza no planeta; tendo esse conhecimento, o leitor o transporta para o livro de Rubião e, antes de iniciar a leitura, cria uma expectativa de que essa voz premonitória também estabeleça uma aliança positiva com os personagens da narrativa; à medida em que lê os contos, percebe que o acordo anunciado é desastroso; ao finalizar a leitura, tende a reler a epígrafe e ressignificá-la de acordo com a leitura dos textos rubianos, modificando, assim, a sua interpretação da epígrafe e da Bíblia.

De modo resumido, assinalamos que a compreensão da aliança efetuada por Deus com os mortais passa a ser influenciada pela aliança de Murilo Rubião com seus personagens e, nessa ótica, recebe tanto uma perspectiva de rigor geométrico, como também uma negativa. Em contrapartida, os textos de Rubião também ganham novos significados nesse processo constante de leitura e de releitura. Nas palavras de Jorge Schwartz, ao fazer uso de epígrafes bíblicas “é como se o autor reafirmasse continuamente que, embora fantásticos, seus temas são tão antigos e tão atuais como a própria Bíblia” (SCHWARTZ, 2006, p. 101).

Após a apreciação da epígrafe do livro, passamos para a epígrafe do capítulo em que o conto "Os três nomes de Godofredo" está inserido (obtida do livro de Ageu): "Vós semeastes muito, e recolhestes pouco; comestes, e não ficastes fartos; bebestes, e não matastes a sede; cobristes-vos, e não ficastes quentes; e o que ajuntou muitos ganhos, meteu-os num saco roto.” (BÍBLIA apud RUBIÃO, 1947, p. 115). Submissa a uma epígrafe circular e claustrofóbica (a do livro todo), esta epígrafe se encarrega de apresentar a circularidade das ações estéreis dos protagonistas dos contos do capítulo "IV - Condenados". Como já dito anteriormente, não importa o que os personagens façam, nunca conseguirão escapar de maldição circular proferida pelas epígrafes. Dessa maneira, concluímos que a ciranda de ações apresentada na epígrafe 
representa a nulidade dos atos dos protagonistas do capítulo: semear e não colher; comer e não saciar a fome; beber e não saciar a sede; ajuntar ganhos e guardá-los em um saco furado.

Já epígrafe que acompanha a narrativa curta no livro Os dragões e outros contos (1963), retirada de Isaías, recupera as anteriores através da quebra de expectativa e das ações que deságuam na vacuidade: "Multiplicaste a gente, não aumentaste a alegria." (BÍBLIA apud RUBIÃO, 1963, p. 115). Em outras palavras, apesar de em algumas traduções da Bíblia o versículo se apresentar sem o advérbio de negação, Rubião opta por ele para destacar a falta de correspondência entre os atos, ou seja, mesmo que haja aproximação com a fecundidade, a ação finda infértil, representando, então, o destino trágico de seus personagens.

A última epígrafe que se associa ao conto "Os três nomes de Godofredo", obtida do livro de Jó, está localizada no livro A casa do girassol vermelho (1978): “As sombras cobrem a sua sombra, os salgueiros da torrente o rodearão.” (BÍBLIA apud RUBIÃO, 1978, p. 27). Ao observarmos, rapidamente, a sua construção, as alusões ao círculo se sobressaem, seja no momento em que as sombras circundam o interlocutor da voz profética (no caso do conto, o protagonista), seja ao mencionar a circunferência que será formada pelos salgueiros (que, em relação à narrativa, são as mulheres que cercam a vida de Godofredo).

De modo mais profundo, outra relação circular a ser realçada neste ponto de investigação é a comparação de Godofredo a Jó. Dito de outro modo, ambos os protagonistas se assemelham, diferenciando-se, quase exclusivamente, pelo seu fim: ambos possuem um destino que foge ao seu controle; ambos perdem elementos essenciais de suas vidas (Jó: as riquezas e a família; Godofredo: a memória); no entanto, Jó finda sendo restituído pela sua fé ${ }^{16}$, enquanto Godofredo, que não tem a quem apelar, acaba desacreditado.

Nesse curso, a narrativa de Jó é circular devido ao movimento de fortuna e de ruína do protagonista (no início do livro está em fortuna; passa pela ruína; e retorna à fortuna de forma mais sólida), à medida que o conto de Rubião se apropria da circularidade na constante reaparição das mulheres e no repetir incessante dos atos de Godofredo, pois o personagem se encontra arruinado desde o princípio da diegese.

Desse modo, reiteramos a interferência e a influência de uma leitura sobre a outra, isto é, a leitura do livro de Jó altera o entendimento da narrativa rubiana (à medida em que se espera uma restituição a Godofredo que nunca virá), enquanto a leitura de Rubião também modifica a

\footnotetext{
${ }^{16}$ Apesar de ser restituído, Jó não recebe, de fato, as pessoas e os objetos que perdeu. Sua restituição diz respeito ao quantitativo, isto é, o servo de Deus recupera o número de filhos e até ultrapassa o que tinha antes, administra muito mais riquezas do que no início de sua tormenta etc.
} 
leitura do livro de Jó, visto que este se encontra dentro de um círculo fechado, o qual não pode sair por escolha própria, sendo totalmente dependente das vontades de um ser superior para lhe salvar dos tormentos. ${ }^{17}$

Por isso, notamos a semelhança da relação das epígrafes e das narrativas com o funcionamento de um circuito em série de resistores, no qual o fim de um resistor está conectado com o início do outro. Em outras palavras, é isso o que ocorre na relação epígrafe-narrativa: o fim de uma se liga ao início da outra, formando um círculo (ou circuito) fechado, que não será interrompido enquanto as condições se mantiverem as mesmas, ou seja, enquanto houver leitor que libere a corrente elétrica da leitura ${ }^{18}$.

\section{Considerações finais}

Como demonstrado ao longo desta exposição, o círculo está presente em diversas faces do objeto literário (e também geométrico) aqui analisado. No primeiro momento, focalizamos as discussões nos campos do espaço, da ação e do tempo. Nesse caminho, em "Os três nomes de Godofredo", encontramos relações circulares na repetição estéril dos atos do protagonista e no constante retorno de mulheres (que foram ou serão assassinadas) à vida de Godofredo, o que alude a uma esfera de tempo congelada.

O tópico seguinte foi dedicado à associação das narrativas com os retábulos medievais, os quais apresentam a representação de variados eventos num único plano, o que, em certo sentido, dialoga com concepção de tempo mítico e circular. Nesse viés, demos destaque à primeira esposa de Godofredo, que funciona como o ponto de fusão dos tempos passado, presente e futuro.

$\mathrm{Na}$ terceira parte apreciativa, buscamos abordar as menções relacionadas à figura do círculo. Foram analisados os trechos que davam conta do movimento de rotação da Terra (que, inversamente à narrativa de Rubião, não causa tontura aos humanos) e da utilização da corda

\footnotetext{
${ }^{17}$ Para encerrar as análises das epígrafes de Rubião, vale destacar outro traço circular: a constante alteração das epígrafes. Para além da relação de hierarquia geométrica de uma sobre a outra e da constante troca de sentidos de uma com a outra, o próprio ato de modificar a epígrafe ao longo de novas edições do conto evidencia uma "circularidade do processo criativo" (SCHWARTZ, 1981, p. 88).

${ }^{18} \mathrm{O}$ conceito de circuito fechado envolve a presença de um ou mais componentes interligados, que se ordenam não necessariamente numa estrutura circular, mas sim numa ordem fechada, estrita. Contudo, essa lógica de organização pode ser entendida por nós como um círculo deformado, fustigado por rasuras na sua circunferência. Essa compreensão também se aproxima da escrita rubiana, na medida em que seu texto é abundante em lacunas para que o leitor as preencha a partir do seu repertório.
} 
como um colar (o que deságua na interpretação do círculo como um elemento causador de asfixia nos personagens). Em adição a isso, salientamos a circularidade dos nomes do protagonista e das mulheres que o circundam, seja no que diz respeito à constante mudança de nomes até retornar ao nome inicial, seja na oscilação de significados (que partem do sagrado, passam pelo mundano, para, ao final, regressar ao sacro).

$\mathrm{Na}$ seção das epígrafes, ressaltamos o movimento circular da relação epígrafe-texto literário e vice-versa, visto que a leitura da epígrafe muda a leitura do texto literário que a segue e que a leitura do texto literário transforma a compreensão da epígrafe e, mais além, da obra de que esta foi retirada. Nesse sentido, abordamos as epígrafes do livro $O$ ex-mágico, do capítulo "IV - Condenados" e do conto "Os três nomes de Godofredo" nas três versões publicadas. Ainda é válido destacar que também observamos as citações ao círculo nessas epígrafes, como também a relação de hierarquia circular entre elas com base na noção matemática de conjuntos numéricos.

Em adição a isso, segundo Jung (2008), o círculo deve ser interpretado como símbolo da totalidade. Sendo assim, indicamos que Murilo Rubião aproveita-se desse símbolo em sua obra para deformar (e, logo, refutar) a ideia de totalidade, à medida em que modifica o rigor circular da narrativa para deixá-la aberta à entrada de seu público. Nas palavras dele:

— Acredito que essa [minha] elaboração [literária] não funcione numa novela ou num romance, mas no conto você deve usar o mínimo de frases, o mínimo de palavras, para que o próprio leitor descubra e amplie o conteúdo do conto. - Durante certo tempo, essa minha preocupação em nunca terminar um conto, deixando sempre as conclusões pare o leitor, foi inconsciente. Com o amadurecimento isso foi se tornando consciente. (RUBIÃO, 1974, p. 4)

Então, diante de todo o exposto, podemos indicar que o círculo em Murilo Rubião denuncia a circularidade de seu fazer literário. Nas palavras de Schwartz: "a escritura muriliana surge como um mecanismo rotativo, onde as palavras constituem a condenação à qual o Autor se submete: um contínuo re-fazer do próprio material" (SCHWARTZ, 1981, p. 93). Ou seja, chegamos à conclusão de que o círculo funciona como elemento norteador do projeto literário do autor investigado, seja por causa das motivações anteriores aos textos (o constante reescrever dos textos de Rubião, isto é, o texto literário, mesmo publicado, não tem fim, é sempre processo), seja pelo emprego da figura geométrica ao longo das narrativas (de forma expressa ou subentendida).

Portanto, para finalizar o trabalho, retomamos Ezra Pound, quando afirma que "pouco importa, no mundo contemporâneo, por onde se inicia o exame de um assunto, desde que se 
persista até voltar outra vez ao ponto de partida" (POUND, 2013, p. 36). E, após essa volta completa, outra vez chegamos à estaca zero, cujo retorno anuncia a existência de outro homem, que, neste exato instante, está em casa e, preocupado com sua origem, desvenda a obra Incêndios. Ao final da leitura, ele, certamente, estará em cinzas. Então, ainda desnorteado, buscará consolo (talvez impiedoso) na Bíblia (ou, mais precisamente, no livro de Jó) e perceberá no círculo a origem do seu autor preferido. Em seguida, encantado com a descoberta, usará a epígrafe bíblica como mote e passará a escrever, exaustivamente, este texto, até que outro venha e lhe suceda, depois um outro, depois outro, outros.

\section{Referências}

ALIGHIERI, D. A divina comédia. Introdução, tradução e notas de Vasco Graça Moura. Edição bilíngue. São Paulo: Editora Landmark, 2005.

BARBIERI, V. Dos veces el mismo rostro. In: CÓCARO, N. (Org.). Cuentos fantásticos argentinos. Buenos Aires: Emecé, 1960. p. 43-45.

BÍBLIA online. Disponível em: $<$ https://www.bibliaonline.com.br/acf/gn/3>. Acesso em: 15 abr. 2017.

BORGES, J. L. El Aleph. In: . El Aleph. Barcelona: Biblioteca de la Literatura Universal, 2000. p. 123-136.

. Obras completas de Jorge Luis Borges. São Paulo: Globo, 1999. v. 1.

CASARES, A. B. La invención de Morel. Buenos Aires: Emecé, 1968.

CORTÁZAR, J. Alguns aspectos do conto. In: . Valise de cronópio. Tradução Davi Arriguci Jr. e João Alexandre Barbosa. São Paulo: Perspectiva, 2006. p. 147-163.

CUMMING, R. Para entender a Arte. Tradução Isa Maria Lando. São Paulo: Ática, 1996.

HERNÁNDEZ, F. O cavalo perdido. In: . O cavalo perdido e outras histórias. Seleção, tradução e posfácio David Arrigucci Jr. São Paulo: Cosac Naify, 2006. p. 17-65.

JUNG, C. G. et al. O homem e seus símbolos. Tradução de Maria Lúcia Pinho. 5. ed. Rio de Janeiro: Nova Fronteira, 2008.

LESSING, G. E. Laocoonte ou sobre as fronteiras da Pintura e da Poesia. Introdução, tradução e notas Márcio Seligmann-Silva. São Paulo: Iluminuras,1998.

MOUAWAD, W. Incêndios. Tradução de Angela Leite Lopes. Rio de Janeiro: Cobogó, 2013.

NEJAR, C. Os mágicos da ficção. In: . História da Literatura Brasileira: da carta de Caminha aos contemporâneos. São Paulo: Leya, 2011. p. 747-795. 
PANDU, P.; PANDU, A. Que nome darei ao meu filho?: influência do nome, data do santo, diminutivos, etimologia, significado, variantes, história. 23. ed. Rio de Janeiro: Ediouro, 1999.

PARÓQUIA Sagrada Família Taquara. Disponível em $<$ http://www.sagradafamiliataquara.com.br/index.php/catequese/48-as-15-estacoes-da-via-sacra $>$. Acesso em: 24 maio 2017.

PAULINAS: a comunicação a serviço da vida. Disponível em: $<$ https://www.paulinas.org.br/loja/via-sacra-15-estacoes>. Acesso em 24 maio 2017.

POUND, E. ABC da Literatura. Tradução de José Paulo Paes e de Augusto de Campos. 12. ed. São Paulo: Cultrix, 2013.

QUASE-SER-TÃO. O altar de Grünewald: exaltação religiosa. Disponível em: <http:// www.quasesertao.com/2012/03/o-altar-de-grunewald-exaltacao.html>. Acesso em 14 maio 2017.

RUBIÃO, M. O ex-mágico: contos. Rio de Janeiro: Editora Universal, 1947.

RUBIÃO, M. Os dragões e outros contos. Belo Horizonte: Movimento-Perspectiva, 1965.

RUBIÃO, M. Murilo Rubião. In: . O pirotécnico Zacarias. São Paulo: Ática, 1974. p. 3-5.

RUBIÃO, M. A casa do girassol vermelho. São Paulo: Ática, 1978.

SCHWARTZ, J. Murilo Rubião: a poética do uroboro. São Paulo: Ática, 1981.

SCHWARTZ, J. Murilo Rubião: um clássico do conto fantástico. In: RUBIÃO, M. O pirotécnico Zacarias e outros contos. São Paulo: Companhia das Letras, 2006. p. 101-110.

WIKIPÉDIA. Retábulo de São Jorge (reconstrução). Disponível em: $<$ https://pt.wikipedia.org/wiki/Bernat_Martorell\#/media/File:Martorell-retaule_jordi.jpg>. Acesso em: 12 maio 2017. 


\title{
Os insólitos corpos de Murilo Rubião: uma leitura de "Bárbara" e "As unhas" The unusual bodies of Murilo Rubião: a reading of "Bárbara" and "As unhas"
}

\author{
Bruno Silva de Oliveira* \\ Jamille da Silva Santos** \\ Andréia Alencar de Oliveira Iguma***
}

\begin{abstract}
RESUMO: O presente artigo tem como objetivo analisar a construção dos corpos em dois contos do escritor Murilo Rubião: "Bárbara" (1974) e "As unhas" (1994), uma vez que é por meio das manifestações insólitas de cunho biológico presentes nesses contos que podemos, tantas vezes, questionar as imposições sociais que circunscrevem nossa sociedade a partir da imposição de "corpos" padrões. A perspectiva de análise ganha relevância a partir da noção de corpo do filósofo Michel Foucault (2010), no que tange toda a construção social e psicológica. Nesse prisma, entendemos que as alterações corporais tecidas nos contos supracitados contribuem significativamente para pensar a ordem e desordem social a partir de padrões impostos que excluem e homogeneízam o que é heterogêneo. E é justamente nesse ponto que as manifestações insólitas ganham relevância, uma vez que por meio do irreal questionamos o real.
\end{abstract}

\begin{abstract}
This article aims to analyze the construction of the bodies in two short stories by Murilo Rubião, "Bárbara" (1974) and "As unhas" (1994). It builds on the notion that through the unusual manifestations of biological nature present in these stories we can often question the social impositions that circumscribe our society based on the imposition of standard "bodies." The perspective of analysis gains relevance from the notion of body by philosopher Michel Foucault (2010), when it comes to its social and psychological value. In this perspective, we understand the corporal changes woven in these stories contribute significantly to thinking about the social order and disorder from imposed standards that exclude and homogenize what is heterogeneous. And it is at this point that unusual manifestations gain relevance, since it is through the unreal that we question the real.
\end{abstract}

PALAVRAS-CHAVE: Contos. Corpo. Insólito. KEYWORDS: Short stories. Body. Unusual.

\footnotetext{
* Professor efetivo da área de Letras do Instituto Federal Goiano - Campus Iporá. Aluno do Doutorado do Programa de Pós-graduação em Estudos Literários da Universidade Federal de Uberlândia (UFU). Membro do Grupo de Pesquisa em Espacialidades Artísticas (GPEA). Mestre em Estudos da Linguagem pela Universidade Federal de Goiás/ Regional Catalão (UFG/RC). Licenciado em Letras - Língua Portuguesa/ Língua Inglesa e suas respectivas literaturas pela Universidade Estadual de Goiás - Câmpus de Iporá. Bolsista do Programa de Incentivo à Qualificação (PIQ) do IF Goiano.

** Aluna regular do Programa de Pós-Graduação em Estudos Literários - nível Doutorado da Universidade Federal de Uberlândia (UFU). Mestre em Linguística pela Universidade Estadual do Sudoeste da Bahia (UESB). Licenciada em Letras Vernáculas pela Universidade Estadual do Sudoeste da Bahia (UESB). Membro do grupo de pesquisa em Espacialidades Artísticas (GPEA/ CNPq) e do grupo de pesquisa: Estudos sobre o Discurso e o corpo (grudcorpo/CNPq).

*** Doutoranda em Estudos Literários pela Universidade Federal de Uberlândia - UFU; Mestre em Letras (Literatura e Práticas Culturais) pela Universidade Federal da Grande Dourados - UFGD (2012); Graduada em Letras também pela UFGD (2007). Atua principalmente nos seguintes temas: críticas literárias, literatura e ensino, vertentes do insólito e literatura juvenil. Faz parte do comitê do PROLER na cidade de Dourados - MS. Professora do curso de Letras do Centro Universitário da Grande Dourados - UNIGRAN e colunista para o LITERATUDO.
} 


\section{Palavras iniciais}

Murilo Rubião tem um parco número de contos publicados se comparado a consagrados autores brasileiros, tais como Monteiro Lobato, Machado de Assis, Guimarães Rosa, entre outros. Entretanto, seus trinta e três contos publicados em vida, possuem grande relevância dentro da produção entendida como literatura fantástica escrita no país, tanto que a crítica especializada lhe atribuiu o título de "pai" da literatura fantástica em solo brasileiro.

Exigente consigo, o autor escrevia e reescrevia seus textos diversas vezes até chegar ao ponto de considerá-los perfeitos, incluía e/ou suprimia trechos, essas “alterações, contudo, não modificam profundamente o conto [...], e valem menos como material de pesquisa do que como signo da reescritura" (CARNEIRO, 2013, p. 85).

Ademais, alguns dos seus contos sofreram alterações mesmo após estarem publicados, o que foi impossível de ser feito com "As unhas", publicado postumamente em 1994, na seção "Memória" do Suplemento Literário de Minas Gerais (nov. 1994, n. 1, p. 4-5), após aproximadamente três anos de seu falecimento, por Vera Lúcia Andrade, que, naquele período, era diretora do Centro de Estudos Literários da Faculdade de Letras da Universidade Federal de Minas Gerais (UFMG) e Ana Cristina Pimenta da Costa Val, que era bolsista de iniciação científica na referida instituição. O conto foi resgatado do espólio deixado pelo autor e doado pela família em 1992 à Faculdade de Letras da UFMG, estando hoje no Acervo da Biblioteca Universitária da instituição, juntamente com outros.

Em 2013, a narrativa volta a ser lembrado ao ser republicada no livro Murilo Rubião 20 anos depois de sua morte pela Editora da Universidade do Estado do Rio de Janeiro (EdUERJ). O referido livro é fruto de um evento realizado em novembro de 2011 em homenagem aos 20 anos de falecimento do escritor. Assim, "As unhas" entra para o rol de textos publicados de Murilo Rubião totalizando trinta e quatro narrativas.

A escrita de Rubião não se limitava a uma temática, porém, ao ler sua produção, é possível validar a forte presença do corpo, o que nos instigou a analisar os dois contos supracitados por meio dessa ótica, uma vez que são corpos que se modificam e se transformam de formas inimagináveis. Nesse prisma, trazemos em matéria de ilustração o conto "Alfredo" que narra a história de um metamorfo que se modifica inúmeras vezes chegando até a ter a composição de um verbo, o resolver; outro exemplo se faz presente em "Teleco o coelhinho", pois há um ser que se metamorfoseia cujo o sonho é ser gente, a personagem que dá título à narrativa se transforma incessantemente na tentativa de realizar o seu sonho, mas só consegue tornar-se uma criança raquítica quando morre; em "Bárbara", lemos a respeito de uma mulher 
cujo corpo cresce desmedidamente na medida em que sonha; e em "As unhas", a protagonista passa anos de sua vida lutando com suas unhas que não param de crescer de forma inexplicável e constante.

Ao recuperar a presença do corpo em tais narrativas, justificamos que a escrita deste artigo terá como mote analisar a forte presença do corpo em: "Bárbara" e "As unhas", uma vez que é por meio dessas manifestações insólitas de cunho biológico que podemos, tantas vezes, questionar as imposições sociais que circunscrevem nossa sociedade a partir da imposição de “corpos" padrões, e essa questão vai além do que é projetado dentro da dicotomia belo e feio, mas alça voos e ganha ainda mais relevância dentro dos corpos abjetos excluídos socialmente. Validamos que a atenção maior será dada ao conto "As unhas", em função de sobre ele ter incido menos análises até o momento por parte da crítica literária.

\section{Corpos incomensuráveis}

A metamorfose é "um recurso muito frequente para a instauração do insólito" (GAMAKHALIL, 2013, p. 46), principalmente, em uma sociedade líquida em que os corpos, pensamentos e atitudes se modificam com tamanha fluidez. Infelizmente, vivemos a era das plásticas e da busca por um corpo perfeito instituído socialmente, com isso, um comércio gigantesco é movimentado em torno de cirurgias, academias, clínicas de estéticas e outros recursos que acarretam diretamente mudanças físicas e psicológicas que são "aceitas", uma vez que não ocasionam estranhamento.

Todavia, a literatura contribui com a reflexão acerca das marcas sociais de cada tempo, assim questionamos: por que os corpos transmutados na literatura provocam tamanho estranhamento no leitor e, tantas vezes, os referidos corpos transformados na sociedade, não?

Nesse prisma, buscamos validar possíveis respostas a esse questionamento. Assim, nosso objetivo será pensar corpos apresentados na literatura como uma projeção de acontecimentos no mundo entendido como real; para isso, adentramos em dois contos de Murilo Rubião: "Bárbara" e "As unhas", narrativas cujo mote, como já evidenciado, possuem as transformações corporais em um universo prosaico projetado pela ficção.

Bárbara, do conto homônimo publicado em 1974, aparentemente é uma mulher mimada por seu marido, que busca realizar todos os desejos dela, logo é colocada em um lugar de estranhamento quando seus pedidos se tornam alimento não só para alma, mas para seu corpo físico, como podemos observar logo no início da narrativa: "Bárbara gostava somente de pedir. 
Pedia e engordava" (RUBIÃO, 2016, p. 22). Desse modo, Bárbara se alimenta dos seus desejos, engordando cada vez mais.

No início, o seu cônjuge não estranhava tal fato, já que a personagem é descrita como magra e seus desejos poderiam fazer com que ganhasse um pouco mais de peso, o que remete, mais uma vez, a uma sociedade do controle sobre o corpo, a qual determina o que pode ou não ser visto e feito e como deve ser um corpo belo. Nesse sentido, Michel Foucault, em seu livro Os Anormais (2010), afirma que a norma, isto é, os manuais de conduta, serve como regulação das possibilidades existentes. Assim, o corpo de Bárbara, no excerto acima, não se enquadra em um corpo belo. "Bárbara era menina franzina e não fazia mal que adquirisse formas mais amplas" (RUBIÃO, 2016, p. 23), o que faz com que seu esposo se ampare em justificativas para realizar alguns de seus desejos, contribuindo para que ela possa ganhar um pouco mais de peso, e assim, se enquadrar nas imposições sociais.

Já em "As unhas", o lugar do controle da sociedade está marcado por uma aparente organização. A protagonista, Henrique, é obcecada com os cuidados referentes ao seu corpo, o que o leva a investir horas do seu dia se arrumando. "Alisava os cabelos, irrepreensivelmente penteados, corrigia a gravata branca, já colocada no lugar exato onde deveria ficar" (RUBIÃO, 2013, p. 126).

No que tange as duas narrativas em destaque é possível validar que em ambas há uma obsessão com o corpo. Em "Bárbara", o narrador, que é o marido da protagonista, enfatiza, no início do conto, as características corporais da esposa, justificando o fato de ela poder engordar um pouco; e depois, quando o corpo dela se avoluma e engorda, assinala sua insatisfação pelo fato dela continuar fora do padrão, afinal, antes era magra de mais, e agora obesa. No segundo conto, o narrador põe o leitor diante de uma personagem que tem fixação por organização, marcado pelo termo "irrepreensivelmente" que assinala o lugar de que não há nada para ser ajustado ou repreendido; todavia, Henrique continua em frente ao espelho se corrigindo e exercendo sobre seu corpo um controle. Ele não para de ajeitar seus cabelos, que já se encontram perfeitos e de arrumar a gravata, que está no devido lugar.

Nesse prisma, Revel (2005) valida que a forma de controle que se exerce sobre si e sobre o corpo é determinada por vários poderes laterais, os quais funcionam como uma forma de normatização, que tem como função determinar o que é certo e o que é errado, ou seja, no caso dos corpos, o que seria feio ou belo, permitido ou proibido, instaurando um estatuto, um padrão legalizado.

Entretanto, observamos que todo o controle é rompido logo no decorrer da narrativa, Bárbara que, no início, era descrita como alguém que podia engordar, logo excede o padrão, 
uma vez que engorda "incessantemente” (RUBIÃO, 2016, p. 23); já Henrique que, no início da narrativa, se encontra perfeito, passa a ter cada detalhe de seu corpo fora daquilo que é milimetricamente pensado como padrão, o imprevisto para o desgoverno de Henrique foram suas unhas, que iniciam um processo desregulado de crescimento, aparentemente sem nenhuma explicação e, com isso, se instala a anormalidade.

Foucault (2010) afirma que o não funcionamento de leis em uma instância social gera uma punição no corpo, estabelecendo um estatuto jurídico-biológico, na medida em que existem regulações sociais que devem ser cumpridas e o seu não cumprimento gera uma punição de âmbito biológico. Nesse sentido, o sujeito, que rompe as leis estabelecidas, é reduzido a um enquadramento de uma anomalia. Isso o colocaria no lugar de sujeito externo a essas leis, diferente de todo o corpo social que as segue, atribuindo a ele um caráter de monstro, o que é para Foucault (2010, p. 47) "em sua existência mesma e em sua forma, não apenas uma violação das leis da sociedade, mas uma violação das leis da natureza". Isso gera um "registro duplo, infração às leis em sua instância mesma. O campo do aparecimento do monstro é, portanto, um domínio que podemos dizer “jurídico-biológico"” (FOUCAULT, 2010, p. 47).

A forma de transformação do corpo tanto de Bárbara como de Henrique se dá no âmbito de uma ruptura biológica, tendo em vista que o corpo de Bárbara cresce desenfreadamente por meio de desejos e as unhas de Henrique crescem sem uma única justificativa. Porém, é possível perceber um elo em ambas as narrativas: o pecado capital funcionando como mote para instauração do insólito: a gula, no primeiro e o orgulho, no segundo, que estão ligados a um terceiro - a vaidade.

A gula, pecado atribuído à alimentação, mais especificamente ao exagero em relação ao alimento, tem lugar de destaque no conto "Bárbara", por meio dos inúmeros desejos, tais como desejar o mundo e alimentar-se dele, contudo quanto mais deseja, mais desejos ela tem, logo engorda cada vez mais. Já Henrique tem como principal pecado o orgulho, que está ligado à vaidade, uma vez que ao se sentir superior aos outros, sua vaidade é representada ficcionalmente por meio do seu contato com o espelho, em sua busca incessante pela perfeição como também de vaidade em relação ao outro. Quando planeja a forma de causar maior impacto no baile, a personagem tem tanta certeza de ser alguém superior, que acredita que ficando em casa todos sentiriam a sua falta, como se observa na citação abaixo:

Ao voltar-se para o espelho, a fim de colocar a flor na lapela, estava decidido. Em vez de entrar tarde no clube, ou acompanhado de uma dama desconhecida, como pensara antes, resolvera ficar em casa. O efeito seria maior. Todos comentariam a sua ausência e Petúnia, esperando-o a noite toda, sem dançar, 
os olhos fixos na(s) porta(s), imaginaria mil coisas, sem chegar uma conclusão lógica do que teria acontecido. (RUBIÃO, 2013, p. 126)

A partir da leitura do excerto podemos perceber que a personagem se coloca no centro de todas as ações; projetando-se como a figura mais importante, ele acredita ser o convidado principal, a peça fundamental que faria o evento funcionar, e assim decide não ir à cerimônia, pois todos se questionariam a respeito de sua ausência e que sua aparente namorada, a viúva Petúnia, passaria a noite inteira à sua espera.

Em nossas análises, gula e vaidade são o estopim para as metamorfoses sofridas pelas personagens de Rubião. Bárbara não para de engordar chegando ao ponto de "vários homens, dando as mãos, uns aos outros, não conseguiriam abraçá-lo o seu corpo" (RUBIÃO, 2016, p. 27). Em "As unhas", Henrique tenta de todas as formas controlar o crescimento de suas unhas e não consegue; para manter sua rotina saía "sempre munido de uma tesourinha, tinha o cuidado de não se demorar com as pessoas" (RUBIÃO, 2013, p. 128). Dessa forma, o corpo passa a exercer um controle sobre a vida das personagens. A primeira, em função do excesso de gordura, não conseguia locomover seu corpo, e o segundo pelo fato de ter que manter suas unhas sempre cortadas, não podendo ficar muito tempo longe de casa e ter que sempre andar com um instrumento para o corte.

Como afirma Henrique, no conto, ele possuía "preocupação com a anomalia" (RUBIÃO, 2013, p. 128). Foucault (2010) pontua que, por meio de uma composição de traços corporais, vê-se funcionando o lugar do monstro, ou seja, do anormal. Para Foucault (2010, p. 48), o lugar de "referência do monstro humano é a lei", é, portanto, na ruptura com as leis que temos a criação do monstro.

O monstro é o modelo poderoso, a forma desenvolvida pelos jogos da natureza de todas as irregularidades possíveis. Neste sentido, pode-se dizer que o monstro é o grande modelo de todos os pequenos desvios. É o princípio de inteligibilidade de todas as formas, circulando - sob a forma de moeda miúda da anomalia. (COURTINE, 2009, p. 256-257)

Nesse prisma, quando as personagens de Rubião são dominadas por seus pecados, vêse incidir em seus corpos uma forma de punição. Criam-se monstros pelo alargamento do corpo, ou pelo crescimento demasiado das unhas; nesse sentido, o anormal se instala dentro da narrativa. Foucault (2008) observa que as transgressões de determinadas normas de condutas devem gerar uma punição que evidencie a norma e sirva de exemplo de como não se portar. 
Nessa esteira de pensamento, ao tomarmos a literatura como projeção ficcional do mundo e das leis deste é possível verificarmos nos corpos uma punição que serve ao leitor de exemplo do que "não deve ser feito".

No que tange à escrita de Murilo Rubião, destacamos que o autor trabalha com corpos hiperbólicos, que crescem de forma exagerada, que transcendem o normal e o cotidiano; são estruturas espaciais que evidenciam a face insólita das narrativas e, por meio deles, o leitor pode perceber a transgressão à norma e ver emergir em si um estranhamento diante dos fatos narrados. Por exemplo, a inquietação se Bárbara irá explodir e quando isso ocorrerá, se Henrique terá as unhas tão grandes quanto às orelhas do protagonista do conto "O homem cuja orelha cresceu", de Ignácio de Loyola Brandão. Seria ele descoberto e suas unhas iriam incomodar tanto ao ponto de ele ter o mesmo fim que o desafortunado protagonista de Brandão? Pois bem, são muitos os questionamentos, assim, nos atentaremos no momento seguinte ao conto “As unhas", uma vez que, como anunciado no início deste texto, por ser uma publicação póstuma, possui poucas análises.

\section{Henrique, o homem cujas unhas não param de crescer?}

A narrativa se inicia com um dado espacial, o protagonista, Henrique Canavarro, estava em frente a um espelho se preparando para ir a uma festa. Damos destaque ao cenário, uma vez que o espelho é um objeto recorrente nas narrativas fantásticas, sendo um elemento que desestabiliza as personagens que se postam diante dele; esse objeto enigmático é um elemento central em narrativas de Machado de Assis e José J. Veiga, pois revela nuances e deformidades físicas e/ou psicológicas das personagens que se contemplam diante dele.

Henrique se admira em demasia no espelho, o que leva a uma leitura capaz de identificar seu egocentrismo e o narcisismo, uma vez que "estava excessivamente concentrado nos preparativos e nada teria força para desviar-lhe a atenção" (RUBIÃO, 2013, p. 125); o fato é reforçado em virtude de mirar-se "demoradamente, antes de colocar a casaca, satisfeito com o físico atlético e o rosto ainda jovem" (RUBIÃO, 2013, p. 125). Um dado interessante percebido nesses fragmentos é que ele admite ser atlético e jovem a partir de sua contemplação diante do espelho. Logo, o espelho e a veneração do corpo, que causa o assombro a sua última conquista, a viúva Petúnia, e a inveja dos outros homens, são os elementos centrais do conto sob os quais os demais acontecimentos orbitam. 
O narrador relata que a todo momento o protagonista Henrique se volta para o espelho, seja para contemplar-se ou arrumar-se para a festa, validando seu amor próprio. Ele crê ser o centro das atenções nos espaços que atravessa, que suas entradas são acontecimentos dentro dos eventos que participa, pois, na festa para qual estava se arrumando, deseja causar um efeito maior do que provoca normalmente, e, por isso, cogita não ir ao compromisso, dado que sua ausência geraria mais comentários e sentimentos diversos do que a sua presença. $\mathrm{O}$ egocentrismo de Henrique é reafirmado no trecho "ao deitar-se, pensava ainda em Petúnia; no desespero dela que pouco lhe importava" (RUBIÃO, 2013, p. 126), haja vista estar mais preocupado em como ela materializaria o desespero pela sua falta do que os sentimentos. Já o narcisismo do senhor Canavarro é realçado pelo narrador nos primeiros parágrafos, pois faz-se menção à personagem diante do espelho a se contemplar quatro vezes no início do conto e uma última no desfecho.

Em consonância, a tese de doutoramento intitulada "A narrativa insólita em Murilo Rubião: um fantástico inquietante e moderno" (2016) defendida na Universidade Federal do Rio de Janeiro (UFRJ), o autor Vanderney Lopes da Gama disserta sobre a relação da personagem com o espelho, pois a partir do objeto o sujeito enxerga uma realidade outra, que não é real, visto que enxerga uma realidade ideal, sem defeito ou mácula. Entendemos aqui o espelho como um espaço da atopia, uma junção do espaço da utopia e da heterotopia, onde real e irreal convergem, a pessoa se vê em um lugar em que ela não está "entretanto o espelho existe realmente e tem um efeito retroativo, pois por meio dele a pessoa se descobre ausente no lugar onde está" (GAMA-KHALIL, 2012, p. 36). Partindo dos princípios da física, o espelho projeta, a partir da refração da luz, uma imagem invertida e virtual do objeto posto em frente a ele; por exemplo, se a palavra ROMA for posta diante do espelho, ele não refletirá ROMA, mas AMOR. Certamente, o espelho não reflete uma imagem simetricamente perfeita, mas uma simetria bilateral, em que um lado é idêntico ao outro apesar de estar invertido a partir do eixo. Para Gama (2016), a personagem está vendo o reverso da realidade, ou seja, sua imagem invertida, ao contrário, logo ele vê aquilo que queria ser ou já fora, "possivelmente, era uma imagem dos tempos em que ele se enquadrava dentro daquelas descrições, guardada inconscientemente em sua memória" (GAMA, 2016, p. 110).

Em consonância, Cordeiro (2007, p. 46) defende que "o efeito de ressonância construído por estes jogos de simetria (invertida) não visa tanto uma representação bifacetada da realidade quanto uma negação da própria realidade: o outro lado do espelho não reflecte um outro real mas o próprio processo de acusação do real". 
A irrupção do acontecimento insólito não se dá diante do espelho, mas ao sair de sua frente. Quando a personagem se deita para dormir e deixa de contemplar-se diante do objeto é que fato o insólito ocorre. Henrique repara que as suas unhas haviam crescido subitamente, visto que naquela tarde a manicura as tinha cortado, porém não deu importância ao ocorrido, cortou-as novamente e deitou-se.

Dormiu algum tempo. Duas horas depois acordou, sentido algo estranho nas mãos. Tinha a impressão de que alguma coisa se lhe acrescentará às unhas e lhe arranhava as mãos. Acendeu a luz. As unhas tinham crescido novamente. Mais espantado ficou. Cortou-as de novo, perplexo com o que lhe estava acontecendo: como, em tão breve espaço de tempo, elas podiam crescer tanto? Alcançavam a cinco centímetros! (RUBIÃO, 2013, p. 127)

O autor mineiro, na tentativa de convalidar o acontecimento narrado, faz marcações temporais e espaciais: em duas horas, as unhas tinham crescido cinco centímetros. Esses acontecimentos vêm para suscitar o estranhamento no leitor, pois as unhas das mãos crescem em torno de três milímetros por mês, principalmente durante o dia, provavelmente em virtude da rápida circulação sanguínea nesse período. As unhas são lâminas de queratina feitas a partir das células que morrem debaixo da pele dos dedos das mãos e dos pés, tendo a mesma função que as garras têm nos demais animais; no entanto, tornaram-se finas e passaram apenas a proteger a última falange dos dedos.

Henrique tenta racionalizar o acontecimento insólito “devia ser uma doença” (RUBIÃO, 2013 , p. 127) e que na tarde seguinte procuraria um médico. Ele percebe o fato como algo estranho, as unhas não crescem de forma normal. Com medo de que lhe fosse atribuído uma moléstia segregatória, como o câncer ou a lepra, e de que esse boato se espalhasse pela cidade, decide não ir ao médico, pois acreditava que o fato não tinha gravidade, então cortou as unhas durante todo o dia.

Como passou o dia cortando as unhas, percebeu que o crescimento obedecia a uma constante invariável, durante os primeiros noventa minutos elas cresciam um pouco e que nos trinta minutos seguintes cresciam exponencialmente. Mediante tal descoberta, Henrique volta a frequentar os amigos e as reuniões, ciente que não podia se demorar mais do que uma hora e trinta minutos, mas, caso acontecesse algum imprevisto, sempre trazia no bolso uma tesourinha de unhas para extirpar as pontas que ganhavam vida extraordinariamente. A preocupação com as unhas tirava-lhe a paz, o medo de que descobrissem sua anormalidade era evidente em sua face e em seu comportamento, causando preocupação nos amigos e em Petúnia. Em uma ocasião, quando estava perto da pretendente, as unhas de Henrique cresceram fora do ciclo 
"normal" e ela soltou um grito horrorizada, como ele não conseguiu explicar o fato a sua noiva saiu correndo, para nunca mais procurá-la.

Após o ocorrido, redobrara as precauções para não ser descoberto, cortava as unhas compulsivamente. Esse comportamento estranho fez com que ele se isolasse em casa, "precisava curar-se. Por isso, encomendou todos os livros de medicina relativos a unhas e suas doenças. Em nenhum deles, porém, descobriu algo parecido com o mal que sofria” (RUBIÃO, 2013, p. 128), isso porque o fenômeno insólito "é sempre sugerido como exceção, como um acontecimento incomum, pois do contrário se converteria em algo normal e não seria tomado como uma transgressão, como uma ameaça" (ROAS, 2014, p. 114). Henrique não conseguiu explicações nos livros, então se correspondia com especialistas no exterior, mas nenhuma resposta foi positiva, ninguém conhecia a sua moléstia.

Os criados começaram a perceber e a comentar entre eles a obsessão do patrão com as unhas, cortando-as constantemente. Logo, Henrique se viu obrigado a demitir todos os funcionários e a ver sua casa ser mergulhada no caos e abandono, pois não contratou ninguém para substituí-los. Passou a não realizar as atividades domésticas, a não fazer a barba e a não cuidar de sua aparência, estando mais preocupado em contar as unhas para que elas não crescessem como trepadeiras.

O leitor depara novamente com a vaidade do senhor Canavarro, ele tinha um consolo momentâneo quando lembrava o efeito de curiosidade e de ausência na sociedade causado por sua reclusão, porém tal sentimento logo se esvaía quando lembrava que Petúnia presenciou o crescimento de suas unhas e que a viúva podia ter contado a alguém. Resolveu esquadrinhar o globo terrestre à procura de resposta à sua moléstia, mas nada encontrou.

Ao regressar ao lar, deparou com sua casa em ruínas, a natureza e o tempo selvagens tomaram conta do espaço: móveis podres e decompostos, teias de aranhas dominavam o lugar, o jardim se transformou em uma selva no coração da cidade. "Um ódio tremendo contra todos os seres e contra tudo turvou-lhe a alma e, possesso, quebrava tudo que tinha na sua frente" (RUBIÃO, 2013, p. 129). Henrique dá vazão a um sentimento que ele reprimiu por muito tempo, toda a sua frustração diante do problema que ele não conseguia resolver é exteriorizado por meio da destruição dos objetos que compunham o espaço de sua casa. O cansaço o fez cair desanimado, a sociedade se fechou para ele, pois não tinha mais convites em virtude da constante negação dos convites anteriores; logo decidiu que não iria mais cortar as unhas, não tinha mais motivos para esconder o problema, deixaria que elas crescessem indefinidamente.

Diante de tal decisão, regozijava-se com as lembranças do passado, passou horas e horas alegres com recordações que acalentaram o seu coração, que o levaram a dormir. Quando 
acordou, já era noite, e percebeu algo estranho, suas unhas não cresceram mais, ele podia pegar e manipular a vela que acendeu para verificar o milagre. Passou a noite acordado para validar o ocorrido, inexplicavelmente as unhas não cresciam mais como outrora, ele viu emergir dele uma alegria extraordinária, poderia voltar a frequentar os bailes e as festas, a galantear e cortejar as moças da alta sociedade. "Correu ao banheiro para fazer a barba. Tinha que tomar providências imediatas, chamar o alfaiate, etc. Mas, ao dar com a sua fisionomia no espelho, viu que era tarde. Nele estava refletindo um rosto cansado e velho, rugas e amargura estavam impressos ali” (RUBIÃO, 2013, p. 130).

Quando ele enxerga sua nova imagem no espelho, deixa de idealizar-se com um homem jovem e atlético e passa a se ver como um homem velho, amargurado e preenchido por rugas. O crescimento incomensurável das unhas lhe causara isso, ele "indicia a constatação de que existe algo que, embora seja insignificante e contínuo, perturba sua existência e não possui uma cura científica" (GAMA, 2016, p. 110). A cura para sua moléstia estava dentro dele: a perda da vaidade.

O acontecimento fantástico abala as certezas das personagens e do leitor, ele não é permeado apenas por imagens ilógicas e maravilhosas de cunho físico, mas por acontecimentos sociais e psicológicos atravessados por problemáticas que podem (des)construir o leitor e personagens. O fantástico pinta a realidade e os problemas envoltos nela com tons fortes, usando uma paleta repleta de cores singulares e, porque não, insólitas. Para Schwartz (2016), o insólito escrito por Murilo Rubião é redigido a partir de níveis simbólicos e alegóricos de significação, ele faz críticas aos valores e preconceitos da sociedade, mazelas individuais e coletivas. A partir do fantástico crescimento desenfreado das unhas de Henrique, Rubião critica a vaidade e o egocentrismo das pessoas, que se limitam e se escondem com medo das pessoas perceberem as suas deformidades, pois as unhas só crescem em função da vaidade social da personagem e só param de crescer quando ele a abandona.

\section{Algumas considerações}

No presente artigo, observamos as construções corporais de duas personagens de Murilo Rubião: Bárbara e Henrique, pensamo-las inseridas na obra de Rubião, mas também como metáforas de uma sociedade que determina que tipo de corpos e ações são válidas para os sujeitos. 
De fato, olhamos para dois corpos deformados por pecados; em "Bárbara", a gula da protagonista a torna uma mulher obesa. A personagem anseia pelo mundo e o deseja com tamanha intensidade que se alimenta dele e engorda a cada desejo, o que coloca seu marido a mercê de seus desejos, sem conseguir dizer "não", ele se desfaz de todos os seus bens para realizar as vontades de Bárbara, que só engorda. Assim, Rubião nos permite olhar para uma sociedade que é egoísta, que deseja incessantemente o mundo, mas não devolve nada a ele.

Em "As unhas", atentamos para uma personagem imersa em sua vaidade, que perde horas do seu dia se arrumando, colocando tudo em seu devido lugar e uma ligação demarcado com o espelho. Aqui, destacamos o espelho funcionando como lugar de descobrimento de si e também de estranhamento. O espelho é o lugar da atopia, local de todas as possibilidades, como afirmamos na análise, espaço em que o real e o irreal convergem em uma junção perfeita.

E justamente Henrique, dono de uma vaidade imensa, tem sua vida transformada ao perceber o crescimento descompassado de suas unhas, como analisado durante nosso artigo. Nesse prisma, evidenciamos que essa anomalia faz o processo de redescobrimento da personagem, uma vez que ao se deparar com o problema passa a se isolar socialmente e viver só, o que corrobora que seus valores estavam fixados no externo: na beleza física, na aprovação do outro, e por meio de tal condição, não se percebe inserido em nenhum lugar. Ainda salientamos que, no conto "As unhas", o julgamento parte de Henrique, e não da sociedade, o que valida a ausência de reflexão e autoconhecimento, uma vez que, por falta de conhecimento e/ou criticidade, vivemos a mercê do julgamento do outro, mesmo antes de sermos julgados. E esses julgamentos são algemas invisíveis e patológicas que nos aprisionam.

Ademais, esses corpos deformados que o autor evidencia, faz-nos refletir sobre uma sociedade do controle, que nos dita as regras daquilo que deve ou não ser seguido, como afirmamos, e o descumprimento de tais imposições gera uma transgressão fazendo com que tais personagens tornem-se monstros diante da sociedade.

\section{Referências}

CORDEIRO, C. R. O sujeito fantástico: dualidade ou dualismo?. In.: SIMÕES, M. J. (Coord.). O fantástico. Coimbra: CLP, 2007. p. 43-51.

COURTINE, J.-J. O corpo anormal- História e antropologia culturais da deformidade. In: CORBIN, A.; COURTINE, J. J.; VIGARELLO, G. História do corpo: As mutações do olhar: O século XX. Petrópolis, Rio de Janeiro. Vozes, 2009. 
FOUCAUlT, M. Os Anormais. Tradução de Eduardo Brandão. São Paulo: Martins Fontes, 2010.

GAMA, V. L. A narrativa insólita em Murilo Rubião: um fantástico inquietante e moderno. Tese de doutoramento em Literatura Brasileira. 2016. $171 \mathrm{f}$. Tese (Doutorado em Literatura Brasileira). Faculdade de Letras, Universidade Federal do Rio de Janeiro, Rio de Janeiro, 2016.

GAMA-KHALIL, M. M. As Metamorfoses do corpo e a construção do fantástico nas narrativas de Murilo Rubião. In: GARCIA, F.; BATALHA, M. C. Murilo Rubião 20 anos depois de sua morte. Rio de Janeiro: EdUERJ, 2013. p. 47-66.

GAMA-KHALIL, M. M.. As teorias do fantástico e a sua relação com a construção do espaço ficcional. In: GARCIA, F.; BATALHA, M. C. (Org.). Vertentes teóricas e ficcionais do insólito. Rio de Janeiro: Editora Caetés, 2012. p. 30-38.

REVEL, J. Foucault: conceitos essenciais. Tradução de Carlos Piovezani e Nilton Milanez. São Carlos: Claraluz, 2005.

ROAS, D. A ameaça do fantástico: aproximações teóricas. São Paulo: Editora Unesp, 2014.

RUBIÃO, M. As unhas. In: GARCIA, F.; BATALHA, M. C. Murilo Rubião 20 anos depois de sua morte. Rio de Janeiro: EdUERJ, 2013. p. 125-130.

RUBIÃO, M. Bárbara. In: RUBIÃO, M. Murilo Rubião: obra completa. São Paulo: Companhia das letras, 2016. p. 22-28.

SCHWARTZ, J. O fantástico em Murilo Rubião: uma visita. In.: RUBIÃO, M. Murilo Rubião: obra completa. São Paulo: Companhia das letras, 2016. p. 251-253. 


\title{
Curta Murilo: Insólitas pirotecnias entre textos e tela Murilo Rubião: Unusual pyrotechnics between literary and film narrative
}

\author{
Maria Zilda da Cunha* \\ Maria Auxiliadora Fontana Baseio**
}

\begin{abstract}
RESUMO: É fato que Murilo tornou-se um dos mais importantes escritores do conto fantástico no Brasil e que sua escritura projeta reflexões sempre novas acerca das configurações do insólito tal como se constrói em suas narrativas. Compreende-se com David Roas (2004) que a irrupção do insólito implica experiência inquietante no leitor ante a falta de sentido revelada pela fratura de "representação" referencial da realidade vivida, conduzindo à necessidade de questionamento da validade dos sistemas de percepção do real. O propósito deste ensaio é discutir, à luz dos Estudos Comparados de Literatura, na perspectiva das possibilidades oferecidas pela tradução intersemiótica, proposta por Julio Plaza, as projeções do insólito na narrativa literária de Murilo e na obra fílmica de Olímpio Costa. O conto de Murilo Rubião, "O Ex-mágico da Taberna Minhota", inserido no livro de estreia do escritor mineiro, assinala a irrupção do inesperado, mostrando-se como "uma literatura do contra", conforme Candido (2011). Essa narrativa reverberou variadas transposições intersemióticas, entre as quais a animação de Olímpio Costa, que, à sua maneira, reinventa a genialidade muriliana fazendo casamentos inusitados entre os contos "Teleco" e "O ExMágico", em um roteiro permeado pela atmosfera estética.
\end{abstract}

PALAVRAS-CHAVE: Insólito. Narrativa literária. Narrativa fílmica. Tradução intersemiótica. Murilo Rubião.

\begin{abstract}
It is known that Murilo has become one of the most important writers of the fantastic tale in Brazil and that his writing always projects new reflections on the configurations of the unusual as it is constructed in his narratives. David Roas (2004) understands the irruption of the unusual implies a disturbing experience in the reader before the lack of meaning revealed by the fracture of referential "representation" of the lived reality, providing reflections about the validity of the systems to perceive the real. The purpose of this essay is to discuss, in the light of Comparative Literature Studies, from the perspective of the possibilities offered by the intersemiotic translation proposed by Julio Plaza, the projections of the unusual in Rubião's literary narrative and in Olímpio Costa's film narrative. The tale "O ex-Mágico da Taberna Minhota", from Rubião's first book, marks the irruption of the unexpected, showing itself as "a counter literature," according to Candido (2011). This narrative has reverberated several intersemiotic transpositions, including an animation by Olímpio Costa, who, in his own way, reinvented Rubião's genius by making unusual marriages between the short stories "Teleco" and "O ExMágico" in a script permeated by aesthetic atmosphere.
\end{abstract}

KEYWORDS: Fantastic. Literary narrative. film narrative. Intersemiotic translation. Murilo Rubião.

\footnotetext{
* Pós-doutora em Ciências, Educação e Humanidades pela UERJ, pós-doutoranda em Letras pela Universidade do Minho (Portugal). Professora do Programa de Estudos Comparados de Literaturas de Língua Portuguesa da Universidade de São Paulo, Coordenadora da área de Literatura Infantil e Juvenil e vice-diretora do Centro de Estudos de Literaturas de Língua Portuguesa da USP.

** Pós-doutoranda em Letras pela Universidade do Minho (Portugal), professora do Programa de Mestrado da Universidade de Santo Amaro. Líder do Grupo de Pesquisas Arte, Cultura e Imaginário.
} 
No fantástico moderno há uma necessidade de o escritor impor a sua irrealidade como se fosse real a ponto de o leitor, terminando a leitura, ficar numa certa dúvida se a realidade em que vive não será falsa, e se a realidade verdadeira não será aquela da ficção. Os tempos, a história, obrigam o escritor a tomar uma posição diferente daquela dos séculos anteriores. Não caberiam mais os contos de fadas, o fantástico sombrio, porque o leitor moderno não os aceitaria, se bem que os contos de fadas ainda sejam obras do melhor realismo fantástico, no sentido moderno ou antigo da expressão.

(Murilo Rubião)

Murilo Rubião (1916 - 1991), afeito ao universo do fantástico, com uma publicação de apenas trinta e três contos, estreou, em 1947, com o livro $O$ ex-mágico. ${ }^{1}$

De seus contos emergem metamorfoses admiráveis. Nas pirotecnias murilianas, com frequência, verifica-se o confluir, ora em maior, ora em menor grau, para o horizonte de expectativas do leitor das literaturas infantil e juvenil. O fato é que o criador de $O$ pirotécnico Zacarias frisou sempre que muitos dos elementos de fabulação presentes na sua ficção provêm das leituras realizadas na infância.

Minha opção pelo fantástico foi herança da minha infância, das leituras que fiz, e também porque sou um sujeito que acredita muito no que está além das coisas: nunca me espanto com o sobrenatural, com o mágico, com o mistério. ${ }^{2}$

Seguramente, os escritos de Murilo permitem divisar um repertório rico de narrativas: a Bíblia, a mitologia grega, As mil e uma noites, os contos de fadas e maravilhosos e autores como Miguel de Cervantes e Machado de Assis. Como afirmava o autor, as metamorfoses e o universo do mágico presentes em seus escritos advinham da leitura dessas obras e autores. Chega a testemunhar: "A Bíblia está muito entrelaçada com os meus contos. Eu a li e reli várias vezes, desde a minha infância. Foi um livro imprescindível para o meu trabalho [...] A Bíblia está dentro do que eu escrevo". ${ }^{3}$ E acrescenta Murilo: “[...] a minha literatura, a minha frase, é

\footnotetext{
${ }^{1}$ RUBIÃO, M. O ex-mágico. Rio de Janeiro: Universal, 1947.

2 “O fantástico Murilo Rubião". Entrevista concedida a J. A. de Granville Ponce. Em O pirotécnico Zacarias, 2016, p. 4.

3 O fantástico Murilo Rubião. Entrevista concedida a Maria Esther Maciel e Carolina Marinho, em 1984, republicada no Suplemento em 2011, p. 8.
} 
de grande sobriedade. Tanto é verdade este gosto do estilo mineiro que já disse que Machado parecia um escritor mineiro" 4 .

Dono de uma redação inconfundível, pela precisão do vernáculo e fluência textual, Murilo agencia enredos de matiz obscuro, engendrando acontecimentos na esfera do inverossímil e do absurdo. Na medida em que compõe uma ficção que alia ironia e humor a eventos no âmbito do inexplicável - suas personagens não encontram saída para os infortúnios que as circundam, como se tudo não passasse de equívocos gratuitos -, realiza, com maestria, uma crítica social, apostando na figuração de alegorias veementemente intrincadas.

É inegável a habilidade com que Rubião constrói seus textos para estabelecer novas percepções, interpretações que resultem em experiências de passagem entre a possibilidade e a impossibilidade, o apreensível e o inapreensível.

$\mathrm{Na}$ contística muriliana, perfaz-se um estilo que contrasta os fenômenos absurdos intrínsecos ao fantástico com a matéria narrada, que surge em escrita límpida. O registro linguístico e o seu modus operandi colidem com as contradições que propositadamente engendram os acontecimentos apresentados. Se as vozes da crítica confiadas a Rubião foram sensíveis ao modo obsessivo de suas constantes reescritas, Antonio Candido (2011) foi profético quanto à realização da proeza desse autor. Em um célebre ensaio, o crítico, ao tecer considerações acerca da ficção brasileira dos anos 60 e 70 do século 20, diz ser válido um pequeno recuo para registrar a importância de obras, como as de Clarice Lispector, de Guimarães Rosa e de Murilo Rubião, escritores que injetaram, com excelência, novos elementos na ficção brasileira.

Afirmando ser o conto o melhor da nossa produção recente, o crítico comenta acerca de Rubião:

Com segurança, meticulosa e absoluta parcialidade pelo gênero (pois nada escreve fora dele), Murilo Rubião elaborou os seus contos absurdos num momento de predomínio do realismo social, propondo um caminho que poucos identificaram e só mais tarde outros seguiram. (CANDIDO, 2011, p. 252)

O rompimento "com o pacto realista (que dominou a ficção por mais de duzentos anos), graças à injeção de um insólito que de recessivo passou a predominante" - escreve Antonio Cândido - "teve nos contos de Murilo Rubião o seu precursor" (CANDIDO, 2011, p. 255).

\footnotetext{
${ }^{4}$ Murilo Rubião, em entrevista a Walter Sebastião. Disponível em: <www.murilorubiao.com.br>.
} 
Murilo tornou-se um dos mais importantes cultores do conto fantástico no Brasil, a singularidade de sua escritura, a sua dedicação pelo gênero e a afeição pela constelação do insólito é assinatura das narrativas do autor.

O conto de Murilo Rubião, O Ex-mágico da Taberna Minhota, inserido no livro de estreia do escritor mineiro, pertence, como os demais, à categoria do fantástico. Inverossímil e insólito, o relato vai indiciando fugas às probabilidades de comprovação e sugerindo - como marca definidora do insólito - a irrupção do inesperado: "tampouco me surpreendi ao retirar do bolso o dono do restaurante" ${ }^{5}$ (RUBIÃO, 2016, p. 15). De fato, algo estranho a qualquer referência que delineie a medida do real ocorre.

Assim começa o conto: "Hoje sou funcionário público e este não é o meu desconsolo maior" (RUBIÃO, 2016, p. 15). A narrativa vai refletindo, ao longo de seu desenrolar, um curioso estado de incertezas. O conflito de identidade parece se colocar como elemento substancial na intriga. A história é iniciada em media res por um narrador autodiegético. Alguém que fala de si, mas não sabe quem é. Faz mágica sem saber como. A focalização interna faculta-nos a percepção do perfil de um personagem-narrador acometido por inseguranças:

\begin{abstract}
$\mathrm{Na}$ verdade, eu não estava preparado para o sofrimento. Todo homem, ao atingir certa idade, pode perfeitamente enfrentar a avalanche do tédio e da amargura, pois desde meninice acostumou-se às vicissitudes, através de um processo lento e gradativo de dissabores. [...] Um dia desses dei com os meus cabelos ligeiramente grisalhos, no espelho da Taberna Minhota. A descoberta não me espantou e tampouco me surpreendi ao retirar do bolso o dono do restaurante. Ele sim, perplexo, me perguntou como podia ter feito aquilo. $\mathrm{O}$ que poderia responder, nessa situação, uma pessoa que não encontrava a menor explicação para sua presença no mundo? Disse-lhe que estava cansado. Nascera cansado e entediado. (RUBIÃO, 2016, p. 15)
\end{abstract}

Um mágico, que mesmo sem "casaca e cartola" - e sem saber como -, divertia a plateia, fazendo surgir coelhos, cobras, lagartos e tantos bichos e objetos que se transformavam em outros. Sem dar conta, torna-se um mágico de circo. Mesmo fora do espetáculo: o que tocava transformava em outra coisa. Seu desespero levou-o a mutilar as mãos, que a qualquer movimento reapareciam "novas e perfeitas nas pontas dos tocos do braço" (RUBIÃO, 2016, p. 18). Sem êxito nessa empreitada, decide pelo suicídio: "tirei dos bolsos uma dúzia de leões e, cruzando os braços, aguardei o momento em que seria devorado. Rodearam-me, farejaram minha roupa, olharam a paisagem e se foram”. (RUBIÃO, 2016, p. 18), confessa. Na manhã

\footnotetext{
5 Para este trabalho, utiliza-se o livro Murilo Rubião: obra completa. Edição do centenário. Publicado pela Companhia das Letras, em 2016.
} 
seguinte, quando os animais voltaram, dizendo ao nosso protagonista ser este mundo tremendamente tedioso, pediram que os fizesse desaparecer. Na urgência de encontrar solução: "Matei-os todos e me pus a devorá-los" (RUBIÃO, 2016, p. 18).

Ao ter o seu projeto de suicidar-se logrado, segue seu percurso de desconsolo e fracasso. Um dia, ao ouvir de "um homem triste" que ser funcionário público era suicidar-se aos poucos (RUBIÃO, 2016, p. 19), abandona a profisssão de mágico e emprega-se "numa Secretaria de Estado" (RUBIÃO, 2016, p. 19). Tragicamente, no momento em que decide retirar do bolso o título de nomeação de mais de dez anos, para comprovar uma estabilidade - que não tem -, nada consegue. Com efeito, perdeu o dom da magia. Esmagado pela burocracia e talvez pelo amor não correspondido que o manteve preso no emprego, irá compreender o que poderia ter realizado com seus dotes de feiticeiro. Imagina por uns instantes:

Como seria maravilhoso arrancar do corpo lenços vermelhos, azuis, brancos, verdes. Encher a noite com fogos de artifício. Erguer o rosto para o céu e deixar que, pelos lábios, saísse o arco-íris. Um arco-íris que cobrisse a Terra de um extremo a outro. E os aplausos dos homens de cabelos brancos, das meigas crianças. (RUBIÃO, 2016, p. 21)

Lamenta, ao fim e ao cabo, o fato de não ter realizado "todo um mundo mágico".

Pontas ligadas à esfera do onírico pronunciam-se evocando a cumplicidade do leitor a quem os absurdos incidentes confiam uma recepção diferenciada e a tessitura de interpretações novas. "Tirei dos bolsos uma dúzia de leões e, cruzando os braços, aguardei o momento em que seria devorado" (RUBIÃO, 2016, p. 18). Elementos próprios do fantástico enovelam-se na narrativa. "Também, à noite, em meio a um sono tranquilo, costumava acordar sobressaltado, era um pássaro ruidoso que batera as asas ao sair de meu ouvido” (RUBIÃO, 2016, p. 18).

Se outrora a magia fora uma espécie de expressão de poder propiciada por uma força suprarreal, da sua possibilidade criadora ele só tirara um mínimo concreto: coelhos, pombos, leões, lapiseiras, guloseimas. Não percebera a potência verdadeiramente criativa da magia e de sua insólita manifestação.

Com efeito, as falas e relatos de viés ilógico, figurando a impossibilidade de o personagem-narrador encontrar sua identidade, de se furtar de entraves que exaustivamente os cercam, vão engendrar-se em momentos de lirismo, "como seria maravilhoso arrancar de meu corpo lenços vermelhos, azuis, brancos verdes. Encher a noite com fogos de artifício. Erguer o rosto para o céu e deixar que pelos meus lábios saísse o arco-íris” (RUBIÃO, 2016, p. 21). A 
sobriedade assumida pelo autor engata a uma singular ludicidade que propõe um jogo estimulante que promete e concede trégua aos desatinos do cotidiano.

$\mathrm{Na}$ esteira de Bessière (1974), uma característica do relato fantástico é a de constituirse como uma investigação sobre os limites da razão - lugar de passagem entre realidade e irrealidade, razão e desmesura. Sinaliza a autora que "o fantástico não resulta de uma simples divisão psíquica entre razão e imaginação", mas resulta "da polivalência de signos intelectuais e culturais que se incumbem precisamente de figurar" (BESSIÉRE, 1974, p. 60). Diz ainda a autora que:

O fantástico revela o fundo de cada mecanismo narrativo e restitui a verdadeira função do imaginário: a de difundir a prática e o gosto pela estranheza, de restabelecer a produção do insólito e de fazê-la passar por uma atividade normal. (BESSIÈRE, 1974 apud CESERANI, 2006, p. 69)

Em $O$ Ex-mágico, a produção do insólito reverbera no tecer e destecer da narrativa. No processo de narrar, ocorre a própria atualização criativa do relato fantástico, em constante movimento dialético, no retorno à potência da palavra, à imagem, entre o feito e o fazer. Aí, o fantástico vai praticando o estranho, em liberdade imaginária, dando vez ao experimentável e ainda indizível. Empresa essa análoga à encontrada nas genialmente perversas ilustrações de Grandville (1843), nas insólitas misturas entre orgânico e inorgânico das pinturas de Bosch (1450-1516), que primam pelos diálogos plásticos que se tecem em simulacros sensuais, como as que verificamos também em obras da Literatura Infantil e Juvenil de autores como Neil Gaiman e Tim Burton; na construção de um país de maravilhas e de seres estranhos como o de Lewis Carroll e suas Alices; nas sombras fantasmáticas que movem os livros da artista sul coreana Suzy Lee, nas orgânicas e insólitas assombrações de Angela Lago (que figuram em textos verbais e visuais, em mídias impressas e digitais).

Lembrando David Roas (2014), a irrupção do insólito na narrativa pode provocar - no leitor - uma experiência de indescritível inquietação ante a falta de sentido revelada e percebida no seu contexto real e cotidiano. Deste ponto de vista, ao providenciar essa fratura de "representação" referencial da realidade vivida, ao ameaçar o caráter estável que aparenta ter a realidade, a presença desse elemento surpreendente instaura algo de profundamente realista: a necessidade de questionamento da validade dos sistemas de percepção do real.

A prosaica vida do ex-mágico metaforiza, seguramente, a esterilidade do trabalho burocrático, a acriticidade dos atos do cotidiano, a falta de identidade, a ausência de projetos de vida - tão habituais na contemporaneidade. 
O protagonista do "ex-mágico", como outras personagens dos contos murilianos, não se espanta, apesar do caráter insólito dos acontecimentos que presencia ou vive; essa espécie de suspensão da surpresa certamente encontrará eco oposto em quem lê desprevenido, provocando o susto e, logo, a desconfiança de ser objeto de burla. Ou então, o assombro será, como sempre, o começo da busca do sentido. (ARRIGUCCI JÚNIOR, 2016, p. 13-15)

É fato que a escritura muriliana se abre para reflexões sempre novas, as quais efetivamente reatualizam o debate sobre o projeto ficcional desse autor. A ruptura sinalizada pelo crítico Antonio Candido, acima comentada, revelada como "uma literatura do contra" (CANDIDO, 2011, p. 256), operou-se por meio de recursos diversos (entre os quais os gráficos), foi uma remodelação que atingiu diversas artes e promoveu intenso diálogo entre linguagens. Ao curso dos anos, a narrativa muriliana passou a originar relevantes transposições intersemióticas, obras fílmicas, animações, teatro, quadrinhos e, mais recentemente, migra para o universo dos livros ilustrados de literatura infantil ${ }^{6}$, obras - mais híbridas - que vêm conferir maior visibilidade ao autor. Agamben retoma Walter Benjamin e nos lembra que:

A essência da prosa consiste em perecer, isto é, em ser compreendida, isto é, em ser dissolvida, destruída sem retorno, inteiramente substituída pela imagem ou pelo impulso. (BENJAMIN apud AGAMBEN, 2015, p. 47)

Cem anos após o nascimento de Murilo Rubião e 70 anos depois da publicação do livro O Ex-mágico, pirotecnias iconográficas, que, apesar da lavra da palavra escrita, permanecessem em explosões contínuas pela imaginação do autor de $O$ ex-mágico da Taberna Minhota, ingressam em preto e branco, por meio de ruídos incômodos, nas telas cinematográficas. Vêm a público pela direção e roteiro de Olímpio Costa. ${ }^{7}$

\footnotetext{
${ }^{6}$ Livros ilustrados O Edifício, il. Nelson Cruz; Bárbara, il. Marilda Castanha; Teleco, o coelhinho, il.Odilon Moraes.

${ }^{7}$ O roteiro de Olímpio Costa (1978) foi premiado pela FUNDARPE (Fundação do Patrimônio Histórico e Artístico de Pernambuco) em 2010, foi oficialmente lançado no circuito fílmico com estreia no Festival de Gramado, obtendo o prêmio de melhor som, ganhou prêmio do júri no Festival de Vitória, prêmio do público no Animagi de Recife e prêmio de melhor animação e melhor roteiro no $18^{\circ}$ Festicine de Pernambuco.
} 


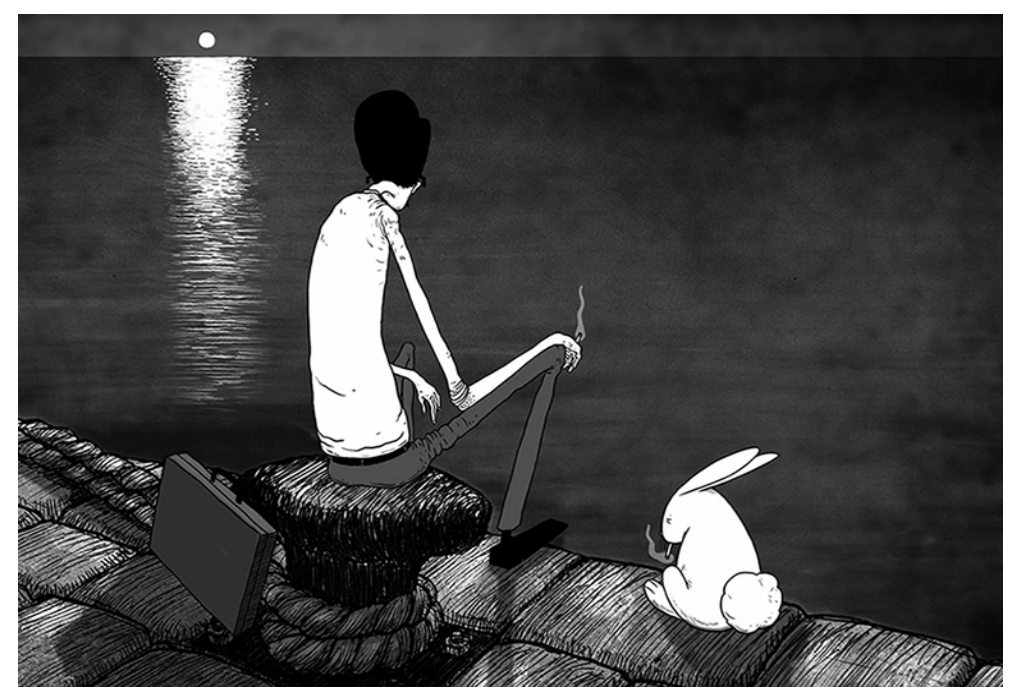

Figura 1. Cena do curta-metragem $O$ Ex-mágico, roteiro e direção de Olímpio Costa ${ }^{8}$

Olímpio Costa, para quem "escrever roteiros é pensar rítmica e visualmente, agregando estes elementos em uma atmosfera estética" (COSTA apud REIS, 2016, p. 180), afirma que $O$ Ex-Mágico da Taberna Minhota, de Rubião, constitui "uma história propícia para o trabalho em modo animação" (idem). Para o roteirista, ela já contém elementos lúdicos, metamorfoses, truques e encantos acontecendo a todo o tempo. Reverenciando a genialidade do escritor mineiro, Olímpio produz, à sua maneira, o que ele denomina "reinterpretação e um diálogo entre os contos “Teleco” e “O Ex-Mágico” (COSTA apud REIS, 2016, p. 181).

A animação divide-se em duas partes, que estabelecem diálogos. No início, reafirmando a filiação literária, aparece, no ecrã - tela branca -, a legenda: "Baseado no conto "o Ex-mágico da Taberna Minhota de Murilo Rubião". Em tela preta, segue a citação bíblica "Inclina, Senhor, o teu ouvido, e ouve-me: porque eu sou desvalido e pobre" (Salmos, LXXXV, 1) - a mesma que serve de epígrafe ao conto muriliano.

A linguagem gráfica escolhida por Olímpio Costa para a animação sobressai-se pela escolha de tons escuros. A presença de hachuras e o uso de tons sombrios, notadamente, constroem o cenário, espaço no qual a figura do protagonista se sobressairá em razão da claridade que possui aliada à sobreposição de sombras acinzentadas e dos traços firmes utilizados na sua composição corpórea. Nota-se que as criaturas animadas ganham coloração

\footnotetext{
${ }^{8} \mathrm{O}$ curta-metragem de 10 minutos e 41 segundos foi exibido, ainda sem os créditos finais, com exclusividade para o Grupo de Pesquisa Produções Literárias e Culturais para crianças e jovens durante a $1^{\mathrm{a}}$. Mo(n)stra Fantástica de Cinema, em dezembro de 2015, com a curadoria de Flávia Reis, Paulo Cézar Ribeiro Filho, Vanessa Zago, Juliana Oliveira e Rogério Cormanich, alunos de pós-graduação da Faculdade de Letras da USP, sob coordenação da Profa. Dra. Maria Zilda da Cunha.
} 
majoritariamente clara e sem hachuras, enquanto os objetos inanimados e os cenários acinzentados e povoados de linhas dão um aspecto rígido, imutável. Formas geométricas linhas retas e quadradas - são as escolhidas para a composição espacial - a cidade é feita de quadrados e retângulos. O personagem tem os pés quadrados, as pernas e o tronco retos. Os traços rígidos do rosto ganham interessante composição com a armação dos óculos que o protagonista usa: são dois quadrados. As formas arredondadas são reservadas para os objetos que resultam das magias realizadas pelo protagonista, bem como reservados para a jovem vizinha de mesa (por quem, no conto, ele é apaixonado). Revisitando a arte das sombras e a arte das silhuetas animadas, afeitas à animação expressionista, dá forças à composição de uma ambientação insólita.

A não linearidade e o aspecto labiríntico da narrativa são corroborados pelo movimento do personagem em constante fuga (o olhar para trás, a ausência de referências - seres surgem e não se sabe de onde vêm - presenças são anunciados por índices reconhecíveis pelo espectador - como se houvesse lugares não acessíveis ou não possíveis de serem vistos, a exemplo, a cena em que não se sabe de onde saiu a pomba, ou se era dela que o protagonista fugia; a presença da ave é sinalizada inicialmente pelo barulho de suas asas; o movimento da corrida do protagonista é indiciado pelo som das passadas rápidas - enquanto a tela negra ainda exibe a citação bíblica. As cenas de corrida, retomadas diversas vezes no decorrer da animação, os ambientes fechados, paredes altas, sinalizam a estrutura labiríntica da narrativa - como se o enredo se construísse em um labirinto no tempo e no espaço. A alusão explícita às telas de Escher - o artista do infinito - o vai e vem - as retomadas, que conduzem a história a novos lugares, sem perder, no entanto, o fio que tece e destece o enredo, dispondo sentidos que o espectador / leitor deverá capturar.

O espaço da casa do personagem - local escuro que aconchega diversos animais: coelho, tartaruga, sapo, leão, macaco, avestruz, morcegos e que nos são revelados à medida que o personagem acende a luz - é ambiente em que convive com a fauna uma grande quantidade de livros espalhados pelo chão, possíveis testemunhos desse protagonista, que, além de fugitivo, é leitor de Machado, da Bíblia, e também escritor. A pomba9 pousa sobre um dos livros.

\footnotetext{
${ }^{9}$ A pomba branca é comumente usada na iconografia cristã. A simbologia da pomba branca representando a paz e esperança provém da passagem bíblica do Antigo Testamento em que uma pomba branca foi solta por Noé após o dilúvio, encarregando-a de encontrar terra firme. A pomba branca, após a sua viagem, retorna trazendo um ramo de oliveira, como uma mensagem a Noé avisando-lhe de que o dilúvio havia baixado e que havia terra e esperança para o homem. A pomba é também uma mensageira de boas notícias.
} 
O som e a imagem entram em consórcio nessa produção. Nesta cena do quarto, cria-se uma tensão pela trilha sonora dissonante aliada ao jogo de luz e de imagens alternadas: dos animais, a de uma pomba pousada entre livros, da expressão do personagem que se encontra junto à porta; a esse jogo de tomadas de câmera segue-se a visualização da mão do protagonista na direção de um pedaço de pau encostado na parede. Por meio de um reflexo, no olho da pomba, que agora tem a cabeça muito próxima do livro A Bíblia Sagrada, percebe-se a aproximação do agressor. Ouve-se a pancada. Um fade out escurece a tela - tudo escurece como se tudo houvesse terminado.

Vai surgindo "O Ex-Mágico" - o título do curta-metragem - em letras brancas sobre o fundo preto, em escritura embaçada, inicialmente de aspecto sinuoso, compondo-se, depois, como fumaça, ou como se iconicamente fosse se espelhando sobre a superfície da água. Esse prelúdio fílmico já antecipa algo. Cremos que, na alegoria, insinua-se a morte da fé e da magia; no engendrar das formas, semioticamente, a escritura migra para cantos mais racionais de uma outra civilização, sinalizando uma espécie de troca de paradigmas.

Com a focalização externa (ponto de vista que não coincide com nenhuma instância intradiegética), o espectador será apresentado ao protagonista, em plano frontal - agora sentado diante de uma máquina de escrever. Ele olha tediosamente para frente, em uma cena estática, que se tornará muito recorrente ao longo do curta. Ao fundo, são ouvidos barulhos do escritório, mas a imagem permanece sem movimento, como se, apesar dos sons, não houvesse nenhuma movimentação real dentro daquele ambiente. A utilização de plano médio que faculta instaurar uma "visão sobre" uma determinada personagem, a imagem fixa e a voz over imprimem à narrativa visual capacidade persuasiva, o espectador é conduzido a visualizar e a ouvir o personagem e a condição a que se submete: "Estou cansado. Nasci cansado e entediado" (O E M, 2016).

Um movimento de câmera leva o espectador a novos recortes do escritório, de outros funcionários (que aparecem sob a forma de sombras e vozes que se sobrepõem); em plano geral, o escritório e seu funcionamento são visualizados, nota-se mínima movimentação que se une ao som e à silhueta de um homem carimbando papéis. Há um alargamento do campo perceptivo e, intelectivamente, depreendemos a metáfora crítica da condição maquínica do homem pós Revolução Industrial, seu hábito repetitivo e automático, a acriticidade de seus gestos, seu aprisionamento à burocracia, a falta de sentido que pode ir além da circunscrição do trabalho e se encaminhar para outras esferas da vida social e pessoal.

Pistas intertextuais conferem ludicidade à narrativa e colidem, assim, com o matiz sombrio da animação; figuram como sinais para um enigma a ser decifrado, ou manifestam-se 
como ícones para um mapa de navegação a ser elaborado. Que diálogos estão tecendo este enredo plástico? A marca da máquina de escrever é TELECO. O personagem, ao sair do escritório, aparece em um píer, sentado ao lado de um coelho, ambos estão fumando - apenas a fumaça nos cigarros se move. Tem-se aqui um entrecruzamento das relações entre este curta que, como anunciado, é baseado em “O Ex-mágico da Taberna Minhota”, de Murilo Rubião, e o conto "Teleco, o coelhinho", do mesmo autor, de modo interessante. Ao voltar a casa, nosso protagonista encontra o quarto diferente do visualizado no prelúdio fílmico. $\mathrm{O}$ zoom em um cartaz na parede remete a Barbosa - grande Mágico ${ }^{10}$ - "mundialmente famoso". Barbosa seria o nome de nosso protagonista? Barbosa, na mesma situação dúbia, era o coelho Teleco, que se metamorfoseava.

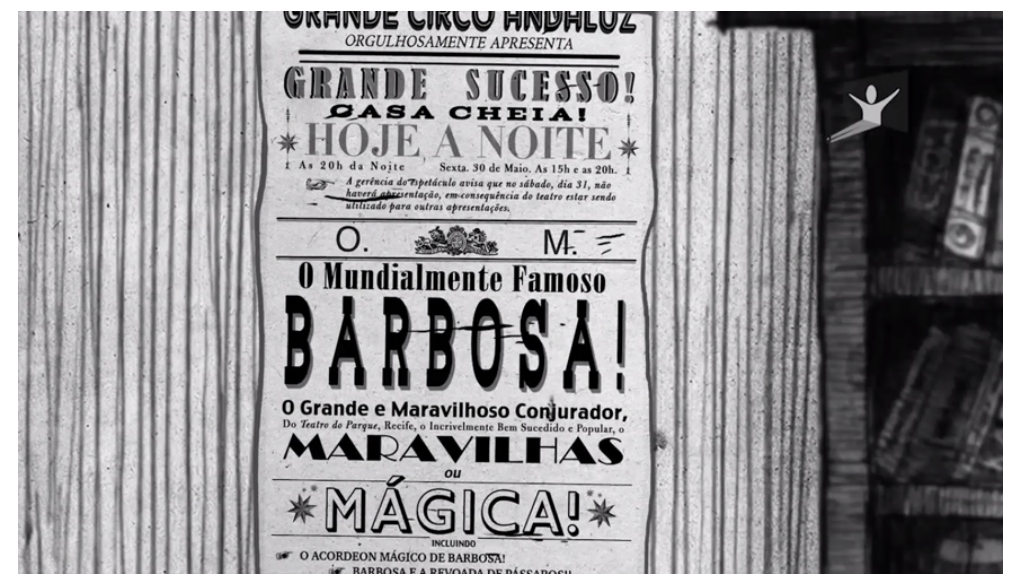

Figura 2. Cena do curta - interior da casa.

Algumas tomadas indiciam as mágicas que ele executava. O bloco de papel que tem a tag "confidencial" recebe o carimbo de "CENSURADO". Teria Olímpio Costa escolhido este trabalho para o protagonista, uma vez que temos um personagem que censurou sua própria magia, a ponto de perdê-la pelos caminhos que escolheu na vida? A voz over retoma as falas do personagem do conto. "No circo, o palco me distanciava das pessoas. Hoje sou funcionário público. E esse não é meu desconsolo maior" (O E M, 2016).

No escritório, visualizamos o personagem pelo mesmo ângulo, sentado na mesma mesa, da mesma forma, cigarro na boca.

\footnotetext{
${ }^{10}$ No conto "Teleco, o coelhinho", de Murilo Rubião (2016, p. 99), lê-se: “Tive mais tarde vagas notícias de um mágico chamado Barbosa a fazer sucesso na cidade".
} 
Nota-se que a luz, o movimento, bem como voos da imaginação são possíveis no que se refere à figura feminina. É o que sugere o curta. Uma pasta de papéis é colocada sobre a mesa, o funcionário olha para os lados, como se quisesse ter certeza de que não está sendo observado. O papel, assim como o cartaz, é mostrado de um ponto de vista por trás da cabeça do personagem, como se olhássemos e o estivéssemos espionando por cima de seu ombro. Ele tosse, uma pena flutua sobre a folha de papel, caindo sobre ela. Assim que encosta na folha, a pena faz pequenas ondas e flutua, como se estivesse sobre água. É o início de um processo de diversas metamorfoses - boca, olhos, seios -, como se, naquela pena, estivesse engasgado todo o desejo (desenho) - do que sente por sua vizinha de mesa. Seu dedo toca em um mamilo e a mão começa a derreter até se desfazer completamente. Voltamos a ver, em plano aberto, a mão do personagem levantada, mas completa, o que indica que o momento anterior se tratou de uma construção fantasiosa do personagem. Mas a pena ainda está sobre a pasta, nem tudo foi uma fantasia.

A rotina, como funcionário público (Barbosa?), é tão repetitiva que tudo pode ter acontecido em uma ordem diferente da contada no curta metragem, em se tratando da memória do personagem que o persegue. "Sem os antigos e miraculosos dons de mago, não consigo abandonar a pior das ocupações humanas. Confiei demais na faculdade de fazer mágicas e ela foi anulada pela burocracia" (O E M, 2016). A narração na voz over deixa claro que os poderes mágicos deixaram o protagonista uma vez que ele optou por se tornar funcionário público.

A cena do almoxarifado vazio apresenta analogia com a imagem da rua, com o leão, o mesmo espaço preto em volta de um pequeno retângulo. O funcionário não entra, deixando o expectador na escuridão por alguns segundos. Holofotes vão iluminar o personagem, como se ele estivesse em apresentação em um palco. A trilha sonora acompanha a mudança, assumindo um clima circense. Dos bolsos saem, além de moedas e notas, vários pássaros e uma borboleta; ouvimos aplausos (pela primeira vez, notamos nosso herói um pouco satisfeito). Ao juntar as mãos, faz aparecer um jacaré entre elas. O animal flutua entre as mãos do mágico por alguns segundos, então ele as une novamente e o transforma em acordeon do qual sairá a melodia que faz a trilha da sequência (em som intradiegético). As mágicas e metamorfoses passam a afetar o corpo do personagem na medida em que de seu rosto sai um pernilongo, que se metamorfoseia enquanto voa. As mais diversas formas são assumidas por objetos e animais que já vimos, como espectadores, em outras cenas: coelho, copo de água, quadrados, papéis, mosca. Por fim, perdem a tridimensionalidade e, como pedaços de papel, tornam-se planos, uma explosão ocorre - como fogos de artifício. Voltamos a ver Barbosa/ funcionário público, que dá origem a mais animais: vemos pombas saindo de seu pescoço, cobras saindo das calças, dos braços 
mais pombas e peixes. Assustado, abre a porta, correndo pela rua, para casa. A cena dessa fuga remete à cena inicial, na qual ele corre olhando para trás, como se estivesse sendo perseguido.

No prelúdio fílmico, o protagonista chega ao apartamento, liga a luz e vê diversos animais espalhados por seu quarto. A sequência da caminhada pela cidade, a da subida pelo prédio e a da chegada ao apartamento são muito similares. Cria-se, assim, a expectativa de que ele encontrará a mesma cena do início.

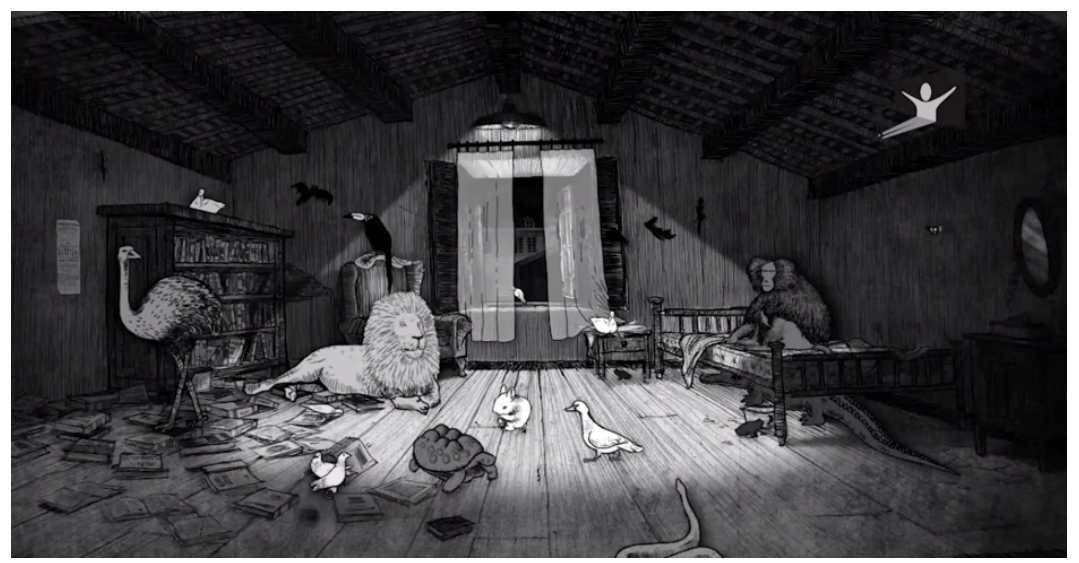

Figura 3. Cena do início do curta

Ao acender a luz, as mesmas figuras lá estão, mas os animais estão mortos, visualiza-se uma cena sangrenta. Do leão, vê-se apenas a cabeça, remetendo mais uma vez ao texto do cartaz que apareceu na parede. O personagem apoia-se na parede, passando mal, vomita pássaros, que logo saem voando. Esta cena remete à do funcionário tossindo e expelindo uma pena na mesa do escritório. Estariam todos aqueles pássaros presos há tempos em sua garganta?

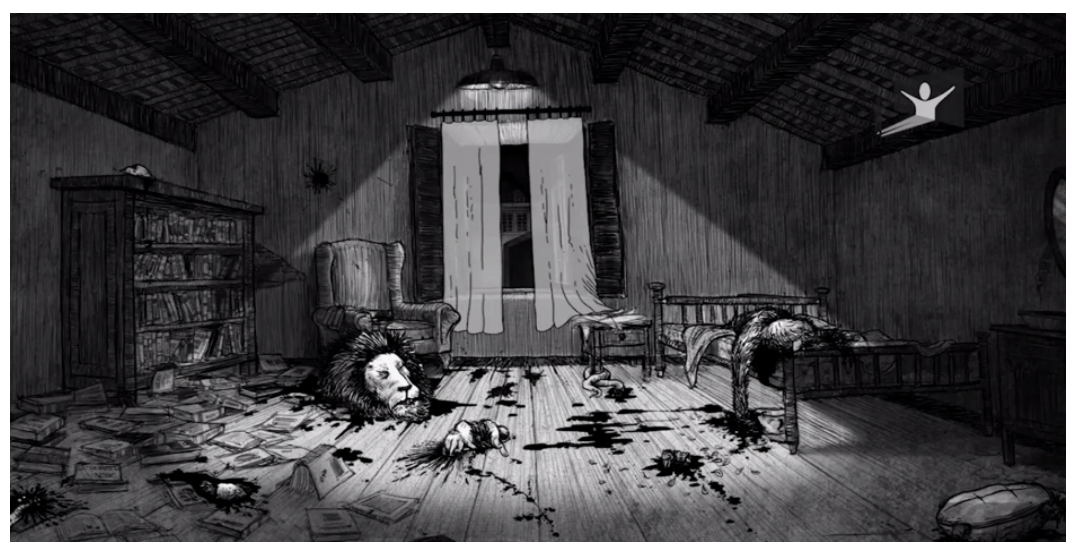

Figura 4. Cena dos 08:07 min. 
Sentado na cama, o personagem olha para a própria mão e, no uso de um cutelo, mutilaa. O corte acontece fácil, sem sangue e parece indolor, mas, assim que a mão se desprende do braço, tornam-se cartas de baralho que se espalham pelo chão. Em segundos, formas difusas ocupam o espaço da mão e formam uma nova mão. Uma arma é levada à cabeça, mas se transforma em um lápis, assim que colocada contra a têmpora. Decepcionado, corre e pula da janela, mas um paraquedas surge em suas costas e se abre em segundos. Vê-se a silhueta do exmágico, cabisbaixo, pousando suavemente. "Eu, que podia criar outros seres, não encontrava meios de me libertar de minha própria existência”, diz a voz over.

Sentado em uma mesa de bar, em ambiente completamente vazio, acende o protagonista um cigarro e se metamorfoseia em coelho. Agora, Barbosa, funcionário, mágico, é, ao mesmo tempo, ele e o coelho que fumava no início.

Uma xícara se quebrando no chão faz a transição para o escritório.

Diante da máquina de escrever, concentrado (talvez escrevendo a própria narrativa), escutamos no curta: "Não morri conforme esperava. Foram maiores minhas aflições". As metamorfoses, agora fora de controle, não impedem a continuidade da escritura. Lembra-nos Teleco. As metamorfoses ocorrem independente de sua vontade e ele parece acostumado a elas. Enquanto escreve - e nos fala (voz over) - sobre a falta que sente de fazer mágicas, a cabeça do protagonista explode, mas retoma a forma em segundos, o cenário altera-se - ele está de volta ao bar, datilografando, pela voz over escuta-se: "Mas não me conforta a ilusão. Serve apenas para aumentar o arrependimento de não ter criado todo um mundo mágico". Ao tirar o papel da máquina de escrever, este se transforma em uma revoada de pássaros, a máquina em uma mosca gigante e uma pilha de papel aparece sobre a mesa, com os óculos quadrados do personagem sobre ela.

A câmera se distancia e vemos, além da mesa, um picadeiro, com a escrivaninha no centro, alguns papéis ainda no ar, como se um truque de mágica acabasse de ser executado. Não há plateia além do espectador de cinema. A luz se apaga e o espetáculo do ex-mágico chega ao fim. 


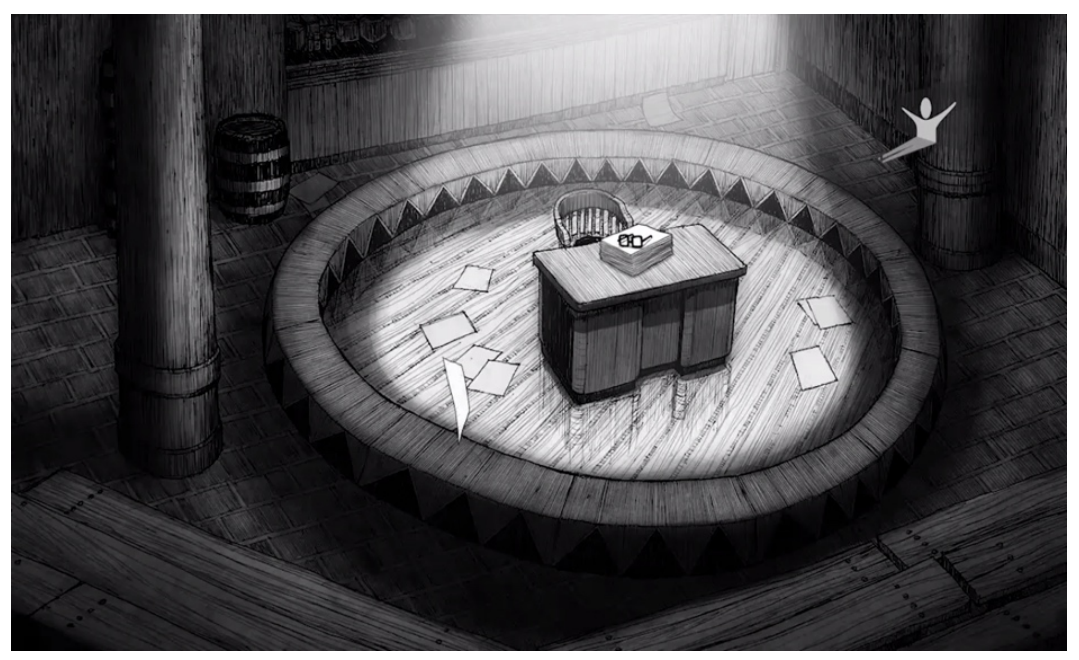

Figura 5. Cena final

Um viés comparativo permite assinalar que, no conto de Murilo Rubião, o que se percebe é que, por via do insólito, há mais humor, ironia, crítica. $\mathrm{Na}$ animação, a condução torna-se mais melancólica, reflexiva e parece trabalhar com a ideia de ilusão/imaginação/loucura. No conto, a vertente crítica/irônica mostra-se também no tratamento junto às crianças: no início do conto, como mágico, lidava com as reações infantis com indiferença, depois, ao final, ao sentir-se desprovido de seus poderes suprarreais, deseja novamente sua magia e menciona as crianças de forma carinhosa (o que também apresenta índices de ironia). Tem-se aqui um movimento circular que sugere mudanças refletidas no personagem narrador em relação. $\mathrm{Na}$ animação, este movimento e a alteração na postura do protagonista não são mostrados - o fio se tece em tom mais melancólico, na fuga de sua magiailusão.

Em ambas as obras - texto e tela -, colocam-se em confronto dois paradigmas: um que se sustenta pela racionalidade instrumental e que promove o desencantamento do mundo assim como assinala Max Weber ao se referir ao processo histórico de desmagificação, de expurgar a magia do seio da vida do homem; e outro que reclama essa dolorosa perda do que já foi e já não é, o ex- mágico, e projeta no fio da palavra e nas metamorfoses da imagem estética um poder ser, capaz de ganhar concretude apenas a partir do gesto recriador daquele que admira o espetáculo.

O mutilar da própria mão - símbolo da vontade e do fazer no mundo - instrumento imprescindível da escritura - e tê-la metamorfoseada em cartas de baralho que se espalham pelo chão são imagens que reverberam esse confronto dos paradigmas e acenam para a possibilidade 
do novo a partir da arte mágica de contar histórias e suspender o tempo ao fazer crer. É a promessa do jogo, para lembrar Huizinga (1971), que se faz presente.

O processo de racionalização observado por Weber envolve mudanças estruturais, culturais e sociais vivenciadas pelas sociedades modernas no decorrer do tempo e que impactaram na construção do capitalismo e no crescimento da vida urbana - base da reordenação das relações sociais e do sujeito moderno - temas caros à obra de Murilo Rubião.

Tanto no livro, como no filme, sobressaem-se críticas à racionalidade formal, relacionada à burocratização das instituições e das relações; nega-se a racionalidade substantiva, que endurece valores norteadores da vida social; ambos os criadores mostram-se solidários às ideias weberianas que criticam a redução da vida moderna à lógica racional, à razão objetiva instrumental, em detrimento dos valores da tradição, ancorados em bases estáveis que sustentavam as crenças religiosas e a magia - rasuradas nos projetos da modernidade. Pulsa, nas narrativas, o sentimento de desolamento, de apatia do sujeito nesse mundo suprarracionalizado.

Ao fim e ao cabo, pode-se observar que, em ambas as obras, a indiferença entre prosa e poesia fratura o limite do discurso e abre brechas no imaginário. Na ruptura entre o discurso e o sistema semiótico, potencializa-se uma experiência do possível entre o verbo e a imagem, onde se situam novidades e a potência criativa do insólito do fantástico. Dito de outro modo, há, no insólito, o potencial do inquietante, o que justificaria o criativo na negação - em cujo centro há um ato de descriação. Diz Agamben (2012):

\footnotetext{
O ato de criação não é, na realidade, segundo a instigante concepção corrente, um processo que caminha da potência para o ato para nele se esgotar, mas contém no seu centro um ato de descriação, no qual o que foi e o que não foi acabem restituídos à sua unidade originária na mente de Deus, e o que podia ser e não foi. Este ato de descriação é, propriamente, a vida da obra, o que permite a sua leitura, sua tradução e sua crítica, e o que, em tais coisas, se trata cada vez mais de repetir. Exatamente por isso, contudo, o ato de descriação, a despeito de toda perspicácia irônica, foge sempre, em alguma medida, do seu autor, e só desta maneira lhe consente continuar escrevendo. (AGAMBEN, 2012, p. 252-253)
}

Diz Agamben (2008, p. 184) que: "o que podia não ser e foi dissipa no que podia ser e não foi", é no meio dessa ambiguidade do negativo, que se figura o poder criador da literatura e da arte em geral. "O ato de criação é ato de pensamento, e um ato de pensamento é um ato criativo, o pensamento criativo define-se pela capacidade de descriar o real: nesta capacidade está o ser negativo e sua atualização em processo" (PALO, 2017). 
Este ato de descriação, na concepção de Agamben,

[...] é, propriamente, a vida da obra, o que permite a sua leitura, sua tradução e sua crítica, e o que, em tais coisas, se trata cada vez mais de repetir. Exatamente por isso, contudo, o ato de descriação, a despeito de toda perspicácia irônica, foge sempre, em alguma medida, do seu autor, e só desta maneira the consente continuar escrevendo. (AGAMBEN, 2012, p. 252-253)

Nesse sentido, os estudos sobre tradução intersemiótica, sintonizados com as novas abordagens dos Estudos Comparados, providenciam condições de operar metodologicamente com o trânsito criativo de linguagens, com os processos de transcodificação criativa, alheios às regras de fidelidade, uma vez que criam possíveis e múltiplas verdades estéticas. Traduz-se o que interessa ao projeto estético, o que provoca empatia como primeira qualidade de sentimento, recria-se o que se afina pela sensibilidade, consoante ao projeto tradutor. Plaza ensina que "criação é deslocamento constante dos signos à procura de sentido" (PLAZA, 2003, p. 35). As novas perspectivas críticas incitam à indagação sobre as razões que levam o autor do texto mais recente a reler e operar esteticamente com os textos mais antigos, na busca de perscrutar os novos sentidos que se engendram nos deslocamentos da narrativa.

O relevante exercício da recepção reforça o inacabamento dos textos e sua descontinuidade, ao permitir a movência e as ressignificações das narrativas no tempo, seus deslocamentos por diferentes códigos e suportes, em diferentes sistemas semióticos. O conto de Murilo Rubião, O Ex-mágico da Taberna Minhota, criou ressonâncias na animação de Olímpio Costa, roteirista que, a seu modo, reinventa-o, em novo código e linguagem.

Considerado como um dos mais importantes escritores do conto fantástico no Brasil, Murilo projeta experiências inquietantes no leitor, trazendo reflexões acerca da validade dos sistemas de percepção do real. Seus contos fantásticos inspiram muitos leitores e deles emergem metamorfoses em diferentes sistemas semióticos. Suas insólitas pirotecnias, regadas de ironia e humor, sustentam críticas sociais bastante contundentes. A vida do ex-mágico metaforiza a imbecilidade do trabalho burocrático, a perda de identidade, a crítica a um paradigma racionalista que acabou por desencantar os sentidos da vida humana.

A animação de Olímpio Costa transcria Murilo com algum gradiente de melancolia, operando no âmbito da ilusão e da loucura. Entre texto e tela, conjugam-se perspectivas que se assemelham no tratamento da crítica ao paradigma racionalista que faz destecer a magia, sugerindo ao leitor/espectador reflexões: haverá uma nova forma de reordenar as relações humanas? 
As pirotecnias murilianas engendram uma forma tensa e densa de escritura, na qual as tão frequentes metamorfoses projetam no texto um insólito movimento. Lembrando Foucault, o que se tece e se destece é a própria "narrativa como acontecimento" (FOUCAULT, 2012, p. 36). O narrador muriliano, por vezes, adentra uma zona de difícil acesso, onde elementos resistem à interpretação e só podem ser tangenciados ou nomeados pela correspondência com imagens (do que ficou por dizer). Recorrendo a Cortázar: "Só com imagens se pode transmitir essa alquimia secreta que explica a profunda ressonância que um grande conto tem em nós, e que explica também por que há tão poucos contos verdadeiramente grandes” (CORTÁZAR, 2004, p. 150-151).

Compreender de que maneira o fantástico se constrói na narrativa do autor do Exmágico da Taberna Minhota e que efeitos essa construção pode desencadear é, de fato, um grande desafio. A ficção fantástica projeta enigmas, notadamente nossas decifrações tangenciam o que não existe na realidade. Seguramente, não deciframos os enigmas postos, mas encontramos fendas para possíveis sondagens do real.

\section{Referências}

AGAMBEN, G. Infância e história. Destruição da experiência e origem da história. Tradução de Henrique Burigo. Belo Horizonte: UFMG, 2008.

AGAMBEN, G. Estâncias. Tradução Selvino José Assmann. Belo Horizonte: UFMG, 2012.

AGAMBEN, G. A potência do pensamento. Ensaios e conferências. Tradução de António Guerreiro. Belo Horizonte: Autêntica Editora, 2015.

ARRIGUCCI JÚNIOR, D. O mágico desencantado ou as metamorfoses de Murilo. Suplemento, Belo Horizonte, n. jun. 2016, p. 13-15, 2016.

BESSIÈRE, I. Le récit fantastique. Paris: Larrousse, 1974.

BESSIÈRE, I. O relato fantástico: forma mista do caso e da adivinha. Revista Fronteiraz, São Paulo, n. 9, dezembro de 2012.

CANDIDO, A. A Educação pela noite. Rio de Janeiro: Ouro sobre Azul, 2011.

CESERANI, R. O fantástico. Tradução de Nilton Cezar Tridapalli. Curitiba: Ed. UFPR, 2006.

CORTÁZAR, J. Valise de cronópio. Tradução de Davi Arrigucci Jr. e João Alexandre Barbosa. Org. Haroldo Campos e Davi Arrigucci Jr. São Paulo: Perspectiva, 2004.

O EX-MÁGICO. Direção: Olímpio Costa e Maurício Nunes. Brasil, Cattleya Produções, 2016.

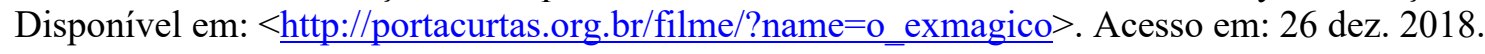


FOUCAULT, M. O que é um autor? Lisboa: Ed. Lisboa: Veja, 2012.

HUIZINGA, J. Homo ludens: o jogo como elemento da cultura. Tradução de João Paulo Monteiro. São Paulo: Editora Perspectiva, 1971.

PALO, M. J. A potência criativa do insólito fantástico. In: CUNHA, M. Z.; MENNA, L. (Org.). Fantástico e seus arredores: figurações do insólito. São Paulo: Ed. USP, 2017.

REIS, F. O ex-mágico: o curta-metragem de Olímpio Costa. Revista Literartes, n. 6, p. 180-188, 2016. REVISTA Literartes. São Paulo, n.6, 2016.

ROAS, D. A ameaça do fantástico: aproximações teóricas. Tradução de Julián Fuks. São Paulo: Editora Unesp, 2014.

RUBIÃO, M. Obra Completa. Edição do centenário. São Paulo: Companhia das Letras, 2016. 


\section{Murilo Rubião e José J. Veiga e a oposição ao racionalismo nos contos "O lodo" e "Os Cascamorros": breves considerações Murilo Rubião and José J. Veiga and the opposition to rationalism in the short stories "O lodo" and "Os Cascamorros": Some remarks}

Fabianna Simão Bellizzi Carneiro*

\begin{abstract}
RESUMO: Através dos contos "O lodo" e "Os Cascamorros", respectivamente de Murilo Rubião e José J. Veiga, faremos considerações acerca de situações que não se encaixam em determinadas condutas e padrões ditados pelos mecanismos de poder na contemporaneidade, atentando para aspectos, depurados pela vertente do Realismo Mágico, que nos apontem a oposição ao racionalismo.
\end{abstract}

PALAVRAS-CHAVE: Realismo Mágico. Racionalismo. Literatura Brasileira.

\begin{abstract}
Through the short stories "O lodo" and "Os Cascamorros", respectively by Murilo Rubião and José J. Veiga, we make some remarks about situations that do not fit in certain behaviors and patterns dictated by power mechanisms in the contemporaneity. From the perspective of Magic Realism, we particularly look into aspects that point us to an opposition to rationalism.
\end{abstract}

KEYWORDS: Magic Realism. Rationalism. Brazilian Literature.

\section{Notas introdutórias}

As narrativas inseridas na vertente do Realismo Mágico costumam expressar um tom contestatório, porém enoveladas por certo encantamento e estranheza, auferido nos contos " $\mathrm{O}$ lodo", do escritor Murilo Rubião e "Os Cascamorros", do escritor José J. Veiga. Respectivamente publicados pela primeira vez em 1965 e 1968, os dois contos problematizam (ainda que de forma inaudita) conflitos humanos, que muitas vezes tentamos aplacar ou esconder.

Os pontos de contato entre o surreal e o cotidiano fazem da escrita de Veiga e Rubião uma escrita única e singular, principalmente ao percebermos que a maioria dos espaços de suas narrativas situa-se em contextos familiares, daí que classificar suas obras apens como textos surreais, impossibilita-nos fazer leituras sociológicas e filosóficas de nossa interação com pessoas e espaços que nos circundam: "É nessa translação que J. Veiga tem seu jeito próprio de instaurar o curso do fantástico [...], convergindo os diversos planos do real." (SOUZA, 1990, p. 33), ao passo que em Murilo Rubião, o fantástico intercepta dois importantes aspectos: a

\footnotetext{
* Doutoranda em Estudos de Literatura pelo Programa de Pós-Graduação em Letras da UERJ. É Mestre em Estudos da Linguagem pela UFG onde também atua como professora contratada desde o ano de 2013. Integra o grupo de pesquisa Mundos possiveis do insólito ficcional.
} 
função do consciente e a força do fator social, contribuindo para alargar a carga dramática de seus contos (LUCAS, 2012, s/p).

Uma vez inserido no universo do fantástico, o leitor perceberá que o local do estranho, do irreal ou do insólito, pode fornecer muitas pistas de que o mundo retratado não está tão distante de sua própria realidade, por mais conflituosos e instáveis que os acontecimentos sejam. Afinal, que mundo teríamos se nosso dia a dia fosse homogêneo, linear ou carente de diferentes e inúmeras histórias que fazem com que cada pessoa tenha sua própria inserção em um mundo tão prenhe de diversidades sob vários aspectos (cultural, religioso, social, sexual) e por isso mesmo tão fascinante e rico?

Pistas que podem ser observadas nos contos "O lodo" e "Os Cascamorros". Nos dois contos nota-se a presença de elementos muito recorrentes em narrativas próprias da literatura fantástica, tais como: a presença do insólito, surpresa, terror e humor. Mas é da realidade que nos cerca que Veiga e Rubião pinçam os elementos que tecem suas narrativas, conforme a seguir atestaremos.

\section{O Fantástico e a vertente Realismo Mágico}

José Veiga nasceu no dia 2 de janeiro de 1915, em um pequena fazenda situada na divisa dos municípios de Pirenópolis (GO) e Corumbá (GO). Faleceu em outubro de 1999, no Rio de Janeiro. Antes de se tornar (ainda em vida) um escritor famoso no Brasil e no exterior, Veiga percorreu um caminho distante do mundo literário: atendente de caixa, advogado, radialista e funcionário público.

Também pelo caminho do jornalismo começa a despontar a escrita de Murilo Rubião. Nascido em 1916 na cidade de Silvestre Ferraz (MG), que posteriormente se chamaria Carmo de Minas (MG), o escritor graduou-se em Direito. Com passagens pelo periódico Folha de Minas e pela Rádio Inconfidência, Murilo Rubião lança seu primeiro livro de contos $O$ exmágico em 1947, porém, é com o livro de contos O pirotécnico Zacarias, lançado em 1974, que o escritor mineiro teria súbito reconhecimento.

Recorrente na obra dos dois escritores é a manifestação do insólito, utilizado como importante recurso de forma a revelar ao leitor temas bem mais profundos e inquietantes. Notase, na escrita de ambos, um legado literário do qual sobressaem textos que não deixam de trazer temas inerentes à nossa realidade, embora tratados pelo viés do insólito. E ao produzirem textos onde questões cotidianas se mostram exageradas ou distorcidas, Veiga e Rubião tornar-se-iam, 
no Brasil, os precursores de uma das vertentes literárias do Fantástico, o Realismo Mágico. Cabem, nesse ponto, algumas considerações a respeito do Fantástico e o que consideramos como suas vertentes.

Dentre os vários críticos que se debruçaram sobre a ardilosa tarefa de buscar conceitos e aportes teóricos para o Fantástico, recorremos ao trabalho de Tzevan Todorov na obra Introdução à literatura fantástica (2008). Todorov salienta que o âmago do fantástico reside no fato de que as narrativas que o processam o fazem através de acontecimentos que não podem ser explicados pelas leis do mundo empírico. $\mathrm{O}$ autor ainda esquadrinha seus estudos, ao cotejar que as narrativas inseridas no Fantástico podem processar os acontecimentos insólitos através de diferentes gêneros, como o estranho puro, o fantástico-estranho, o fantástico-maravilhoso ou o maravilhoso puro, e aqui destacamos o gênero maravilhoso exótico por se aproximar de nossos estudos concernentes ao Realismo Mágico. De acordo com Todorov (2008, p. 61), no maravilhoso exótico são narrados “[...] acontecimentos sobrenaturais sem apresentá-los como tais; supõe-se que o receptor implícito desses contos não conheça as regiões onde se desenrolam os acontecimentos; por conseguinte não tem motivos para colocá-los em dúvida”. E para entendermos como o Realismo Mágico é lido, principalmente para os teóricos mais contemporâneos, como uma vertente do Fantástico (e como a literatura se apropria do termo Realismo Mágico), é preciso que se faça uma breve incursão pela produção literária que marca a segunda metade do século XX, especialmente a literatura produzida por autores latinoamericanos.

Antonio R. Esteves e Eurídice Figueiredo (2010) defendem que o século XX marca a maturidade literária da Hispano-América. Os autores salientam que a Europa inicia um processo artístico de ruptura com os modelos realistas dos oitocentos. Tal processo, ao atravessar o Atlântico e se firmar em solo hispânico-americano, fez com que se quebrassem as fracas bases da narrativa da época, “[...] baseada em um modelo exógeno, que confundia a realidade com a descrição da exótica paisagem local e das complexas relações sociais herdadas dos modelos coloniais aqui implantados" (ESTEVES; FIGUEIREDO, 2010, p. 393). Nasce, então, uma literatura engajada, que trazia temas atuais, como a crise do homem americano que entrava no mundo industrializado, mas que ainda vivia em um ambiente agrário e rural (ESTEVES; FIGUEIREDO, 2010, p. 394). Nomes como Jorge Luís Borges (1899-1986), na Argentina; Arturo Uslar Pietri (1906-2001), na Venezuela; Miguel Ángel Asturias (1899-1974), na Guatemala; João Guimarães Rosa (1908-1967), no Brasil, se destacam no cenário artístico e literário internacional, fomentando um movimento conhecido como boom da literatura hispanoamericana (ESTEVES; FIGUEIREDO, 2010, p. 394). 
Importante mencionar que o termo Realismo Mágico se manifesta, inicialmente, nas artes plásticas: “A crítica tem sido unânime em apontar Franz Roh como o primeiro a usar o termo, em seu livro Pós-expressionismo, realismo mágico. Problemas relacionados com a pintura europeia mais recente, publicado em Leipzig, em 1925” (ESTEVES; FIGUEIREDO, 2010, p. 395, grifo nosso). Aliás, as vanguardas europeias da década de vinte do século passado passariam a usar o termo por alguns anos nas artes plásticas. Aplicado ao contexto literário é o escritor venezuelano Arturo Uslar Pietri quem utiliza o termo pela primeira vez: "Em Letras y hombres de Venezuela, de 1948, ao analisar a produção de contos daquele país, nos anos de 30 e 40, ele aponta como tendência predominante o realismo mágico." (ESTEVES; FIGUEIREDO, 2010, p. 396).

É nesse contexto que surge o Realismo Mágico, vertente do Fantástico que atesta uma nova visão diante do real face contundentes acontecimentos que grassavam especialmente no continente latino-americano, além do que a presença da vertente, em muitas narrativas, encaixou-se em momentos políticos tensos, especialmente entre as décadas de 30 e 60 do século $\mathrm{XX}$, quando pessoas desapareciam por conta dos regimes ditatoriais. As artes, e a arte literária em particular, começam a produzir materiais que simbolizavam "[...] a ambiguidade existente desde o princípio e aparentemente sem solução" (ESTEVES; FIGUEIREDO, 2010, p. 398). Com o correr das décadas, não afirmamos que a vertente tenha se extinguido, mas que apenas tenha ganhado novos rumos e direções:

Passado, também, ao que parece, o desejo homogeneizador que tem suas raízes na utopia de uma grande América, a tendência é que tais conceitos adquiram outros matizes, mais condizentes com a multiplicidade dessa realidade cultural. (ESTEVES; FIGUEIREDO, 2010, p. 413)

Matizes que podemos notar em Veiga e Rubião, que através de suas narrativas revelam a pungente história do nosso país na segunda metade do século XX, marcada por tiranias de toda ordem, opressão, governos ditatoriais, exploração econômica, extração das riquezas naturais em nome do avanço econômico mundial, um sistema educacional enfraquecido, decadência do sistema hospitalar. De acordo com François Laplantine em O que é imaginário, o autor defende que "Não são apenas as narrativas fabulosas que são extraordinárias e extravagantes [...] mas a própria realidade que se apresenta como uma realidade alucinada" (2003, p. 65).

Os autores latino-americanos começam, portanto, a trazer uma escrita não mais pautada no "surrealismo estereotipado" (CHIAMPI, 2008, p. 20), que resgatava os valores dos nativos 
enovelados por um tom folclórico, documental e regionalista. Essa escrita que surge, rompendo com o tradicional esquema do romance, propõe uma nova estética trazendo "outras soluções técnicas para constituir uma imagem plurivalente do real." (CHIAMPI, 2008, p. 21). Uma imagem plurivalente que não se encerra em textos panfletários, valorativos ou folclóricos, mas textos que fornecem um pedaço da história e das sociedades latino-americanas amarrados em discursos ficcionais cuidadosamente elaborados pelo artista:

Querer, ou acreditar que seja possível, uma separação entre o substrato econômico-social de uma determinada sociedade e os planos educativos, artísticos, literários ou filosóficos em que se manifestam, assim como pensar que esses planos podem ser encarados criticamente de forma independente daquele substrato é, atualmente, uma grande ingenuidade, quando não um claro desejo de enganar ou ser enganado. (RAMA, 2008, p. 65)

No mundo real jamais teríamos pessoas que misteriosamente somem e reaparecem sendo carregadas dentro de bolhas, como no conto de José J. Veiga "Os do outro lado", publicado em 1955, porém temos tristes relatos de pessoas que sumiram durante o Regime Militar em vários países da América Latina. Veiga e Rubião, através de um discurso ficcional, não deixam de mencionar os dissabores de nossa realidade - uma realidade nem um pouco fantasiosa, conforme notamos nos contos em análise, "Os Cascamorros" e "O lodo".

\section{0 insólito nos contos "Os Cascamorros" e "O lodo"}

As narrativas analisadas se aproximam em vários aspectos, mas primordialmente pelo fato de trazerem personagens que buscam uma explicação racional para uma ocorrência aparentemente insólita. No conto de Veiga, primeiramente, desenha-se a história de um homem que diariamente passava em frente a uma loja e ficava intrigado com os dizeres de uma placa. O enredo gira em torno de conversas entre esse homem (o visitante), e o dono da loja - cada um tentando justificar suas posições e pontos de vista. Em princípio, o que instigava o visitante não eram os dizeres em si, mas o tipo de escrita:

O que chamava a atenção não era tanto a frase, mas a posição que o pintor deu às letras. Umas ficavam deitadas, outras de cabeça para baixo, outras eram vistas meio de lado, só umas duas ou três apareciam na posição certa, e o "S" vinha sempre de costas. E o mais curioso era que as letras nem estavam na ordem certa, e muito menos no alinhamento. Verdade que ninguém precisava forçar a cabeça para decifrar o que diziam, a frase saltava aos olhos quase que 
instantaneamente: COMPRA-SE, TROCA-SE PROBLEMAS. (VEIGA, 2000, p. 117)

Para alguém que segue a linha de algo classificado como racional ou lógico, quebrar essa ordem e aceitar outra visão de mundo, soa como algo estranho ou até mesmo inconcebível, e aqui cabem os estudos de Deleuze e Guattari (1997) a respeito dos “espaços lisos" e "espaços estriados". No conto de Veiga, a desordem das letras em muito incomoda o visitante, cabendonos uma leitura de nosso próprio mundo, onde muitas vezes nos adaptamos ao espaço estriado, que de acordo com os estudos de Deleuze e Guattari, seria o espaço do ajuste e da ordem:

[...] o que ocupa o espaço liso são as intensidades, os ventos e ruídos, as forças $\mathrm{e}$ as qualidades tácteis e sonoras, como no deserto, na estepe ou no gelo. Estalido do gelo e canto das areias. O que cobre o espaço estriado, ao contrário, é o céu como medida, e as qualidades visuais mensuráveis que derivam dele. (DELEUZE; GUATTARI,1997, p. 163)

Deleuze e Guattari (1997) tiverem um especial cuidado ao analisarem os espaços lisos e os espaços estriados, relacionando-os ao nosso modus vivendi. Nossa vida é feita de estratos e vetores que se cruzam: “A estratificação é como a criação do mundo a partir do caos, uma criação contínua, renovada, e os estratos constituem o Juízo de Deus [...]” (DELEUZE; GUATTARI, 1997, p. 191), daí que os espaços lisos muitas vezes nos tiram o conforto e a segurança que tanto almejamos. No conto "Os Cascamorros', o visitante mostra-se muito incomodado com o espaço de uma loja que está fora de seus parâmetros de normalidade e racionalidade, daí a necessidade de querer impor suas veleidades como se fossem as únicas plausíveis. É justamente essa problematização de uma realidade estranha, inconcebível e lisa, aos olhos do visitante, que dá o tom do Realismo Mágico e que se faz presente no conto "Os Cascamorros". O visitante tenta dar explicações racionais a um fato inaudito, como se isso pudesse manter a zona de conforto dos estriamentos, tão almejados em nossas vidas. Ao entrar na loja, o visitante dialoga com o lojista no intuito de entender o que seria exatamente a compra ou troca de problemas: como eles são mensurados, como são embalados e como são armazenados no interior da loja. Sem conseguir explicações racionais para um fato tão incomum, o visitante se deixa levar, educadamente, pelas convicções do lojista e não mais o questiona a respeito do fato. Ademais, a hostilidade com que o vendedor trata o visitante tonaliza quase toda a narrativa:

- O senhor senhor me desculpe. Eu não sabia dos degraus e... 
- Não vem ao caso. Não vem ao caso - assegurou ele com certo mau humor. - O senhor deseja?...

A frase ficou suspensa numa interrogação antipática, enquanto eu pensava se queria realmente conversar com ele ou se faria melhor virando as costas e saindo. Ele deve ter notado minha inclinação à desistência, porque logo mudou de tática. (VEIGA, 2000, p. 117-118)

A partir desse momento, o dono da loja mostra-se mais receptível, o que não faz com que o visitante sinta-se mais à vontade ou menos desconfiado - este deixa claras pistas de possuir um olhar bastante racional, sobretudo no interior de uma loja que compra e troca problemas: "Mesmo notando que ele me estudava com seus olhinhos aguçados, olhei em volta para ver se deduzia alguma coisa pelo que estivesse à mostra na loja.” (VEIGA, 2000, p. 118). O proprietário, então, retruca, dizendo que se o visitante tinha apenas curiosidade pela placa (como todos os outros) era porque seu interesse seria apenas acadêmico.

Mais do que valorizar um olhar que se pretende racional, o visitante tenta, ao longo da história, entender como uma pessoa pode comprar e trocar problemas - algo inaceitável aos olhos de um personagem que mantém uma postura acadêmica. No conto de Veiga o dono da loja intui possuir um saber que faz com que ele olhe o visitante como louco ou desajustado. No intuito de não chatear ou aborrecer o proprietário do pequeno comércio, o visitante ainda tenta se mostrar gentil dizendo que talvez, no futuro, viesse a ter problemas a serem vendidos. Então o proprietário retruca: “Quando tiver? Tem certeza de poder falar assim? No futuro? Pense bem.” (VEIGA, 2000, p. 119). Tal observação faz com que o visitante sinta-se abalado em sua posição de pesquisador: "A sem-cerimônia da observação desconcertou-me, e devo mesmo ter corado; felizmente ele não pôde notar essa minha vulnerabilidade devido à escuridão da loja." (VEIGA, 2000, p. 119, grifo nosso).

Aqui cabem as palavras de Foucault proferidas na obra Resumo dos cursos do Collége de France (1997). Mais do que estudar o intelecto de uma pessoa, interessa, para Foucault (1997, p. 109, grifos do autor), concatenar a inserção dos sujeitos e as experiências e conhecimentos que eles trazem para as sociedades:

O fio condutor que parece ser o mais útil, nesse caso, é constituído por aquilo que poderia se chamar de "técnicas de si", isto é, os procedimentos, que, sem dúvida, existem em toda civilização, pressupostos ou prescritos aos indivíduos para fixar sua identidade, mantê-la ou transformá-la em função de determinados fins, e isso graças a relações de domínio de si sobre si ou de conhecimento de si sobre si. Em suma, trata-se de recolocar o imperativo do "conhecer-se a si mesmo", que nos parece tão característico de nossa civilização, na interrogação mais ampla e que lhe serve de contexto mais ou menos explícito: que fazer de si mesmo? 
Reitera-se que não podemos pensar em nossas experiências cotidianas e em nossas inserções sociais sem a interação com o outro. Não mais segregando os loucos, as minorias, os desajustados e os irracionais, mas considerando-se “[...] o governo de si por si na sua articulação com as relações com o outro (como é encontrado na pedagogia, nos conselhos de conduta, na direção espiritual, na prescrição dos modelos de vida etc.)" (FOUCAULT, 1997, p. 111).

No conto "O lodo", entretanto, percebemos que o racionalismo mostra-se como uma urgência por parte do personagem principal, Galateu. Os primeiros parágrafos da narrativa já nos fornecem tais indícios:

Lamentava rer aceitado o conselho de procurar a clínica do doutor Pink. Uma depressão ocasional, e caíra nas mãos do analista. Por desconhecer até aquela data a existência de semelhante especialidade, achou estranho o comportamenro do médico, que nada receitara nem demonstrara interesse pelos sintomas da doença.

Galateu não sabia se estava realmente enfermo, mas era fora de propósito ser obrigado a deitar-se num divã e ouvir uma série de perguntas imbecis sobre a sua adolescência:

- Doutor, vim vim atrás de clínico, não de padre. (RUBIÃO, 1998, p. 235)

O médico, então, receita ao enfermo um longo tratamento com sessões de terapia, uma vez que ele "[...] carregava dentro de si um imenso lodaçal". Empregado de uma Companhia de Seguros Gerais, ocupação burocrática e altamente racional, Galateu mostra-se irredutível, passando a desprezar os conselhos do terapeuta e recusando-se a atender seus telefonemas, ao que o médico problematiza:

- Você não compreende que o seu inconsciente é lodo puro?

- Até agora só entendi que o senhor confunde medicina

com catecismo.

- Engano seu. Não quero salvá-lo, mas curá-lo.

- Bem, doutor, sua conversa é instrutiva, porém outra pessoa mais interessante me aguarda. Só espero que este nosso diálogo não se transforme em cifras. Ao despedir-se, ainda era um homem bem-humorado. (RUBIÃO, 1998, p. 237)

Durante muito tempo, pessoas tidas como “desjustadas" eram segregadas e recolhidas em hospitais e manicômios a fim de que fossem tratadas pelos sistemas de poder, incluindo sessões de choque e prescrição com remédios inadequados:

[...] a loucura foi ativamente excluída da cena social, lançada que foi nos hospitais gerais, instituições constituídas no alvorecer do século XVII e onde foi jogada toda a marginalidade do Antigo Regime. Entre os criminosos, os infames, os basflemadores e os infiéis foram lançados também os loucos de 
todo gênero, constituindo-se materialmente o território Outro da desrazão e marcando-se com isso a exclusão da loucura da moderna cena social. (BIRMAN, 2000, p. 37)

Na obra Entre cuidado e saber de si (2000), Joel Birman defende uma posição mais ativa e menos disciplinar da área psiquiátrica, que possibilite aos pacientes condições para que tenham voz própria. Nossa atuação de vida, na contemporaneidade, requer mais inclusão e uma interação maior entre pessoas, ao invés da promoção do isolamento e da alienação de pessoas tidas como desajustadas.

No conto "O lodo", o médico, representante da ciência, tenta devolver ao enfermo possibilidades não convencionais de tratamento, porém pelas vias da imposição, uma vez que o médico não dá possibilidades ao paciente de questionar sua condição, obrigando-o a comparecer às sessões:

No dia seguinte,coube à secretária do analista lhe telefonar:

O doutor, ficou aborrecido com o seu procedimento ontem e pede para avisálo que estará à sua disposição no horário combinado.

- Nada combinei. Por favor, me deixe em paz. - Percebeu, insatisfeito, que começava a implorar.

- A ligação fora cortada e ele permanecia imóvel diante da janela do escritório. Uma recordação desagradável aflorava do passado. Apreensivo, deslocou-se para sua mesa. (RUBIÃO, 1998, p. 237)

Essa vulnerabilidade, se não controlada e escondida, seria capaz de desconstruir a imagem lúcida e altamente racional do paciente. Mais do que se preocupar com a punição do outro, o paciente se auto-regula e se auto-controla, através de um rigor disciplinar que consegue mantê-lo dentro dos parâmetros exigidos pelo seu cargo e pela posição que ele ocupa na sociedade: um homem "normal" que trabalha em um escritório e desenvolve um trabalho burocrático.

Em Microfisica do poder (1979), Michel Foucault aborda as instâncias de atuação do intelectual na contemporaneidade, evidenciando que sua arena de luta deve ser sempre contra o poder e não a favor dele. Não mais falando às massas, mas permitir que estas tenham suas próprias vozes:

Ora, o que os intelectuais descobriram recentemente é que as massas não necessitam deles para saber; elas sabem perfeitamente, claramente, muito melhor do que eles; e elas o dizem muito bem. Mas existe um sistema de poder que barra, proíbe, invalida esse discurso e esse saber. Poder que não se encontra somente nas instâncias superiores da censura, mas que penetra muito profundamente, muito sutilmente em toda a trama da sociedade. Os próprios 
intelectuais fazem parte deste sistema de poder, a ideia de que eles são agentes da "consciência" e do discurso também faz parte desse sistema. O papel do intelectual não é mais o de se colocar "um pouco na frente ou um pouco de lado" para dizer a muda verdade de todos; é antes o de lutar contra as formas de poder exatamente onde ele é, ao mesmo tempo, o objeto e o instrumento: na ordem do saber, da "verdade", da "consciência", do discurso. (FOUCAULT, 1979, p. 71, grifos do autor)

A auto-crítica que Galateu realiza fundamenta-se no excerto acima: não permitir que se aflorem outras verdades e outros olhares acerca da realidade que nos circunda. Existe, no plano ficcional, uma simbologia que circunda o "lodo" e que estaria suficando Galateu. Embora não possamos esmiuçar o que esses problemas representariam, o fato é que a verdade do homem estava sendo arrebatada pela verdade do médico:

Procurou concentrar-se no trabalho, mas o pensamento girava enrte o episódio sepultado no inconsciente e curiosidade malsã do doutor Pink. Insurgia-se contra essa intromissão em sua vida, receoso que o médico pressentisse a verdade toda. (RUBIÃO, 1998, p. 237)

A partir daí, Galateu não consegue mais se concentrar em seu trabalho, muito menos em seus afazeres diários, tendo recorrentes sonhos em que um estranho episódio o acomete:

Só pôde dormir, à noite, tomando uma dose elevada de barbitúricos. Sono agitado, com pesadelos e uma dor dilacerante,que não sabia se real ou apenas sonho. Uma faca penetrava-lhe a carne, escarafunchava os tecidos, à procura de um segredo. Sua irmã Epsila e o analista, debruçados sobre o seu corpo, acompanhavam atentos os movimentos irregulares da lâmina. Na ânsia de acordar, rolava na cama, empapando de suor o travesseiro.

Ao acordar, o homem assim relata o que de fato ocorrera:

A duro esforço conseguiu despertar. Apalpou o peito e as mãos enconrraram uma cojsa pegajosa. Meio enrorpecido pela açáo dos soníferos, buscou no banheiro o espelho e viu que o mamilo esquerdo desaparecera. No lugar desponrara uma ferida sangrenta, aberta em pétalas escarlates. Passado o espanto e superada a náusea, quis chamar um médico. Só não o fez ante o remor de repetir-se a infeliz experiência que tivera com o doutor Pink. Preferiu medicar-se na farmâcia da esquina. $\mathrm{O}$ farmacêutico lhe receirou uma pomada cicatrizante, garantindo a cura em poucos dias de aplicação, o que de fato ocorreu. (RUBIÃO, 1998, p. 238)

O embate, nesse conto, se dá em uma arena dominada pela lógica do médico, que tenta extrair a "verdade" ou a racionalidade do paciente, o que vai ao encontro das colocações de Chiampi (2008, p. 57), em relação ao Realismo Mágico enquanto vertente do Fantástico: 
Como em toda narrativa fantástica, a falsidade lúdica das premissas improváveis é sustentada pela motivação realista, cuja mediação assegura o efeito chocante que o insólito provoca num universo reconhecível, familiar, estruturado.

O efeito chocante acima citado por Chiampi e que se apresenta no conto "O lodo" traz uma interessante relexão: uma flor escarlate nascendo no lugar de um mamilo metaforiza um movimento muito caro aos estudos psicanalíticos: em nosso mundo cotidiano e empírico, escondemos nossas angústias, escabrosidades, aflições e dissabores a ponto de nos suforcarmos. Em algum momento de nossas vidas, essas angústias precisam afloram, do contrário podemos desenvolver algum tipo de surto psicótico.

As artes podem se configurar como um importante (e para muitas pessoas necessário) aliado psicoterápico, ao nos permitir que extravasemos nossas angústias, fato muito bem assinalado no conto "O lodo" e que nos aproxima do conto "Os Cascamorros", quando da passagem em que o visitante e o dono da loja divagam a respeito da balança que media os sacos de problemas, cada um com seus diferentes pontos de vista:

Eu estava mesmo com pouca sorte. Se tivesse me oferecido um metro em vez de uma balança eu poderia fazer os gestos que ele esperava de mim sem denunciar a minha atrapalhação. Porque só há um jeito de medir com metro, que é juntar e separar repetidamente os polegares, tocando com eles as extremidades do metro.

Quando já me parecia que a única saída seria expor francamente a minha atrapalhação, ele virou o mostrador da balança para o lado dele, tirou um caderninho com lápis do bolso do colete, consultou o mostrador e disse:

- É. Mais ou menos o que eu calculei. Errei por pouco - assentou qualquer coisa no caderno, disse olhando-me por cima dos óculos: - É só o que podemos fazer por enquanto. Só trabalhamos em consignação.

Como eu continuasse sem entender, era natural que mostrasse espanto.

- Essa tem sido a nossa norma - disse ele defensivamente. - Foi traçada pelos fundadores, e eu não vejo vantagem em modificá-la. Se o senhor não está de acordo... - fez um gesto que tomei como significando que eu poderia levar a mercadoria de volta. (VEIGA, 2000, p. 119-120, grifos nossos)

Esse diálogo traça as últimas conversas entre os personagens quando, por fim, o visitante pergunta ao vendedor o porquê de ele não se desfazer dos sacos de problemas em excesso na loja, ao que o vendedor responde que se livrar dos sacos poderia comprometer as pessoas: “[...] não sei onde iremos parar." (VEIGA, 2000, p. 120). A última pergunta que o visitante faz nos mostra o zelo do vendedor em relação aos desastres que a violação dos sacos poderia causar: 
Perguntei o que aconteceria se um daqueles sacos se rasgasse e derramasse a mercadoria. O velhinho olhou-me apavorado, bateu três vezes com os nós dos dedos do balcão.

- Brinca não. Seria um desastre. Todo mundo teria que fugir com a roupa do corpo.

- Sério assim?

- Então! O meu amigo parece que ainda não entendeu. Isso espalha como jiquitaia, entra pelos poros, inutiliza a pessoa. Só escapam os que têm couraça natural invisível, os chamados cascamorros. Fale em derramar isso não, nem brincando. Que horror! Não ganhei para o susto. (VEIGA, 2000, p. 121)

Murilo Rubião e José J. Veiga possuem formas muito peculiares de sinalizarem, através de situações absurdas, o nosso real mundo. No conto "Os Cascamorros" existe um cuidado em isolar os sacos de lixo de forma que eles não destruam as pessoas. Há “[...] a incrível possibilidade de esvaziar um saco de problemas e as consequências serem fatais para todo o mundo, exceto para esses desconhecidos Cascamorros." (SOUZA, 1990, p. 110). Ainda que tenha sido criticado ou visto com curiosidade e arrogância pelo visitante por conta de sua excentricidade, o dono da loja ensaca e guarda problemas de forma que eles não atinjam aqueles que não possuem “couraça natural invisível.” (VEIGA, 2000, p. 121). Em "O lodo", diante da recusa em ser atendido pelo médico, a situação de Galateu se agrava, a ponto de ele não conseguir mais sair de casa. Com a saúde cada vez mais precária, debilitado e hostilizado pela irmã, Epsila, que se mudara com o filho para o apartamento do irmão para cuidar de sua saúde, o conto termina com a realização do sonho que Galateu tivera:

Exalava um odor fétido da pústula. O mentecapto não se importava, entretido em dar cabriolas na extremidade do aposento. A mãe, comprimindo as narinas com os dedos, abriu a janela. Como persistisse o mau cheiro, abandonou o quarto e só regressou ao ouvir tocar a campainha do telefone. Disse algumas palavras em voz baixa e passou o fone ao irmão, que não conseguiu retê-lo nas mãos. Ela veio em seu auxílio. Segurou o receptor para o enfermo, que mal ouvia e custava a entender o que lhe diziam. Em resposta, apenas balbuciou:

- Venha. - Uma baba de sangue escorreu pelos cantos da boca.

Um quarto de hora depois aparecia o doutor Pink. Circunspecto, abriu o paletó do pijama de Galateu e com o bisturi, retirado da valise, limpou as pétalas da ferida. Epsila, a um sinal do médico, aproximou-se e ambos se debruçaram sobre o corpo do moribundo, enquanto este esboçava imperceptível gesto de asco. (RUBIÃO, 1998, p. 244)

Questionado a respeito de sua escrita, em que o fantástico poderia ser uma maneira de expressar uma realidade política ou social em termos disfarçados, Rubião enfatiza ser impossível 
qualquer tipo de literatura que não seja de abordagem social, de participação e de engajamento. Não no sentido de o escritor se transformar em militante de qualquer doutrina, seja nazista, seja comunista ou pretensamente democrática. O escritor pode tomar sua posição sem ter que militar e sem ter que participar em ação de guerrilha. Cada um tem na sociedade a sua função. Uns lutam nas selvas e outros escrevem. E talvez sejam esses os importantes, muito mais importantes do que os guerrilheiros. (Rubião apud LOWE, 2012, s/p)

Também José J. Veiga corrobora com tal pensamento ao ser questionado a respeito de sua escrita ser considerada como parte do "realismo fantástico". O autor cita uma ocorrência por ele lida à época em um jornal, que apontava que no Rio de Janeiro os casos de lepra estavam aumentando assustadoramente - doença conhecida na Europa durante a Idade Média e que em pleno século XX ainda ocorria no Brasil. Esse exemplo citado pelo autor o faz questionar sobre o fantástico em suas obras: “Ora, isso é que é fantástico, no mundo de hoje acontecer esse tipo de coisa. Um mundo fantástico? É o nosso mundo." (Veiga apud PRADO, 1989, p. 29).

\section{Considerações finais}

Luiz Costa Lima (1986, p. 70) em Sociedade e discurso ficcional assim observa a função da literatura desenvolvida no século XX: "Uma função negativa e incômoda, não mais corroboradora dos belos sentimentos". A negatividade da qual Lima se refere fundamenta-se no fato de que não há como, no mundo contemporâneo, atribuirmos determinados papéis ou funções, como função estética, não só à literatura como às artes no geral. Ainda citando Lima (1986, p. 71), a literatura “[...] não é legisladora de coisa alguma, como pretendia o romântico inglês; é apenas aquilo que, de seu comércio com o concreto, propõe dúvidas e questões [...]". Ao analisarmos os contos "Os Cascamorros" e "O lodo" vimos que estas questões, imbuídas pelo inaudito ou insólito, apontaram para nossa realidade, em especial a realidade da América Latina, que conforme a história nos mostra, é recheada de opressão, tiranias, desajustes sociais, constantes crises na economia e política.

Desenvolvemos, de certa forma, o desejo de transcender um outro mundo, no qual pudéssemos garantir a realização de nossos sonhos e utopias, e aqui a vertente do Fantástico, Realismo Mágico, possibiliou que as narrativas latino-americanas, em especial durante as décadas de 50 a 70 do século XX, apresentassem em seus projetos sociais nossos reais anseios

\footnotetext{
${ }^{1}$ Depoimento concedido pelo autor aos pesquisadores do Instituto de Estudos da Linguagem da UNICAMP em outubro de 1987. As conversas e depoimentos foram organizados por Antonio Arnoni Prado e publicados na obra Atrás do mágico relance: uma conversa com J. J. Veiga. Campinas: Editora da UNICAMP, 1989.
} 
e aspirações: "A história do romance latino-americano, desde suas primeiras formulações, esteve acompanhada por aspirações renovadoras que se desenvolvem num plano utópico." (CORONEL, 2001, p. 48). O autor ainda enfatiza que: “A busca de um mundo melhor foi, e é, um dos fatores genéticos dessa narrativa." (CORONEL, 2001, p. 48).

Foram esses questionamentos, dúvidas e incertezas que nos instigaram, ao longo deste trabalho, e nos permitiram lançar um olhar com mais acuidade à literatura latino-americana, que em muito contribuiu para confrontar nossa posição frente ao mundo desalinhado e perturbado por conta de problemas de ordens várias. Problemas esses revelados, através de um discurso ficcional, nos contos que foram analisados neste trabalho.

Por fim, imiscuímos às colocações de Lima (1986) algumas observações de Ángel Rama (2008, p. 49), para quem a literatura seria um processo "que se constrói entre a arte e a sociologia”. Podemos notar, inclusive, que o vínculo entre arte e história é muito forte na América Latina: “A literatura na América Latina, em sua interação com a história, ultrapassou os limites da história oficial e, pelas trilhas poéticas [...] contou a história da essência de um povo" (CARDOSO, 2009, p. 34). No caso deste trabalho, vimos que através da vertente do Realismo Mágico, lojas que vendem problemas ou doenças misteriosas podem nos fazer pensar a respeito de nossa essência e da própria condição humana: transitória, finita e muitas vezes limitada.

\section{Referências}

BIRMAN, J. Entre cuidado e saber de si. Sobre Foucault e a Psicanálise. Rio de Janeiro: Relume Dumará, 2000.

CARDOSO, J. B. Uma mapa da história sobre o mapa da ficção. Goiânia: Ed. da UCG, 2009.

CHIAMPI, I. O realismo maravilhoso: forma e ideologia no romance hispano-americano. São Paulo: Perspectiva, 2008.

CORONEL, R. R. Um diálogo com a história: romance e revolução. In: CHIAPPINI, L.; AGUIAR, F. W. de (Org.). Literatura e História na América Latina. 2. ed. Tradução de Joyce Rodrigues Ferraz, Ivone Daré Rabello e Sandra Vasconcelos. São Paulo: Editora da Universidade de São Paulo, 2001. p. 48-73.

DELEUZE, G.; GUATTARI, F. 1440 - O Liso e o Estriado. In: DELEUZE, G., GUATTARI, F. Mil platôs: capitalismo e esquizofrenia. São Paulo: Editora 34, 1997. p. 157-189.

ESTEVES, A. R.; FIGUEIREDO, E. Realismo mágico e realismo maravilhoso. In: FIGUEIREDO, E. (Org.). Conceitos de literatura e cultura. Niterói: EdUFF; Juiz de Fora: EdUFJF, 2010. p. 393-414.

FOUCAULT, M. Microfísica do poder. Rio de Janeiro: Graal, 1979. 
FOUCAULT, M. Resumo dos cursos do Collége de France (1970-1982). Consultoria Roberto Machado. Rio de Janeiro: Jorge Zahar, 1997.

LAPLANTINE, F.; TRINDADE, L. S. O que é imaginário. São Paulo: Brasiliense, 2003.

LIMA, L. C. Sociedade e discurso ficcional. Rio de Janeiro: Guanabara, 1986.

LUCAS, F. A arte do conto em Murilo Rubião. In: Crítica. (site Murilo Rubião - 2012). Disponível em:

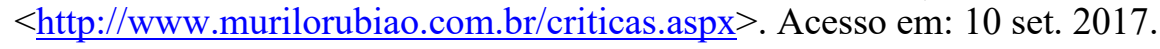

PRADO, A. A. (Org.). Atrás do mágico relance: uma conversa com J. J. Veiga. Campinas: Editora da UNICAMP, 1989.

RAMA, Á. Literatura, cultura e sociedade na América Latina. Belo Horizonte: UFMG, 2008.

RUBIÃO, M. O lodo. In: Contos reunidos. São Paulo: Ática, 1998. p. 235-244.

RUBIÃO, M. Entrevista com Murilo Rubião. In: . Murilianas (site Murilo Rubião - 2012). Disponível em: $<$ http://www.murilorubiao.com.br/entlowe.aspx $>$. Acesso em: 10 set. 2017.

SOUZA, A. P. de. Um olhar crítico sobre nosso tempo. Uma leitura da obra de José J. Veiga. Campinas: Editora da UNICAMP, 1990.

TODOROV, T. Introdução à literatura fantástica. Tradução de Maria Clara C. Castello. 3. ed. São Paulo: Perspectiva, 2008.

VEIGA, J. J. Os Cascamorros. In: Os melhores contos de J. J. Veiga. Seleção de J. Aderaldo Castello. São Paulo: Global, 2000. p. 117-121 
